UNIVERSIDADE DE SÃO PAULO

Faculdade de Filosofia, Letras e Ciências Humanas

Departamento de História

Programa de Pós-Graduação em História Social

\title{
DA MÚSICA FOLCLÓRICA À MÚSICA MECÂNICA. \\ UMA HISTÓRIA DO CONCEITO DE MÚSICA POPULAR POR INTERMÉDIO DE MÁRIO DE ANDRADE (1893-1945)
}

Versão corrigida

São Paulo

2012 
UNIVERSIDADE DE SÃO PAULO

Faculdade de Filosofia, Letras e Ciências Humanas

Departamento de História

Programa de Pós-Graduação em História Social

\section{DA MÚSICA FOLCLÓRICA À MÚSICA MECÂNICA. UMA HISTÓRIA DO CONCEITO MÚSICA POPULAR POR INTERMÉDIO DE MÁRIO DE ANDRADE (1893-1945)}

Juliana Pérez González

Dissertação apresentada ao Departamento de História da Faculdade de Filosofia, Letras e Ciências Humanas da Universidade de São Paulo para obtenção do grau de Mestre em História Social.

\section{Versão corrigida}

Orientador: Prof. Dr. José Geraldo Vinci de Moraes 
Autorizo a reprodução e divulgação total ou parcial deste trabalho, por qualquer meio convencional ou eletrônico, para fins de estudo e pesquisa, desde que seja citada a fonte.

Catalogação na Publicação Serviço de Biblioteca e Documentação Faculdade de Filosofia, Letras e Ciências Humanas da Universidade de São Paulo

P438m

Pérez González, Juliana

Da música folclórica à música mecânica. Uma história do conceito de «música popular» por intermédio de Mário de Andrade (1893-1945) / Juliana Pérez González ; orientador José Geraldo Vinci de Moraes.

São Paulo, 2012.

276 f. CD.

Dissertação (Mestrado)- Faculdade de Filosofia, Letras e Ciências Humanas da Universidade de São Paulo. Departamento de História. Área de concentração: História Social.

1. Música Popular. 2. Conceitos. 3. Mário de Andrade. 4. Historiografia. 5. História da música. I. Moraes, José Geraldo Vinci de, orient. 


\section{AgRADECIMENTOS}

Quando se estuda em um país estrangeiro, são muitas as pessoas a quem se quer agradecer, pois cada ajuda recebida torna-se vital. Em primeiro lugar, agradeço ao programa PEC-PG, do governo brasileiro, cujo fomento torna possível a vinda de pessoas da América Latina, África e Ásia ao Brasil para a realização de estudos de pós-graduação em suas universidades, pois com a bolsa de estudos concedida, conseguimos nos deslocar para o Brasil e cumprir as atividades acadêmicas. Para esta pesquisa, também foi importante o auxílio econômico e humanos proporcionado pelo Cuban Research Institute da Universidad Internacional de Florida, por intermédio da Diaz Ayala Travel Grant, para consultar a coleção musical Diaz-Ayala. Devo agradecer, particularmente, o entusiasmo de sua bibliotecária, Verónica González.

Agradeço especialmente a meu orientador, Prof. Dr. José Geraldo Vinci de Moraes, que leu meu primeiro e-mail, encontrou motivos para confiar em mim e me deu a oportunidade de me formar sob sua orientação. A leitura atenta e paciente de todos os meus textos, suas sugestões, seu acompanhamento ao longo do processo, suas chamadas de atenção, o interesse pelas coisas de que eu poderia necessitar em um país novo, além da discussão e guia no amadurecimento das colocações foram a base sólida sobre a qual este escrito foi construído.

À amorosa Profa. Dra. Flávia Camargo Toni, agradeço por suas aulas e seus braços abertos toda vez que procurei por sua ajuda; este trabalho beneficiou-se de sua sapiência acadêmica e de sua bondade espiritual. Com a mesma amabilidade, seus alunos, Luciana Barongeno e Mauricio Teixeira, também compartilharam seus conhecimentos sobre o pensamento de Mário de Andrade e sugeriram a leitura de textos que se mostraram esclarecedores. Luciana leu o rascunho, escrito para meu exame de qualificação, e fez sugestões muito pertinentes.

Da mesma forma, este trabalho beneficiou-se dos ensinamentos da Profa. Dra. Sara Albieri e do Prof. Dr Elias Saliba, que em suas aulas abriram minha mente 
com leituras e interpretações inovadoras. Também os professores Dr. Marco Napolitano e Dr. Paulo Castagna, que participaram da minha banca de qualificação, ajudando-me a vislumbrar novas possibilidades na pesquisa.

Pela boa qualidade do português devo agradecer ao trabalho amigável de Carmem Cacciacarro, quem mostrou disposição para trabalhar com um curto prazo na tradução do texto original em espanhol. Também agradeço a Paula Martins de Souza por seu profissionalismo na revisão do escrito em português: suas indicações foram pertinentes para melhorar a clareza do texto. O tempo dedicado a esclarecimento de minhas dúvidas foi de inestimável ajuda. O interesse constante de María Mercedez Ortíz (Nana) na pesquisa e no processo de escrita foi estimulante e agradeço sua revisão do resumo em inglês.

A Priscila de Carvalho e a Osvaldo Medeiros, os competentes secretários do Departamento de História, que sempre responderam a minhas dúvidas mais básicas e não economizaram esforços em me ajudar a cumprir com os requisitos exigidos pela Polícia Federal para manter "em dia" meus papéis de estrangeira.

A Giuliana Lima, companheira de mestrado e de orientador, agradeço pela alegre amizade e por ter me permitido compartilhar as habituais angústias estudantis. Não menos importantes foram as conversas e a amizade de Lígia Conti, Silvia de Ambrosis Pinheiro Machado e Max Christian Frauendorf, meus queridos colegas e amigos do primeiro semestre, que se converteram em minhas melhores boas-vindas ao território brasileiro. O apoio de Analia Cherniavsky e Gabriel Rezende, que, desde Campinas, ofereceram-me sua mão amiga em tudo de que precisei. Também agradeço a Mónika Winckler e sua família que encheram de calor familiar meus dias em São Paulo.

A meus companheiros de "moradia", onde desfrutei da cultura brasileira, adquirindo maior carinho pelo país que me acolheu. A Ana, a portuguesa, Fábio, Natasha, Márcio, Francisco, Danilo, Bruno, Carlos, Jorge, Aymara, Zélia, Antônio e todas as pessoas que passaram por aquela casa grande de quartos pequenos.

A força que é necessária para viver em um país novo, devo a minha família e a meu noivo, Ricardo Becerra Enríquez que, um tempo depois, aprendeu português e veio ao Brasil para compartilhar comigo as vivências do dia-a-dia. Seu apoio e 
preocupação com o presente trabalho foram absolutamente generosos, e suas múltiplas ajudas foram profundamente motivadoras. Devo agradecer, particularmente, todo o empenho que dedicou à recuperação dos dados do disco rígido do meu computador.

A minha mãe, María Stella González de Pérez, a meu pai, Jorge Pérez Botía, e a minha irmã, Camila Pérez González, devo tudo o que tenho e sou. Seu amor e seus abraços de boas-vindas sempre que estive em meu país foram o combustível que me fez regressar revitalizada. A generosidade de meu pai não tem limites, e graças a ela pude visitá-los em várias ocasiões e me sustentar em São Paulo uma vez terminada minha bolsa de estudos. A presença constante de minha mãe por meio do Skype e do MSN para me ajudar em tudo de que precisei, compartilhando comigo sua experiência como pesquisadora e seu amor pela música, foram fundamentais; além disso, foram auxílios definitivamente inestimáveis sua assessoria para organizar uma tabela temática viável — quando perdi a informação de meu computador —, sua tradução dos textos em francês e a leitura do rascunho do documento da qualificação O cuidado que minha irmã deu a meus pais durante esses anos e sua boa disposição diante de todas as necessidades familiares foram o melhor suporte que poderia receber para terminar este trabalho. 


\section{RESUMO}

A partir da revisão da obra musicológica do intelectual brasileiro Mário de Andrade (1893-1945) foram estudadas as características do conceito de música popular. Vislumbraram-se as complexidades que intervieram na construção desse conceito polissêmico por meio da comparação entre o pensamento musical de Mário de Andrade e de alguns colegas latino-americanos.

Este pesquisa diferencia entre o conceito de música popular, herdeiro da visão de mundo do romantismo oitocentista, e o surgimento de outro significado relacionado com a música que circulava nas cidades e que era difundida pelos modernos meios de comunicação eletrônicos. Com o passar do século XX, esse novo tipo de música popular urbana distanciou-se cada vez mais da noção romântica de música popular, e contribuiu na criação de tensões no interior do conceito. Os escritos de Mário de Andrade, sistemáticos e tematicamente variados, permitem ilustrar essas complexidades na construção de seu próprio conceito de música popular.

Esta dissertação leva ao campo da historiografia musical latino-americana as discussões e debates historiográficos posteriores à década de 1970 acerca da construção da cultura popular derivada de uma elite acadêmica.

PAlaVRAS-Chave: Música popular, Conceito, Mário de Andrade, Historiografia, História da música, América Latina.

\section{ABSTRACT}

By reviewing the musicological work of the Brazilian intellectual Mário de Andrade (1893-1945), I research the meaning and characteristics of the concept of popular music in Brazil. I examine the construction of this polysemous concept through the comparison of de Andrade's thinking about music with the one of some of his Latin American colleagues.

My work differentiates between a meaning of popular music, heir of the romantic worldview of the nineteenth century, and the appearance of a different meaning related to urban music disseminated by the new electronic communication devices, in the twentieth century. On time, this new kind of popular urban music distanced itself from the romantic concept of popular music and created tensions 
within the concept itself. Mario de Andrade's essays, systematic and thematically varied, illustrate the concomitant complexities in the construction of his popular music concept.

This monograph takes the post-1970 historiographical discussions and debates about the construction of the popular culture, made by an academic elite, to the musical historiography field in Latin America.

KeYwords: Popular music, Concept, Mário de Andrade, Historiography, History of music, Latin America.

\section{RESUMEN}

A partir de la revisión de la obra musicológica del intelectual brasileño Mário de Andrade (1893-1945) se estudiaron las características que tuvo el concepto de música popular en Brasil. Se examinó la construcción de este concepto polisémico a través de la comparación entre el pensamiento musical de Mário de Andrade y de algunos colegas latinoamericanos.

Este trabajo diferencia entre un significado de música popular, heredero de la visión de mundo romántica decimonónica, y la aparición de otro significado relacionado con la música que circulaba en las ciudades y era difundía por los modernos medios de comunicación electrónicos. Con el devenir del siglo XX ese nuevo tipo de música se distanció de la noción romántica de música popular, y contribuyó a la creación de tensiones en el interior del concepto. Los escritos de Mário de Andrade, sistemáticos y temáticamente variados, ilustran estas complejidades en la construcción de su propio concepto de música popular.

Esta monografía llevó al campo de la historiografía musical latinoamericana las discusiones y debates historiográficos posteriores a la década de 1970 sobre la construcción de la cultura popular, hecha por una élite académica.

Palabras Claves: Música popular, Concepto, Mário de Andrade, Historiografía, Historia de la música, Latinoamérica. 


\section{SUMÁRIO}

Introdução. .11

"Na minha casa da rua Lopes Chaves": a biblioteca musical latino-americana

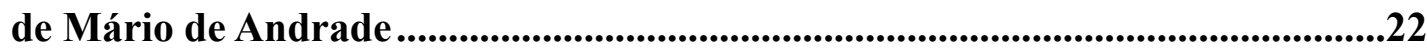

1 Os escritos musicais de Mário de Andrade ..................................................25

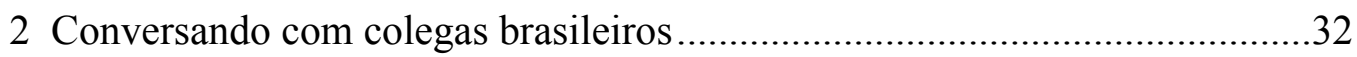

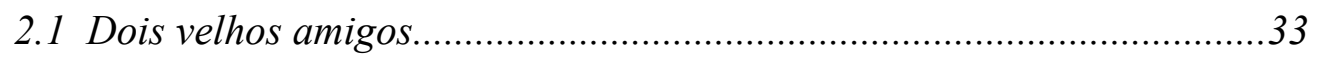

2.2 Um jovem músico pesquisador...........................................................4 41

2.3 A admiração de uma mulher .................................................................46

3 Mário de Andrade e o ambiente latino-americano ........................................52

3.1 Francisco Curt Lange e a primeira rede musicológica ............................53

3.2 Da Colombia, Emirto de Lima ..............................................................61 61

3.3 Do México, Vicente T. Mendoza ...............................................................66

3.4 De Cuba, Eduardo Sánchez de Fuentes e Fernando Ortíz ..................... 70

3.5. Do Chile, Carlos Lavín e Domingo Santa Cruz...................................... 75

3.6. Carlos Vega e os silêncios argentinos..................................................... 79

“Não sou folclorista não": As vozes do romantismo na construção do conceito música popular ..........................................................................................................85

1 Música popular na América Latina oitocentista: ausência de um conceito?...87

2 Entre o popular e o erudito ..........................................................................98

Mário de Andrade entre o ganzá e o piano..................................................107

3 A música popular e o folclore .....................................................................124

O folclore musical em Mário de Andrade ..................................................132

4 As cidades e a música popular .......................................................................143

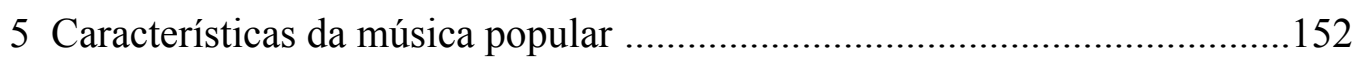

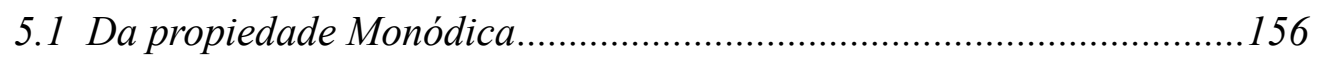

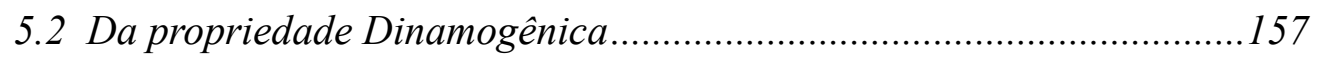

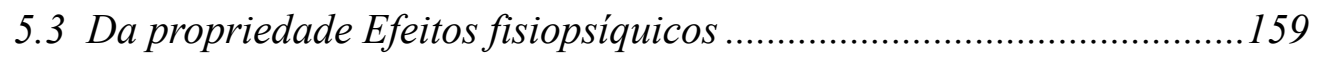

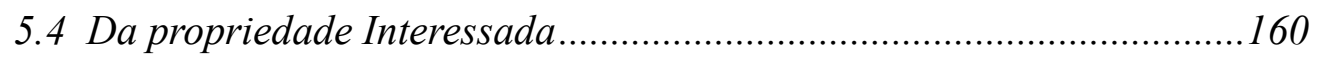

5.5 Das propriedades Coletiva e anônima ................................................... 161

5.6 Da propriedade Memorizável............................................................... 163

"Carne para alimento de rádios e discos". Sons da cultura urbana moderna e o conceito de música popular.

.168

1 “Os técnicos norte-americanos que vieram para cá se desnortearam": Mário de Andrade e os discos 168 
2 Revolução tecnológica: disco, rádio e cinema............................................188

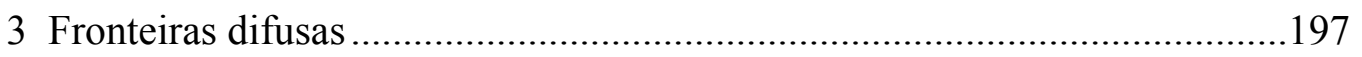

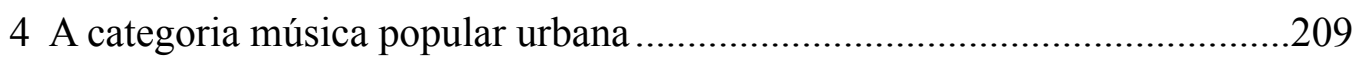

5 Prevenção e desprezo pela música popular urbana.......................................217

A música popularesca de Mário de Andrade.................................................226

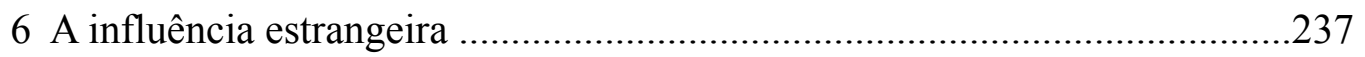

7 Processos de folclorização e popularização..................................................244

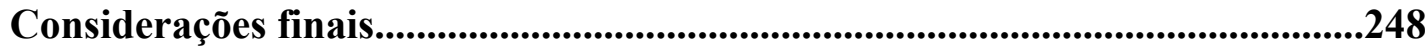

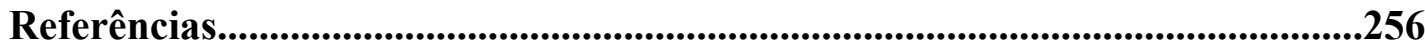

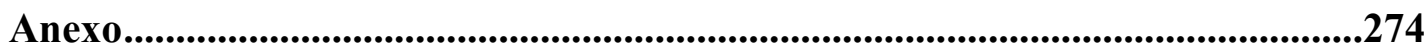




\section{INTRODUÇ̃̃O}

Já há algum tempo a historiografia convencionou que o historiador usa tanto fontes documentais quanto conceitos para construir sua visão do passado. Em muitas ocasiões, saber quais fontes foram usadas é mais fácil do que reconhecer seus conceitos pois, geralmente, estes últimos são usados como um fio tênue e transparente que costura as "operações mentais" do historiador e ocupa o avesso de seu bordado. O reconhecimento desse fio conceitual não é intrincado somente para o leitor ocasional: também o próprio pesquisador, algumas vezes, interioriza e aplica de forma inconsciente as ferramentas conceituais, correndo o risco de ficar alheio a suas qualidades.

Os conceitos servem ao historiador para dar forma às suas interpretações do passado; também guia sua atenção para fontes específicas; fornece uma leitura e interpretação singulares; segue algumas pistas e despreza outras; traça relações entre eventos; sustenta sua análise particular, etc. Não obstante, em que pese a sua importância, não existe uma caixa de ferramentas conceitual única nem unívoca, mas sim conceitos que se mantêm flutuando, em constante construção, sempre mediados pelas ideologias de cada época e lugar. O historiador filia-se a alguns conceitos e consciente ou inconscientemente - acaba por empregá-los para tecer suas interpretações do passado. Segundo esse tipo de análise historiográfica, faz parte do ofício do historiador adestrar-se no reconhecimento, manejo e aplicação de seus fios conceituais, a fim de respeitar a distância que o separa do passado, bem como ser consciente de sua posição histórica e ideológica e não outorgar a homens antigos pensamentos que lhes sejam alheios ${ }^{1}$.

Por ora, interessa ressaltar que esses conceitos com os quais a história se constrói são mutáveis porque guardam uma relação íntima com as formas de

1 Ver: Marrou, Herni-Irenee. Do conhecimento histórico. [1954] São Paulo: Martins Fontes, 1975 e Veyne, Paul. "A história conceitual." In: Jacques Le Goff, et al. (ed.), História: Novos Problemas, Rio de Janeiro: Francisco Alves, 1995. 
pensamento de cada época e permeiam sua historiografia. Apesar disso, alguns conceitos se construíram a si mesmos como contínuos e universais sem sê-lo necessariamente. Suas próprias definições os envolveram em uma aura de verdade que os fez passar como próprios da natureza humana, quando, na realidade, faziam parte de visões de mundo ou de ideologias particulares, que estavam profundamente arraigadas e cuja veracidade não era questionada ${ }^{2}$. Tudo parece indicar que o conceito popular teve características de universalidade sob a supremacia do romantismo e, por esse motivo, teve que esperar o aparecimento das primeiras críticas aos postulados românticos para que também começasse a passar por uma revisão teórica.

O romantismo definiu os produtos populares como pertencentes a uma esfera cultural autônoma, independente e coerente. Análise posteriores, do século XX, entenderam o popular como um sistema cultural de resistência diante da cultura dominante, e outros pontos de vista o tomaram por um sistema sem criatividade, produto das imposições da classe dominante. Aproximadamente a partir de finais da década de 1970, quando a disciplina histórica viveu uma renovação temática e teórica, surgiu um marcado interesse pelo estudo da chamada cultura popular e, com ele, um intercâmbio teórico sobre sua delimitação e suas implicações no exercício do historiador ${ }^{3}$. Nas últimas décadas do século $\mathrm{XX}$, vários autores - dentre os quais podem ser mencionados Michel de Certeau e seus alunos Jacques Revel e Roger Chartier - refletiram sobre a maneira como os historiadores entenderam a cultura popular, propondo novos elementos de análise que apontam para a caracterização da categoria como sendo um grupo de práticas plurais, dialéticas e de intercâmbio contínuo $^{4}$. Através das diversas interpretações do popular, feitas desde fins do século XVIII e até a atualidade, chama a atenção o fato de se tratar de um conceito profundamente teórico, posto em relação com o conceito de erudito ou culto, cujas particularidades estiveram mediadas pela historicidade do pensamento ocidental.

O presente trabalho partiu desse tipo de observação para fazer uma análise histórica do conceito popular no campo da música e sua historiografia. Tudo parece

\footnotetext{
${ }^{2}$ Marrou. Do conhecimento histórico. [1954].

${ }^{3}$ Burke, Peter. O que é a história cultural? [2004] Rio de Janeiro: Jorge Zahar Editores, 2005.

${ }^{4}$ Moraes, José Geraldo Vinci de. "Modulações e novos ritmos na oficina da História." Revista galega de cooperación científica iberoamericana. no. 11 (2005).
} 
indicar que, nos discursos sobre música, a categoria música popular foi cunhada como produto do chamado descobrimento do popular no final do século XVIII na Europa $^{5}$. Desde então, a expressão tem sido usada pelos pesquisadores do campo musical, primeiro, nos estudos de folclore e, agora, nos estudos da musicologia. Nas últimas décadas, as pesquisas sobre a música popular urbana têm levado os musicólogos à busca da consolidação de um conceito de música popular que contemple a música popular midiática. Mas, em geral, as tentativas de definição dessa categoria musical concordam que se trata de um termo complexo, dada sua ligação com aspectos históricos e ideológicos, e não só musicais ${ }^{6}$.

Este trabalho não se propôs a chegar a uma definição de música popular, mas simplesmente refletir, por meio de um olhar histórico, sobre uma parte das complexidades que impediram a musicologia de chegar a um acordo sobre o seu significado. Alimentada por algumas das reflexões que a historiografia atual tem feito sobre o popular, esta pesquisa usou uma metodologia histórica para identificar certos elementos que contribuíram para o processo de construção do conceito de música popular em si.

Em primeiro lugar, partiu-se de corroborar que, desde o surgimento do conceito música popular, e ao longo do tempo, o uso que se tem feito dele no pensamento musical é basicamente taxativo. Atualmente, esse termo parece que uma das categorias mais frequentes no vocabulário. Não obstante, quando se tenta determinar que tipo de música ele encerra, encontram-se peças que, tomadas lado a lado, parecem bastante diferentes. Por exemplo, são facilmente classificadas como populares a música dos grupos The Beatles e Paralamas do Sucesso; mas também há quem enquadre sob a mesma categoria as melodias de bumba meu boi que foram gravadas pela Missão de Pesquisas Folclóricas em São Luiz (Maranhão), ou ainda uma canção aprendida por tradição oral em São Basílio de Palanque, em um

\footnotetext{
${ }_{5}^{5}$ Burke, Peter. Cultura popular na idade moderna. [1978] São Paulo: Companhia das Letras, 1989 e Ortiz, Renato. Cultura popular: românticos e folcloristas. São Paulo: Programa de Estudos Pós-Graduados em Ciências Sociais Pontifícia Universidade Católica de São Paulo, 1985.

6 Uma síntese do problema está em: Middleton, Richard e Manuel, Peter. "Popular Music." Grove Music Online. Oxford Music Online, 2010.

Para o contexto latino-americano, pode-se ver: Aharonián, Coriún. "Carlos Vega y la teoría de la música popular. Un enfoque latinoamericano en un ensayo pionero." Revista Musical Chilena. v. 51, no. 188 (1997) e González, Juan Pablo. "Musicología popular en América Latina: síntesis de sus logros, problemas y desafíos." Revista Musical Chilena. v. 55, no. 195 (2001).
} 
quilombo próximo à costa atlântica colombiana. Diz-se, até, que peças muito conhecidas do repertório erudito também poderiam ser consideradas populares, como é o caso da bagatela para piano solo de Ludwing van Beethoven "Para Elisa" ou da ária "La donna è mobile" da ópera Rigoletto de Giuseppe Verdi.

Como se vê, música popular pode ser inventariada em mais de uma categoria pertencente a uma mesma taxonomia, o que é um paradoxo em si, mas que tem uma explicação histórica: a pluralidade de significados que encerra é reflexo das tensões irresolutas que alimentaram a construção de seu significado. Para compreender essa construção, levou-se em conta que os diferentes sistemas de classificação das coisas, adotados pelos humanos, estão sujeitos à maneira como seu meio é percebido, meio que no âmbito musical estudado foi particularmente ambíguo.

Além disso, e de acordo com a história dos conceitos, a polissemia de certos vocábulos é produto de uma construção histórica na medida em que suas definições transformam-se de acordo com certos contextos históricos, derivando na composição de uma gama de significados. Portanto, ao trabalhar com vocábulos polissêmicos, o historiador facilmente se verá envolvido com sua historicidade e, por isso, Reinhart Koselleck sustentou a ideia de que uma das funções primárias da história dos conceitos era “...traduzir significados lexicais em uso no passado para a nossa compreensão atual"’7.

Sem pretender fazer uma tradução entre o passado e o presente do conceito música popular, o objetivo deste trabalho foi basicamente estudar o processo de construção que o conceito sofreu entre fins do século XIX e primeira metade do século XX, na América Latina, por intermédio do pensamento musical de Mário de Andrade (1893-1945) e de alguns de seus colegas. De forma lateral, esta pesquisa introduz na historiografia musical latino-americana uma leitura que considera música popular como um conceito teórico já polissêmico, que nasceu em um contexto histórico particular e cujo significado sofreu transformações em relação a seu meio, até se configurar como esse conceito plural e indefinido dos dias de hoje.

7 Koselleck, Reinhart. "História dos conceitos e história social." [1979] Futuro passado. Contribuição à semántica dos tempos históricos, Rio de Janeiro: Contraponto / PUC-Rio, 2006, p. 104. 
Como alvo de esta investigação, privilegiou-se o período durante o qual o escritor brasileiro viveu porque durante essas cinco décadas (1893-1945) o vocábulo música popular começou a sofrer algumas de suas mais notórias transformações, ocasionadas pela influência do romantismo, do modernismo e da nascente cultura urbana daqueles anos. Além disso, as contribuições de Mário de Andrade para o conhecimento musical de seu país foram decisivas para a constituição do pensamento de seus contemporâneos e das gerações seguintes. Por essa razão inferiu-se que seu manejo do conceito também influenciou a configuração desse vocábulo no ideário brasileiro e, talvez, latino-americano.

Desde as últimas décadas do século XIX começou a se formar um pequeno grupo de músicos na América Latina que, assim como ocorreu em outros ambientes artísticos, também foi incitado pelo nacionalismo. Dado o estatuto proeminente das questões nacionais no pensamento artístico, esse grupo foi levado a discorrer sobre a música de seus meios e a se ocupar do estudo de sua história, tendo em vista a legitimação de sua riqueza cultural. Entre esses músicos estava Mário de Andrade, que partiu do mesmo interesse de seus colegas e, em São Paulo, uma das cidades cosmopolitas da época, fez um trabalho sistemático e rico de reflexões sobre seu meio musical específico. Esses autores mantiveram-se relativamente isolados em seus contextos nacionais, mas, graças a iniciativas como a do alemão radicado no Uruguai, Francisco Curt Lange, e à correspondência que Mário de Andrade manteve com colegas e amigos, é possível reconstruir certo intercâmbio entre determinados autores desse grupo.

Naquele ambiente intelectual latino-americano de começo do século XX, que, em geral, era incipiente, não houve uma discussão explícita sobre o que era música popular. Embora, aqueles que fizeram uso do conceito adotaram definições implícitas e "temperadas" pelas particularidades de seus contextos, é possível considerar que, na maioria das vezes, o vocábulo foi tacitamente entendido como uma noção de "ambição propriamente universal" — segundo a tipologia feita por Herni-Irenee Marrou dos conceitos usados pelos historiadores ${ }^{8}$-; ou seja, que, para os autores estudados, o conceito música popular era associado a um tipo de música

${ }^{8}$ Marrou. Do conhecimento histórico. [1954] pp. 131-150. 
considerada como imanente à própria natureza humana e por todos conhecida. Desde esse ponto de vista, era de se esperar que a maioria dos escritores considerarem improdutivo levantar argumentações sobre o significado do vocábulo, dada sua aceitada "universalidade". Por esse motivo, a história que ora se apresenta foi construída sobre interpretações sub-reptícias desse conceito, advindas de um grupo de escritores, em geral pioneiros da historiografia musical latino-americana.

Mário do Andrade, bem como a maioria dos autores consultados teve algum nível de formação acadêmica. Por meio do estatuto obtido com sua formação, lograram publicar seus textos e presentá-los à comunidade letrada, pelo qual são identificados como sendo um tipo de elite intelectual. A linguagem que este grupo usou em seus escritos é considerada como registro culto da linguagem, diferenciando-se da linguagem cotidiana dos outros grupos sociais, o que fez com que, tacitamente, esta pesquisa se visse limitada ao estudo de um conceito de música popular manejado pela classe oposta: a classe erudita. Conforme afirmou Roger Chartier, a "cultura popular é um conceito culto" . Ele teria sido pensado e diagramado no imaginário de um grupo social que se posicionava a uma certa distância do que considerava serem as práticas populares. No dizer de Michel de Certeau, os estudos dos historiadores da cultura popular falam menos sobre o que estudam e mais sobre o que era, para eles, aquela cultura. Nas palavras do historiador francês,

Isto nos remete a uma questão com que deparamos repetidas vezes e à qual é preciso responder: de onde se fala, o que se se pode dizer? Mas também, enfim, de onde falamos nós? O problema torna-se, por conseguinte, imediatamente político, uma vez que coloca em causa a função social - isto é, antes de mais nada repressivo - da cultura erudita ${ }^{10}$.

Por outra parte, a obra musicológica de Mário de Andrade distinguiu-se em dois tipos de textos, principalmente: obras publicadas em vida do autor e obras póstumas. Com o fim de fazer um estudo mais preciso sobre a noção de música popular da primeira metade do século XX, fez-se uma análise minuciosa das obras publicadas em vida, posto que estes foram os textos lidos e discutidos por seus contemporâneos e, consequentemente, os que influíram na construção do conceito de

9 Chartier, Roger. "«Cultura popular»: retorno a un concepto historiográfico." Manuscrits. Revista d'història moderna. no. 12 (1994).

10 De Certeau, Michel. "A beleza do morto." [1980] A cultura no plural, Campinas: Papirus Editora, 1995, p. 80. 
seu tempo. Os escritos editados postumamente por Oneyda Alvarenga e Flávia Camargo Toni, durante a segunda metade do século XX, foram consultados para complementar ideias expostas nos escritos anteriores, mas não foram usados como fontes substanciais ${ }^{11}$.

Também se trabalhou na biblioteca que pertenceu a Mário de Andrade, resguardada e disponibilizada ao público pelo Instituto de Estudos Brasileiros (IEBUSP). Graças a ela, obteve-se uma aproximação das leituras que Mário de Andrade pode ter feito de seus contemporâneos latino-americanos e de certas observações a respeito de seus trabalhos, que deixou manuscritas nas margens de alguns de seus exemplares. Cotejar as ideias expostas em seus escritos com os volumes de sua biblioteca particular alimentou a hipótese sobre o alto grau de conhecimento que o autor paulistano provavelmente teve dos trabalhos de seus colegas. A este trabalho também serviu a consulta do chamado «fichário analítico», que consiste em uma coleção de pequenos papéis manuscritos, organizados em envelopes temáticos, nos quais Mário de Andrade costumava anotar as matérias de seu interesse e os dados bibliográficos dos textos em que achava informação a respeito. Por meio do seu «fichário analítico» foi possível completar as informações recolhidas em sua biblioteca e ter uma ideia dos temas relacionados ao contexto musical latinoamericano que o interessavam e das leituras que fez a seu respeito.

Além disso, através de seu arquivo epistolar — também conservado pelo IEB-USP —, tentou-se identificar que tipo de contato houve entre Mário de Andrade e seus colegas brasileiros e hispano-americanos interessados no estudo da música, para "desempoeirar" indícios dos caminhos pelos quais o conceito eventualmente possa ter andado. De forma marginal, também se recorreu à consulta de alguns dos manuscritos que Mário de Andrade deixou inacabados no momento de sua morte, com o fim de sondar os passos que o intelectual poderia ter seguido. Este exercício

11 Esses livros são: Andrade, Mário de. Danças dramáticas do Brasil. São Paulo: Livraria Martins Editora, 1959; Andrade, Mário de. Música de feitiçaria no Brasil. São Paulo: Livraria Martins editora, 1963; Andrade, Mário de. Os cocos. São Paulo: Liv Duas Cidades - Instituto Nacional do Livro; Fundação Nacional Pró-memoria, 1984; Andrade, Mário de. Melodias do boi e outras peças. São Paulo: Duas Cidades - Brasília INL, 1987; Andrade, Mário de. Introdução à estética musical. São Paulo: HUCITEC, 1995, e Andrade, Mário de. Dicionário Musical Brasileiro, Oneyda Alvarenga, et al. (eds.) Belo Horizonte, Brasília, São Paulo: Oneyda Alvarenga, et al.ial, 1989. 
ofereceu elementos que complexificaram mais o seu conceito de música popular e cujos labirintos não foram conhecidos por seus contemporâneos.

Em última instância, o estudo da obra musical de Mário de Andrade ilustrou algumas das complexidades e soluções que um intelectual da primeira metade do século XX expôs silenciosamente em torno do conceito de música popular. Como afirmou José Miguel Wisnik, o estudo do pensamento do escritor corre o risco de enganar-se com a superficialidade aparente de algumas de suas afirmações taxativas e redutoras, mas em cujo fundo há problemas mais sutis ${ }^{12}$. Tentou-se driblar esse tipo de dificuldade por meio do cotejo contínuo de seus textos, embora o presente trabalho não esteja isento de ter deixado passar desapercebidas algumas dessas sutilezas.

Por outro lado, o conceito de música popular que lentamente foi sendo construído na obra de Mário de Andrade foi esporadicamente comparado a ideias que seus contemporâneos tiveram a seu respeito, particularmente visíveis nas histórias da música do território latino-americano. Nesses escritos, os diferentes autores viram-se na obrigação de distinguir tipos de música para organizar seus relatos históricos, e dentre essas categorias costumavam fazer uso da categoria música popular. Entre finais do século XIX e a primeira metade do século XX, sabe-se que foram escritos 33 textos histórico-musicais de grande fôlego, dos quais oito foram publicados no final do século XIX. Dessas 33 histórias da música, teve-se acesso a 24 delas, cobrindo uma área geográfica mais ou menos ampla. Graças ao trabalho com estes textos, obteve-se um conhecimento superficial das situações musicais de países como México, Guatemala, Cuba, Porto Rico, Venezuela, Colômbia, Equador, Peru, Chile, Argentina e Brasil. Embora seja impossível fazer generalizações sobre o pensamento de cada país, essas histórias ajudaram a contextualizar o que Mário de Andrade escrevia no Brasil.

Outra fonte rica em informação para se captar a mentalidade de uma época são os dicionários monolíngues, os quais refletem parte do pensamento do grupo que

$12 \mathrm{O}$ autor identificou que Mário de Andrade tem “...uma tendência que o escritor em certo momento nega em um nível, retorna em outro, já que sua consciência parece viver subterraneamente as contradições, mesmo quando a proposta de uma ação cultural imediata tende a eliminá-las ou atenuá-las para tentar avançar." (Wisnik, José Miguel. O coro dos contrários: a música em torno da Semana de 22. São Paulo: Livraria Duas Cidades, 1977, p. 105). 
se vale de cada língua. Ao trabalhar com dicionários antigos, teve-se em conta que, no passado, a lexicografia construía esses vocabulários baseando-se em diversas obras impressas que circulavam em seu tempo, quer dizer, os dicionários anteriores ao século XX davam conta do uso da norma culta da linguagem. Em datas mais recentes, tornou-se próprio da lexicografia moderna o interesse pela língua oral, sem fazer distinção do grupo social que a usa, buscando-se complementar a descrição do idioma nos chamados "dicionários de uso". No caso da língua espanhola, foram consultadas as 22 edições do dicionário da Real Academia da Língua Espanhola, publicadas desde 1726 até o presente ${ }^{13}$, e outros dicionários antigos feitos por lexicógrafos espanhóis, como o Tesoro de la lengua española o castellana, de Sebastián de Covarrubias $(1611)^{14}$. No caso do português, o número de trabalhos lexicográficos monolíngues é menor e mais tardio, sendo o primeiro deles elaborado por Antonio de Moraes Silva, brasileiro nascido no Rio de Janeiro e formado em Portugal. Este Diccionario da lingua portugueza de Antonio de Moraes Silva (1 ${ }^{\mathrm{o}}$ edição: 1789 e $2^{\circ}$ edição: 1813) baseou-se no Vocabulário portuguez \& latino do monge Raphael Bluteau (1712-1728), e sua importância como dicionário bilíngue também é grande para a lexicografia portuguesa ${ }^{15}$.

Os dicionários musicais antigos foram outra ferramenta que ajudou a ler o idioma da época. Foram usados três dicionários musicais publicados por autores latino-americanos, dois brasileiros e um colombiano. Estes três dicionários ajudaram a complementar a informação já encontrada nos dicionários antigos monolíngues e a tirar dúvidas durante o processo de leitura das outras fontes.

Por último, trabalhou-se com gravações de músicas produzidas pelas empresas discográficas, registradas em discos de acetato e comercializadas durante a primeira metade do século XX, no território latino-americano. Por um lado, a organização e elaboração do catálogo da coleção de discos de $78 \mathrm{rpm}$ de Mário de Andrade, por parte do Arquivo do IEB-USP, permitiu conhecer parte da música que

\footnotetext{
13 Todas as edições podem ser consultadas on-line na página da Real Academia de la Lengua Española $<$ http://www.rae.es/rae.html $>$.

${ }^{14}$ Disponível na Biblioteca Virtual Miguel de Cervantes <www.cervantesvirtual.com>.

${ }^{15}$ Disponíveis na página web do Instituto de Estudos Brasileiros (IEB) da Universidade de São Paulo <www.ieb.usp.br/online/index.asp>. Ver: Murakawa, Clotilde de Almeida Azevedo. Antonio de Morais Silva: lexicografo da lingua portuguesa Araraquara, SP Laboratorio Editorial da FCL, UNESP, 2006.
} 
circulou em São Paulo e que foi ouviu por esse autor; além disso, por meio das notas que o musicólogo brasileiro deixou nas capas de seus discos, também foi possível conhecer algumas de suas mais secretas impressões sobre a música que escutava. Em virtude de o arquivo do IEB - onde repousa a coleção discográfica - não ter disponibilizado para a escuta da totalidade de seus documentos, recorreu-se ao arquivo sonoro do Instituto Moreira Salles, onde há cópias de vários exemplares pertencentes a Mário de Andrade ${ }^{16}$. Do mesmo modo, e graças à bolsa de estudos de pesquisa outorgada pelo Cuban Research Institute da Universidade Internacional de Miami, teve-se acesso à coleção musical Díaz-Ayala, doada pelo colecionador cubano Cristobal Díaz Ayala à Universidade Internacional de Miami, onde estão conservadas gravações precoces de música de diversos países latino-americanos, especialmente centro-americanos. A escuta das músicas matizou certas interpretações das leituras realizadas no transcurso da pesquisa, e o leitor poderá ouvir algumas das gravações no CD anexo toda vez que o texto o remeter a ele por meio de uma colcheia $(\delta)$ acompanhada do número da faixa.

Uma vez exposta a delimitação de nosso campo de pesquisa, bem como suas fontes, resta apresentar a organização desta dissertação. O presente escrito é composto de três capítulos divididos tematicamente. No primeiro, serão apresentados Mário do Andrade e seus contatos com outros latino-americanos que, como ele, também se ocuparam da escrita sobre música em seus respectivos países. Estes tímidos intercâmbios representam os pilares a partir dos quais, possivelmente, foi tecida a teia intelectual que sustentou a construção do conceito de música popular.

No segundo e terceiro capítulos será feita uma análise internalista dos escritos desse grupo de autores, mantendo como centro os trabalhos de Mário de Andrade. No segundo capítulo será analisado o peso do romantismo na construção do conceito música popular, partido da possível ausência do termo no século XIX, quando os processos de modernização eram incipientes; depois, observar-se-á que, à medida em que o nacionalismo e os estudos de folclore influenciaram o ambiente intelectual e musical, o conceito impregnou-se de uma forte carga romântica.

\footnotetext{
${ }^{16}$ A partir de janeiro de 2012, o Arquivo de IEB - USP tem disponível a escuta de sua coleção discográfica em seu local de atenção a público.
} 
No terceiro e último capítulo será estudada a maneira como, paralelamente, a consolidação das culturas urbanas gerou um novo contexto musical que, somado à acolhida recebida pelos modernos meios eletrônicos de comunicação, originou uma música popular nova, que ameaçou o conceito romântico de música popular, criando, desse modo, tensões no interior desse conceito. 


\title{
"NA MINHA CASA DA RUA LOPES CHAVES": A BIBLIOTECA MUSICAL LATINO-AMERICANA DE MÁRIO DE ANDRADE
}

\begin{abstract}
À casa número 546 da Rua Lopes Chaves, no bairro da Barra Funda, chegaram cartas de muitos lugares do Brasil, da América e da Europa, dirigidas ao cada vez mais famoso escritor Mário de Andrade. Talvez, elas fossem respondidas em seu estúdio, no andar de cima da casa, onde o escritor mantinha obras de arte moderna brasileira, peças de arte religiosa popular, poltronas, cinzeiros e taças de café. Esse era o lugar de trabalho de Mário de Andrade. Ali estava "Manuela", a máquina de escrever na qual datilografou suas publicações, além de canetas, lápis, folhas de papel em branco, envelopes de papel, cadernetas e fichas de menor tamanho que o auxiliavam na hora de organizar suas leituras e ideias. Nas paredes, estavam algumas das estantes em que ele organizou, ao longo do tempo, uma das mais ricas bibliotecas da cidade naquela época. Possivelmente, aquela família já estava familiarizada com os livros do avô, cuja coleção aumentou com os exemplares que Mário de Andrade foi adquirindo e recebendo durante sua vida. O estúdio ficou pequeno, e as estantes da biblioteca saíram para ocupar outros espaços da casa. Com a ajuda de sua irmã, e depois de seu assistente, José Bento Faria Ferraz, os livros foram organizados por grupos temáticos, e a cada um foi atribuído um número que permitia sua localização rápida, de acordo com a sala, a estante e a prateleira onde estava guardado. Em uma esquina de seu estúdio, repousava um harmônio, que Mário de Andrade costumava tocar nas noites de insônia para acalmar os nervos e, embaixo, na sala de visitas, estava o piano em que ele e o irmão mais novo estudaram durante a infância e que, em seus anos maduros, serviu para animar as festas com familiares e amigos ${ }^{1}$.
\end{abstract}

${ }^{1}$ Eu sou trezentos, sou trezentos e cincoenta. Rio de Janeiro: Agir, 2008. 
Neste capítulo, esses livros e cartas que pertenceram a Mário de Andrade serão usados para ilustrar alguns contatos entre ele e um grupo de intelectuais latinoamericanos, com quem compartilhou seu interesse pela pesquisa musical ${ }^{2}$. Embora, o conceito de música popular tenha sido usado pelos intelectuais estudados, nenhum deles debateu seu significado nas cartas. Nas publicações analisadas nos dois capítulos seguintes estão os indícios mais interessantes acerca do conceito. Não obstante, considerou-se importante desempoeirar sua rede de contatos para entrever as relações que esses intelectuais tiveram, os temas que os ocuparam, e suas motivações para entrar em contato com Mário de Andrade em São Paulo.

Em outras palavras, este capítulo é a reconstrução esquemática e hipotética de um dos circuitos que o pensamento musical latino-americano teria seguido durante os anos de vida de Mário de Andrade e, em particular, é a tentativa de reconstrução dos caminhos e pontes por onde pode ter circulado o conceito de música popular na América Latina. Aqui também se dá nome próprio a um grupo de escritores que, paralelamente ao trabalho de Mário de Andrade no Brasil, se interessou pela música popular de seus países, participando da construção do conceito.

Mário de Andrade e a maioria de seus colegas latino-americanos tiveram uma formação básica como músicos, à exceção do literato mexicano Rubén Campos (1971-1945), do advogado cubano Fernando Ortíz (1881-1969), e dos brasileiros Mariza Lira (1899-1971) e Renato de Almeida (1892-1975), entre outros. Entre os músicos, alguns foram admirados em sua época por suas carreiras de compositores, como os cubanos Laureano Fuentes Matons (1825-1898), Eduardo Sánchez de Fuentes (1874-1944) e Gaspar Agüero (1873-1951), além do colombiano Emirto de Lima (1890-1972). Outros foram músicos com maior reconhecimento por seus trabalhos de pesquisa musical, como os mexicanos Gabriel Saldivar (1909) e Vicente T. Mendoza (1894-1954). Ademais, no Brasil, houve cronistas e jornalistas, como

2 O Instituto de Estudos Brasileiros (IEB) da Universidade de São Paulo (USP) guarda em seu arquivo e em sua biblioteca as coleções epistolares e bibliográficas de Mário de Andrade. A biblioteca é formada por cerca de 17 mil volumes, e o arquivo epistolar, por quase oito mil cartas. A correspondência conservada teve início em 1914, quando Mário de Andrade tinha 21 anos, e se estende até a data da sua morte. Foi objeto de inúmeros estudos desde sua organização e abertura ao público, em 1995 (Lopez, Telé Ancona. "Cartas de Mário de Andrade", O Estado de S. Paulo, Suplemento Cultura, 19 jun 1983). 
Francisco Guimarães (Vagalume) (1875-1946), Orestes Barbosa (1893-1966) e Alexandre Gonçalves Pinto (Animal), que retrataram seus ambientes mais próximos à música popular urbana e distantes do mundo acadêmico das letras e da música.

Atualmente, os escritos dos contemporâneos de Mário de Andrade lograram obter reconhecimento por parte da academia, ainda que em diferentes graus. Por exemplo, os trabalhos de alguns desses autores são considerados "pouco confiáveis" por sua formação amadora e pela distância que os separa dos paradigmas atuais da pesquisa musical, como é o caso do médico mexicano Miguel Galindo (1883-1942) e dos cronistas e jornalistas brasileiros. Outros autores caíram no esquecimento por terem obras pouco volumosas ou de escassa circulação, como o chileno Carlos Lavín (1883-1962), o colombiano Santos Cifuentes (1870-1932) ou o porto-riquenho Fernando Callejo Ferrer (1862-1926). Mas, alguns outros autores, ao contrário, foram amplamente reconhecidos por seus contemporâneos, de modo que, ainda hoje, estudam-se suas contribuições, como é o caso do argentino Carlos Vega (1898-1966) e do alemão, radicado no Uruguai, Francisco Curt Lange (1903-1997).

Em geral, considera-se que, durante as últimas décadas do século XIX e as primeiras do XX, apareceram figuras fundadoras da pesquisa musical latinoamericana. Além disso, pensa-se que todas elas estiveram muito próximas de uma visão romântica de cultura popular, a qual era ensinada pelo folclore e se harmonizava com o ambiente nacionalista da época. Mas, embora todos os autores estudados tenham respirado o mesmo "oxigênio mental”, é visível que suas leituras da realidade foram variadas e, em consequência, que cada um contribuiu com elementos interessantes para a construção do conceito de música popular, que será revisado na presente dissertação.

A maior parte da produção acadêmica desse grupo de escritores tem sido estudada criticamente em seus países de origem e de acordo com seus contextos, mas não em relação a colegas de outras áreas da América Latina. A ausência de trabalhos desse tipo é ocasionada, provavelmente, pelos poucos indícios que se tem de contatos relevantes entre eles. Com efeito, só são conhecidos poucos esforços de congregação, como aquele liderado por Francisco Curt Lange, ao criar o Instituto Interamericano de Musicologia e publicar o Boletín Latinoamericano de Música nas décadas de 
1930 e 1940. Além desse intento, existiram outras experiências, como a que se deu entre Argentina, Uruguai e Venezuela, por meio do trabalho de Carlos Vega e seus alunos e, um pouco mais tarde, pelas atividades lideradas pela Divisão de Música da União Pan-americana, sob a direção do musicólogo norte-americano Charles Seeger e, posteriormente, do músico colombiano Guillermo Espinosa, no compasso das políticas norte-americanas de boa vizinhança ${ }^{3}$.

Não obstante, nas estantes da biblioteca que pertenceu a Mário de Andrade, está reunida a maioria dos autores latino-americanos mais importantes para a pesquisa musical do momento. Sabe-se que o escritor paulistano teve contato epistolar com alguns deles. A outros, conheceu somente por meio de suas publicações e, ao que parece, não teve noticias somente de uns poucos. Antes de começar a revisar os indícios dessa rede, será feita uma breve apresentação da obra musical de Mário de Andrade em relação ao conceito de música popular. A seguir, será revisado parte dos contatos e intercâmbios que ele teve com colegas brasileiros, particularmente com Renato de Almeida, Luiz Heitor Corrêa de Azevedo e Mariza Lira. Depois, passar-se-á a seus contatos com trabalhos e colegas de países hispanoamericanos.

\section{Os escritos musicais de Mário de Andrade}

Embora os biógrafos e estudiosos de Mário de Andrade confiram-lhe o título de musicólogo, sabe-se que sua formação acadêmica foi como pianista e cantor no Conservatório Musical e Dramático de São Paulo, e que a sapiência que alcançou como escritor, literato, crítico, fotógrafo, pesquisador e musicólogo, foi autodidata.

Nos dicionários anteriores ao século XX, não existiu a palavra "musicólogo" nem "musicologia", tampouco foi incluído qualquer outro vocábulo

3 Ver: Merino, Luis. "Francisco Curt Lange (1903-1997): tributo a un americanista de excepción." Revista Musical Chilena. v. 52, no. 189 (1998); Aretz, Isabel. Síntesis de la etnomusicología en América Latina. Caracas: Monte Avila Editores, 1980; Kuss, Malena. "Leitmotive de Charles Seeger sobre Latinoamérica." Revista Musical Chilena. v. 34, no. 151 (1980). 
para denominar quem estudava música como atividade humana ou estética ${ }^{4}$ até 1927 , quando o Diccionario manual e ilustrado de la lengua española incluiu o verbete "musicógrafo: el que se dedica a escribir obras acerca de la música". Somente em 1950 foram incluídas as palavras:

Musicólogo: Persona versada en la musicología.

Musicología: Estudio científico de la teoría y de la historia de la música ${ }^{5}$.

No caso do português, o surgimento do termo "musicólogo" ocorreu mais cedo, no Dicionário Musical de Isaac Newton, publicado em 1904. Ali, definiu-se "musicólogo" como "Quem discorre sobre a arte musical"6 indicando que, no contexto brasileiro, esse tipo de estudioso já era reconhecido nos primeiros anos do século XX, talvez diferentemente da América hispanófona, onde o ofício demorou uns poucos anos mais até se popularizar?

Além disso, é importante levar em conta que o dicionário musical de 1904 não especificava que o musicólogo tinha necessariamente de se relacionar com um área institucionalizada do conhecimento. Portanto, parece coerente o fato de Mário de Andrade ter sido chamado de "musicólogo" por seus contemporâneos. Não obstante, estamos diante de um musicólogo diferente dos musicólogos atuais, que são educados segundo os princípios de uma especialidade que, no presente, conta com mecanismos institucionalizados de reprodução do saber.

Por outro lado, o instante em que as palavras musicologia e musicólogo foram incluídas nos dicionários de espanhol e português está de acordo com a

\footnotetext{
${ }^{4}$ Pelo contrário, em tais dicionários apresenta-se apenas uma entrada para "músico": "Persona que ejerce, sabe o profesa el arte de la música" (Real Academia Española. Diccionario de la lengua castellana por la Real Academia Española, Madrid: 1884) e "O que sabe e professa a música" (Moraes Silva, Antonio de. Diccionario da lingua portugueza - recopilado dos vocabularios impressos ate agora, e nesta segunda edição novamente emendado e muito acrescentado, Lisboa: 1813).

5 Real Academia Española. Diccionario manual e ilustrado de la lengua española, Madrid: 1950 Não obstante, em textos anteriores a palavra "musicólogo" foi usada, como quando o portoriquenho Fernando Callejo Ferrer, em 1915, fez a biografia do músico Carlos Casanova e lhe conferiu o título de "musicólogo", (Callejo Ferrer, Fernando. Música y músicos portorriqueños. San Juan: Tip Cantera Fernandez \& Co, 1915, p. 246) Também em Cuba, em 1923, Sanchez de Fuentes referiu-se aos "musicólogos" que desconheciam as particularidades da música cubana (Sánchez de Fuentes, Eduardo. El folk-lor en la música cubana. La Habana: Imprenta "El Siglo XX" 1923, p. 42).

${ }^{6}$ Newton, Isaac. Diccionario musical, Maceió: 1904.

7 De acordo com Joseph Kerman, o mesmo termo, "musicology", em língua inglesa, data de 1919, conforme se lê no Oxford English Dictionary. Não obstante, em 1915 o termo já tinha sido usado na revista Musical Quartely (Kerman, Joseph. Musicologia. [1985] São Paulo: Livraria Martins Fontes Editora Ltda., 1987, p. 1).
} 
história da disciplina, pois seu desenvolvimento deu-se durante o século XIX em alguns países europeus e, durante o século XX, na América Latina. Segundo os indícios nos dicionários monolíngues consultados, parece que a musicologia começou a fazer parte de nossa língua primeiro no Brasil e, depois, na América hispânica.

Considera-se que o surgimento da musicologia como disciplina na América deu-se primeiro nos Estados Unidos, principalmente no período compreendido entre as duas guerras mundiais ${ }^{8}$. Pouco depois, percebe-se no pensamento latinoamericano a ideia de que a pesquisa musical era uma área pertencente à musicologia, embora já se viesse desenvolvendo nos estudos de folclore, na historiografia e na crítica musical desde a segunda metade do século XIX. Tudo indica que foi aproximadamente nas décadas de 1930 e 1940 que a musicologia, herdeira do movimento musicológico europeu e estadunidense, começou a influenciar alguns intelectuais latino-americanos.

Por enquanto, o que interessa ressaltar é que o ofício de pensar e escrever sobre música era novo na Europa, e mais ainda na América Latina, durante a primeira metade do século XX. Isto significa que tanto Mário de Andrade quanto seus colegas latino-americanos foram um grupo de intelectuais novatos no ofício de “discorrer sobre música”, tendo sido sua formação como músicos — ou amantes da música - a base da qual partiram para se formar em pesquisa musical.

No caso de Mário de Andrade, sua formação autodidata e seu interesse pela música de seu país arrolou um grande número de escritos de diversos tipos, entre livros, artigos, ensaios, obras de caráter literário e manuscritos inacabados. Os escritos publicados saíram a público entre 1924, data em que fez 31 anos e publicou seu artigo "Marcelo Tupinambá" (1924)9, e 1945, quando morreu com 51 anos de idade e deixou publicado o prefácio ao livro Dmitri Shostakovich de Victor Seroff

8 Durante esses anos, houve uma migração de intelectuais europeus para esse país, como os musicólogos Claude V. Palisca (italiano), Paul Henry Lang (húngaro) e Alfred Einstein (alemão). Durante o mesmo período, norte-americanos como Otto Kinkeldey e Oscar Sonneck formaram-se como musicólogos na Alemanha e voltaram aos Estados Unidos para exercer a profissão.

9 Andrade, Mário de. "Marcelo Tupinambá." [1924] In: Oneyda Alvarenga (ed.), Música, doce música. Estudos da crítica e folclore, São Paulo: Livraria Martins Editora, 1976. 
$(1945)^{10}$, entre outros escritos. Com base em suas publicações musicais, e de acordo com o manejo do conceito música popular, foi esboçada uma cronologia dividida em três períodos: duas épocas principais e um período de trânsito.

Outros autores já têm feito cronologias sobre o pensamento e obra de Mário de Andrade, levando em conta outros aspectos musicais. Por exemplo, Jorge Coli apresentou uma cronologia que diferencia três períodos caracterizados pela relação que Andrade teve com o nacionalismo musical ${ }^{11}$. Por outro lado, Vivian Schelling identificou diferenças entre a obra da década de 1920 e a de 1940 em relação à cultura popular pois, para a autora, Mário de Andrade estudou o popular primeiro tendo em vista a criação de uma linguagem literária e, depois, em sua relação com a cultura intelectual ${ }^{12}$. Oneyda Alvarenga também esboçou uma diferenciação entre os trabalhos musicais de Mário de Andrade anteriores a 1940 e os seguintes, que seriam banhados por uma insatisfação em relação a sua própria obra e de sua atitude diante da vida. De acordo com Alvarenga, essa insatisfação é notada na "convicção de que o artista deve participar das lutas político-sociais de seu tempo", resumindo a oposição apresentada por meio dos libretos das óperas Malazarte e Café: a primeira seria representante da etapa nacionalizadora e a segunda, da etapa político-social ${ }^{13}$.

No presente trabalho, esboçou-se uma cronologia ligeiramente diferente, por estar apoiada em outros parâmetros. Pode-se diferenciar uma primeira época, compreendida entre 1924 e 1935, quando Mário de Andrade era professor de história da música e de estética no Conservatório Dramático e Musical de São Paulo, além de crítico de arte no Jornal Nacional e no Jornal de S. Paulo. Ao mesmo tempo, ele começou a escrever sobre cultura popular brasileira e, em 1927 e 1928, fez duas viagens de caráter pessoal ao Norte e Nordeste do país, durante as quais registrou — de forma amadora, como ele mesmo afirmou — diversos materiais para estudar os costumes musicais, coreográficos e literários dessas regiões. As experiências e o material dessas viagens alimentaram muitos de seus trabalhos de criação literária e

\footnotetext{
10 Andrade, Mário de. "Shostacovich." [1945] In: Jorge Coli (ed.), Música Final. Mário de Andrade e sua coluna jornalística Mundo musical, São Paulo: Editora da Unicamp, 1998.

${ }^{11}$ Coli, Jorge. "Mário de Andrade - Introdução ao pensamento musical." Revista do Instituto de Estudos Brasileiros. no. 12 (1972).

12 Schelling, Vivian. A presença do povo na cultura brasileira: ensaio sobre o pensamento de Mário de Andrade e Paulo Freire. Campinas: Universidade Estadual de Campinas, 1991, p. 124.

13 Alvarenga, Oneyda. "Mário de Andrade e a música." In: Oneyda Alvarenga (ed.), Mário de Andrade, um pouco, Rio de Janeiro / São Paulo: SCET Livraria José Olympio Editora, 1974, p. 56.
} 
de pesquisa musical, ressaltando-se a série de artigos "O turista aprendiz"14. Desse período, são também alguns de seus textos mais importantes e lidos sobre música: Ensaio sobre a música brasileira $(1928)^{15}$, Compêndio de história da música (1929) 16, Modinhas imperiais (1930) ${ }^{17}$ e vários de seus artigos publicados em Música, doce música $(1933)^{18}$.

O segundo período poderia ser considerado como uma época de trânsito em que começaram a aparecer transformações em suas concepções musicais, particularmente sobre música popular. Esse período teve início em 1935, quando Mário de Andrade foi nomeado chefe do Departamento de Cultura da cidade de São Paulo, extendendo-se a sua renúncia, em 1938, e à temporada seguinte, em que viveu no Rio de Janeiro, até voltar para São Paulo, em 1941. Durante esses quase seis anos de convivência direta com as políticas brasileiras, e de contato com a vida musical e intelectual da capital do país, Andrade publicou textos que mostram os gérmens de mudanças importantes, os quais caracterizarão sua perspectiva sobre o vocábulo música popular do período seguinte. Entre outros artigos, destacam-se "A música e a canção populares no Brasil. Ensaio crítico-biográfico" (1936) ${ }^{19}$, “O samba rural paulista" (1937) 20 e "Música popular" (1939)²1.

O terceiro e último período teve início, mais ou menos, durante seu "exílio" no Rio de Janeiro, terminando em 1945, ano de sua morte. Entre os aspectos mais importantes, já assinalados por outros autores, está sua preocupação manifesta com o papel do artista e da arte na sociedade, provavelmente como resultado das reflexões

${ }^{14}$ Publicado como uma série de artigos no Diário Nacional e, depois, como livro em: Andrade, Mário de. O turista aprendiz. [1928-9] São Paulo: Duas Cidades / SCCT, 1983.

15 Andrade, Mário de. Ensaio sobre a música brasileira. [1928] São Paulo: Livraria Martins Editora, 1972.

${ }^{16}$ Andrade, Mário de. Compêndio de história da música. São Paulo: I Chiarato \& Cia, 1929.

${ }^{17}$ Andrade, Mário de. Modinhas Imperiais. [1930] Sao Paulo: Livraria Martins Editora, 1964.

18 A primeira versão, de 1933, não inclui 25 artigos, adicionados na edição de 1976 por Oneyda Alvarenga, segundo indicação de Mário de Andrade. Para este trabalho foi consultada a terceira edição: Andrade, Mário de. Música, doce música. Estudos da crítica e folclore. [1933] São Paulo: Livraria Martins Editora, 1976.

19 Andrade, Mário de. "A música e a canção populares no Brasil. Ensaio críticobibliográfico." [1936] In: Oneyda Alvarenga (ed.), Ensaio sobre a música brasileira, São Paulo: Livraria Martins Editora, 1972.

20 Andrade, Mário de. "O samba rural paulista." [1937] In: Oneyda Alvarenga (ed.), Aspectos da música brasileira, Belo Horizonte, Rio de Janeiro: Vila Rica Editoras Reunidas Ltda, 1991.

21 A essa época pertence o famoso artigo "O artista e o artesão", publicado originalmente em 1938 (Andrade, Mário de. "O artista e o artesão." [1938] O baile das quatro artes, São Paulo: Livraria Martins Editora, 1963). 
despertadas por sua passagem, anos antes, pelo Departamento de Cultura, e da comoção causada pelo início da Segunda Guerra Mundial. Mário de Andrade fez um chamado constante ao artista para que se envolvesse profundamente com os problemas de seu tempo, pois, “entre 1940 e 45, para o Mário, a arte adquirirá, mais do que nunca, uma função de arma, de luta ${ }^{22}$. Durante os últimos cinco anos de sua vida, e enquanto trabalhava novamente como professor do Conservatório Dramático Musical de São Paulo e como crítico musical na Folha da Manhã, publicou textos representativos de suas últimas preocupações, tais como "Romantismo musical” (1941) 23 , "Evolução social da música no Brasil” (1941)²4, "Atualidade de Chopin" (1942)25, “O banquete" $(1943)^{26}$ e "Cândido Inácio da Silva e o lundu" $(1945)^{27}$. Ainda que, nesse último período, tenha havido uma radicalização e revisão de ideias anteriores, Mário de Andrade morreu sem fazer uma reflexão amadurecida sobre sua produção como um todo, ou sem apresentar uma síntese do seu pensamento. Portanto, esses escritos não podem ser considerados como seu pensamento conclusivo.

A partir desses recortes temporais, foram identificados alguns temas que Mário de Andrade privilegiou em diferentes momentos de sua vida, e que envolveram suas ideias em torno do popular, folclórico e popularesco. Na realidade, essas preocupações atravessaram toda sua obra, mas os destaques dados a cada uma foram mudando com o correr do tempo. Por exemplo, a relação entre folclore e música popular apareceu com maior notoriedade na primeira época. Depois, pouco a pouco, delineou-se melhor sua distância da concepção clássica do folclore e, em sua época de trânsito, percebem-se reflexões sobre a necessária inclusão de fenômenos musicais urbanos no estudo do folclore brasileiro. Já na terceira época, além de ser evidente seu interesse por alguns fenômenos urbanos, o termo popularesco destacase como uma palavra usada com maior frequência para denominar uma porção do

${ }^{22}$ Coli. "Mário de Andrade - Introdução ao pensamento musical." p. 124.

${ }^{23}$ Andrade. "Romantismo musical." [1941] O baile das quatro artes.

24 Andrade, Mário de. "Evolução social da música no Brasil." [1941] In: Oneyda Alvarenga (ed.), Aspectos da música brasileira, Belo Horizonte - Rio de Janeiro: Villa Rica Editoras reunidas limitada, 1991.

25 Andrade. "Atualidade do Chopin." [1942] O baile das quatro artes.

${ }^{26}$ Andrade, Mário de. O banquete. [1943] São Paulo: Livraria Duas Cidades, 1977.

27 Andrade, Mário de. "Cândido Inácio da Silva e o lundu." [1945] Latin American Music Review. v. 20, no. 2 (1999). 
repertório que estudava. Além disso, surgiram discussões mais amadurecidas sobre os processos de popularização e folclorização, junto a críticas severas ao meio musical que o rodeava.

Uma pista que serve para compreender o popular na obra de Mário de Andrade foi ter levado em conta que sua própria história familiar e pessoal faz dele "um singularíssimo caso de interiorização cabal das ambivalências brasileiras, em planos sociológicos, antropológicos e psicanalíticos"28. José Miguel Wisnik recorda que Mário de Andrade era neto de Joaquim do Almeida Leites Moraes, presidente da província do Goiás em 1881, jornalista, professor de direito, liberal e autor de Apontamentos de viagem. Esse avô, que pertencia a uma família tradicional abastada, com certa envergadura política e intelectual, e que tinha acesso a círculos do poder monárquico do Segundo Império, casou-se com Ana Francisca, filha de uma lavadeira. Esse "avô presidente", depois, casou sua filha Maria Luísa com seu secretário pessoal e bibliotecário, Carlos Augusto do Andrade, reconhecido por ele como uma espécie de filho, pois vinha de origem humilde e não tinha pai. Para complicar um pouco mais as coisas - usando as palavras de Wisnik -, a mamãe de Carlos Augusto de Andrade era prima de Ana Francisca, esposa do "avô presidente", e essa relação entre mãe e sogra envolvia Carlos Augusto em um laço de consanguinidade com sua esposa, convertendo o "avô presidente" em pai da família paterna e materna ao mesmo tempo ${ }^{29}$. De acordo com Wisnik, na vida de Mário de Andrade confundem-se o paradigma aristocrático e o substrato popular anônimo, o qual poderia chegar a ser considerado como um dos motores inconscientes que impulsionaram seus interesses acadêmicos. Florestan Fernandes, em 1946, também notou a busca em relacionar o folclórico com o erudito na obra de nosso autor, além de notar que esse interesse era "como um problema psicológico pessoal que Mário de Andrade enfrenta e resolve questão" 30 .

Justamente nessa vida familiar, em sua relação com amigos, colegas, livros, cartas, partituras e discos, vale a pena estudar a construção do conceito de música

\footnotetext{
${ }^{28}$ Wisnik, José Miguel. "O ensaio impossível." In: Sergio Miceli, et al. (ed.), Gilda, a paixão pela forma, Rio de Janeiro: Ouro sobre azul, 2007, p. 219.

29 Ibid.

${ }^{30}$ Fernandes, Florestan. "Mário de Andrade e o folclore brasileiro." [1946] Revista do Instituto de Estudos Brasileiros. v. 36, (1994).
} 
popular, pois se considera que as categorias mentais, tanto de Mário de Andrade quanto de qualquer outro intelectual, não crescem em seus cérebros de maneira espontânea, mas sim são geradas por referentes externos. Na medida em que possam ser reconstruídas essa relações, será mais fácil a compreensão do processo de construção de seu conhecimento.

\section{Conversando com colegas brasileiros}

Mário de Andrade não foi a única pessoa que se interessou em escrever sobre a música popular de seu país. Ao contrário, e em concordância com a importância dada ao popular pelo romantismo e pelo influxo nacionalista, houve outros intelectuais que, no século XIX, já se aproximavam do mundo da arte popular, e que tinham criado a necessidade de fazer dela um objeto de estudo. Da perspectiva do folclore, outros autores, como Alexandre José Mello Morais (1844-1919), Sílvio Romero (1851-1914), Alexina Magalhães Pinto (1870-1921) e Amadeu Amaral (1875-1929), iniciaram estudos que serão continuados por Mário de Andrade de forma mais sistemática e inovadora, além de alguns outros de sua geração ${ }^{31}$.

Embora, a obra de Mário de Andrade tenha sido a que gozou de maior reconhecimento entre seus contemporâneos - e até hoje seja paradigmática —, são importantes os diálogos que ele entabulou com outros estudiosos da música popular, particularmente com Renato de Almeida, Luiz Heitor Corrêa do Azevedo e Mariza Lira. Todos eles radicados no Rio de Janeiro, e sendo aqueles que depois da sua morte passaram a ocupar, de uma forma ou de outra, o espaço deixado por seu colega na pesquisa musical brasileira. Foi deixada de fora deste capítulo a relação que Mário de Andrade manteve com Luiz da Câmara Cascudo porque, ainda que este tenha sido um dos principais estudiosos da cultura popular brasileira naquele momento, seus trabalhos não se concentraram na área musical ${ }^{32}$. Tampouco foi aprofundada a

31 Ver: Moraes, José Geraldo Vinci de e Machado, Cacá. "«Música em conserva»: memória e história da música no Brasil." La memoria histórica y sus configuraciones temáticas. Una aproximación interdisciplinaria, Montevideo: Ediciones Cruz del Sur, 2011.

32 De acordo com Cláudio Augusto Pinto Galvão, o material musical não foi central na obra de Câmara Cascudo (Galvão, Claudio Augusto Pinto. Alguns compassos. Câmara Cascudo e a música (1920/1960). (Teses) Universidade de São Paulo, 2011), mas ele desempenhou um papel importante dentro de sua visão da cultura popular. Para um melhor conhecimento da amizade entre Mário de Andrade e Luiz da Câmara Cascudo, ver sua correspondência em: Cascudo, Luís da Câmara, Andrade, Mário de et al. Câmara Cascudo e Mário de Andrade: cartas 1924-1944. São Paulo: Global Editora, 2010 . 
relação intelectual que Andrade manteve com sua aluna e amiga Oneyda Alvarenga, porque seria preciso uma pesquisa concentrada para cobrir o rico intercâmbio que houve entre eles. Uma mostra da profunda confiança que teve o professor em sua aluna foi o fato de Oneyda Alvarenga ter herdado a tarefa de publicar os trabalhos inéditos sobre música de seu professor ${ }^{33}$. Tampouco será aprofundada a relação que houve entre Mário de Andrade e os chamados memorialistas da música popular urbana, Francisco Guimarães (Vagalume), Alexandre Gonçalves Pinto (Animal) e Orestes Barbosa, por não terem sido encontrados indícios de proximidade entre eles.

\subsection{Dois velhos amigos}

A primeira carta entre Renato de Almeida e Mário de Andrade data de 10 de maio de 1922. Segundo a correspondência, parece que eles tiveram seus primeiros intercâmbios intelectuais quando tinham 30 e 29 anos, respectivamente, e que seu primeiro contato deveu-se a publicação do livro Fausto: ensaio sobre o ser (1922), de Almeida. Naquela época, fazia cinco anos que Renato de Almeida graduara-se pela Faculdade de Ciências Jurídicas e Sociais e dedicava-se à advocacia, enquanto trabalhava como jornalista no Monitor Mercantil e em América Brasileira. Almeida era discípulo de Graça Aranha e, possivelmente, por meio dele e de Ronald de Carvalho - editor de seu livro Fausto e amigo de Mário de Andrade -, relacionou-se com diferentes artistas do movimento modernista brasileiro. Hoje em dia, Renato de Almeida é reconhecido como um importante folclorista graças a seu trabalho na Comissão Nacional de Folclore e ao fato da maioria de seus escritos versarem sobre esse tema ${ }^{34}$. Entretanto, durante as décadas de 1920, 1930 e 1940, seus interesses foram ecléticos, e ele descreve-se-ia, simplesmente, como um pensador ${ }^{35}$.

Renato de Almeida foi autor de uma das mais importantes histórias da música brasileira do período em que Mário de Andrade viveu. Seu livro teve duas

\footnotetext{
33 A Respeito da obra musicológica de Oneyda Alvarenga, a musicóloga Luciana Barongeno está trabalhando no manuscrito de sua autoria, "A linguagem musical", escrito sob a orientação de Mário de Andrade. Esta pesquisa será sua tese de doutorado junto ao programa de Música da Universidade de São Paulo, sob a orientação da professora doutora Flávia Camargo Toni.

34 Acerca da importância de Renato de Almeida no movimento folclorista brasileiro, ver: Vilhena, Luis Rodolfo. Projeto e Missão. O movimento folclórico brasileiro 1947-1964. Rio de Janeiro: Funarte e Fundação Getulio Vargas Editora, 1997.

35 Carta de Renato de Almeida, RJ, nov. 1926. In: Nogueira, Maria Guadalupe Pessoa. Edição anotada da correspondência Mário de Andrade e Renato de Almeida. (Dissertação) Universidade de São Paulo, 2003, p. 117.
} 
edições, uma em 1926 e outra em 1942. Embora em ambas edições a música popular tenha gozado do protagonismo, o conceito manejado pelo autor é difuso e suas contribuições mais claras foram posteriores, mediadas pela força que o movimento folclórico teve no Brasil entre as décadas de 1940 e 1960.

Não obstante, são comparadas as duas edições de sua História da música brasileira e sua relação com Mário de Andrade porque, por meio delas, pode-se ver parte do processo de consolidação da formação acadêmica de Renato de Almeida e o início de sua posterior ligação com o folclore.

Embora a primeira edição da História da música brasileira (1926) não seja fundadora da historiografia musical brasileira, posto que já se contava com o livro de Guilherme Theodoro Pereira de Mello, publicado em 1908, sua importância esteve ligada ao momento intelectual que o Brasil então vivia.

De acordo com Eduardo Jardim Morais, o movimento modernista brasileiro pode ser dividido em duas etapas. Entre 1917 e 1924, o modernismo absorveu os resultados das vanguardas europeias, brigando radicalmente contra o passadismo e o romantismo. Em contrapartida, na etapa seguinte, esse movimento passou a se preocupar com a construção de uma identidade nacional brasileira ${ }^{36}$. Renato de Almeida começou a escrever seu livro em $1923^{37}$, quando o modernismo era uma corrente de tinturas revolucionárias, mas parece que sua publicação, três anos depois, foi tardia em relação às expectativas de seus colegas modernistas, posto que o livro recebeu algumas críticas e o autor decidiu escrever uma segunda edição ${ }^{38}$.

O principal defeito que seus contemporâneos encontraram na obra de Renato de Almeida foi a falta de utilidade prática, ou seja, de elementos concretos que permitissem reconhecer a essência da música brasileira ${ }^{39}$. Essa foi a principal

\footnotetext{
${ }^{36}$ Morais, Eduardo Jardim. A brasilidade modernista: sua dimensão filosófica. Rio de Janeiro: Edições Graal, 1978.

${ }^{37}$ Carta de Renato de Almeida, RJ, oct. 1923, e Carta de Mário de Andrade, SP, 8 nov. 1926 In: Nogueira. Edição anotada da correspondência Mário de Andrade e Renato de Almeida. p. 45 y 163.

${ }^{38}$ Em carta de 8 nov. 1926, Mário de Andrade lembrou a Renato de Almeida que quando este leu, em São Paulo, as observações de Mário de Andrade nas margens de seu livro, "ficamos combinados de você fazendo edição nova do livro eu mandar elas pra você ver o que poderia concordar e aceitar", ao que Renato de Almeida respondeu: "E tanto, é assim que lhe pedi me enviasse, para a $2^{\mathrm{a}}$ edição da História, as suas objeções, porque aceitarei quantas me convencerem e poderei até contestar aquelas que me pareçam erradas” In: Ibid., pp. 163-164 y 179.

39 Andrade. "Ernesto Nazaré." [1926] Música, doce música. Estudos da crítica e folclore, p.
} 
observação feita tanto por Mário de Andrade, em suas cartas, quanto por Prudente do Moraes Neto, em uma resenha publicada na Revista do Brasil, na qual lamentou o caráter pouco analítico do autor e a falta de pesquisa, já que "tudo é dito com a segurança das coisas conhecidas e fora de discussão" 40 .

De sua parte, Mário de Andrade explicou ao amigo Renato de Almeida que essa utilidade prática que se reclamava de seu texto relacionava-se com a seguinte lógica:

você não acha por exemplo que sob qualquer ponto de vista nos será muito mais útil e de validade mais geral (pois que isso de opinião estética sobre um músico e quase ou só pessoal e mesmo transitório dentro duma pessoa) se saber afinal, quando apareceu o maxixe, donde o nome dele etc.? sem dúvida que é. Você elogia Velásquez, um indivíduo escuta Velásquez por causa do elogio e conclui gosto ou não gosto. E pronto. Ou não comprará Velasquez que é o que se dará na imensa maioria. Agora, se você que está ai no Rio depois de pesquisas penosas e paciente me dava no seu livro: a origem histórica do maxixe é esta, se nome veio disto, etc. Todo o mundo ficava sabendo coisas novas, coisas cujo mérito de saber (e eu estou inteiramente com você a respeito de saber, você sabe disso) só dependeu de você. Era você o homem que fez alguma coisa pra nossa musicologia normativa histórica. É ou não é! O nome de você se ligaria a uma das fontes e um dos pontos mais importantes da musicologia nacional. E tudo isso que aponto não carece de saber música pra fazer. E você podia ter feito. E não fez ${ }^{41}$.

As duas edições da História da música brasileira de Renato de Almeida, publicadas com 16 anos de diferença, poderiam ser consideradas dois livros diferentes. A edição de 1926 assemelha-se a um ensaio literário acerca de música, ao passo que a segunda se parece mais com um trabalho próximo à pesquisa histórica. $\mathrm{O}$ mesmo Renato de Almeida mencionou que a primeira edição merecia mais o título de "ensaio", e que não era um trabalho de pesquisa porque,

...eu não sou dado a esses labores que exigem paciência, em mim minguada, e um espiritu de metodização, que não possuo. Sabe você que todo o meu trabalho é, sobretudo, de pensamento e aquela a sedução da idéia me fascina imediatamente. Onde não a encontro, o esforço enerva-me e retrocedo ${ }^{42}$.

Contrária à sua própria opinião, a edição de 1942 esteve baseada em um longo trabalho de pesquisa sob a orientação de Mário de Andrade. A maioria dos dados fornecidos por Renato de Almeida em seu novo livro, em geral, esteve apoiada

\footnotetext{
${ }^{40}$ A resenha começa dizendo: "O que a música brasileira sugeriu ao sr. Renato de Almeida foi um livro de literatura". E termina com a frase "História da música brasileira? História dos músicos brasileiros, precedida e acompanhada de comentários" Moraes Neto, Prudente de. "História da Música Brasileira, Renato de Almeida, Livraria Briguiet, Rio, 1926." Revista do Brasil. v. 1, no. 1 (1926).

41 Carta de Mário de Andrade, SP, 8 nov. 1926 In: Nogueira. Edição anotada da correspondência Mário de Andrade e Renato de Almeida. p. 167.

${ }^{42}$ Carta de Renato de Almeida, RJ, nov. 1926. In: Ibid., p. 177.
} 
em algum tipo de documentação, citada com algum rigor. A inclusão, organização e estudo do material musical foram cuidadosos, e suas opiniões estiveram bem diferenciadas das de outros autores.

Renato de Almeida iniciou o prefácio de sua segunda edição dizendo que esse era um livro novo e que algumas conclusões e ideias gerais tinham sido mantidas, mas que havia mudado a construção, as dimensões, a matéria, a investigação e o material recolhido. Ele relacionou suas duas edições assim:

Em 1926, resumi as impressões e os dados históricos que me permitiam concluir pela afirmação da existência de uma música brasileira, haurida nas fontes populares e que se tinha formando lentamente através do tempo. Hoje apresento o processo que comprova aquelas conclusões ${ }^{43}$.

Os índices temáticos das duas edições mudaram visivelmente. A edição de 1926 iniciava com uma introdução chamada "A sinfonia da terra", na qual foi notória a influência que o naturalismo teve no papel atribuído à paisagem e à raça na configuração das $\operatorname{artes}^{44}$. Depois segue uma narração, em ordem cronológica, que inicia no século XIX, e se destacam os capítulos dedicados ao romantismo e ao espírito moderno na música. A estrutura dessa primeira edição parece ter a intenção de ressaltar os movimentos romântico e modernista, talvez, com o ímpeto de reivindicar as posturas deste último, do qual Renato de Almeida sentia-se parte.

A mudança mais notória que o índice da segunda edição sofreu está na divisão temática em duas grandes partes: a primeira dedicada exclusivamente à música popular e a segunda, ao relato histórico-musical acerca da música erudita. A parte sobre música popular é mais próxima dos trabalhos etnográficos de sua época, enquanto que a segunda tem como eixo uma organização cronológica.

Sobre a primeira parte do livro, Renato de Almeida disse:

\footnotetext{
${ }^{43}$ Almeida, Renato. História da música brasileira. [1926] Rio de Janeiro: F. Briguiet, 1942, p. XI.

${ }^{44}$ A influência do naturalismo nos discursos musicais foi frequente desde as últimas décadas do século XIX. Assumiu-se que a natureza, o clima e a paisagem determinavam a caracterização da música de cada país. O músico argentino Arturo Schianca, por exemplo, também iniciou sua Historia de la música argentina com um capítulo intitulado "Influencia del medio ambiente geográfico en nuestra música" (Schianca, Arturo. Historia de la música argentina. Orígen y características. Buenos Aires: Establecimiento gráfico argentino, 1933). Não obstante, existiram algumas críticas a esse determinismo geográfico, como a expressa por Carlos Vega ao afirmar: "La naturaleza circundanteríos, pampas, selvas, montañas — no tiene influencia alguna sobre las formas coreográficas y musicales, ni sobre su realización". (Vega, Carlos. Danzas y canciones argentinas. Teorías e investigaciones, un ensayo sobre el tango. Buenos Aires: Establecimiento Gráfico de Eugenio Ferrero, 1936, p. 37).
} 
O estudo da música popular me pareceu fundamental e procurei abrangê-lo com o maior alcance possível, dentro das diretivas dêste livro, que não é contudo de pesquisa folclórica, sinão de história ${ }^{45}$.

O novo índice temático foi discutido com Mário de Andrade pois, em 1939, Renato de Almeida perguntava-lhe se a palavra "universalitas" estava bem usada para denominar uma das tendências da música brasileira. Almeida tentou recordar ao escritor paulistano a última vez que estivera em sua casa e discutiram o plano do livro, para que pudesse ajudá-lo a escolher ${ }^{46}$.

Em relação às fontes bibliográficas da segunda edição, é evidente um aumento em número e diversidade, em comparação com as usadas na primeira. A intenção de apoiar seus argumentos em métodos de pesquisa, levou Renato de Almeida a enumerar com maior disciplina suas fontes documentais, e é notória a leitura de autores contemporâneos interessados na nova música popular urbana, como Francisco Guimarães (Vagalume), Orestes Barbosa e Alexandre Gonçalves Pinto (Animal). Ao que parece, Renato de Almeida também usou informação fornecida por Almirante, com quem manteve alguma amizade ${ }^{47}$.

Ademais, Renato de Almeida teve acesso a alguma bibliografia latinoamericana sobre história musical e folclore, como textos dos mexicanos Rubén Campos e Vicente T. Mendoza, do cubano Eduardo Sánchez de Fuentes, dos argentinos Carlos Vega e Samuel Salga e do espanhol, radicado no México, Adolfo Salazar ${ }^{48}$. Além disso, foi leitor assíduo de seus contemporâneos Mário de Andrade, Gastão do Bethencourt, Luiz da Câmara Cascudo, Heitor Correia de Azevedo, Mariza Lira e Alexina Magalhães, entre outros.

Em inícios de 1938, as consultas de Renato de Almeida a seu amigo fizeram-se mais frequentes por causa de seu trabalho na segunda edição de sua História da música brasileira. A influência que Mário de Andrade teve sobre a nova edição é visível ao comparar o livro publicado com a correspondência entre eles e

${ }^{45}$ Almeida. História da música brasileira. [1926] p. XI.

46 Carta de Renato de Almeida, RJ, 2 fev. 1939. In: Nogueira. Edição anotada da correspondência Mário de Andrade e Renato de Almeida. p. 310.

47 Graças ao relato de Mariza Lira a respeito de uma exposição sobre samba que Renato de Almeida apresentou no Rio de Janeiro em 1941, sabe-se que alguns dos exemplos musicais que ele usou foram cantados por Almirante (Carta de Mariza Lira, RJ, 15 set. 1941. IEB-USP: 4235).

48 Todos esses livros encontram-se na biblioteca de Mário de Andrade, e se pode inferir seu eventual empréstimo a Renato de Almeida. 
com as numerosas citações que Renato de Almeida fez das publicações de Mário de Andrade.

Por exemplo, Mário de Andrade aconselhou incluir os compositores vivos em termos estéticos depois de Almeida perguntar-lhe que critério usar para manter a objetividade. Mário de Andrade opinou que o melhor era escolher uma data para falar de compositores anteriores e posteriores, e não ter medo de usar adjetivos críticos de forma pragmática, pois,

...se você falar dos "vivos" sem adjetivos, é não tomar posição, é fugir da crítica histórica, é ter medo de errar. E é não orientar, não dar sua opinião. Fugir do papel de orientador, de professor que todo historiador, mesmo do presente, deve ter ${ }^{49}$.

Mário de Andrade também ofereceu a Renato de Almeida inúmeras referências bibliográficas para complementar seu trabalho, como exemplificam suas sugestões sobre a tirana ${ }^{50}$. $\mathrm{O}$ autor paulistano tampouco hesitou em chamar a atenção sobre a escritura de Renato de Almeida, corrigindo o uso da palavra "forma" 51 no contexto musical, assim como a maneira em que Almeida estava entendendo os gêneros musicais populares:

Antes de mais nada, não diga, como na sua última carta «quanto à chimarrita e à tirana consegui a música e os versos etc.». Você não conseguiu a música e os versos, mas apenas uma das músicas e alguns dos versos. Principalmente tirana é nome genérico, como «valsa» ou «coco», ou melhor, «canção» ${ }^{52}$.

Ao que Renato de Almeida respondeu: "A sua carta me tirou uma dúvida. Pelas indicações que tinha, julguei que houvesse uma música de «chimarrita», uma de «tirana» etc. $" 53$.

Por outro lado, as mudanças que o movimento modernista teve por volta de 1924 — segundo estudo de Eduardo Jardim Morais — provavelmente influenciou a segunda edição do livro de Renato de Almeida. A revisão do escrito esteve baseada em trabalho de pesquisa e preocupada com o auto-conhecimento da cultura musical brasileira, em conformidade com outros trabalhos da literatura modernista. Nesse

49 Carta de Mário de Andrade, SP, 18 mai. 1938. In: Ibid., p. 294.

${ }^{50}$ Ibid., p. 300.

51 "Embora também já tenha empregado, confesso embirrar tecnicamente com a palavra «formas». Não se trata propriamente de formas, antes de «modalidades», «manifestações» da música popular brasileira. Não havendo diferenciação de compasso, nem de ritmo, nem de movimento, nem estrófica, não se pode falar de «formas»." Carta de Mário de Andrade, SP, 7 mai. 1938. In: Ibid., p. 286.

${ }^{52}$ Carta de Mário de Andrade, SP, jun. 1938. In: Ibid., p. 303.

${ }^{53}$ Carta de Renato de Almeida. RJ, 24 jun.1938. In: Ibid., p. 306. 
momento, autores como Mário de Andrade e Oswald de Andrade advogavam pela construção do conhecimento sobre o Brasil e valorizavam tanto a forma intuitiva quanto a pesquisa que era feita. Esse equilíbrio entre a base investigativa do trabalho do Almeida e as expectativas de seu meio fez com que, dessa vez, seu livro tivesse melhor acolhida.

Por parte de Mário de Andrade, a segunda edição da História da música brasileira (1942) recebeu melhores comentários:

...venho lhe dar o meu maior abraço de aplauso. Realmente, sem a menor condescendência de amigo urso, você fez uma obra admirável. Se sob apenas o ponto de vista da música histórica ele não é "técnico" minha convicção é que ele não tinha que ser técnico. Se o fosse você se dispersaria numa ladeira de observações de caráter monográfico e seu livro perderia a unidade esplêndida que tem. Agora sim: seu livro ficou sendo um ponto de partida pra monografias, uma obra de consulta imprescindível ${ }^{54}$.

Além disso, nessa mesma carta, Mário de Andrade aplaudiu o autor por não ter usado a terminologia da teoria musical europeia para descrever a música indígena. Também fez outros comentários laudatórios no artigo "Música brasileira", do mesmo ano, no qual resenhou a nova edição do livro ${ }^{55}$.

Por sua vez, Renato de Almeida respondeu efusivamente, recordando-lhe a carta que lhe escrevera por ocasião da primeira edição e reconhecendo que, graças às suas observações e indicações, Mário de Andrade teve um papel predominante na segunda edição:

Está claro que me inclinei pelo seu modo de ver, pois do contrário nada teria feito. Chegamos a falar nisso, mas era preciso você ver a coisa em função, de sorte que temia estar em erro. Sua carta desfez o temor. [...], mas estou aqui a lhe fazer uma confidência, numa hora em que você me dá uma das grandes alegrias da minha vida. Eu fiz o que eu quis - um livro que merecesse o seu aplauso ${ }^{56}$.

Por outra lado, uma das principais desvantagens que Renato de Almeida teve na pesquisa musical foi sua escassa formação em música. Ele mesmo reconheceu, em uma carta na qual se defendia dos comentários à primeira edição de sua História da música brasileira, que não era musicólogo nem músico e que, portanto, não podia ser aquele um trabalho musical, mas apenas um grito, que dizia:

${ }^{54}$ Carta de Mário de Andrade, SP, 2 mar. 1942. In: Ibid., p. 346.

${ }^{55}$ Andrade. "Música brasileira." [1942] Música, doce música. Estudos da crítica e folclore.

56 Carta de Renato de Almeida, RJ, 4 mar. 1942. In: Nogueira. Edição anotada da correspondência Mário de Andrade e Renato de Almeida. p. 349. 
vejam que enorme riqueza tem nossa música, que tem sido desprezada e lembremse que sem ela, não só não criarão uma verdadeira arte musical, como não descobrirão nunca o verdadeiro espirito brasileiro ${ }^{57}$.

Não obstante, um pouco mais tarde, Renato de Almeida admitiu que era necessário um melhor conhecimento do material musical que estudava, contando a Mário de Andrade que as partituras que chegavam às suas mãos eram tocadas por sua mãe e ele, assim, ouvia a música que continham ${ }^{58}$.

Parece que o pouco conhecimento musical de Almeida não passou desapercebido entre seus colegas, subtraindo credibilidade de seus trabalhos pois, em carta de 1941, Mariza Lira contou a Mário de Andrade que Renato de Almeida não causara uma boa impressão na conferência que deu no Rio de Janeiro por ocasião da abertura da exposição de material folclórico:

Achei fraca a conferencia do Renato. Quis fugir a vulgaridade da "Historia do samba com seus personagens e lendas" e não foi feliz. Falou em origem do samba misturando com cordão carnavalesco, disse que o samba era carioca que o samba subiu ao morro, deu uma definição complicada do samba, tendo antes afirmado ser professor de lógica, em fim, não foi feliz. Musicalmente ele é como eu, não tem competência para analisar nada e a impressão que tive foi de um palhaço em trapeiro. Aliás o reparo não foi só meu, o professor Ribas Carneiro comentou contrariamente. Não escreveu a conferencia e foi melhor ou pior. Usou dos advérbios de modo, das conjunções prolongadas e mais que tudo da afirmatura muito interessante interessantíssimo. A vitrola falhou, para exemplificar, mas assim mesmo ronquenha e desafinada insistia-se na exemplificação. Mesmo que estivesse boa mal escolhida. Foi o Almirante o interprete, sem voz sem graça e de pronuncia nortexda ( $\mathrm{sic}$ ). Não gostei da conferencia do Renato, embora tivesse tido grande boa vontade e trabalho ${ }^{59}$.

É provável que o escasso conhecimento da teoria musical de Renato de Almeida terminasse influenciando em seu conceito de música popular, já que suas definições parecem apagar as características nitidamente musicais e centrar sua atenção em parâmetros extra-musicais, como se verá no seguinte capítulos. É importante sublinhar que, em geral, na época foi escassa a atenção dada ao material musical para definir o que era música popular.

${ }^{57}$ Carta de Renato de Almeida, RJ, 2 dez. 1926. In: Ibid., pp. 160-162.

58 “...por mais que a leitura da partitura seja difícil para juízo seguro, ainda para os que como eu, as fazem tocar, trabalho de que se incumbe minha mãe." (Carta de Renato de Almeida, Rio de Janeiro, após 18 mai. 1938. In: Ibid., p. 297).

${ }^{59}$ Carta de Mariza Lira, RJ, 15 set. 1941. IEB-USP: 4235. 


\subsection{Um jovem músico pesquisador}

O mais jovem dos autores que mantiveram correspondência com Mário de Andrade, e que também se interessou pela pesquisa musical, foi Luiz Heitor Corrêa de Azevedo. Embora nas cartas consultadas os dois pesquisadores não discutissem temas musicais em profundidade - como aconteceu com Renato de Almeida sendo seus assuntos mais logísticos, será dada uma folheada rápida em seus intercâmbios, dada a importância que Corrêa de Azevedo teve após a morte de Mário de Andrade, como um dos mais destacados estudiosos e gestores da música brasileira a nível nacional e internacional, e como um dos intelectuais preocupados com o estudo da música popular, entendida como fenômeno folclórico.

Luiz Heitor Corrêa de Azevedo formou-se músico no Instituto Nacional de Música entre os 19 e 23 anos de idade e, imediatamente depois, começou a escrever nos periódicos $O$ imparcial e $A$ ordem. Em 1930, com apenas 25 anos, fez parte do grupo que fundou a Associação Brasileira de Música, junto com músicos reconhecidos como Luciano Gallet e Lorenzo Fernandez, e exerceu a função de secretário dessa Associação até 1933. Nesse emprego, o jovem músico iniciou sua correspondência com Mário de Andrade, no cumprimento de suas funções de secretário $^{60}$, e a partir de 1933 continuou, com um trato mais pessoal, depois de se conhecerem no hotel Itajubâ, no Rio de Janeiro, em uma das visitas de Mário a essa cidade $^{61}$.

Em 1932, enquanto trabalhava na Associação Brasileira de Música, Corrêa de Azevedo sucedeu Guilherme de Mello - autor da primeira história da música no Brasil - no cargo de bibliotecário do Instituto Nacional de Música. Nesse novo trabalho, continuou mantendo correspondência com Mário de Andrade, dessa vez respondendo a suas consultas bibliográficas e ajudando-o na busca de material musical na biblioteca ${ }^{62}$. Como bibliotecário, Corrêa de Azevedo organizou o Arquivo

\footnotetext{
60 Por exemplo, a carta em que comunica a Mário de Andrade que este foi aceito como sócio correspondente da Associação Brasileira de Música. (Carta de Luiz Heitor Corrêa de Azevedo, RJ, 19 ago. 1930. IEB-USP: MA-C-CP862).

${ }^{61}$ Azevedo, Luiz Heitor Corrêa de. "As minhas cartas de Mário de Andrade." Latin American Music Review. v. 1, no. 1 (1980).

62 Ver, por exemplo, carta de Luiz Heitor Corrêa de Azevedo acerca da tese de João Nunes, “Intelligencia musical" (RJ, 1 set. 1933. IEB-USP: 876), e carta a respeito da existência de registros de música popular na Biblioteca (Carta de Luiz Heitor Corrêa de Azevedo, RJ, 23 dez. 1935. IEBUSP: 893).
} 
de Música Brasileira e dirigiu a Revista Brasileira de Música, atividade por meio da qual também manteve correspondência com Mário de Andrade, em seu papel de colaborador da revista.

Quando Luiz Heitor Corrêa de Azevedo tinha 34 anos, já então amigo de Mário de Andrade, ocupou a primeira cadeira de folclore da então Escola Nacional de Música da Universidade do Brasil. Na biblioteca de Mário de Andrade, encontrase um exemplar do trabalho com o qual Corrêa de Azevedo concorreu a esse cargo, intitulado Escala, ritmo e melodia na música dos índios brasileiros (1938). O exemplar tem inúmeras notas marginais feitas por Mário de Andrade, nas quais se percebe seu desacordo em relação a alguns pontos da argumentação.

Sua maior discordância foi sobre a inexistência de quartos de tom na música indígena, assinalados por Corrêa de Azevedo. Criticou o uso constante de métodos de análise musical tomados da teoria ocidental que — de acordo com Mário de Andrade - levaram o autor a forçar os exemplos musicais à lógica das escalas e modos europeus ${ }^{63}$. Assim, questionou a veracidade das fontes que Corrêa de Azevedo havia estudado $^{64}$ e não concordou com a hierarquia que ele estabeleceu em seu livro ${ }^{65}$. Também escreveu que não entendia por que o autor não outorgara o conceito de compasso à música indígena, se havia concluído que a organização rítmica era idêntica a ocidental ${ }^{66}$.

No mesmo ano do concurso, Mário de Andrade escreveu no jornal Estado do S. Paulo um pequeno artigo, intitulado "Quarto de tom", no qual, a partir do trabalho de Corrêa de Azevedo, discutiu com moderação o que era um quarto de tom e sua presença na música indígena, sem mencionar seus desacordos com o trabalho do jovem músico ${ }^{67}$. Comparando-se os fortes comentário deixados em seu exemplar com o tom do artigo publicado, mais calmo e pedagógico, faz pensar que Mário de Andrade achou desnecessário criticar publicamente o autor, preferindo apresentar

\footnotetext{
63 Em uma nota à margem, Mário de Andrade deixou escrito: "Na realidade foi inútil na p. 22 dizer que não supunha tonalidade nem modos, pois durante todo o livro pensa tonal, modal e harmonicamente. Como aqui puxando que um determinado som da escala é o quinto grão". (Andrade, Nota marginal. In: Azevedo, Luiz Heitor Correia de. Escala, ritmo e melodia na música dos indios brasileiros. Rio de Janeiro: Typ. do "Jornal do Commercio" Rodrigues \& cia., 1938, p. 33).

${ }^{64}$ Andrade, Nota marginal, In: ibid., p. 30.

${ }^{65}$ Andrade, Nota marginal, In: ibid., p. 32.

${ }^{66}$ Andrade, Nota marginal, In: ibid., p. 47.

${ }^{67}$ Andrade. "Quarto de tom." [1939] Música, doce música. Estudos da crítica e folclore.
} 
suas indagações sobre a presença de quartos de tom na música indígena, deixando ao leitor mais cuidadoso a tarefa de descobrir sua posição contrária.

Dois anos após assumir o cargo de professor da cadeira de folclore, Corrêa de Azevedo foi convidado pela União Pan-americana para ser cônsul na Divisão de Música em Washington (USA) durante seis meses. Da capital estadunidense, continuou sua correspondência com Mário de Andrade, depois de um convite feito ao escritor paulista por Charles Seeger, musicólogo norte-americano e diretor da Divisão de Música, para proferir algumas palestras sobre música nos Estados Unidos $^{68}$.

Outro fato que também motivou o intercâmbio de cartas entre os dois brasileiros foi a viagem que Allan Lomax, diretor da seção Arquive of American Folk Song da Biblioteca do Congresso em Washington, planejava fazer ao Brasil para compilar música folclórica, e a quem Luiz Heitor Corrêa de Azevedo estava ajudando a organizar seu trabalho. Essa viagem acabou não se realizando por causa da entrada dos Estados Unidos na Segunda Guerra Mundial, de modo que Corrêa de Azevedo foi encarregado de fazer o registro do material no ano seguinte. O músico brasileiro foi também autorizado a deixar uma cópia desse material na Escola Nacional de Música e outra na Biblioteca do Congresso nos Estados Unidos ${ }^{69}$.

A responsabilidade por essa excursão, de claro viés folclórico, motivou Corrêa de Azevedo a convidar Mário de Andrade a participar, mas, ao que parece, recebeu uma resposta negativa de nosso autor. É possível pensar que o papel de Mário de Andrade tenha-se limitado a responder algumas perguntas sobre o lugar para onde Corrêa deveria viajar, a fim de não coincidir com os territórios percorridos antes pela Missão de Pesquisas Folclóricas do Departamento de Cultura ${ }^{70}$. Finalmente, a viagem foi realizada no início de 1943 por Corrêa de Azevedo em companhia de Eurico Nogueira França. Em carta enviada de Fortaleza a Mário de Andrade, ele conta que foram gravados 75 discos de música registrada no Ceará, Pernambuco, Paraíba e Rio Grande do Norte ${ }^{71}$.

\footnotetext{
${ }^{68}$ Carta de Luiz Heitor Corrêa de Azevedo, Washington, 8 set. 1941. IEB-USP: 921.

${ }^{69}$ Carta de Luiz Heitor Corrêa de Azevedo, RJ, 25 mar. 1942. IEB-USP: 923.

${ }^{70}$ Carta de Luiz Heitor Corrêa de Azevedo, RJ, 9 nov. 1942. IEB-USP: 926.

${ }^{71}$ Carta de Luiz Heitor Corrêa de Azevedo, Fortaleza, 25 fev. 1943. IEB-USP: 928.
} 
De acordo com José Geraldo Vinci de Moraes e Cacá Machado, a coleção de música gravada nessa viagem converteu-se no mais importante e abrangente arquivo de música popular folclórica, junto com aquele que foi registrado pela Missão de Pesquisas Folclóricas do Departamento de Cultura cinco anos antes ${ }^{72}$. Talvez essa experiência em campo, somada a tentativas anteriores de consolidar uma associação em torno dos estudos folclóricos ${ }^{73}$, tenha levado Corrêa de Azevedo a fundar, em 1943, o Centro de Pesquisas em Folclore na Escola Nacional de Música da Universidade do Brasil. Esse centro tem sido considerado o primeiro do país, mas sua atividade debilitou-se com a partida de seu fundador para a França, em 1951. Em 1945, ano da morte de Mário de Andrade, Luiz Heitor Corrêa de Azevedo encontrava-se ainda no Brasil, trabalhando como colaborador do periódico A Manhã, do Rio de Janeiro.

Entre os escritos que Luiz Heitor Corrêa de Azevedo publicou quando Mário de Andrade vivia, encontram-se em sua biblioteca Dois pequenos estudos de folclore musical (1938), com dedicatória do autor e sem indícios de uma leitura detalhada $^{74}$. Esse livro é ilustrativo do ambiente intelectual de que Corrêa de Azevedo desfrutou em sua juventude. Consiste na publicação de duas "palestras radiofónicas" proferidas em 1936 e 1937 no Departamento Nacional de Propaganda (Hora do Brasil) e na Rádio Cruzeiro do Sul. Na primeira, o autor usou o termo folcmúsica, pela necessidade que possivelmente sentiu de diferenciar a música

${ }^{72}$ Moraes e Machado. "«Música em conserva»: memória e história da música no Brasil." La memoria histórica y sus configuraciones temáticas. Una aproximación interdisciplinaria, p. 12.

$73 \mathrm{Na}$ correspondência entre Mariza Lira e Mário de Andrade, lê-se que houve tentativas anteriores de associação por parte dos folcloristas cariocas que, desde 1940, vinham negociando a criação de uma comissão com o governo de Getúlio Vargas. Mariza Lira informava Mário de Andrade sobre o curso da negociação e, em 1942, anunciou que o Instituto Brasileiro de Folklore seria inaugurado em setembro do mesmo ano, e presidido por Basílio Magalhães. Não se sabe se esse Instituto concretizou-se no Centro de Pesquisa em Folclore da Escola Nacional de Música, inaugurado em 1943, ou se era uma instância diferente (Carta de Mariza. [RJ], 21 de julho de 1942. IEB-USP: 4240).

${ }^{74}$ Outros textos publicados por Corrêa de Azevedo, em vida de Mário de Andrade, e cujos exemplares conservam-se em sua biblioteca, são: Azevedo, Luiz Heitor Corrêa de. Saudação a o Lorenzo Fernandez. Rio de Janeiro: Conservatório Brasileiro Música, 1937, e Azevedo, Luiz Heitor Correia de. Relação das óperas de autores brasileiros. Rio de Janeiro: Serviço gráfico do Ministério de Educação e Saude, 1938.

Na biblioteca também se encontra, sem notas marginais, o curto artigo "Folclore in the Music Curriculum in Brazil", no qual Corrêa de Azevedo sintetiza o processo de institucionalização desses estudos, começando com os trabalhos de Mário de Andrade e terminando com a cadeira de folclore, ocupada por ele. Ver: Azevedo, Luiz Heitor Correia de. "Folklore in the Music Curriculum in Brazil." Music Teachers National Association. (1941). 
popular, definida pelo folclore, de outra música popular que se ouvia nas cidades e que era considerava como antítese da primeira, como se verá no terceiro capítulo.

Além disso, nesse texto, Corrêa de Azevedo fez um breve resumo da história e situação musical de vários países latino-americanos, usando os trabalhos de outros pesquisadores como do argentino Carlos Vega, do chileno Carlos Isamit, do colombiano Emirto de Lima, dos peruanos Andrés Sas e Carlos Raygada, além de se valer dos dois volumes, até o momento publicados, do Boletín Latinoamericano de Música, editado por Francisco Curt Lange ${ }^{75}$. Com seu escrito, percebe-se que Corrêa de Azevedo usou a rede de contatos tecida em torno de Lange e que conhecia bastante bem os trabalhos de seus colaboradores.

A relação entre Mário de Andrade e Luiz Heitor Corrêa de Azevedo parece difícil de ser vislumbrada a partir de sua correspondência, pois, ao que parece, eles tiveram outros contatos que reforçaram a confiança que o escritor paulista expressou pelo jovem músico carioca. Chama a atenção o fato de que, do ponto de vista acadêmico, e de acordo com o mesmo Corrêa de Azevedo, seus trabalhos publicados enquanto o escritor paulista vivia foram escritos rápidos que se apresentaram como coletas de informação feitas sem a profundidade que cada tema exigia ${ }^{76}$.

Uma exceção a essa superficialidade foi o trabalho sobre música indígena mencionado, do qual, ao que parece, Mário de Andrade não gostou em sua totalidade. Talvez, o principal defeito achado pelo escritor paulistano pudesse ser resumido na forte ligação do pensamento de Corrêa de Azevedo com a tradição musical europeia, a qual não o deixou pensar a música indígena em sua estrutura própria.

Assim como Renato de Almeida, Luiz Heitor Corrêa de Azevedo interessouse pela chamada música popular desde jovem, não obstante fosse um tema desdenhado na academia. Ainda que tivesse uma formação musical mais robusta em comparação à de Renato de Almeida, Corrêa de Azevedo manteve ligação com o folclore e seu conceito de música popular parece baseado no pensamento romântico do qual o folclore era herdeiro. Nesse tema, voltar-se-á no segundo capítulo.

\footnotetext{
${ }^{75}$ Azevedo, Luiz Heitor Correia de. Dois pequenos estudos de folclore musical. Rio de Janeiro: Typ. do "Jornal do Commercio" Rodrigues \& cia., 1938.

${ }^{76}$ Essas observações foram feitas pelo próprio Luiz Heitor Corrêa de Azevedo nas introduções de seus textos Relação das óperas de autores brasileiros (1938) e Dois pequenos estudos de folclore musical (1938).
} 


\subsection{A admiração de uma mulher}

Mariza Lira é uma figura interessante da historiografia musical porque lhe é atribuído o papel de pioneira nos estudos de música popular urbana do Brasil ${ }^{77}$. Seus primeiros trabalhos são um pouco posteriores aos livros dos jornalistas e cronistas Alexandre Gonçalves Pinto (Animal), Orestes Barbosa e Francisco Guimarães (Vagalume), também interessados em documentar fenômenos musicais urbanos do Rio de Janeiro. Não obstante, é provável que Marisa Lira tenha ganhado maior reconhecimento por ter pertencido a uma elite intelectual que legitimou sua carreira como pesquisadora. Além de ter mantido contato com Mário de Andrade ao final de sua vida, também se relacionou com outros acadêmicos como Luiz Heitor Corrêa de Azevedo, Brasílio Itiberê e Renato de Almeida.

Ao que parece, os trabalhos da Mariza Lira estiveram mais próximos do folclore, em geral, do que da pesquisa propriamente musical, pois, ao mesmo tempo que estudou expressões musicais, ela também dedicou tempo a outros aspectos culturais como festas, literatura popular, culinária e cerâmica. Uma amostra de seus vários interesses encontra-se na recopilação de alguns de seus artigos no livro Migalhas folklóricas $(1951)^{78}$.

Em especial, em seus textos sobre música, foram notórias as menções a fenômenos musicais urbanos sem tom de menosprezo. Ela foi um dos poucos autores consultados a fazer comentários ocasionais à música que circulava nos filmes nacionais e estrangeiros da época, com o que se percebe que seus ouvidos prestaram atenção a mais âmbitos urbanos por onde circulou a música das cidades, do que os ouvidos de muitos de seus colegas.

Assim como na maioria dos autores estudados, não foi encontrada uma definição exata de música popular nos escritos de Mariza Lira; sem embargo, foi chamativa uma rápida alusão ao popular. Com popular, Lira pareceu referir-se a algo próprio das pessoas pobres, em contraposição aos "abastados senhores", menção esboçada muito rapidamente ao se referir aos bailes pastoris: "Não eram propriamente populares, porque o presépio, e os bailes só se realizavam em

\footnotetext{
${ }^{77}$ Moraes, José Geraldo Vinci de. "O Brasil sonoro de Mariza Lira." Temas \& Matizes. no. 10 (2006).

${ }^{78}$ Lira, Mariza. Migalhas folklóricas. Rio de Janeiro: Gráfica Laemmert Ltda, 1951.
} 
residências de abastados senhores..."79. Essa apreciação foi matizada no ano seguinte em um curto artigo, intitulado "O folklore no quadro das ciências antropológicas", no qual a autora escreveu que "não se pode admitir apenas como objeto do folclore a cultura das classes populares. Na verdade é aí que encontramos em maior número, os fatos folklóricos, mas também os encontramos nas chamadas classes cultas" $" 80$. Tudo indica que, embora Mariza Lira tenha incluído em seus trabalhos referências ao âmbito musical urbano, isso não tenha partido de uma definição ampla de música popular, já que sobressai em seus escritos um pensamento mais ligado ao folclore europeu e ao naturalismo ${ }^{81}$.

Por outro lado, pouco se conhece da formação musical ou em pesquisa de Mariza Lira. Mas, graças à correspondência que manteve com Mário de Andrade, sabe-se que ela fez cursos de teoria e solfejo, embora considerasse que suas ferramentas não fossem suficientes para estudar com eficiência o material musical ${ }^{82}$. Também atribuiu ao autor paulistano, e seus livros, seu entusiasmo por estudar o folclore $^{83}$, e em 1941 mencionou os nomes de Alberto de Oliveira, Rocha Pombo e Bricio Filho como seus "mestres queridos", provavelmente porque admirava e aprendia de seus escritos. Em suas missivas, Mariza Lira chamava Mário de Andrade de "professor" e, quando the confessou certa desilusão com o estado dos estudos de folclore em seu país, resgatou o trabalho de uns poucos:

Fico a pensar, porem, como varias alunas que tenho tido dos cursos oficiais, conseguiram com essas notas aprovações destrutivas. Disso e das discussões confusas e discordantes das nossas reuniões, chego a crer, que o folclore no Brasil ainda está a jogar cabeça-cega, salvo poucos nomes que acato - Mario de Andrade, Basilio de Magalhães, Lindolfo Gomes e pouquíssimos mais ${ }^{84}$.

Parece que Mariza Lira procurou constantemente o apoio e o conselho de Mário de Andrade em matéria de pesquisa e em relação à criação do Instituto de

79 Lira, Mariza. Brasil sonoro. Generos e compositores populares. Rio de Janeiro: S. A. A. Noite, 1938, p. [49].

80 Lira, Mariza. "O folklore no quadro das ciências antropolôgicas." [1939] Migalhas folklóricas, Rio de Janeiro: Gráfica Laemmert Ltda, 1951, p. 11.

${ }^{81}$ Ver: Moraes. "O Brasil sonoro de Mariza Lira.".

${ }^{82}$ Carta de Mariza Lira, RJ, 30 jun. 1941. IEB-USP: 4232.

83 “O sr. nem sabe o quanto lhe devo. Na minha semi-inconsciência de doente, ganhei o seu «Ensaio sobre a nossa música popular». Achei tal encanto em tudo que ali havia! Comecei admira-lo e a querer-lhe bem" (Carta de Mariza Lira, RJ, 11 jul. 1941. IEB-USP: 433). Também fez referência à motivação que encontrou na obra de Mário de Andrade (Carta de Mariza Lira, RJ., [ant. set. 1940]. IEB-USP: 4225).

${ }^{84}$ Carta de Mariza Lira, RJ, 30 jun. 1941. IEB-USP: 4232. 
Folclore, pela qual vinha lutando no Rio de Janeiro ${ }^{85}$. Em tais cartas, Mariza Lira escrevia a Mário de Andrade acerca dos temas que estava trabalhando ${ }^{86}$. Enviou-lhe escritos em rascunho para conhecer sua opinião antes de serem publicados ${ }^{87}$, convidou-o a sua casa e a saídas de terreno para compartilhar material folclórico ${ }^{88}$, enviou-lhe seus livros e as partituras que considerou que podiam-lhe interessar ${ }^{89}$, pediu-lhe conselho para desenvolver seus trabalhos ${ }^{90}$ e o manteve a par de uma exposição de objetos folclóricos realizada em 1941, no Rio de Janeiro ${ }^{91}$.

Uma das primeiras cartas conservadas e assinadas por Mariza Lira foi escrita em dezembro de 1938. Nessa carta, percebe-se que os dois pesquisadores tinham conhecido-se pessoalmente pouco tempo atrás, apesar de Mariza Lira já conhecer anteriormente a produção do famoso escritor a quem tinha citado como "pesquisador admirável de minúcias musicais" $"$

Durante a vida de Mário de Andrade, Marisa Lira publicou vários livros. O primeiro foi intitulado Brasil sonoro. Generos e compositores populares (1938), no qual reuniu um grande número de gêneros musicais brasileiros, exemplificados por meio dos textos, sem partitura ${ }^{93}$. A julgar pela correspondência, parece que os dois autores conversaram sobre esse livro, mas o chamavam por outro título: em várias cartas posteriores a 1938, foi mencionado um escrito em revisão com o título de "Brasil Folclórico" que, talvez, tratasse-se de uma segunda edição do livro Brasil sonoro.

${ }^{85}$ Cartas de Mariza Lira: RJ, 16 set. 1940 (IEB-USP: 4226); 12 mar. 1941 (IEB-USP: 4227); 4 abr. 1941 (IEB-USP: 4228); 28 nov. 1941 (IEB-USP: 4237) e 21 jul. 1942 (IEB-USP: 4240).

${ }^{86}$ Refere-se a sua participação em um programa de radio e lhe pede conselho sobre os temas de que trataria (Carta de Mariza Lira, RJ, [ant. set. 1940]. IEB-USP: 4225).

${ }^{87}$ Carta de Mariza Lira, Curitiba, [ant. 20 fev. 1943]. IEB-USP: 4241.

De acordo com a base de dados do Arquivo do IEB, na série Manuscritos de Vários Autores encontra-se o trabalho manuscrito Folclore do Paraná, de Mariza Lira, o qual provavelmente acompanhou a carta referida. Esse escrito pode ser a base de uma conferência que Mariza Lira proferiu em 5 de janeiro de 1943 em Curitiba, e que enviou a Mário de Andrade cinco dias antes.

${ }^{88}$ Carta de Mariza Lira, RJ, 12 mar. 1940. IEB-USP: 4224.

89 Envio de Brasil Sonoro (Carta de Mariza Lira. RJ, 5 dez 1939. IEB-USP: 4222). Envio de partituras de choro (Carta de Mariza Lira, RJ, 12 mar. 1940. IEB-USP: 4224).

${ }^{90}$ Carta de Mariza Lira, Curitiba, 4 mar. 1942. IEB-USP: 4239.

${ }^{91}$ Cartas de Mariza Lira, RJ, [ant. 30 jun. 1941]. IEB-USP: 4231; RJ, 30 jun. 1941. IEB-USP: 4232; RJ, 15 set. 1941. IEB-USP: 4235.

${ }^{92}$ Lira. Brasil sonoro. Generos e compositores populares. p. 75.

93 Ibid. O exemplar que pertenceu a Mário de Andrade tem um par de notas nas margens, assinalando um verso que possivelmente usaria em seu trabalho "O seqüestro da Dona Ausente" e uma correção tipográfica na impressão. 
A propósito de dito manuscrito, Mariza Lira agradeceu a Mário de Andrade os comentários que este fez a esse escrito, assegurou ter trabalhado novamente sobre ele e o enviou, em junho de 1941, em uma nova versão para que Mário de Andrade fizesse observações, antes de enviá-lo ao editor. Por uma carta de um mês depois, em que Mariza Lira agradece a Mário de Andrade por todas as suas correções, conclui-se que o referido manuscrito chegou ao escritor paulista e retornou à sua autora ${ }^{94}$. Entretanto, não se conhece a publicação de um novo trabalho sob o título de "Brasil folclórico", nem uma segunda edição de seu livro Brasil sonoro.

Em 1939, quatro anos após a morte da Chiquinha Gonzaga, Mariza Lira publicou uma das primeiras biografias da compositora, com a qual ganhou reconhecimento em sua época. A propósito dessa biografia, Mário de Andrade escreveu um breve artigo no qual advogou pelo estudo da música popular urbana e felicitou Mariza Lira pelo livro. Além disso, sublinhou que uma possível origem da palavra maxixe tinha sido comentada por ele em um trabalho anterior e Mariza Lira, além de não citá-lo, tomou sua hipótese como verídica, sem mencionar as reservas que ele tinha apresentado no momento de sua publicação ${ }^{95}$.

Com um trato respeitoso e carinhoso, Mariza Lira esclareceu em uma carta que, por ser muito conhecido o trabalho em que Mário de Andrade fazia tal afirmação, não o citara assim como não costumava citar nenhum outro autor.

Sobre o caso de maxixe não me referi ao seu nome, primeiro porque por principio não me refiro a autor algum. Sem ha contestaças (sic) aponto a fonte onde colhi o assunto. Segundo, porque não ha quem se interesse por música ou folclore que não conheça a sua referência ${ }^{96}$.

Ao que parece, Mário de Andrade, em resposta a essa carta, fez sugestões de estudo sobre o maxixe, pois, na seguinte missiva, Mariza Lira diz que achou “...

94 "Finalmente aqui está o meu Brasil Folclórico. Apresento-o como uma prova de aluna ao mestre. Como verá não tive intenção de apresentar um documentário e sim um livro didático que talvez seja útil aos estudioso do folclore. Gostaria que me julgasse severamente. Peço-lhe ainda um favor, que a faça tão depressa quanto possível, por causa do editor. Desde já e de qualquer forma os meus agradecimentos." (Carta de Mariza Lira, RJ, 6 jun. 1941. IEB-USP: 4230).

Em 30 de junho e em novembro do mesmo ano, Mariza Lira agradeceu os comentários feitos ao manuscrito (Cartas de Mariza Lira, RJ, 30 jun. 1941. IEB-USP: 4232, y 28 nov. 1941. IEB-USP: 4237).

95 Andrade. "Chiquinha Gonzaga." [1940] Música, doce música. Estudos da crítica e folclore. No exemplar do livro resenhado e que pertenceu a Mário de Andrade, está escrita essa mesma observação na capa do livro. No interior há diversos traços que ressaltam fatos da vida da compositora; algumas menções e precisões sobre suas obras mais conhecidas, e comentários sobre os gêneros populares como o tango, o maxixe e a polca.

${ }^{96}$ Carta de Mariza Lira, RJ, 6 mar.1940. IEB-USP: 4223. 
ótima a incumbência que o Sr. me deu de desvendar o caso do maxixe. Farei o possível para chegar a um resultado positivo"97.

Por outra parte, Mário de Andrade não separou sua paixão pela música da sua paixão pela literatura, e é uma constante em sua obra um cruzamento entre esses dois amores. Algumas vezes, seus conhecimentos de música alimentaram sua obra literária e, outras vezes, seus dotes de literato permearam seus trabalhos em pesquisa musical ${ }^{98}$. Portanto, ao estudar as notas marginais que o autor deixou nos volumes de sua biblioteca, é importante ter em conta que, nem todas as vezes que leu um livro sobre música, suas notas foram feitas para alimentar seus trabalhos musicais. Como acontece no livro sobre Chiquinha Gonzaga, observam-se traços que provavelmente procuraram ressaltar usos da linguagem nas letras das canções, anedotas com valor criativo e demais materiais que pudessem alimentar seus trabalhos como literato e artista.

Parece que, por volta de 1941, a única filha da Mariza Lira casou-se com um oficial de cavalaria e foram viver em Castro, no Paraná ${ }^{99}$. É possível que, por esse motivo, a autora carioca tenha começado a frequentar o Sul do Brasil e, talvez pela conexão de seu genro com o exército, tenha publicado a coleção Cânticos militares (1942), em que reuniu as letras de 90 hinos com suas respectivas melodias ${ }^{100}$.

Na terceira seção desse livro, Mariza Lira incluiu uma resenha escrita pelo major Alberto Martins sobre a "canção do soldado paulista", na qual o major — autor da letra do hino - disse que o título de tal marcha não incluía a palavra "paulista" porque não se pretendia referir somente aos soldados daquela região. Mário de Andrade, em uma nota à lápis na margem de seu exemplar, escreveu "A Marselhesa também não nasceu pros marselheses, a «canção do soldado paulista» foi adotada e fez sucesso aqui e depois se espalhou. É ou que é"101.

${ }^{97}$ Carta de Mariza Lira, RJ, 12 mar. 1940. IEB-USP: 4224.

98 Gilda de Melo Souza, por exemplo, estudou a influência musical em seu livro Macunaíma (Mello e Souza, Gilda de. O tupi e o alaúde. São Paulo: Duas cidades, 1979).

${ }^{99}$ Carta de Mariza Lira, Castro, 24 dez. 194. IEB-USP: 4238.

${ }^{100}$ Lira, Mariza. Cânticos militares. Rio de Janeiro: Imprensa Nacional 1942.

${ }^{101}$ Andrade, Nota marginal, In: Ibid., p. 79. 
Dois anos depois de publicado o livro de Mariza Lira, Mário de Andrade publicou uma série de quatro artigos intitulada "Músicas políticas" em sua coluna Mundo Musical da Folha da Manhã. Ali, fez menção ao caso da "Canção do Soldado Paulista" e reproduziu o mesmo argumento escrito no exemplar de seu livro ${ }^{102}$.

Este foi o único comentário encontrado de Mário de Andrade sobre a publicação de Mariza Lira. Não obstante, pela correspondência entre eles, parece que o autor sugeriu mais reparos, pois Mariza escreveu-lhe em 1943:

Já sei que achou minha conferência cheia de falhas. Muitas delas não tive nem tenho culpa. Como ha um decreto proibindo os hinos estaduais, não me foi possível publicar o 2 de julho e outros. Foram cortados como outros tantos, pelas comissões selecionadoras. Havia perto de 300 hinos / músicas e letras e uns cento e cincoenta sem música. No fim só apareceram esses. Trata-se de uma publicação de um Ministério. Em fim salvo-se alguma cousa. Ha oficiais que não gostaram que aparecessem certas canções meio pobres de música e letra. Mas, não fui eu quem as fez. Demais estão enraizadas nas casernas, foram escolhidas. Como é difícil agradar a muitos... ${ }^{103}$

No ano anterior à morte de Mário de Andrade, Mariza Lira publicou sua conferência Posição de João Ribeiro no folklorismo nacional (1944) e enviou um exemplar a São Paulo. Não se sabe quais foram as impressões de Mário de Andrade acerca desse escrito porque, ainda que tenha sido catalogado em sua biblioteca, não dá amostras de ter sido lido.

Depois da morte de Mário de Andrade, Lira continuou publicando seus trabalhos sobre folclore musical e foi notória a sua participação na Revista de Música Popular (1955-1956). Em 1966, foi convidada pelo primeiro diretor do Museu da Imagem e do Som para integrar o Conselho Superior da MPB (música popular brasileira). Mariza Lira, nascida no Rio de Janeiro, realizou seus trabalhos de pesquisa juntamente com a carreira docente, pois, após se graduar pela Escola Normal, trabalhou como diretora de uma escola técnica secundária em sua cidade natal.

102 Andrade, Mário de. "Músicas políticas I." [1943] In: Jorge Coli (ed.), Música final. Mário de Andrade e sua coluna jornalística Mundo musical, Campinas: Editora da Unicamp, 1998.

${ }^{103}$ Carta de Mariza Lira, Curitiba, 20 fev. 1944. IEB-USP: 4242. 


\section{Mário de Andrade e o ambiente latino-americano}

A atividade musical latino-americana do século XIX foi comentada nos vários periódicos que eram publicados nas cidades e, entre essas resenhas, notícias, artigos, reclamações, cumprimentos e críticas feitas aos músicos e compositores, forjou-se um corpo literário que pode ser considerado como antecedente da nossa tradição historiográfica. Exemplos das primeiras histórias musicais são o artigo do compositor Juan Crisóstomo Osorio (1836-1887), "Breves apuntamientos para la historia da la música en Colômbia" (1879), e os livros La música ecuatoriana desde su origen hasta 1875 (1876), do músico e diretor do conservatório Juan Agustín Guerrero Toro (1818-1886); a Historia de la música guatemalteca desde la monarquía española hasta fines del año ano 1877 (1878), de José Saenz, possível integrante de uma família de músicos de capela; Ensayos sobre el arte en Venezuela (1883), do violoncelista Ramón de la Plaza (1831-1886) e Las artes en Santiago de Cuba (1893), do compositor Laureano Fuentes Matons (1825-1898).

Graças ao auge do nacionalismo musical de inícios do século XX, houve no continente um aumento de trabalhos histórico-musicais que buscavam legitimar alguns aspectos musicais, por meio do relato histórico. Segundo suas argumentações, certos gêneros e instrumentos musicais de seus países faziam parte de uma tradição antiga e tinham o potencial necessário para servir de base para a conformação do repertório nacional almejado. Exemplos disso são as argumentações de livros como A música no Brasil desde os tempos coloniais até o primeiro decênio da república (1908), do bibliotecário Guilherme Theodoro Pereira de Mello (1867-1932); El folklore y la música mexicana (1928) do escritor Rubén Campos (1871-1945); Del folk-lore musical dominicano (1927), do regente porto-riquenho Julio Arzeno (1892-1932) e o artigo "La música en el Ecuador" (1930), do compositor e regente Segundo Luis Moreno (1882-1972).

Pela escassa circulação que tiveram os textos citados, não é de se estranhar que o único que se encontre na biblioteca de Mário de Andrade seja a história de seu conterrâneo, Guilherme Theodoro Pereira do Mello e, casualmente, uma parte do livro do venezuelano Ramón de la Plaza, que foi reimpresso em 1919 dentro do livro 
Musicologia latino-americana. A música popular e os músicos célebres da América Latina, do músico argentino Lucas Cortijo Alahija.

\subsection{Francisco Curt Lange e a primeira rede musicológica}

Em linhas gerais, esse era o meio intelectual que prevalecia quando chegou o jovem alemão Francisco Curt Lange para morar no Uruguai na década de 1920, e para fazer da atividade musical americana sua principal preocupação. Uma de suas primeiras providências foi entrar em contato com todos os músicos, compositores e intelectuais que estavam trabalhando com música no continente, a fim de organizar e institucionalizar uma rede de intercâmbio e apoio musical sob sua coordenação. Em 1933, fundou a Sección de Investigaciones Musicales no Instituto de Estudios Superiores de Investigações do Uruguai com o objetivo de liderar seis projetos de proporções continentais:

1. Investigaciones y publicaciones. Léxico latinoamericano de música.

2. Biblioteca latinoamericana de música.

3. Discoteca de obras latinoamericanas.

4. Museo latinoamericano de instrumentos indígenas, partituras y demás documentos.

5. Boletín latinoamericano de música.

6. Organización del Congreso latinoamericano de música ${ }^{104}$.

Sua proposta, resumida sob a insígnia "americanismo musical”, conjugava dois problemas relevantes para a época: identidade e pan-americanismo. Lange conseguiu ser bem-vindo em todos os países onde procurou apoio financeiro e humano para a realização de seus titânicos propósitos, e acabou por se converter na cabeça visível da primeira rede de intercâmbio de conhecimento musical latinoamericana.

Embora na vida intelectual de Lange seus principais escritos não versassem sobre música popular ou folclórica, sua figura é relevante para a história do conceito

104 Lange, Francisco Curt. Americanismo musical. Montevideo: Instituto de estudios superiores República Oriental de Uruguay, 1934, p. 17. 
música popular por sua dedicação na gestão e edição de publicações ${ }^{105}$. Seu papel foi particularmente importante como ponte de comunicação entre vários estudiosos da música popular por meio do Boletín Latinoamericano de Música, de suas cartas e pela vontade de pôr em contato pessoas afins. Do Boletín, fez parte uma grande quantidade de autores, alguns já conhecidos por Mário de Andrade, por meio de seus livros, ou mediante correspondência, como o colombiano Emirto de Lima, o chileno Domingo Santa Cruz, os mexicanos Rubén M. Campos e Vicente T. Mendoza, e o espanhol Otto Mayer-Serra. Uma amostra do empenho de Lange em criar uma rede foi a publicação, nos tomos do Boletim, de fotografias com os rostos de quem estava desenvolvendo atividades relacionadas com pesquisa musical, todas solicitadas por correspondência a seus donos com dedicatória a ele.

Não passou muito tempo para que Francisco Curt Lange tomasse conhecimento das atividades intelectuais de Mário de Andrade e procurasse entrar em contato com ele. Em 1932, o musicólogo alemão apresentou-se como:

...profesor de Ciencias musicales, habiendo estudiado en Europa con [Arthur] Nikisch y otros maestros. Actualmente me encuentro al frente de la Discoteca Nacional del Servicio Oficial de Difusión Radio Eléctrica y de la Biblioteca musical de este organismo, habiendo sido llamado para tal causa por el Gobierno del país. A la vez desempeño el cargo de Catedrático de Historia estética de la música en la Universidad ${ }^{106}$.

Francisco Curt Lange, 10 anos mais jovem que Mário de Andrade, tinha chegado a viver em Montevidéu em 1923, depois de se formar arquiteto e musicólogo na Alemanha ${ }^{107}$. Na primeira carta que escreveu ao escritor paulista, Lange assegurou que conheceu Mário de Andrade por meio da leitura de seu livro Ensaio sobre a música brasileira (1928), livro este que causou sua "entera satisfacción" pelo "procedimiento honesto y el trabajo serio" ali desenvolvidos. Também contou que, por meio de Ildefonso Pereda Valdés - escritor uruguaio com

${ }^{105}$ A importância de Francisco Curt Lange para a pesquisa musical brasileira está ligada a seus trabalhos sobre a música do período colonial, mas esta é uma faceta da qual não nos ocupamos por ter sido desenvolvida em um período posterior ao estudado, e distante de nosso foco temático. De acordo com Luis Merino, foi nos anos de 1944 e 1946 — por volta do ano da morte de Mário de Andrade que Francisco Curt Lange iniciou suas pesquisas em Minas Gerais, sobre a música do período colonial brasileiro (Merino. "Francisco Curt Lange (1903-1997): tributo a un americanista de excepción.").

106 Carta de Francisco Curt Lange, Montevideo, 20 nov. 1932. IEB-USP: 3894.

107 Os dados sobre sua formação e estudos na Alemanha são fornecidos pelos seus biógrafos, repetindo a informação que Francisco Curt Lange deu em vida, e se teme que ele tenha exagerado em relação a seus inúmeros títulos quando se pensa que eles teriam sido obtidos antes dos 20 anos, idade com que Lange chegou em Montevidéu. 
quem Mário de Andrade também manteve correspondência —, soube que estava escrevendo uma história da música e que, na sua opinião, fazia falta uma história de boa qualidade na América Latina ${ }^{108}$. Finalizou sua carta convidando Mário de Andrade a participar de um projeto que tinha em mãos, ao qual chamava de "léxico musical sul-americano" e estava relacionado com seu trabalho como colaborador do musicólogo alemão Alfred Einstein, editor do Dicionário Riemann ${ }^{109}$.

Assim teve início, entre os dois personagens, um intercâmbio epistolar que produziu mais de 50 cartas assinadas por Francisco Curt Lange. Nelas, não se aprofundou em temas acadêmicos, exceto por informação solicitada por Lange sobre o pianista norte-americano Louis Moreau Gottschalk, e se limitou ao intercâmbio de bibliografia com comentários gerais ${ }^{110}$. Sem embargo, suas cartas refletem a troca de informação relacionada a músicos e instituições brasileiras, notícias sobre os trabalhos que ambos realizavam, pedidos de partituras para pôr em circulação música de compositores brasileiros, apresentação de amigos e músicos, solicitações de Lange para ser convidado como conferencista remunerado em São Paulo e um grande silêncio em torno do "americanismo musical", lema político de Lange.

Com 29 anos de idade e com certa prepotência, Francisco Curt Lange dá a impressão, em suas primeiras cartas, de querer converter Mário de Andrade em seu braço direito no Brasil, buscando sua colaboração mediante uma exaltação de seus próprios méritos acadêmicos. Mas parece que esses méritos não impressionaram muito o escritor paulistano. Desde a primeira carta, o musicólogo alemão pediu a Mário de Andrade o envio por correio registrado de dados biográficos de músicos e

108 Francisco Curt Lange opinava sobre as histórias da música: "De ediciones sudamericanas, o mejor dicho, de las pocas ediciones que conozco, ninguna me ha gustado. Entre ellas figura una de un señor [Mariano Antonio] Barreneche, argentino, que es muy mala. Un resumen de muchos libros europeos, y nada más. Una simple recopilación de datos, falta de una nota personal y además, esto es lo más importante, el citado señor carece de bases musicales. Existe en Buenos Aires un Profesor en Historia musical de mucho valor, un intelectual de primera agua, el señor Ernesto de Laguardia, quien está también empeñado en escribir una Historia de la música." (Carta de Francisco Curt Lange, Montevideo, 20 nov. 1932. IEB-USP: 3894).

109 Mário de Andrade conhecia bem esse dicionário, pois, além de citá-lo em seus trabalhos, sua biblioteca conserva a edição francesa de 1913 (Dictionnaire de musique) e a $11^{\mathrm{a}}$ edição alemã, editada por Alfred Einstein (Hugo Riemanns Musik Lexikon).

110 Em 1943 e 1944, Francisco Curt Lange contou a Mário de Andrade que estava fazendo um trabalho biográfico sobre Louis Moreau Gottschalk e lhe pediu informação sobre ele (Cartas de Francisco Curt Lange, Montevideo, 24 abr.1943. IEB-USP: 3937; RJ, 3 jun. 1943. IEB-USP: 3938; RJ, 21 ene. 1944. IEB-USP: 3939). Em 1982, foi publicado um estudo sobre esse músico, escrito por Lange (Günther, Robert. Las culturas musicales de Latinoamérica en el siglo XIX. Tendencias y perspectivas. Germany: Gustav Bosse Verlag Regensburg, 1982). 
obras musicais brasileiras, informação sobre associações musicais, sobre todas as obras musicais editadas até aquele momento e o contato com músicos como Heitor Villa-Lobos, Lorenzo Fernández, "el señor Braga y sr. Burle-Max"111. Por essas solicitações, deduz-se que, naquele momento, Francisco Curt Lange não conhecia as proporções da produção musical brasileira e pedia ao musicólogo brasileiro uma tarefa difícil de ser plenamente executada por uma única pessoa. Em troca, Lange ofereceu de presente suas publicações, mas, depois que Mário de Andrade enviou-lhe seu livro Modinhas Imperiais (1930) como parte de suas solicitações, Lange desculpou-se por ter descumprido sua promessa, argumentando:

Aun no he podido publicar mis estudios, por ser muy extensos y no existir posibilidad alguna de hacerlos imprimir en ésta, porque aquí las imprentas roban descaradamente e imprimen mal. Sin embargo, he colaborado mucho en investigaciones sobre música alemana, luego he escrito infinidad de artículos, de los cuales le remitiré algunos dentro de pocos días ${ }^{112}$.

Embora nas primeiras cartas Francisco Curt Lange tenha contado que colaborava "constantemente con algunas Universidades alemanas en investigaciones sobre Schubert y Beethoven"113 e que trabalhava sobre nacionalismo musical russo $^{114}$, não são conhecidos escritos de sua autoria sobre esses temas ${ }^{115}$. Entre os escritos de Lange que chegaram à biblioteca de Mário de Andrade, estão o folheto Mecanização da música e a supersaturação musical (1935)116, o folheto Americanismo Musical (1934) ${ }^{117}$, o artigo "Fonografía pedagógica", publicado em duas partes (1934 y 1935) ${ }^{118}$, o livro La posición de Nietzsche frente a la guerra, el

${ }^{111}$ Carta de Francisco Curt Lange, Montevideo, 8 mar. 1933. IEB-USP: 3895.

112 Carta de Francisco Curt Lange, Montevideo, 8 mar. 1933. IEB-USP: 3895.

${ }^{113}$ Carta de Francisco Curt Lange, Montevideo, 20 nov.1932. IEB-USP: 3894.

${ }^{114}$ Carta de Francisco Curt Lange, Montevideo, 29 nov. 1933. IEB-USP: 3896.

115 São conhecidas duas resenhas, publicadas pelo mesmo Mário de Andrade, nas quais referiuse de maneira positiva a duas palestras de Francisco Curt Lange, acerca da influência romântica nas biografias de Beethoven, feitas no Conservatório de São Paulo, em 1934 (Andrade, Mário de. "Prof. Curt Lange." [1934] In: Paulo Castagna (ed.), Música e Jornalismo: Diário de S. Paulo, São Paulo: Edusp/Hucitec, 1993 e Ibid.).

116 Lange, Francisco Curt. "La mecanización de la musica y la supersaturación musical." Boletin de la Universidad Nacional de La Plata. no. 4 (1933). Em 1933, Lange ofereceu esse tema para fazer uma palestra em São Paulo (Carta de Francisco Curt Lange, Montevideo, 29 nov. 1933. IEB-USP: 3896).

117 Lange. Americanismo musical. Lange enviou dois exemplares mais, para que Mário de Andrade os distribuísse (Carta de Francisco Curt Lange, Montevideo, 15 jun. 1934. IEB-USP: 3902).

118 Lange, Francisco Curt. "Fonografía pedagógica." Anales de Instrución Primaria. v. 1, (1935). O exemplar tem correções tipográficas feitas à tinta pelo próprio autor (Carta de Francisco Curt Lange, Montevideo, 11 oct. 1935. IEB-USP: 3913). 
estado y la raza (1938) $)^{119}$, Impresiones andinas $(1938)^{120}$ e a compilação de partituras Latin-american Art Music for the Piano by Twelve Contemporary Composers $(1942)^{121}$. Nenhum dos exemplares tem notas marginais de seu dono, o que nem sempre indica que tenham sido guardados sem ler, pois, em muitos casos, livros sem notas foram catalogados por Mário de Andrade em seu «fichário analítico», o que indicaria que houve uma primeira leitura.

Parece que Mário de Andrade conheceu bastante bem o trabalho editorial de Lange à frente da publicação dos volumes do Boletín Latinoamericano de Música. Além de ter participado com artigos nos tomos I e VI, — "Os Congos" (1935) e "As danças dramáticas do Brasil" (1946) — Mário de Andrade viu nascer e acompanhou por intermédio da correspondência de Lange muitos detalhes que estiveram por trás de cada financiamento, edição e venda da publicação. O Boletín Latinoamericano de Música foi uma das obras editoriais de maior envergadura realizada até então sobre música latino-americana. Feito dentro dos parâmetros acadêmicos, procurou não apenas divulgar as notícias musicais do continente, mas também servir de órgão para a difusão das pesquisas mais recentes e das partituras dos compositores mais ativos.

Na década de 1910, houve uma iniciativa similar, com a publicação quinzenal do periódico Correo musical sud-americano na Argentina, que reuniu uma fração de músicos latino-americanos para escrever artigos e resenhas sobre música europeia e latino-americana ${ }^{122}$. Nesse periódico, houve uma seção chamada "Hacia el americanismo musical", em que o músico colombiano Santos Cifuentes publicou escritos acerca da vida musical de alguns países latino-americanos, como Argentina, Colômbia e Venezuela ${ }^{123}$. Apesar da semelhança de objetivos com o Boletín de

119 Lange, Francisco Curt. La posición de Nietzsche frente a la guerra, el estado y la raza. Santiago de Chile: Ediciones Ercilla, 1938. Carta de Francisco Curt Lange, Montevideo, 26 may. 1938. IEB-USP: 3927.

${ }^{120}$ Lange, Francisco Curt. Impresiones andinas. Montevideo: Editorial Nueva América, 1938.

121 Latin-american Art Music for the Piano by Twelve Contemporary Composers. New York: G. Schirmer, 1942. Em 1938, Lange mencionou esse trabalho a Mário de Andrade e pediu que lhe enviasse uma partitura para piano, "que no sea demasiado extensa ni dificil", para a incluir na publicação (Carta de Francisco Curt Lange, Montevideo, 25 ene. 1938. IEB-USP: 3924).

122 Sabe-se que sua frequência foi quinzenal, graças à menção feita por Fernando Callejo Ferrer à colaboração da pianista porto-riquenha Trina Padilla de Suárez no referido jornal (Callejo Ferrer. Música y músicos portorriqueños. p. 262).

123 Em 1938, Francisco Curt Lange reconheceu, no prólogo do tomo IV do Boletín Latinoamericano de Música, que a coluna publicada no Correo musical sud-americano sob o título "Americanismo musical", era pioneira do seu movimento. 
Lange, o Correo musical sud-americano foi uma publicação similar aos jornais da belle époque, nos quais se confundem artigos e resenhas musicais com notícias da sociedade e anúncios comerciais. Por sua parte, o Boletín Latinoamericano de Música tinha um recorte mais acadêmico e era dirigido a um público versado em música. Não foram encontrados indícios de que o Correo musical sud-americano tenha sido conhecido por Mário de Andrade, diferentemente do Boletín Latinoamericano de Música, cujos seis tomos chegaram à biblioteca do escritor.

Para ilustrar o tipo de apoio dado por Mário de Andrade aos propósitos editoriais de Francisco Curt Lange, vale a pena mencionar o seguinte episódio. Em maio de 1944, Mário de Andrade publicou um artigo na Folha da Manhã, no qual anunciou que o tomo VI do Boletín seria dedicado ao Brasil. Contou quem estava participando de sua organização, apresentou o plano temático que seria seguido e deu todo seu apoio a esse trabalho, chamando a atenção para a importância da empreitada. Também enfatizou que, se esse Boletim saísse com falhas, estas seriam causadas apenas pelo grau de desconhecimento que existia acerca de certos temas da música brasileira como, por exemplo, sobre a música do período colonial ${ }^{124}$.

Ao que parece, uns dias após ter terminado o artigo, e antes de ser publicado, Mário de Andrade enviou a versão preliminar a Luiz Heitor Corrêa de Azevedo, advertindo-o de que era um artigo "unicamente para agitar a notícia e entusiasmar os colaboradores daqui" ${ }^{25}$. Entretanto, sabe-se que Francisco Mignone, meses antes, havia contado a Mário de Andrade que a comissão brasileira encarregada do Boletín estava "desorientada" e que viajaria a São Paulo para convencê-lo a participar. Conforme conta Mignone, sigilosamente, o maior problema estava sendo causado pelas imposições de Heitor Villa-Lobos.

É curioso relacionar o pronunciamento de Mário de Andrade sobre a publicação depois de conhecer os problemas internos que o Boletín vinha enfrentando. Além disso, umas semanas depois, essas dificuldades foram resumidas por Lange em uma carta, nos seguintes termos:

124 Andrade. "Número especial." [1944] Música final. Mário de Andrade e sua coluna jornalística Mundo musical.

125 Carta de Mário de Andrade, SP, 19 mai. 1944. Arquivo IEB-USP: MA-C-CAR131. 
Aquí, las cosas van devagar, pero muy posiblemente hacia una gran crisis. VillaLobos ya habla abiertamente a ciertas personas y hasta a un amigo mío de que si el Boletín no sale como él quiere, tirará su título y lo hará salir editado por su famoso Conservatorio. «Si sale peor o ruim, não faz mal porque de todas maneiras é nosso» (textual). No trabajo con gusto en semejante ambiente y con la seguridad de tener en cualquier momento graves inconvenientes. Su artículo, cuando le fue llevado por Luiz-Heitor, causó desagrado porque él no quiere de manera alguna que figure mi nombre «Por qué mencionan a él? si somos nosotros que hacemos el Boletín!» En fin, veremos lo que salga de esto. No me gusta brigar, pero si Villa quiere, la tendrá! Y con él todo el Estado Mayor de incondicionales que sólo parecen ser sus amigos porque les da de comer. No he visto nunca en parte alguna una persona que sea más detestada que ese hombre ${ }^{126}$.

Em julho do mesmo ano, dois meses após o pronunciamento de Mário de Andrade na imprensa, Francisco Curt Lange agradeceu seu "espírito de solidariedade" em relação a Villa-Lobos ${ }^{127}$.

Diferentemente do apoio e da colaboração que Mário de Andrade concedeu ao Boletín Latinoamericano de Música, parece que o escritor brasileiro manteve-se distante e reservado em relação ao chamado "americanismo musical" de Lange. Por meio da correspondência estudada, tem-se a impressão de que o autor paulista não deu muita importância à propaganda que o musicólogo alemão fazia de seu movimento como ocorreu em outros países da América Latina, onde criou devotados seguidores $^{128}$. Em 1939, no jornal O Estado de São Paulo, Mário de Andrade chegou mesmo a expressar incredulidade, escrevendo, com seu estilo característico:

O professor Curt Lange, de origem alemã, radicando-se definitivamente no Uruguai, vem desde longo tempo realizando uma dedicadíssima empreitada de intercâmbio musical americano. Escritor e crítico musical de rara abundancia, para coroar seu sonho, o Sr. Curt Lange chamou de «Americanismo musical», palavras incontestavelmente muito lindas, mas que, objetivamente não parecem corresponder a nenhuma verdadeira realidade. É o próprio Prof. Curt Lange quem se encarregará de me fortificar nesta dúvida minha ${ }^{129}$.

Assim Mário de Andrade iniciou o artigo "Nacionalismo musical”, no qual criticou os comentários de Lange acerca da acolhida da música de Lorenzo Fernandez, pelo público bogotano, durante o Festival de Música Americana de 1938. Segundo o artigo, Lange afirmou que a música brasileira estava mais próxima do

${ }^{126}$ Carta de Francisco Curt Lange, RJ, 21 jun.1944. IEB-USP: 3939.

127 Carta de Francisco Curt Lange, RJ, 6 jul.1944. IEB-USP: 3940.

128 De acordo com a resenha "Prof. Curt Lange" sobre a conferência de 24 de novembro de 1934, escrita por Mário de Andrade, essa palestra versou sobre o "americanismo musical", mas ele não assistiu porque esteve presente na estréia da Companhia Lírica (Andrade. "Prof. Curt Lange." [1934] Música e Jornalismo: Diário de S. Paulo)

129 Andrade. "Nacionalismo musical." [1939] Música, doce música. Estudos da crítica e folclore, p. 293. 
gosto das pessoas sem preparo musical e que o entusiasmo que despertou tinha sido graças ao seu ritmo e colorido, enquanto obras de grande inteligência, como as de Guillermo Uribe Holguín - compositor colombiano — passaram indiferentes. Disse Mário de Andrade "há em tudo isto que escreveu [...] tanta confusão, tamanha mistura de verdade e de vaguezas, que nem sei por onde começar um arranjo novo" 130.

Entre os pontos mencionados, Mário de Andrade retomou a ideia de Lange de desprezar o "Batuque" do Lorenzo Fernández por não ser contemporâneo e sim estritamente regional, e mostrou a contradição que havia em se rechaçar o regional quando ele mesmo mantinha esse parâmetro como lema.

Conclui-se do que diz o crítico que quando uma peça é regional, «local», como ele diz, deixa por isso de ser contemporânea? Mas neste caso eu desejaria saber mais objetivamente o que é o americanismo musical por que tão nobremente se dedica o Prof. Curt Lange? ${ }^{131}$

Não foram encontradas as reações de Francisco Curt Lange às palavras do escritor paulistano, mas se vê na correspondência que, antes que Mário de Andrade fizesse seu pronunciamento na imprensa, houve um distanciamento de um ano entre os dois personagens e, 15 dias depois de publicado o artigo citado, Lange escreveulhe do México falando de suas últimas atividades. A carta seguinte que foi conservada é de dois anos depois, e não menciona o assunto.

Em geral, observa-se que a relação que talvez tenha existido entre Mário de Andrade e Francisco Curt Lange teve um caráter mais político que acadêmico. Diferentemente de suas cartas com colegas brasileiros, a correspondência de Mário de Andrade com o musicólogo alemão não aprofundaram assuntos musicais e, apesar de Lange ter mencionado o tema do americanismo musical, parece que Mário de Andrade não se interessou em discuti-lo por correspondência.

Para finalizar, há que se assinalar que, em 1934, Francisco Curt Lange quis relacionar Mário de Andrade com o chileno Carlos Lavín. Parece que o artigo "Os cocos", com o qual Mário de Andrade participou do primeiro volume do Boletín Latinoamericano de Música, foi entregue a Lavín, provavelmente como encomenda editorial. Lange o apresentou ao chileno dizendo:

${ }^{130}$ Ibid., p. 296.

131 Ibid. 
...ha estudiado mucho el problema de los negros y leerá con gran interés y la correspondiente comprensión, su trabajo. Lavin ha estudiado también algunos idiomas del centro de África y tiene interesantes estudios hechos. Haré lo posible por relacionar a Uds., - además Lavin remitirá una colaboración de carácter folklórico cuyo tema aun no conozco ${ }^{132}$.

Dois meses depois, em outra carta, Lange informou-lhe o endereço de Lavín em Barcelona e, embora as referências que deu sobre o autor chileno sejam estranhas pelo fato de Lavín não se ter caracterizado por trabalhar com música africana, mais estranho parece o fato de Mário de Andrade não tê-lo informado de que já havia mantido correspondência com o chileno e conhecia algumas de suas publicações.

Além do contato que tinha com Francisco Curt Lange e com o que ocorria à sua volta, Mário de Andrade também manteve alguma correspondência com pesquisadores hispano-americanos da Colômbia, México, Chile e, talvez, Argentina. Seu conhecimento dos trabalhos de seus colegas latino-americanos ficou gravado em seu «fichário analítico», onde, além de catalogar textos de seus correspondentes, incluiu textos sobre a música de Cuba e do Peru. Por intermédio dessas fichas, sabese que também conheceu os livros de Nicolas Slonimsky, South American Composers (1940) ${ }^{133}$, de Eleanor Hague Latin American Music, Past and Present (1934) $)^{134}$ e Musik, Tanz und Dichtung bei den Kreolen Amerikas (1913) ${ }^{135}$, de Albert Friedenthal, que serviram para lhe dar um panorama geral do que acontecia musicalmente em outros países da América hispânica.

\subsection{Da Colombia, Emirto de Lima}

Uma curta correspondência entre Mário de Andrade e o músico e pesquisador colombiano Emirto de Lima foi conservada ${ }^{136}$. Sabe-se que Lima nasceu na ilha de Curaçao e iniciou seus estudos musicais com seu pai. Ao que parece, ainda jovem, viajou à Europa para estudar no Liceu musical Almicare Zanella de Gênova e

\footnotetext{
132 Carta de Francisco Curt Lange, Montevideo, 28 abr. 1934. IEB-USP: 3901.

133 Slonimsky, Nicolas. South American Composers. New York: Musical America, 1940.

${ }^{134}$ Hague, Eleanor. Latin American Music, Past and Present. Santa Ana, Calif: Fine Arts Press, 1934.

135 Friedenthal, Albert. Musik, Tanz und Dichtung bei den Kreolen Amerikas. Berlin: Wilmersdorf, 1913.

136 Infelizmente, a vida e obra musicológica e musical de Emirto de Lima tem sido pouco estudada em virtude da escassa documentação que foi conservada sobre ele. Atualmente, conta-se com um único trabalho, realizado pela musicóloga Ellie Anne Duque, quem coletou algumas partituras e escreveu um pequeno estudo histórico (Duque, Ellie Anne. Emirto de Lima (1890-1972) antología: pasillos, danzas y canciones. Bogotá: Fundación de Música, 2001).
} 
na célebre Schola Cantorum, com Vicent D'Indy, em Paris ${ }^{137}$. Após essa formação, chegou a viver em Barranquilha - cidade portenha da costa do Caribe colombiano — no início da década de 1910. Segundo informação dada por ele, Emirto de Lima graduou-se como doutor em musicologia na Andhra Research University (Vizianagaram, Índia) ${ }^{138}$.

A vida de Emirto de Lima esteve dividida entre sua atividade musical e suas gestões à frente dos consulados da Libéria e de Honduras a partir de $1937^{139}$. Como músico, publicou e gravou algumas de suas composições, foi pianista e violinista, abriu uma escola de música, além de ter participado da radiofonia nascente entre 1929 e 1930. Também trabalhou como diretor de orquestra na rádio, fez pesquisas em torno da música tradicional e popular da costa atlântica e trabalhou como crítico musical, uma vez estabilizada a orquestra Filarmônica de Barranquilha em $1943^{140}$. Lima combinou essas atividades com um rico intercâmbio epistolar com pessoas e instituições de todo o mundo, do qual só são conhecidas as cartas enviadas a Mário de Andrade. Segundo o próprio compositor, manteve correspondência com a Academia Hispano-Americana de Artes y Ciencias (Cadiz), com o Instituto Histórico de Alagoas, com o Ateneo de Caracas, com o Ateneo Musical Mexicano, com a Asociación de Escritores y Artistas Americanos de Havana, com a International Society for Contemporary Music (Inglaterra), com a Société Internationale de Musicologie (Suíça), com a Sociedad Folklórica do México, com a Sociedad de

137 Duque duvida que Emirto de Lima tenha-se formado na Europa em razão de algumas incongruências nas datas. Não entanto, a musicóloga reconhece como indício de sua estadia na Itália as anotações em italiano em suas partituras, que dão mostras de seu domínio do idioma. Segundo esse argumento, também seria comprovada a sua estadia na França, já que músico colombro-curazenho escreveu a primeira carta a Mário de Andrade em francês.

${ }^{138}$ Lima, Emirto de. Folklore colombiano. Barranquilla: s.e., 1942, p. [vii]

139 De acordo com a correspondência enviada a Mário de Andrade, em 1941, Lima levava 4 anos trabalhando como cônsul de Liberia e de Honduras (Carta de Emirto de Lima, Barranquilla, 26 jul. 1941. IEB-USP: 4124). É provável que sua chegada a esses cargos diplomáticos tenha estado mediada por um possível vínculo à maçonaria, indicada por Duque e pelo cartão de apresentação enviado ao Mário de Andrade onde se pode ler uma lista de títulos como "Gran dignatario de la orden de la Corona de Carlo Magno, Gran cordón de la Orden «Universalis Mereti», [...], Gran cruz de la orden del León y de la Cruz Negra", etc. (Bilhete de Emirto de Lima, Barranquilla, 27 mar. 1941. IEB-USP: 4123).

140 Duque. Emirto de Lima (1890-1972) antología: pasillos, danzas y canciones. p. 9. 
Geografia do Rio de Janeiro, com a Associação Brasileira de Música, com a Sociedad de Cultura Musical do Rio Grande do Norte, etc. ${ }^{141}$.

Barranquilha, a cidade onde Emirto de Lima viveu, assemelha-se a São Paulo, cidade de Mário de Andrade, por se tratar de um centro urbano cujo crescimento deu-se de modo acelerado no final do século XIX, passando de uma província menor, durante o período colonial, a um dos centros urbanos colombianos mais importantes, no século XX. A importância de Barranquilha deve-se ao fato de ter possuído o principal porto marítimo e fluvial colombiano. A intensa atividade portuária de Barranquilha foi estimulada pelo desenvolvimento da navegação a vapor na segunda metade do século XIX, que uniu a costa atlântica com o centro do país por meio do rio Magdalena. Barranquilha foi a principal porta de entrada e saída do país, tanto de produtos comerciais quanto culturais até meados do século $\mathrm{XX}$, quando o desenvolvimento da aviação tirou-lhe o protagonismo. Durante a primeira metade do século XX, essa foi uma das cidades colombianas com maior crescimento graças, entre outros fatores, ao fato de receber ondas migratórias de sírio-libaneses, europeus e orientais. Ainda que esse trânsito desse-se em menores proporções que o de São Paulo, seu impacto foi similar para a configuração da cultura urbana.

Musicalmente, Barranquilha foi uma das primeiras cidades colombianas a receber a visita de uma jazz-band, por volta de 1921, e a receber as primeiras gravações musicais em discos de $78 \mathrm{rpm}$. Também contava com uma Academia de música, além da escola fundada por Emirto de Lima, e com uma orquestra sinfônica com um formato instrumental atípico, em comparação com a configuração orquestral moderna, pois agregava instrumentos como violões e bandolins ao lado dos violinos, celos e piano ${ }^{142}$.

Assim como ocorreu com Mário de Andrade em São Paulo, Emirto de Lima, em Barranquilha, foi testemunha do crescimento acelerado de um centro urbano que passou a consolidar uma cultura ligada às modas internacionais. É provável que essas mudanças rápidas tenham levado o compositor a valorizar a música dos camponeses

141 Provavelmente, Emirto de Lima também trocou correspondência, no Brasil, com Luiz Heitor Corrêa de Azevedo, quando este era secretario da Associação Brasileira de Música. Além disso, o músico carioca citou pesquisas de Lima em Dois pequenos estudos de folclore musical, ao se referir à Colômbia e, juntos, os pesquisadores compartilharam amizade com Francisco Curt Lange.

142 Ibid., p. 11. 
da região e a iniciar jornadas de trabalho de campo, procurando registrar e estudar sua música. Partícipe de uma visão de mundo romântica, Emirto de Lima reprovou a música popular urbana, compilou e estudou a música camponesa e compôs segundo os parâmetros nacionalistas impostos por Bogotá. Em que pese ter dado mostras de conhecer a tradição musical caribenha por meio de suas pesquisas, suas observações permaneceram em letra impressa, não alimentando sua produção musical.

Seu conceito romântico de música popular provavelmente exerceu influência sobre suas composições musicais, sempre inclinadas a uma linguagem musical romântica. Lima teve uma clara preferência por ritmos como o pasillo e o bambuco, que eram gêneros oitocentistas do interior do país e bandeiras do nacionalismo musical daquele tempo ${ }^{143}$. Sua predileção por esse repertório permitiulhe participar do fenômeno discográfico colombiano, com obras como seu bambuco, Piacito de Cielo, gravado pela discos Brunswick em Nova Iorque, em 1928, com interpretação de Pilar Arcos e Fortunio Bonanova ( $\int$ faixa 1) ${ }^{144}$.

Graças às cartas enviadas a Mário de Andrade, sabe-se que, em 1931, Emirto de Lima já tinha lido os trabalhos do escritor brasileiro, Ensaio sobre a música brasileira (1928), Modinhas imperiais (1931) e seu artigo "Originalidade do maxixe" (1931), pois a correspondência entre os dois autores iniciou-se como resultado de uns cumprimentos enviados por Emirto de Lima ${ }^{145}$. O intercâmbio bibliográfico parece que continuou e, em 1934, chegou a Barranquilha a recompilação de artigos Música, doce música (1933) ${ }^{146}$, de Mário de Andrade, conforme carta de agradecimento de Lima. Em 1941, este contou que havia lido também os artigos "Expressão musical dos Estados Unidos" (1940) e "A nau catarineta" (1941), e agradeceu de novo ao autor pelo envio ${ }^{147}$. O interesse e conhecimento de Emirto de Lima sobre a obra de Mário de Andrade e a música no

143 Ibid.

144 Dados da gravação em: Laird, Ross. Brunswick Records: New York sessions, 1927-1931. Westport, Conn.: Greenwood Press, 2001.

${ }^{145}$ Bilhete de Emirto de Lima, Barranquilla, 9 mar. 1931. IEB-USP: 4115 e Carta de Emirto de Lima, Barranquilla, 27 may. 1931. IEB-USP: 4116.

146 Bilhete de Emirto de Lima, Barranquilla, 27 dic. 1934. IEB-USP: 4119.

147 Carta de Emirto de Lima, Barranquilla, 26 jul. 1941. IEB-USP: 4124. Na Revista do Municipal, Mário de Andrade também publicou "Normas para bôa pronúncia da língua nacional no canto erudito" (1937) e "Atualidade do Chopin" (1942), provavelmente também lidos por Lima (Cartas de Emirto de Lima, Barranquilla, 4 nov. 1943. IEB-USP: 4127 y Barranquilla, 31 dic. 1943. IEB-USP: 4128). 
Brasil certamente refletiu-se nos escritos "Mário de Andrade", "Un gran músico: Luciano Gallet", "El arte musical en el Brasil" e "El folklore brasileño", que mencionou ter escritos e cujo paradeiro é incerto ${ }^{148}$.

De autoria de Emirto de Lima, repousam na biblioteca de Mário de Andrade o livro Folklore Colombiano (1942) e as partituras Impromptu N.3 e o pasillo Mayo. Trovador de venturas ${ }^{149}$. O exemplar do livro, embora não possua sublinhados ou notas marginais, está catalogado no «fichário analítico», junto a um artigo sobre o violão, do mesmo autor, publicado em 1938 na Revista Brasileira de Música ${ }^{150}$. Além disso, de acordo com a nota bibliográfica da entrada "Mapalé", do Dicionário musical brasileiro (1989) de Mário de Andrade ${ }^{151}$, sabe-se que o autor paulista leu outro artigo do Emirto de Lima, chamado "Várias manifestações folklóricas na costa colombiana do Atlântico" (1933), publicado pela Revista da Associação Brasileira de Música ${ }^{152}$.

Enquanto Mário de Andrade e Emirto de Lima trocavam correspondência, no centro da Colômbia deu-se um intrincado debate em torno do que era música nacional. Seus protagonistas não foram pesquisadores musicais, mas sim músicos, jornalistas e políticos, que escreveram acalorados artigos, baseados mais em seus interesses particulares do que em resultados de pesquisas ou reflexões musicais.

De acordo com o historiador Jaime Cortês,

A pesar de que el punto central del debate era la música nacional, el fondo del conflicto lo impelía la preocupación por legitimar dos tipos de prácticas musicales que comenzaban a diferenciarse: una de claro sesgo académico y otra de índole popular, ésta última entendida como fenómeno que podía ser masivo y que se fundamentaba en el mercado discográfico, en los espectáculos, la radiodifusión y en general la industria del entretenimiento ${ }^{153}$.

\footnotetext{
148 Lima. Folklore colombiano. p. 217.
}

149 Em 1941 Emirto de Lima enviou um livro de partituras de sua autoria a São Paulo, mas errou o endereço de Mário de Andrade e não se sabe se as partituras mencionadas correspondem com as enviadas (Bilhete de Emirto de Lima, Barranquilla, 27 mar.1941. IEB-USP: 4123). no. 1 (1938).

${ }^{150}$ Lima, Emirto de. "A guitarra, instrumento romanceiro." Revista Brasileira de Música. v. 5,

${ }^{151}$ Andrade. Dicionário Musical Brasileiro.

152 Lima, Emirto de. "Várias manifestações folklóricas na costa colombiana do Atlântico." Revista da Associação Brasileira de Música. v. 2, no. 5 (1933).

153 Cortés Polanía, Jaime. La música nacional y popular colombiana en la colección Mundo al día (1924-1938). Bogotá: Universidad Nacional de Colombia, 2004. 
As cabeças mais visíveis desse debate foram as dos músicos Emilio Murillo e Guillermo Uribe Holguín, duas figuras antagônicas sobre as quais se voltará a falar, no segundo capítulo, para ilustrar a dicotomia popular/erudito presente no conceito de música popular. Embora Emirto de Lima não tenha sido um dos atores principais em dito debate, foi uma figura interessante da musicologia colombiana, de uma parte, graças a seu pensamento nacionalista e ligação com a visão de mundo romântica, e por outra, graças a seus estudos da música tradicional colombiana e a sua leitura de trabalhos de colegas como Mário de Andrade.

\subsection{Do México, Vicente T. Mendoza}

Assim como o Brasil, o México é um país latino-americano interessante para estudar a construção do conceito de música popular, dada a grande relevância que ali tiveram a precoce indústria fonográfica e o movimento românticonacionalista nas artes. Como se verá nos seguintes capítulos, considera-se que o nacionalismo e, pouco a pouco, a indústria fonográfica, entenderam por música popular dois tipos de música cada vez mais díspares, e isso colaborou para lhe conferir seu atual caráter polissêmico.

Embora Mário de Andrade tenha mostrado grande interesse pela música do México, não foi essa problemática a que despertou sua curiosidade. De acordo com seu «fichário analítico», parece que os olhos e ouvidos do musicólogo brasileiro estiveram mais atentos à música indígena e à atividade de músicos mexicanos contemporâneos. Talvez, a maioria das notícias sobre a música de México tenha chegado à Rua Lopes Chaves em São Paulo por meio de publicações mexicanas e de revistas como o Boletín Latinoamericano de Música, Musical Quartely e Gaceta Musical. Em comparação com as notas deixadas por Mário de Andrade sobre a música de outros países hispano-americanos, a música mexicana reúne um número maior. Mas, contrariamente, em seus escritos publicados são poucas as referências a ela.

Em seu «fichário analítico», está catalogado o trabalho do Gabriel Saldivar, Historia de la música en México, época precortesiana y colonial (1934) ${ }^{154}$,

154 Saldívar, Gabriel. Historia de la música en México: épocas precortesiana y colonial. México: Editorial Cvltvra, 1934. 
conservado em sua biblioteca sem anotações marginais. $\mathrm{O}$ colecionador e pesquisador Gabriel Saldivar (1909-1980) é considerado fundador da historiografia musical mexicana interessada pela música do período colonial, graças a seu livro que Mário de Andrade conheceu, ao arquivo de documentos musicais que recolheu ao longo de sua vida e à elaboração da Bibliografia mexicana de musicologia y musicografia (1992), publicada postumamente ${ }^{155}$. Em seu livro sobre a música colonial, Saldivar contribuiu com uma vasta documentação musical, desconhecida até então, e com rigor delineou aspectos sociais e musicais do passado mexicano. Não se conhecem as impressões que Mário de Andrade teve sobre esse trabalho, uma vez que não foram encontradas menções a ele em seus escritos.

O que se encontra na biblioteca que pertenceu a Mário de Andrade é o livro Folklore y la música mexicana (1928), de Rubén M. Campos (1871-1945), com notas que mostram uma leitura detalhada de seu dono. Graças a elas, intui-se que Mário de Andrade aproveitou esse livro para reunir informações sobre instrumentos musicais indígenas mexicanos, alguns gêneros musicais, costumes musicais natalinos — que Mário de Andrade anotou como "pastoril" - e uso de recursos musicais como a variação. Além disso, Mário de Andrade sublinhou algumas similitudes entre a música mexicana e a brasileira, pois, nas partituras do anexo, fez notas como a observação "Oh vizinha minha sinhô (harmonisação por Luciano Gallet)", nos primeiros compassos da partitura de Jarabe del bajio, e o adjetivo "caipira" na partitura de Guajito. O livro de Rubén M. Campos não foi tão celebrado pela historiografia mexicana quanto o de seu colega Saldivar, talvez em virtude do caráter literário da obra. Além disso, também pode ter influído no seu baixo prestigio o fato de que Campos era mais reconhecido entre seus contemporâneos por seu desempenho como literato modernista. Seu interesse pela história musical foi tardio e se desenvolveu em paralelo à escrita de outros trabalhos como El folklore literario de México (1929) e El folklore musical de las ciudades (1930).

$\mathrm{O}$ autor mexicano mais bem representado na biblioteca de Mário de Andrade é Vicente T. Mendoza (1894-1964), considerado fundador dos estudos de folclore em seu país. Aluno de Rubén M. Campos no Conservatório Nacional de

155 Saldívar, Gabriel. Bibliografía mexicana de musicología y musicografía. México: INBA CENIDIM, 1992. 
Música e discípulo do compositor Julian Carrillo, combinou seus estudos de música com estudos de tipografia e trabalhos ocasionais nos cinemas Politeama e Goya, como pianista ${ }^{156}$. Por pertencer a uma família de província, sua chegada à capital o obrigou a passar por vários trabalhos antes de se dedicar à pesquisa musical e, na opinião de Robert Stevenson, sua origem humilde conferiu uma perspectiva particular a suas pesquisas ${ }^{157}$.

Em 1938, durante os meses em que renunciou ao seu cargo no Departamento de Cultura, Mário de Andrade recebeu uma carta enviada do México por Vicente T. Mendoza que, naquele momento, já tinha uma certa trajetória como pesquisador. Fazia dois anos que trabalhava no Instituto de Investigaciones Estéticas da Universidade do México e já havia conhecido Ralph Steele Boggs — também amigo de Mário de Andrade -, com quem depois estudaria, e cuja definição clássica de folclore adotaria ${ }^{158}$. Em 1938, Mendoza também participou da fundação da Sociedad Folclórica de México, da qual foi secretário e presidente e, nesse ano, iniciou sua participação no Boletín Latinoamericano de Música, a convite de Francisco Curt Lange. Foi nesse mesmo ano que se dirigiu a Mário de Andrade e lhe enviou seu livro Instrumental precortesiano. Instrumentos de percusión (1933), uma de suas primeiras publicações, em companhia de Daniel Castañeda ${ }^{159}$.

Muy señor mío[:] A su paso por esta capital del Sr. Felipe L. Barbour tuvo a bien hablarme de usted y de la eminente labor que realiza con respecto a investigaciones sobre la música brasileira, asunto para mí del más alto interés y sabiendo por el mismo caballero que a usted podrían interesarle igualmente los trabajo y estudios que se realizan en México, en este mismo sentido, y con el fin de establecer un intercambio provechoso, así como para estar en contacto con usted, le envío por

156 Meierovich, Clara. Vicente T. Mendoza. Artista y primer folclorólogo musical. Ciudad de México: Universidad Nacional Autónoma de México, 1995.

157 Stevenson, Robert. "Vicente T. Mendoza." Journal of the International Folk Music Council. v. 18, (1966).

${ }^{158}$ Ralph Steele Boggs foi bibliógrafo e pesquisador da seção de folclore do Handbook of Latin American Studies entre 1936 e 1945. Manteve contato com estudiosos latino-americanos, como Mário de Andrade, a quem dirigiu-se para pedir material sobre o folclore brasileiro em 1938. Mário de Andrade conhecia seu escrito "La recolección de la música folclórica en el Nuevo Mundo" publicado no Boletín Latinoamericano de Música (Tomo V).

Em 1940, Luiz Heitor Corrêa de Azevedo contou a Mário de Andrade, por carta, que Ralph Steele Boggs viajara ao Rio de Janeiro e que estava "danado" com Mário por este ter ido embora um dia antes da sua chegada. Corrêa de Azevedo descreveu o folclorista norte-americano como "um sujeitinho meio enguiçado, mas muito trabalhador" (Carta de Luiz Heitor Corrêa de Azevedo. RJ, 24 nov. 1940. IEB-USP: 915; 26 jul. 1941. IEB-USP: 4124).

159 Castañeda, Daniel e Mendoza, Vicente T. Instrumental precortesiano. Instrumentos de percusion México: Imprenta del Museo Nacional de Arqueología, Historia y Etnografía, 1933. 
conducto de la Embajada de su país en México, un ejemplar de la obra "Instrumental precortesiano" hecha en colaboración con un amigo mío ${ }^{160}$.

Essa é a única carta conservada entre os dois autores. O livro mencionado não se encontra na biblioteca de Mário de Andrade, mas está corretamente fichado nas papeletas correspondentes ao México em seu «fichário analítico». Em sua biblioteca, foi conservado um exemplar de Romance español y el corrido mexicano: estudio comparativo (1939), livro que Mendoza publicou no ano seguinte, após ter iniciado contato com o autor paulistano, permitindo supor um maior intercâmbio ${ }^{161}$.

Outro dos livros sobre música no México, publicado durante a vida de Mário de Andrade, foi Nociones de historia de la música mejicana (1933), do médico Miguel Galindo Velasco ${ }^{162}$. Embora não existam rastros desse livro entre os papéis de Mário de Andrade, sua menção é importante porque a visão de seu autor foi relevante para o estudo do conceito de música popular, como se verá nos capítulos seguintes. Ao que parece, é pequeno o reconhecimento que esse livro tem tido por parte da historiografia musical mexicana em face da quantidade de informação que reuniu. É possível que este texto tenha sido renegado em razão da visão nacionalista de seus colegas, que não gostaram do espaço generoso que Galindo concedeu à história política mexicana e à música espanhola.

Chama a atenção o fato de que alguns argumentos de Miguel Galindo tenham sido similares aos que Mário de Andrade construía ao mesmo tempo na América do Sul. Não obstante, Galindo diferencia-se de Mário de Andrade em vários aspectos, além de sua formação. Em primeiro lugar, o interesse de Galindo pela história musical foi ocasional e se limitou a esse livro, escrito ao final de sua vida, ao lado de outros trabalhos de recorte histórico sobre literatura, pedagogia e medicina. Galindo não teve formação musical exceto, talvez, algumas noções básicas que o obrigaram a contar com a assistência do compositor e organista Alfredo Carrasco (1875-1945) para o estudo dos instrumentos indígenas e a transcrição da música que acompanhou sua obra. Tampouco teve o reconhecimento intelectual de Mário de Andrade e, com o tempo, seu trabalho foi esquecido pela musicologia mexicana. Os

${ }^{160}$ Carta de Vicente T. Mendoza, México D.C., 4 may. 1938. IEB-USP: 4685.

161 Mendoza, Vicente T. El romance español y el corrido mexicano; estudio comparativo. México: Ediciones de la Universidad nacional autónoma, 1939. 1933.

162 Galindo, Miguel. Nociones de la historia de la música mejicana. Colima: Tip de El Dragón, 
dois autores foram similares em sua proximidade com a religião católica: o autor mexicano foi influenciado pela figura de um tio bispo e por sua curta passagem pelo seminário, ao passo que o autor paulista manteve devoção católica própria, influenciada por sua família. Como não há indícios de que esses dois autores tivessem contato, nem de que conhecessem o trabalho um do outro, deduz-se que os contextos socioculturais em que viveram, tenham feito com que ambos prestassem atenção a aspectos similares da música popular pela qual se interessaram.

\section{$\underline{3.4 \text { De Cuba, Eduardo Sánchez de Fuentes e Fernando Ortíz }}$}

Ao contrário do caso mexicano, a música cubana foi mencionada mais de uma vez por Mário de Andrade em seus escritos publicados. Além disso, suas fichas, sua coleção de discos de $78 \mathrm{rpm}$ e alguns tomos de sua biblioteca dão a perceber que a música da ilha despertou particular interesse no escritor paulistano. Embora não tenha chegado à casa da rua Lopes Chaves nenhuma carta proveniente de Cuba, chegaram algumas das principais publicações que os intelectuais cubanos estavam produzindo.

Cuba era herdeira de uma rica atividade musical oitocentista, de acordo com as modas europeias, que continuou durante todo o século XIX, até a independência espanhola em 1892. Depois, vieram mudanças interessantes sob a forte intervenção política estadunidense. A ligação com os Estados Unidos criou um clima de progresso e crescimento econômico, cuja fragilidade foi visível com a conjuntura da Primeira Guerra Mundial, despertando um clima político e intelectual acalorado, tanto a favor quanto contra as medidas intervencionistas.

Durante o período colonial, Cuba havia sido uma das metrópoles do império espanhol e uma porta de entrada para suas colônias americanas. Desde então, passaram por ela grandes somas de capital, o que atraiu músicos famosos, companhias de ópera, orquestras e compositores, europeus e norte-americanos, sobretudo no século XIX, quando se tornou rentável fazer turnês de concertos pela América Latina. Esses ares cosmopolitas herdados do século XIX e a posterior presença estadunidense, que converteu a ilha em balneário desse país, permitiram que sua música entrasse desde cedo na indústria discográfica. 
Como consequência, houve uma importante difusão da música cubana fora de seus limites nacionais e, "do outro lado do disco", entrou na ilha uma grande quantidade de música de outros países. De modo geral, a chegada da indústria discográfica aos países latino-americanos, ao lado da consolidação das culturas urbanas e da indústria de entretenimento, fez com que a atividade musical local sofresse mudanças notórias, de tal modo que aqueles que escreviam sobre música fossem levados a tomar certas atitudes ante as exigências da nova realidade.

No século XIX, foram escritos dois textos fundadores da historiografia musical cubana, elaborados por dois músicos reconhecidos, La Habana artística $(1891)^{163}$ e Las artes en Santiago de Cuba (1893) ${ }^{164}$ e, por outro lado, iniciou-se a crítica musical especializada, com Guillermo Tomás, outro músico importante. Esses antecedentes serviram de base para que, em princípios do século XX, houvesse um grupo de músicos e intelectuais que discutisse e escrevesse sobre música com um caráter que procurava ser científico.

Os cubanos contemporâneos a Mário de Andrade também trataram de responder às perguntas sobre identidade nacional e musical que seu tempo impôs. Assim como no resto da América Latina, seus trabalhos estiveram motivados pelo nacionalismo musical. Entretanto, as respostas que deram foram particulares e se viram refletidas na criação de dois grupos com opiniões opostas. O primeiro era encabeçado pelo famoso compositor e crítico musical Eduardo Sánchez de Fuentes (1874-1944), que tentou colocar o elemento indígena como diferenciador. O segundo grupo foi encabeçado por Fernando Ortíz (1881-1969), considerado fundador do "afro-cubanismo", que advogou pelo elemento negro. A essa corrente também pertenceram Gaspar Agüero (1873-1951) e Alejo Carpentier (1904-1980), entre outros músicos e escritores.

Tanto Eduardo Sanchez de Fuentes quanto, posteriormente, Fernando Ortíz, gozaram de reconhecimento no meio intelectual cubano e internacional. Ambos pertenceram à classe alta cubana, formaram-se em direito — Sanchez de Fuentes em

163 Ramírez, Serafín. La Habana artística. Apúntes históricos. Habana: Imp. del E.M. de la Capitanía General, 1891.

164 Fuentes Matons, Laureano. Las artes en Santiago de Cuba. Santiago de Cuba: Ravelo, 1893. 
Havana e Ortíz em Barcelona —, mantiveram contato com a elite política e ocuparam cargos administrativos, viajaram ao exterior e tiveram acesso a meios de difusão internacionais ${ }^{165}$.

A carreira de Sánchez de Fuentes é interessante porque, além de seu trabalho como crítico musical — reconhecido por ter incorporado a análise musical pela primeira vez —, ele é considerado fundador das pesquisas sobre as raízes culturais da música cubana e defensor da não imitação de padrões estrangeiros. Parece que seus livros tiveram uma boa distribuição porque, além de encontrar seus exemplares na biblioteca de Mário de Andrade, também foi citado por outros colegas latino-americanos, como o mexicano Rubén M. Campos ${ }^{166}$. Em geral, Sanchez de Fuentes argumentava que a música cubana vinha da Europa e tinha evoluído até se converter em música folclórica, com um elemento indígena notável. De acordo com a musicóloga cubana Yarelis Dominguez, sua obra tem "una marcada indeterminación terminológica en cuanto a la denominación de «folclórico», «tradicional»y "popular»"167. Essa "indeterminação" foi comum a outros autores latino-americanos e, possivelmente, deveu-se ao fato de as primeiras décadas do século XX terem representado um momento de trânsito das práticas musicais, como se verá nos capítulos seguintes.

Eduardo Sanchez de Fuentes teve ampla aceitação e reconhecimento como compositor. De modo geral, as biografias concentram-se em seus trabalhos musicais como compositor e gestor cultural. Menciona-se a composição de numerosas óperas, operetas e zarzuelas, premiadas em Cuba e apresentadas na Europa. Entre suas inúmeras canções, a que lhe valeu maior reconhecimento foi a habanera "Tú" ( $\delta$ faixa 2), cuja partitura publicou-se em 1894 e foi gravada pela Victor em 1909. Assim como se deu com o colombiano Emirto de Lima, a música de Sánchez de Fuentes foi coerente com seus argumentos escritos. Mas, no caso de Fuentes,

165 Giro, Radamés "Ortíz, Fernando." Diccionario enciclopédico de la música cubana, La Habana: 2007 e Giro, Radamés "Sanchez de Fuentes, Eduardo." Diccionario enciclopédico de la música cubana, La Habana: 2007.

166 Campos, Rubén. El folklore y la música mexicana. México: Secretaria de Educación pública Talleres gráficos de la Nación, 1928, p. 68.

167 Dominguez Benejam, Yarelis. Caminos de la musicología cubana. La Habana: Editorial Letras Cubanas, 2000, pp. 30-31. 
distingue-se a estética da ópera e se põe em concordância sua obra musical com seus postulados sobre a origem hispânica da música cubana ${ }^{168}$.

De sua parte, Fernando Ortíz iniciou-se no mundo das letras escrevendo sobre criminalística, com um claro enfoque naturalista e interessado em relacionar os protótipos raciais com comportamentos criminosos. Ao que parece, esses primeiros trabalhos o levaram a se interessar pela santería, pelos ritos e costumes da população negra cubana e, pouco depois, por sua música. Considera-se que seu primeiro trabalho sobre música folclórica foi o livro La Clave xilofonica de la música cubana. Ensayo etnográfico (1935), no qual começou a forjar o conceito de "transculturação", que usará mais tarde em sua chamada trilogia sobre o afrocubanismo, livros publicados na década de 1950: La africanía de la música folklórica de Cuba (1950) ${ }^{169}$, Los bailes y el teatro de los negros en el folklore de Cuba (1951) $)^{170}$ e Los instrumentos de la música afrocubana (1952) ${ }^{171}$, em cinco tomos. Como não teve formação musical, Fernando Ortíz foi assessorado pelo músico Gaspar Agüero, que havia estudado no Conservatório Nacional Hubert de Blanc - onde também estudou Eduardo Sanchez de Fuentes. Agüero ajudou Ortíz a fazer as transcrições e análises musicais usadas em toda sua obra, embora seu ofício principal fosse como organista, diretor de coral e professor na Escola Normal de Havana.

A historiografia cubana considera que o trabalho de Fernando Ortíz tenha sido responsável pela destruição dos postulados de Eduardo Sánchez de Fuentes porque, fazendo uso, pela primeira vez, de técnicas de trabalho de campo, passou a caracterizar a música cubana com base no elemento africano. Além disso, considerase que, a partir de seu trabalho como pesquisador, a musicologia cubana passou a ser científica por usar os métodos da etnologia, embora critiquem a ambiguidade com que manejou os conceitos de cultura e etnia. Sob influência da corrente afro-cubana,

168 Giro. "Sanchez de Fuentes, Eduardo." Diccionario enciclopédico de la música cubana.

169 Ortiz, Fernando. La africanía de la música folkórica de Cuba. [1950] Havana: Letras Cubanas, 1993.

170 Ortiz, Fernando. Los bailes y el teatro de los negros en el folklore de Cuba. [1951] Madrid: Editorial Música Mundana Maqueda, 1998.

171 Ortiz, Fernando. Los instrumentos de la música afrocubana. [1952] Madrid: Editorial Música Mundana Maqueda, 1996. 
surgiram outros trabalhos, como o de Emilio Grenet, Música popular cubana (1939), e a crítica e história da música escritas por Alejo Carpentier, um pouco depois ${ }^{172}$.

Ao que parece, uma parte da polêmica nacionalista musical que se estava desenrolando em Cuba chegou aos ouvidos de Mário de Andrade. Em sua biblioteca, havia exemplares de algumas das obras de Eduardo Sánchez de Fuentes, Fernando Ortíz e Emilio Grenet, assim como alguns artigos de crítica musical de Alejo Carpentier. O musicólogo brasileiro conheceu poucos trabalhos de Fernando Ortíz em comparação com o que seria a produção posterior do pesquisador. Leu com grande interesse seu livro Hampa afro-cubana. Los negros-brujos (apuntes para un estudio de etnología criminal), publicado em 1906 e reeditado em 1917. Ali, o musicólogo brasileiro deixou pistas de se haver interessado sobretudo por dados sobre religião e ritos afro-cubanos. Também conheceu o livro La Clave xilofonica de la música cubana. Ensayo etnográfico (1935) que, embora não possua notas de leitura, está catalogado em seu «fichário analítico». Além disso, nos apontamentos que deixou para seu Dicionário musical brasileiro ${ }^{173}$, Mário de Andrade citou os artigos de Fernando Ortíz publicados na revista Archivos del folklore cubano, da qual Ortíz era diretor, "Juegos infantiles cubanos" (1928) e "Los negros curros III, sus carácteres: el lenguaje"174.

Em contrapartida, Mário de Andrade conheceu melhor o trabalho sobre música de Eduardo Sánchez de Fuentes. O exemplar do livro El folk-lor en la música cubana (1923), distribuído pela Livraria Universal em São Paulo, tem diversas notas sobre as descrições de elementos musicais que o autor considerava característicos da ilha. Com a abreviatura "dicc.” Mário de Andrade fez chamadas nas margens para o vocabulário que denominava gêneros musicais (contradança, dança, danzón, tiranas, habanera, sapateado, ponto cubano, criolla, bolero, son), instrumentos musicais

172 Na biblioteca de Mário de Andrade, encontra-se um exemplar do livro de Emilio Grenet, Popular Cuban Music (1939), com prólogo de Eduardo Sánchez de Fuentes. O exemplar não possui notas à margem, mas pôs ao alcance de Mário de Andrade 74 partituras para piano e voz de música cubana, entre as quais há versões de música gravada, como a habanera "Tu", de Sánchez de Fuentes, o son "Negro bembón" e os sons "Héchale salsita" e "Son de la loma", entre outros êxitos da música popular cubana (Grenet, Emilio. Popular Cuban Music. 80 Revised and Corrected Composition, together with an Essay on the Evolution of Music in Cuba. Havana: Carasa, 1939).

173 Essa bibliografia é composta por 837 livros, que foram anotados por Mário de Andrade em ordem de leitura, com o propósito de alimentar seu dicionário musical (Andrade, Mário de. "Um projeto de Mário de Andrade e Na Pancada do Ganzá: Prefácio." Arte em Revista. v. 2, no. 3 (1980)).

${ }^{174}$ Andrade. Dicionário Musical Brasileiro. 
(tiple, bandurria ou três, bongô, maracas, bandola, chave), instrumentistas (guaracheros, rasugueadores, maraqueros) e elementos musicais (pontilhado, cinquillo e baixo antecipado), talvez com o propósito de inclúi-los em seu dicionário musical. Nas páginas 80 e 81, onde Sánchez de Fuentes vinha mostrando que a figura rítmica do bolero era uma variação da habanera, Mário de Andrade ressaltou a figura rítmica com um círculo em lápis preto e escreveu a palavra "maxixe" ao seu lado. Possivelmente, essa leitura sugeriu-lhe a ideia de que o maxixe descendia da música afro-cubana, ideia exposta em seu artigo "Cuba, outra vez" (1932):

É o caso, por exemplo, do tango e do maxixe, ambos provenientes, ou melhor, estimulados pela música afrocubana. Ambos surgem e se desenvolvem naqueles tempos em que a Habanera dominava as sociedades iberoamericanas ${ }^{175}$.

Nesse artigo, Mário de Andrade usou a palavra "afrocubana", ligada, segundo a historiografia cubana, à postura de Fernando Ortíz. Consequentemente, é provável que o conhecimento do autor paulista acerca das pesquisas de Fernando Ortíz não se limitasse aos textos mencionados.

Por outro lado, o livro do Sánchez de Fuentes, Folklorismo. Artículos, notas y críticas musicales (1928) - recopilação de escritos de crítica e pesquisa também foi lido por Mário de Andrade e parece que este achou interessantes todas as menções à música indígena e à existência de escalas pentatônicas, tema que o interessava, como se viu em sua leitura do trabalho de Luiz Heitor Corrêa de Azevedo.

\subsection{Do Chile, Carlos Lavín e Domingo Santa Cruz}

De acordo com o «fichário analítico», Mário de Andrade conheceu algo da pesquisa musical chilena por meio dos livros sobre a América Latina de Nicolas Slonimsky e do alemão Albert Friedenthal. Também folheou o folheto El camino de la música chilena. La interesante labor del compositor Carlos Lavín (s.d.), do escritor chileno Sady Zañartu176, além do artigo de Carlos Lavín, "Musique des Araucanes" (1925) 177 e de outros que foram catalogados simplesmente como

\footnotetext{
175 Andrade, Mário de. "Cuba, outra vez." [1932] In: Telé Ancona Lopez (ed.), Taxi e Crônicas no Diário Nacional, São Paulo: Duas Cidades. Secretaria da Cultura, Ciência e Tecnologia, 1976.

176 Zañartu, Sady. El camino de la música chilena: La interesante labor del compositor Carlos Lavin. s.1.: s.n., s.d.

${ }^{177}$ Lavín, Carlos. "La musique des Araucans." La Revue Musicale. no. 5 (1925).
} 
"Artigos de música", entre os quais estava "La procession sur les flots" (1928), também de Carlos Lavín ${ }^{178}$.

O caso chileno é interessante para a pesquisa musical latino-americana porque, na época em que Mário de Andrade viveu, este país dava mostras de ter uma geração de músicos interessados na pesquisa, bem como em institucionalizar o saber musical. Por exemplo, em 1924, Domingo Santa Cruz, advogado de formação e compositor, fundou a Sociedad Bach, que começou como uma associação de jovens universitários amantes do canto coral e depois se converteu no grupo que lutou pela institucionalização da atividade musical em seu país. À sombra da Sociedad Bach, nasceu um quarteto, uma orquestra, um conservatório e uma revista musical chamada Marsyas que, posteriormente, converteu-se em Aulos, depois na Revista de Arte e, em 1945, na atual Revista musical chilena. A essa sociedade pertenceram figuras como os compositores nacionalistas Pedro Humberto Allende e Jorge Urrutia Blondel.

Entre as cartas escritas a Mário de Andrade há uma de Domingo Santa Cruz, de quem só foram conservados um cartão de apresentação, sem data, com seu endereço em Santiago do Chile, escrito à mão ${ }^{179}$, e uma carta de 1942, na qual agradece a Mário de Andrade o envio de seus livros sobre música à biblioteca da Universidade do Chile ${ }^{180}$. Também estão conservadas duas cartas do compositor e pesquisador Carlos Lavín, uma figura com um perfil interessante por seus estudos sobre música indígena e sua formação ao lado de duas figuras europeias importantes da antropologia e da musicologia daquele momento.

A primeira carta de Carlos Lavín data de 1929. Foi escrita em francês e enviada de Paris ${ }^{181}$. Parece que Lavín interessou-se em entrar em contato com Mário de Andrade depois de ter lido seu Ensaio sobre a música brasileira (1928), que havia chegado à revista Gazeta Musical, da qual ele era colaborador. Nessa carta, Lavín (1928).

178 Lavín, Carlos. "La procession sur les flots." Revue de l'Amerique Latine. v. 16, no. 79

179 O fato de que o cartão tenha a letra manuscrita de Domingo Santa Cruz faz pensar em um eventual encontro entre os dois personagens no Brasil, posto que o oficio de advogado e funcionário do Ministério das Relações Exteriores chileno de Domingo Santa Cruz o levava a viajar para fora do Chile com frequência.

${ }^{180}$ Carta de Domingo Santa Cruz, Santiago, 10 sep. 1942. IEB-USP: MA-C-CP6323.

${ }^{181}$ Carta de Carlos Lavín, París, 2 août 1929. IEB-USP: 3950. 
conta que a revista teve de fechar e, por isso, ficou inédita a nota que ele escrevera sobre o livro. Também pediu ajuda a Mário de Andrade para completar suas informações sobre instrumentos de origem africana e estudos de música indígena no Brasil. Por último, anunciou o envio de artigos de sua autoria e lhe pediu o favor de remeter o catálogo da editora francesa Max Eschin a seus amigos Campassi e Camin, em São Paulo, para que pudessem pedir suas obras musicais a Paris ${ }^{182}$.

Entre os livros de Mário de Andrade foi encontrado um número da revista Gazeta Musical, mencionada por Lavín. Essa revista foi uma publicação feita em Paris por um grupo de intelectuais e músicos latino-americanos, entre os quais estava Manuel M. Ponce — diretor - , Alejo Carpentier e Adolfo Salazar. Ali, Carlos Lavín esteve encarregado da seção "La música en América", que resumia as atividades musicais de diferentes países latino-americanos, e da seção "Discos y rollos", além de colaborar com escritos sobre temas de folclore. Da Gazeta Musical, saíram somente nove números, entre 1928 e 1929, e sua importância deve-se ao fato de ter sido um órgão de difusão da música hispano-americana na Europa.

Carlos Lavín formou-se como músico em Santiago do Chile e se interessou, desde jovem, em estudar a música dos indígenas mapuches (grupo que vive ao sul da Argentina e do Chile). Paralelamente ao seu trabalho como compositor, iniciou um estudo bibliográfico e documental sobre a música daqueles indígenas. As amostras musicais em que trabalhou foram recolhidas por meio de terceiros, como o conhecido líder político indígena Manuel Aburto Panguilef e o missionário capuchinho Felix Jose de Augusta, que havia convivido com os mapuches.

Em 1922 Carlos Lavín viajou para a Europa, onde foi aluno do curso de etnografia de Marcel Mauss, na Sorbonne e, posteriormente, de Erich von Hornbostel, na Universidade do Berlim. Além da influência que essas duas figuras tiveram em sua produção investigativa, sabe-se que graças a Hornbostel, Lavín conheceu a coleção de música mapuche gravada em princípios do século $\mathrm{XX}$ e conservada no Arquivo Fonográfico do Laboratório de Psicologia da Universidade do Berlim, onde seu professor trabalhava.

182 João Compassi e Pedro Ângelo Camin, músicos donos de uma casa de edição musical em São Paulo, e o último, editor da Revista Ariel entre 1924 e 1929. 
A segunda e última carta de Carlos Lavín é de 1930 e está escrita em espanhol. Nela, o músico chileno responde a uma carta de Mário de Andrade manifestando que estava de acordo com a necessidade de integrar os estudiosos do folclore americano:

Me habla usted primordialmente sobre la necesidad de que los que nos ocupamos de folklore, en América, dejemos de estar aislados, y como soy de la misma opinión de Ud, me encuentro encantado de corresponder con Ud., esperando que esta correspondencia sea seguida ${ }^{183}$.

Essa é uma carta extensa, em que Lavín agradece o envio do Compêndio da história da música (1929), texto que leu e resenhou na revista Música de Barcelona $^{184}$. Também agradeceu a ajuda fornecida por Mário de Andrade com a informação sobre instrumentos de origem africana e os escritos sobre música indígena, e lhe perguntou se era verdade que no Museu Nacional no Rio de Janeiro estavam conservados mais de quatro mil registros gravados de música indígena brasileira, pois encontrara uma referência a esse respeito em uma das obras musicais de Villa-Lobos, editada em Paris. Também informou que estava anexando algumas de suas composições, inspiradas nas gravações de música mapuche, e se ofereceu para enviar o material musical francês ou alemão de que Mário necessitasse.

Não se tem mais notícias acerca dos contatos entre Mário de Andrade e os musicólogos chilenos. Mas, pode-se supor que as leituras de Carlos Lavin e o interesse de Domingo Santa Cruz na produção em pesquisa musical de Mário de Andrade tenha servido de veículo para que sua obra saísse das fronteiras brasileiras e, talvez, em alguma medida, ajudasse a alimentar o pensamento musical chileno.

Infelizmente, parece que Mário de Andrade não chegou a ter contato nem conhecimento dos trabalhos do então jovem historiador chileno Eugenio Pereira Salas (1904-1979), que pertenceu ao movimento da Sociedad Bach e compartilhou com Carlos Lavín o trabalho no Instituto de Investigaciones Folkloricas Musicales a partir de 1943. Pereira Salas foi uma figura importante para o movimento de pesquisa musical chileno por sua formação como historiador na França, como aluno de Charles Seignobos, e pela aplicação de seu método de pesquisa em seus

183 Carta de Carlos Lavín, París, 24 may. 1930. IEB-USP: 3951.

${ }^{184}$ A resenha citada não foi encontrada. 
trabalhos ${ }^{185}$. Entre os temas que interessaram a Pereira Salas esteve a música popular, entendida como música folclórica, mas sem todas as características atribuídas a ela pelo folclore. Além disso, escreveu textos provocadores, como Notas para la historia del intercambio musical entre las Américas antes del año $1940^{186}$, sobre a difusão do tango, da rumba e do samba por meio da rádio, do cinema, do disco e dos manuais de baile nos Estados Unidos ${ }^{187}$. Gêneros estes, que muitas vezes foram desprezados por outros intelectuais latino-americanos. Provavelmente, o pensamento musical de Mário de Andrade não estivesse longe do pensamento de Eugenio Pereira Salas, de modo que uma comparação da obra desses dois autores talvez fosse sugestiva para a historiografia musical da América Latina.

\subsection{Carlos Vega e os silêncios argentinos}

A Argentina é um país com um interessante desenvolvimento na atividade musical, pelas suas similitudes, em certos aspectos, com o brasileiro. Durante as primeiras décadas do século XX, tanto Buenos Aires quanto Rio de Janeiro e São Paulo foram centros culturais com fluxos migratórios importantes e configuração de culturas urbanas modernas, que se verão refletidas em seus ambientes musicais.

No entanto, a relação que Mário de Andrade teve com seus colegas argentinos interessados em pesquisa musical é um pouco difusa. Em sua correspondência, nenhuma carta foi encontrada, enquanto que, em sua biblioteca, repousam alguns livros sobre a matéria, também citados em seu «fichário analítico». Entre eles, destacam-se um dos primeiros textos sobre a música colonial argentina, intitulado Nuestra primera música instrumental: datos históricos (1929) ${ }^{188}$, do padre jesuíta Pedro Grenon (1873-1974), assim como a Historia de la Música Argentina.

185 Em 1941, publicou Los orígenes del arte musical en Chile, livro considerado pela historiografia musical como paradigmático para aquele momento (Pereira Salas, Eugenio. Los orígenes del arte musical en Chile. Santiago de Chile: Imprenta Universitaria, 1941). Ver: Pérez González, Juliana. Las historias de la música en Hispanoamérica. Bogotá: Facultad de Ciencias Humanas. Universidad Nacional de Colombia, 2010.

186 Pereira Salas, Eugenio. Notas para la historia del intercambio musical entre las Americas antes del año 1940. Washington: Pan American Unión, Music Division, 1943.

187 González, Juan Pablo. "Los estudios de música popular y la renovación de la musicología en América Latina: ¿la gallina o el huevo?" Trans - Revista transcultural de Música, v. 12,(2008), Disponível em <http://www.sibetrans.com/trans/a100/los-estudios-de-musica-popular-y-larenovacion-de-la-musicologia-en-america-latina-la-gallina-o-el-huevo $>$ (29 octubre 2011).

188 Grenon, Pedro. Nuestra primera musica instrumental: datos historicos. Buenos Aires: Libreria La Cotizadora Económica, 1929. 
Orígen y Características $(1933)^{189}$, do compositor e pianista Arturo Schianca. Esse é um livro profundamente ligado à visão romântica da música popular, no qual Mário de Andrade sublinhou somente um par de dados sobre o Brasil. Entre suas fichas, ele também deixou referências aos artigos publicados no Boletín Latino-americano de Música a respeito da Argentina, ao livro South American Composers (1940) de Nicolas Slonimsky e a um artigo de Leopoldo Hurtado, publicado em La Revue Musicale.

Entretanto, ao ler algumas das publicações sobre música de Mário de Andrade, nota-se que ele leu também outros textos. Ao que parece, seu conhecimento foi alimentado por dois trabalhos do folclorista Juan Alonso Carrizo (1885-1957), Antiguos cantos populares argentinos (1926) ${ }^{190}$ e Cancionero popular de Tucumán $(1937)^{191}$. No exemplar do primeiro, há alguns traços feitos sob o nome de gêneros musicais tradicionais e, na bibliografia, Mário de Andrade sublinhou os items: Juan B. Ambrosetti e seu livro Supersticiones y Leyendas (1917) ${ }^{192}$, e Eusebio R. Castex, Cantos populares. Apuntes lexicográficos (1923) ${ }^{193}$, livros que também repousam em sua biblioteca.

Por outro lado, um dos pesquisadores de maior relevância no âmbito argentino foi Carlos Vega, considerado um dos pioneiros da pesquisa musical tanto por seus êxitos acadêmicos quanto pelo seu papel como professor e gestor cultural. Sua postura perante o estudo da música popular foi crítica diante dos princípios do folclore, distanciando-se dos enfoques tradicionais. Assim como Mário de Andrade, Carlos Vega lutou em seus escritos para encontrar formas teóricas mais eficazes para interpretar a realidade musical latino-americana e, a partir dessa postura, fez interessantes críticas ao conceito romântico de música popular.

Carlos Vega nasceu em Cañuelas, um povoado próximo a Buenos Aires, onde iniciou sua formação como violonista. Chegando à capital argentina, trabalhou

189 Schianca. Historia de la música argentina. Orígen y características.

190 Carrizo, Juan Alfonso. Antiguos cantos populares argentinos. Buenos Aires: Impresores Silla hermanos, 1926.

${ }^{191}$ Carrizo, Juan Alfonso. Cancionero popular de Tucuman. [1937] Buenos Aires: A. Baiocco y cía., 1937.

192 Ambrosetti, Juan Bautista. Supersticiones y Leyendas. Buenos Aires: La cultura argentina, 1917.

193 Castex, Eusebio R. Cantos populares. Apuntes lexicográficos. Buenos Aires: Talleres gráficos «La lectura», 1923. 
de forma voluntária na seção de arqueologia e etnografia do Museu de História Natural Bernardino Rivadavia. Ali, conheceu o estudo etnográfico. Mais tarde, no início da década de 1930, iniciou seus trabalhos de campo pelo território argentino a fim de registrar a música popular, enquanto ocupava o cargo de diretor da Seção de Musicologia do Museu de História Natural (atual Instituto Nacional de Musicologia Carlos Vega), do qual foi fundador. Em 1931, publicou seu estudo e a transcrição do códice colonial de Frei Gregorio de Zuola, intitulado La música de un códice colonial del siglo XVII (1931) ${ }^{194}$, já que, entre seus temas de trabalho, Vega interessou-se pelo estudo da monodia europeia medieval, por considerar que essa questão permitir-lhe-ia entender a interpretação e constituição da música folclórica de seu país ${ }^{195}$.

Em 1937, graças a uma bolsa da Comissão Nacional de Cultura e outra da Unesco, Carlos Vega fez viagens de pesquisa para a Bolívia, Chile, Paraguai e Peru, na busca de continuar registrando música popular. Curiosamente, durante os mesmos anos, em São Paulo, Mário de Andrade organizava a Missão de Pesquisas Folclóricas, que sairia pelo território brasileiro com o mesmo objetivo.

Ainda que semelhante à visão de Mário de Andrade, parece que os dois pesquisadores não entraram em contato por correspondência, a julgar pela ausência de cartas de Vega no arquivo epistolar do escritor paulistano. Não obstante, em sua biblioteca repousam exemplares de três dos livros publicados pelo musicólogo argentino naquele período, com dedicatórias manuscritas para Andrade, o que indica que houve contato e que Mário de Andrade teve algum conhecimento dos trabalhos da Vega.

Um ano antes de iniciar sua viagem de pesquisa, Carlos Vega publicou Danzas y canciones argentinas. Teoría e investigaciones (1936) ${ }^{196}$ um dos livros que enviou a Mário de Andrade —, no qual reuniu diversos artigos e conferências sobre dança e gêneros cantados tradicionais, e acrescentou um estudo teórico sobre a

194 Vega, Carlos. La música de un códice colonial del siglo XVII. Buenos Aires: Imprenta de la Universidad de Buenos Aires, 1931.

195 Behague, Gerard. "Vega, Carlos." Grove Music Online. Oxford Music Online, 2011 e García Muñoz, Carmen e Ruíz, Irma. "Vega, Carlos." Diccionario de la musica española e hispanoamericana, Emilio Casares (ed.) Madrid: Emilio Casaresial, 1999.

196 Vega. Danzas y canciones argentinas. Teorias e investigaciones, un ensayo sobre el tango. 
maneira como pensava a pesquisa das danças populares. Embora o exemplar guardado na biblioteca de Mário de Andrade não possua sinais de leitura, seu título foi incluído na bibliografia do Dicionário musical brasileiro (1989) ${ }^{197}$.

Em 1941, após recopilar uma porção maior de música popular sulamericana, Carlos Vega publicou La música popular argentina. Canciones y danzas criollas ${ }^{198}$, em que usou exemplos musicais de outros países e expôs seu método de análise fraseológica, tirado da música folclórica e aplicado também à música trovadoresca. Esse livro também se encontra na biblioteca de Mário de Andrade, com dedicatória do autor ${ }^{199}$, sem notas de leitura e citado na bibliografia do Dicionário musical brasileiro (1989). Em 1944, Vega publicou Panorama de la música popular $\operatorname{argentina}^{200}$, também enviado a Mário de Andrade e, ao que parece, chegou antes que o escritor paulistano adoecesse e morresse, em fevereiro de 1945, posto que também foi incluído na bibliografia do Dicionário musical brasileiro (1989).

Na obra publicada de Mário de Andrade não há referências aos trabalhos de Carlos Vega, salvo na conferência "Música de feitiçaria", editada por Oneyda Alvarenga em 1963201, em que o autor citou o artigo "Cantos y bailes africanos en el Prata”, e a ilustração que Vega fez sobre o uso da palavra candomblé202. Acredita-se que o nome de Carlos Vega não fosse desconhecido para Mário de Andrade porque, já em 1934, Francisco Curt Lange o mencionou em uma de suas cartas sobre a organização do primeiro tiro do Boletin ${ }^{203}$. Além disso, Renato de Almeida citou-o na segunda edição de sua história da música, a qual Mário de Andrade leu com atenção, e Eduardo Sánchez de Fuentes também o mencionou no artigo "El areito de Anacaona", que faz parte de seu livro Folklorismo. No exemplar desse livro, Mário

197 Andrade. Dicionário Musical Brasileiro.

198 Vega, Carlos. La música popular argentina. Canciones y danzas criollas. Buenos Aires: Imprenta de la Universidad de Buenos Aires, 1941.

199 "A Mário de Andrade — eminente musicólogo — con toda la admiración y simpatía de Carlos Vega. Cangallo 1186 Buenos Aires”.

200 Vega, Carlos. Panorama de la música popular argentina. Con un ensayo sobre la ciencia del folklore. Buenos Aires: Lozada S. A., 1944.

${ }^{201}$ Andrade, ed. Música de feitiçaria no Brasil, p. 26.

202 Vega, Carlos. "Cantos y bailes africanos en el Plata." La Prensa, 16 de octubre 1933.

${ }^{203}$ Carta de Francisco Curt Lange, Montevideo, 9 feb. 1934. IEB-USP: 3898. 
de Andrade sublinhou o parágrafo onde são citadas as palavras de Vega a respeito da a música dos incas ${ }^{204}$.

Por outro lado, sabemos que o autor argentino conheceu uma parte da obra de Andrade porque citou seu artigo "O samba rural paulista" (1937) em Panorama de la música popular argentina (1944) e considerou importante enviar-lhe exemplares de seus livros. Talvez, após um estudo mais detalhado do conjunto da obra de Carlos Vega, possam ser encontrados mais indícios de alguma proximidade com Mário de Andrade 205 .

米

Provavelmente, a curiosidade intelectual de Mário de Andrade em estudar a música como fenômeno humano e estético foi o motor principal para que, em sua biblioteca pessoal, reunissem-se os escritos de alguns dos autores latino-americanos mais representativos da época. É viável afirmar que, apesar dos silêncios documentais, seus livros e cartas possam ser considerados um reflexo bastante completo do momento intelectual que a pesquisa musical na América Latina viveu durante a primeira metade do século XX. Não obstante, a complexidade da biblioteca e do arquivo, bem como a extensão da obra musical de Mário de Andrade, convidam a futuras pesquisas que possam vir a matizar o esquema proposto.

Por outro lado, a difusão de seus escritos, particularmente do Ensaio sobre a música brasileira (1928), fez com que vários estudiosos da música popular entrassem em contato com ele por correspondência, como fruto do reconhecimento acadêmico que o musicólogo brasileiro despertou, dentro e fora de seu país. De forma tácita, esse reconhecimento relaciona-se com o fato de que os pesquisadores que leram seus escritos tenham concordado com Mário de Andrade em aspectos metodológicos ou teóricos do seu pensamento. Talvez, as ideias que configuraram o conceito de música popular de que Mário de Andrade partiu, tenham vibrado na mesma frequência de seus colegas latino-americanos. A seguir, dar-se-á lugar ao

204 Andrade, Nota marginal, In: Sánchez de Fuentes, Eduardo. Folklorismo; artículos, notas y criticas musicales. La Habana: Imprenta Molina y compañía, 1928, p. 15.

É provável que Carlos Vega e Eduardo Sánchez de Fuentes tenham trocado material bibliográfico e, possivelmente, alguma correspondência, pois ambos colegas citaram seus trabalhos.

205 Em Buenos Aires, o Instituto de Investigaciones Musicológicas "Carlos Vega" da Universidade Católica da Argentina é depositário do arquivo pessoal de Carlos Vega, onde se encontra sua correspondência e, talvez, possam existir cartas de Mário de Andrade. 
estudo internalista de suas obras musicológicas, a fim de adentrarmos nas ideias que cercaram tal conceito.

Também é visível que, entre os que escreveram sobre música, circulou uma certa bibliografia que deu notícias do que se estava passando em outros lugares do continente. Trabalhos como o de Francisco Curt Lange e seu Boletín Latinoamericano de Música foram importantes para criar familiaridade entre os estudiosos e facilitar a difusão de suas pesquisas. Mas, apesar da existência desse intercâmbio, é apressado falar em influências intelectuais, particularmente quanto ao manejo e uso do termo música popular. Parece que os contatos foram superficiais, de modo que essa rede não discutiu explicitamente problemas teóricos como a configuração do conceito. Preocupação esta que - como se verá no seguinte capítulo - surgirá somente em meados do século XX. Fica aberta a possibilidade de que a leitura dos trabalhos entre colegas tenha influenciado os inconscientes intelectuais e que as semelhanças e diferenças de seus contextos tenham terminado de perfilar seus conceitos de música popular.

Uma vez esboçado o esquema dos autores que, como Mário de Andrade, encheram de significados o termos música popular, passa-se a estudar a influência da visão de mundo romântica, herdada do século XIX e difundida em território latinoamericano pelos estudos de folclore. Esse será nosso primeiro passo para tentar entender as particularidades que o conceito de música popular teve naquela época. 


\section{"NÃO SOU FOLCLORISTA NÃO": AS VOZES DO ROMANTISMO NA CONSTRUÇÃO DO CONCEITO MÚSICA POPULAR}

Na década de 1930, o compositor Emirto de Lima explicava a quem assistia a uma das sessões do Clube Rotario de Barranquilha,

[...] la verdadera música popular trae consigo todos los perfumes de los campos, la evocación de las escenas hogareñas, entre los humildes, los homenajes tributados a la madre natura, los relatos y hechos de sencillos pastores, labradores y obreros, los acentos vibrantes de los héroes epónimos del trabajo, las conmovedoras y francas expresiones que lanza la masa sufrida en sus luchas, anhelos, amores y tristezas ${ }^{1}$.

Essa era uma das imagens com as quais o folclore costumava ilustrar a existência de uma música popular que era intrinsecamente valiosa por vir de um mundo utópico, onde os laços de comunidade ainda não se haviam quebrado, continuava existindo uma relação harmônica com a natureza e nem a mecanização nem o dinheiro do mundo moderno haviam chegado para perturbar. Essa ideia de música popular, ensinada por Emirto de Lima à sua audiência, era profundamente romântica, e permeou durante toda a primeira metade do século XX o processo de formação do conceito de música popular.

Mário do Andrade e outros intelectuais formaram-se e viveram sob o influxo romântico que imperava em fins do século XIX. Embora alguns tivessem uma opinião própria sobre o que era o romantismo, e até chegassem a criticar alguns de seus axiomas, observa-se que, de maneira subterrânea ou inconsciente, a "visão de mundo" romântica inspirou aspectos do seu pensamento e penetrou na configuração do conceito de música popular da primeira metade do século $\mathrm{XX}^{2}$.

${ }^{1}$ Lima. Folklore colombiano. pp. 152-153.

2 Aqui é retomado o trabalho do Michael Löwy e Robert Sayre Revolta e melancolia. $O$ romantismo na contramão da modernidade, que propõe o romantismo como uma "estrutura mental coletiva" que influiu nos pensamentos artístico, filosófico, político e histórico modernos, e consiste basicamente em uma visão de mundo anticapitalista (Löwy, Michael e Sayre, Robert. Revolta e melancolia. O romantismo na contramão da modernidade. Petrópolis: Editora Vozes, 1995). 
O principal caminho pelo qual o romantismo penetrou na ideia de música popular foi por meio dos debates e princípios teóricos que o folclore propôs, já que durante as primeiras décadas do século XX, esses estudos ficaram conhecidos na América Latina como uma área do saber científica do saber, que prometia resgatar o passado idílico que a modernidade estava destruindo. O romantismo impregnou todo o universo musical e, embora se tenha criado a dicotomia entre música popular e música erudita, a visão romântica instaurou, em ambas categorias, uma escala de valores que enalteceu atitudes como a criatividade espontânea e autêntica.

Ao se considerar que, dentro do conceito de música popular, a visão romântica de mundo teve um papel quase fundador, intuiu-se que sua criação pudesse haver-se dado no momento em que o romantismo tomou força no pensamento musical latino-americano ${ }^{3}$. Neste capítulo, expõe-se um ponto de vista que considera a possibilidade de música popular ter sido uma categoria mental criada pelo romantismo e assumida nas primeiras décadas do século XX na América Latina, para fazer frente à sociedade moderna, e que, desde então, tem sido considerada como uma realidade histórica, e não como um conceito teórico. A partir dessa hipótese, surgiram perguntas sobre o momento de sua criação, e se optou por indagar sobre as categorias taxonômicas que eram usadas para classificar a música antes de se empregar a denominação música popular, buscando-se estudar a gênese da sua construção.

Por meio de bibliografia secundária, estudou-se a maneira como a música foi classificada no passado, e se obteve um dos indícios a respeito da recente criação da música popular como categoria taxonômica importante. O organista, filósofo e musicólogo norte-americano Warren D. Allen (1885-1964) observou que, em princípios do século $\mathrm{XX}$, falava-se de música teórica e prática, mas que as classificações medievais e renascentistas conceberam a música "inspective" ou "especulativa" por um lado e, por outro, a música "ativa" como realidades independentes. Essas divisões, por sua vez, eram ramificações de uma classificação maior: a música das esferas, a música humana e a música instrumental. Além disso,

3 A historiografia latino-americana concorda que o romantismo surgiu na América Latina durante o século XIX, quando as novas repúblicas abriram-se à organização socioeconômica capitalista, e formas antigas coloniais começaram a conviver com as formas modernas. 
Allen ressaltou que a pesquisa barroca esteve interessada no terceiro tipo (a música instrumental), o qual, por sua vez, foi dividido em música "harmônica" e música “orgânica"4.

Allen fez essas observações baseado no estudo de 317 histórias da música europeias, publicadas de 1594 até 1939. Embora ele não se tenha ocupado de procurar especificamente a categoria música popular, fica evidente, por meio de sua análise dos aspectos filosóficos e historiográficos, que o tema do "popular" não parecia preocupar particularmente o pesquisador no passado, talvez não por causa de uma negação do tema - como é comum acreditar —, mas sim por uma inexistência da categoria antes do século XX.

Tendo em vista que nossa tradição teórico-musical é herdeira da europeia, não é de surpreender que essa ausência também se tenha dado em nosso território. Portanto, foram revisadas, em detalhe, algumas das histórias da música latinoamericanas do século XIX, visando a saber se o conceito de música popular foi usado como tal antes do século XX, e em que momentos pareceu ser uma categoria taxonômica importante.

\section{Música popular na América Latina oitocentista: ausência de um conceito?}

No caso latino-americano não se conta com tantas histórias da música anteriores ao século XIX como na Europa, mas os poucos textos existentes também apresentam uma ausência significativa da expressão música popular, e seu uso é relativamente escasso. Em contrapartida, observou-se que os autores estudados fizeram uma diferenciação explícita entre outros dois tipos de música, a música sacra e a música profana, como grupos maiores, e adicionaram algumas particularidades que são revisadas a seguir. Essa grande divisão entre o profano e o sacro foi

\footnotetext{
${ }^{4}$ No estudo de Allen observa-se que, por exemplo, Michael Praetorius, em 1615, classificou a música em música sacra, música fora da igreja e música instrumental na igreja. Em 1690, Wolfgang Caspar Printz classificou em dois grupos: "música sacra" e "música secular". E, no século XVIII a família Bourdelot-Bonnet, por meio da teoria de Aristides Quintilianus, classificou em seis grupos: "música mundana" (música das esferas); "música humana" (a harmonia de um e outro homem, feita com o corpo e controlada pela mente); "música rítmica" (a harmonia consonante que se sente na prosa); "música métrica" (música do verso); "música política" (a organização harmoniosa do estado), e "música harmônica" (ciência e teoria musical). (Allen, Warren Dwight. Philosophies of Music History. A Study of General Histories of Music. [1939] New York: Dover Publications Inc, 1962).
} 
possivelmente uma herança do espírito colonial, quando as metrópoles espanhola e portuguesa patrocinaram enérgicos processos de evangelização e se criou essa dualidade no universo mental da época.

Entre os casos particulares que adotaram a grande divisão entre sacro e profano, está o do músico guatemalteco José Sáenz Poggio que, em sua Historia de la música guatemalteca de la monarquia española hasta finales del ano 1877, destacou essas duas categorias como principais, embora acrescentando que a música também podia ser dividida segundo o seu uso - "la música en el templo, la música en la milicia, la música en el teatro, la música en la sociedad privada, y en la música en fin en medio de la soledad"s —, e com base nessa classificação, organizou os capítulos de seu livro.

Por sua vez, embora na Colômbia Juan Crisóstomo Osorio, em seu artigo "Breves apuntamientos para la historia de la música en Colombia" (1879), não haja proposto um padrão classificatório, ele diferenciou, por meio de seu relato, música indígena e espanhola; música profana e sagrada; música marcial (de banda), canto plano, canto gregoriano e ópera ${ }^{6}$. Esse mesmo autor havia escrito, em 1867, um Diccionario de música, precedido de la teoría jeneral del arte i especial del piano, no qual, na entrada "Música", ensinou que ela dividia-se em "vocal e instrumental, teórico i prática", retomando a tradição teórica renascentista ${ }^{7}$.

Outros autores, como o músico equatoriano Juan Agustín Guerreiro Toro, além de diferenciar o sacro do profano, também distinguiram uma prática musical antiga de outra nova ou moderna; a primeira, próxima à estética musical espanhola e a segunda, à música italiana ${ }^{8}$. Essa diferenciação entre antigo e moderno é corrente

5 Sáenz Poggio, José. "Historia de la música guatemalteca desde la monarquía española hasta fines del año 1877." [1878] Anales de la Sociedad de geografia e historia de Guatemala. v. 22, no. 1-2 (1947) p. 8 ..

${ }^{6}$ Osorio, Juan Crisóstomo. "Breves apuntamientos para la historia de la música en Colombia." Repertorio colombiano. v. III, no. 15 (1879).

José Caicedo y Rojas, um importante literato contemporâneo de Osorio, fez uma crítica ao panorama musical bogotano poucos anos depois, e também dividiu sua apresentação entre ópera, música do templo, música militar e música doméstica ou privada, sem se referir à existência de uma "música popular", nesses termos (Caicedo y Rojas, José. "Estado actual de la música en Bogotá." [1886] In: Hjalmar de Greiff, et al. (ed.), Textos sobre música y folklore, Bogotá: Instituto Colombiano de Cultura, 1978).

7 Osorio, Juan Crisóstomo. Diccionario de música, precedido de la teoría jeneral del arte $i$ especial del piano, Bogotá: 1867, p. 75.

8 Guerrero Toro, Juan Agustín. La música ecuatoriana desde su origen hasta 1875. [1876] Quito: Banco Central del Ecuador, 1984. 
em vários momentos da história musical, nos quais surge uma prática que visa diferenciar-se da anterior e se legitimar como novidade, como aconteceu em fins do século XVI com a prima pratica (representada por Giovanni Artusi, conhecido como o maior reacionário da história da música europeia) e a seconda pratica (com Claudio Monteverdi como um dos pioneiros do barroco musical).

No caso latino-americano, a diferenciação feita por Guerreiro Toro é coerente com a forte influência que a ópera italiana estava exercendo sobre o meio latino-americano, graças à presença das companhias itinerantes que percorriam o território. $\mathrm{O}$ auge da ópera não passou desapercebido de seus contemporâneos: ao contrário, criou uma mudança estética profunda no ambiente musical e, com ela, algumas polêmicas que ocuparam a mente dos críticos e músicos da época, em relação a aspectos como seu uso, indevido ou não, nas igrejas.

Curiosamente, embora nas fontes revisadas o conceito música popular não tenha sido usado como tal, o conceito de povo foi usado com alguma frequência e com certa imprecisão. $\mathrm{O}$ único autor que se deteve em especificar quem compunha esse povo ao qual se referia foi o equatoriano Juan Agustín Guerreiro Toro, quando narrou que, depois do fechamento da Sociedad Filarmónica em 1852, o reviver da Sociedad de Santa Cecilia foi "una especie de oposición del pueblo", composto por

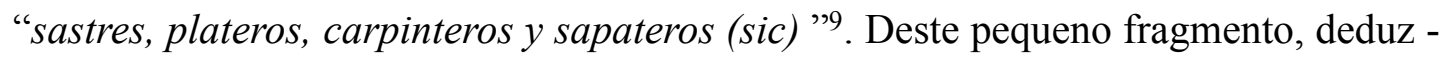
se que, para o autor, o conceito povo não excluía as pessoas da cidade e que, de fato, talvez tivesse um caráter mais urbano que rural, pois os ofícios mencionados davamse tipicamente nas urbes. Pela maneira como Guerreiro Toro construiu sua argumentação, parece que o sentido da categoria "pueblo", nessa frase, opõe-se ao de "nobleza".

Essa relação nobreza-povo reflete-se nas definições que, em espanhol, trazia o Diccionario de la Academia de la Lengua Española de 1780 a 1899. A palavra pueblo foi definida como " la gente común y ordinaria de alguna ciudad o

\footnotetext{
${ }^{9}$ Ibid., pp. 35-36.
} 
población, a distinción de los nobles"10. Ao que parece, tal definição referia-se a uma classe social determinada simplesmente pelo seu contrário: a nobreza. Por sua vez, a nobreza era definida, nos mesmos dicionários, como "Lustre, esplendor, o claridad de sangre, por la cual se distinguen los nobles de los demás del pueblo, la qual, ó viene por sucesión heredada de sus mayores, o se adquiere por las acciones gloriosas" $" 11$.

A partir dessas duas definições, estima-se que as palavras nobleza e pueblo corresponderam a duas categorias abstratas, cujos limites, em princípio, não eram materiais, mas sim imaginários; além disso, provinham de um contexto medieval europeu e, embora mantivessem certa vigência no contexto latino-americano colonial, não descreviam a realidade social e racial que se vivia. Ao que parece, deve-se esperar o apogeu do romantismo e do nacionalismo nos países de fala hispânica para encontrar, dentro do conceito de povo, a ideia de comunidade. A primeira vez que essa ideia apareceu nos dicionários, foi na edição de 1899, na qual pueblo era, dentre outras acepções, um “conjunto de personas de un lugar, región o pais"12.

Em 1865, Juan Agustín Guerreiro Toro anotou que uma comissão científica da Espanha pediu-lhe para colecionar "todas las melodías indianas y populares, para llevarlas al museo de ciencias naturales de Madrid"13. Não se conhece o paradeiro dessas melodias, para se ouvir o que era chamado de "popular", mas, se for considerada a ideia de pueblo enunciada anteriormente, seria de se pensar que essas melodias não eram rurais, como possivelmente se entenderia na atualidade.

10 Esta é a terceira acepção dada pelo Diccionario de la lengua castellana compuesto por la Real Academia de la lengua española reducido a un tomo para su más fácil uso, em 1780, que se manteve até a edição de 1899. Ao revisar todas as edições desse dicionário, notou-se que, durante todo o século XIX, deu-se como primeira acepção da palavra povo "el lugar o ciudad que está poblado de gente" e, como segunda acepção, "el conjunto de gentes que habitan el lugar". Somente na edição de 1837 adicionou-se uma quarta acepção: "Nación, por conjunto de", o que é coerente com a formação dos Estados-nação.

11 Real Academia Española. Diccionario de la lengua castellana compuesto por la Real Academia Española, reducido a un tomo para su más fácil uso, Madrid: 1780.

${ }^{12}$ Figueiredo, Antonio Candido de. Novo diccionario da lingua portuguesa, Lisboa: 1899.

Há que se ter em conta que sua inclusão foi tardia em relação ao fenômeno do nacionalismo. Entretanto, isso não significa que até aquele momento o vocábulo não fosse usado; ao contrário, seu uso com essa definição já era tão comum na língua que o dicionário a incluiu nessa data. Esses dicionários não eram prescritivos, e sim descritivos.

${ }^{13}$ Guerrero Toro. La música ecuatoriana desde su origen hasta 1875. [1876] p. 12. 
Por outro lado, em geral, os autores do século XIX não foram alheios aos fenômenos musicais que estavam acontecendo em suas pequenas cidades e que, no século XX, serão considerados como música popular urbana - tipo de música que tinha vários detratores. Por exemplo, o músico guatemalteco José Sáenz Poggio, em 1878 , mencionou as caixas de música que existiam na Guatemala entre as quais,

[...] hay una muy notable, porque sólo contiene piezas de hijos del país. Don José Maria Valero, comerciante de esta capital, la mandó fabricar a París. Las piezas que contiene son: El Paraiso perdido, Ayer te ví. La media noche, Yo sé lo que te digo, valses por don Salvador Iriarte: Felipa, La encantadora, polkas por el mismo autor: Un sueño, El Lamento, valses por don Cástulo Morales: Teresa, Margarita, polkas, por don Bernandino Orla, etc. ${ }^{14}$

O uso dessas caixas e o repertório mencionado fazem referência à música que se ouvia nas cidades, cujos gêneros como a valsa e a polca, eram muito comuns em todo o continente.

Assim mesmo, Juan Crisóstomo Osorio, no ano seguinte, mencionou em seu texto alguns gêneros musicais e instrumentos que posteriormente seriam considerados como próprios da cultura popular colombiana, como é o caso dos gêneros bambuco, currulao, torbellino, guabina e galerón, e instrumentos como marimba, carraca, chuchas, alfandoque, maracas, fotutos, tamboriles, tiple, bandola e violão. Embora posteriormente tenha ocorrido, no contexto colombiano, uma forte divisão e polêmica entre a música de corte acadêmico e a chamada música popular, observa-se que nesse texto precoce seu autor não teve receio de prestar atenção a ambos igualmente.

Um caso similar é o de Ramón de la Plaza, que em seu livro, Ensayos sobre el arte en Venezuela (1883), tampouco usou o conceito música popular, mas anexo às partituras, incluiu uma coleção de 43 “Aires Nacionales de la República de E.E.U.U. de Venezuela", entre as quais encontra-se o "Joropo popular o fandango redondo", que, posteriormente, também será considerado como gênero popular. Algo similar aconteceu em Cuba, onde o compositor Laureano Fuentes, ao escrever Las artes en Santiago de Cuba (1893), incluiu algumas menções a gêneros musicais que depois se tornaram emblemáticos da música popular cubana, como o danzón, a guaracha, o bolero e a dança.

\footnotetext{
14 Sáenz Poggio. "Historia de la música guatemalteca desde la monarquía española hasta fines del año 1877." [1878] p. 52.
} 
Tanto no trabalho do cubano Laureano Fuentes quanto no do venezuelano Ramón de la Plaza, denunciam duas situações ocorridas nos meios musicais e que, no futuro, gerarão grande mal-estar: a profissionalização musical, dada em conservatórios e academias de música, e a entrada da música no mercado do entretenimento.

Laureano Fuentes, reconhecido compositor de óperas e zarzuelas, centralizou seu escrito nos músicos e compositores que, de uma forma ou de outra, participaram dos espetáculos cênicos, e reconheceu ter deixado fora de seu relato outros músicos porque:

[...] seria tan ridículo comparar a Rossini con trescientos mil especuladores que se dan el nombre de músicos, como llamar físicos y químicos a los prestidigitadores, como confundir la superstición con los presentimientos del alma humana ${ }^{15}$.

Para saber quem foram os músicos "especuladores" que Fuentes considerou indignos de figurar em seu relato, seria preciso esquadrinhar os arquivos e bibliotecas cubanas. Não obstante, intui-se que se tratava de músicos formados na tradição oral, posto que Fontes mostrou-se muito satisfeito com a fundação de conservatórios e escolas de música, que considerou uma mostra de progresso, e foi detalhista ao descrever a formação acadêmica de seus biografados. Esse entusiasmo faz pensar que, junto à valorização que Fuentes fez da educação musical formal, pode ter existido um certo desdém em relação aos âmbitos de reprodução não institucionalizados.

Também na Venezuela, Ramón de la Plaza, que era violoncelista e diretor do Instituto de Belas Artes de Caracas, ao se referir ao músico José G. Núñez, descreveu-o como um "artista de nota", o que significa, implicitamente, a existência de outros músicos que não sabiam ler partituras e que, certamente, estavam fora das instituições de formação musical. Com essas referências rápidas de Ramón de la Plaza e Laureano Fuentes, pensa-se que, já para o final do século XIX, nas cidades onde se fundaram academias musicais e conservatórios, vinha sendo criada uma diferenciação entre os músicos formados e os músicos que continuaram aprendendo música por meio tradição oral — aqueles que prescindiram do solfejo. Sobre a

15 Fuentes Matons, Laureano. Las artes en Santiago de Cuba. [1893] La Habana: Editorial letras cubanas, 1981, p. 182. 
importância que essa diferenciação vai trazer para a conformação do conceito de música popular, voltaremos mais adiante.

Outro dos fenômenos já presentes em Caracas, e mencionado rapidamente na obra de Ramón de la Plaza, é a entrada da música no mercado e suas consequências nefastas - na opinião do autor —, o qual se converterá em um dos leitmotiv da literatura musical da primeira metade do século XX sobre a música popular urbana. De acordo com o autor:

[...] no es solo la música, que también las demás artes siguen idéntico camino [...]: el espíritu del mercantilismo invade cruel las regiones del arte para ver de corromperlo y hundirlo en la decadencia ${ }^{16}$.

Não é estranho que, dentre os autores já citados, sejam Laureano Fuentes e Ramón de la Plaza os que fizeram alguma menção a esses dois fenômenos, pois, em geral, os demais autores das primeiras histórias da música viveram em cidades pequenas, à exceção, justamente, de Santiago de Cuba e Caracas, onde a vida cultural teve maiores proporções que em Quito, Bogotá e Guatemala. Embora todos os autores estudados tenham vivido e escrito nas capitais de seus países, estas três últimas não tinham alcançado o crescimento nem a modernização que em finais do século XIX estava-se vivendo em outras capitais latino-americanas como Santiago do Chile, México, Buenos Aires e Rio de Janeiro. Portanto, fica faltando um trabalho que inclua documentação produzida nessas capitais para comparar com os textos aqui analisados.

Em síntese, observou-se que, nos escritos consultados da segunda metade do século XIX, seus autores hispanófonos não usaram o conceito música popular para caracterizar ou definir um tipo de música, mas mostraram interesse pela música que alguns um anos depois será chamada popular, tanto pelo folclore quanto pela atual historiografia da música popular urbana. Fica aberta a pergunta sobre a inexistência do conceito música popular no século XIX hispano-americano, para que novas pesquisas averiguem outro tipo de fonte e comparem suas conclusões.

Com a questão sobre a ausência do conceito de música popular no século XIX a intenção foi estudar as fontes da América de fala portuguesa. Não obstante,

\footnotetext{
16 Plaza, Ramón de la. Ensayos sobre el arte en Venezuela. [1883] Caracas: Imprenta al Vapor de "La Opinion Nacional", 1983, p. 12.
} 
como a historiografia musical brasileira não registrou nenhuma história da música de grande fôlego durante o século XIX, foi usado outro tipo de documentação, e essa pergunta foi deixada em aberto.

De acordo com o historiador de música Paulo Castagna, durante o período colonial brasileiro conviveram duas categorias de música "cuja diferença, está em sua função e não na sua aparência": a música dos povos indígenas, africanos e europeus, "[...] que a partir do início do século XX começou a ser definida como folclórica ou popular”, e a música produzida por músicos profissionais “[...] que a partir de início do século XX começou a ser chamada «erudita» ou «artística»"17. Isso indicaria que, no caso brasileiro, durante o período colonial, tampouco se usou música popular como um critério classificatório importante, e que assim seria até o século XX, quando essa ideia surgirá com destaque. Por ter sido assim, seria de se imaginar que o passo entre esses dois momentos teria ocorrido durante o século XIX, justamente um período do qual não possuímos histórias da música nem dicionários musicais brasileiros que nos auxiliem na pesquisa.

Longe de pretender esgotar o assunto, mas somente a título de curiosidade, foram usados dois contos de Joaquim Machado de Assis (1839-1908) para ilustrar a possível ausência do conceito música popular no século XIX também no caso brasileiro, assim como no resto da América Latina. Com esse exercício, percebeu-se que era preciso diferenciar a existência do conceito dentro do vocabulário da época, da presença de práticas musicais similares às que hoje denominamos como populares. Quer dizer, o não uso da categoria música popular no Brasil oitocentista não significava a inexistência de uma prática musical urbana nova, pois justamente será ela que uns anos depois receberá o epíteto de popular e criará ambiguidade com o popular-camponês construído pelo folclore.

De acordo com a análise que José Miguel Wisnik fez do conto "Um homem célebre”, de Machado de Assis, já nas duas últimas décadas do século XIX havia uma:

fratura, operante no meio cultural brasileiro, entre o repertório da música erudita, que está longe de fazer parte de um sistema integrado de autores, obras, público e

17 Castagna, Paulo. "Música na América portuguesa." In: José Geraldo Vinci de Moraes, et al. (ed.), História e Música no Brasil, São Paulo: Alameda, 2010. 
intérpretes, e a emergência de um fenômeno novo, uma música popular urbana que desponta para a repercussão das massas, a identificação com a demanda do público e a normalização como mercadoria ${ }^{18}$.

O fato de que, para as últimas décadas do século XIX, seja correto distinguir as duas práticas musicais, não significa que se possa transpor os conceitos de erudito e popular usados na atualidade. De fato, Machado de Assis não usou, nesse conto, nenhum dos dois conceitos para fazer a diferenciação descrita. Em vez disso se referiu à música que hoje se chama de erudita como "coisa ao sabor clássico"19 e "conserto de artista" 20 e à polca, simplesmente como polca.

No conto "O machete" (1878), também analisado por Wisnik, Machado de Assis tampouco usou a expressão música popular, mas sim se referiu a essa nova música, pela boca de um de seus personagens, como "É outro gênero...", e na linha seguinte o narrador confirmou: "Era efetivamente outro gênero, como o leitor facilmente compreenderá" 21 ; mais adiante, chamou esse "outro gênero" de "cantiga do tempo e da rua, obra de ocasião"22, e fez a diferenciação entre um tipo de música que era arte (hoje seria entendida como música erudita) e outra que era passatempo (hoje seria entendida como música popular urbana) ${ }^{23}$.

De acordo com Wisnik, naquele momento não era tão evidente a distância entre o erudito e o popular porque um dos traços definidores da formação musical brasileira é precisamente a permeabilidade entre diferentes mundos musicais, como bem o exemplificam os contos $\operatorname{citados}^{24}$. Na realidade, essa permeabilidade não é própria do caso brasileiro, já que em outros âmbitos latino-americanos também se observa que, enquanto no século XX os intelectuais esforçaram-se por diferenciar a nível teórico - a música popular da erudita, o cotidiano do músico caracterizou-se pela sua facilidade para se mover entre ambientes socialmente diferentes, e pelo seu ecleticismo ao se apropriar das tradições musicais que o rodeavam; essa permeabilidade faz com que exista uma distância grande entre os parâmetros

\footnotetext{
${ }^{18}$ Wisnik, José Miguel. Machado maxixe: o caso Pestana. São Paulo: Publifolha, 2008, p. 15.

19 Assis, Machado de. "Um homem célebre." [1888] Várias Histórias, Rio de Janeiro / Belo Horizonte: Livraria Garnier, 1999, p. 65

${ }^{20}$ Ibid., p. 70.

${ }^{21}$ Assis, Machado de. "O machete." [1878] Contos. Uma antologia, São Paulo: Companhia das Letras, 1998, p. 248

${ }^{22}$ Ibid.

${ }^{23}$ Ibid., p. 251.

${ }^{24}$ Wisnik. Machado maxixe: o caso Pestana. p. 45.
} 
conceituais referidos e aquilo que os músicos faziam em seu dia a dia, nos quais esses limites são apagados e algumas vezes, pouco importam ${ }^{25}$.

Continuando com o caso brasileiro, duas décadas depois de Machado de Assis ter escrito seus contos, o bibliotecário da Escola Nacional de Música, Guillermo Pereira de Mello, publicou a primeira história geral da música do Brasil, em que usou reiteradas vezes a expressão música popular como uma categoria importante em seu trabalho. O objetivo de seu livro foi o de mostrar as influências que configuraram a música popular brasileira e como esta foi constituindo-se ao longo do tempo ${ }^{26}$. Para alcançar seu propósito, outorgou um lugar dentro de seu relato a cada uma das manifestações musicais de que teve notícia, e "pôs sob o mesmo guarda-chuva" popular brasileiro, gêneros como o bolero e a habanera (que, mais tarde, serão polêmicos por sua "não brasilidade") e a modinha, o lundu, o maxixe e a tirana (posteriormente considerados como música popular urbana brasileira). Em seu livro também compartilharam o cenário, a música religiosa ensinada pelos jesuítas, a música indígena, a ópera nacional e a música sinfônica, com gêneros camponeses como os congos, bumba meu boi e aboios. De um modo similar ao de seus colegas hispano-americanos do século XIX, Pereira de Mello ocupou-se de uma grande diversidade de gêneros musicais sem exclusividades, gêneros que depois serão organizados entre erudito ou popular, e entre brasileiro ou estrangeiro. Em suas palavras, o autor justificou essa inclusão dizendo:

Não é somente entre os costumes e folgares de principio religioso ou hieratico que se baseam os cantares tradicionais do povo brasileiro: as cantigas de rua os cantares de roda, as cantilenas de berco, as canções bacchicas, os aboiares dos vaqueiros, os arrascares dos campeões e muitos outros trovadores que já vão cahindo em desuso, taes como: a canção do figueiral, e xacara do cego, o Bernal francez, D. Silvana, e o Conde D. Alberto, etc., constituem outros tantos especimens de músicas populares que fazem parte de nossa tradição ${ }^{27}$.

Além disso, parece que Pereira de Mello entendeu que toda a música ouvida no Brasil cabia sob o epíteto música popular brasileira, em uma espécie de

\footnotetext{
${ }^{25}$ Para o Brasil, essa mobilidade está descrita em: Viana, Hermano. O mistério do samba. Rio de Janeiro: Jorge Zahar Editor, 1999.

Para um estudo de caso acerca dos trânsitos do músico colombiano Anastasio Bolivar (ca. 1895-1949), ver: Cortés Polanía, Jaime. "El Tango Chocoanita de Anastasio Bolívar: un augurio musical de los años 1920s en Colombia." A Contratiempo n. 15 (2010), Disponível em <http:// acontratiempo.bibliotecanacional.gov.co/?ediciones/revista-15/> (Julio 2011).

${ }^{26}$ Mello, Guilherme Theodoro Pereira de. A música no Brasil desde os tempos coloniais até o primeiro decênio da república. Bahia: Typografia de S. Joaquim, 1908, p. 6.

${ }^{27}$ Ibid., pp. 79-80.
} 
sinonímia entre popular e nacional. Por ora, basta esclarecer que essa proximidade conceitual entre música nacional e música popular foi comum no continente durante esse período, graças à influência romântica nacionalista que se impunha. No caso de Pereira de Mello, seu trabalhou foi feito justamente sob essa premissa, já que, na sua opinião, a constituição da música popular brasileira deu-se graças a um tipo de "espírito" característico que penetrava toda criação musical, embora possuísse heranças africanas, portuguesas ou indígenas, e lhe dava certo tom de homogeneidade nacional ${ }^{28}$.

Apesar da abertura temática empreendida por Pereira de Mello e do caráter teórico de sua ideia de música popular, chama a atenção o fato de que existam indícios em seu livro de um diferenciação escamoteada entre três tipos de música, às quais dedicou diferentes níveis de atenção. Ao se referir ao fim da guerra com o Paraguai, o autor escreveu que, no Rio de Janeiro, as modinhas nacionais foram substituídas por "ímpias e indecentes cançonetas tão enthusiásticamente applaudidas pela mocidade alegre e folgazã nas revistas theatraes e nos cafés cantantes" 29 , às quais não voltou a se referir, e que possivelmente descreviam uma prática musical nova, que algumas décadas depois será denominada popular urbana. Também diferenciou "as músicas populares, cujo rhytmo mais ou menos curto, regular e persistente, é o único que fala ao sentimento affectivo do povo e que por elle é comprehendido" de outra música, "cujas composições são feitas senão unicamente para os artistas pelo menos para as pessôas de gosto mais ou menos educados" ${ }^{\prime 30}$. Talvez, com a primeira, referisse-se ao que viria a ser chamado de música popular, em relação a um povo utópico, e com a segunda descrição, à chamada música erudita.

Por outro lado, a presença do termo música popular, e de algumas práticas associadas a ele no início do XX, ficou consignado no Dicionário Musical, de Isaac Newton, publicado em Maceió em 1904, o que poderia fazer às vezes de elo entre a

28 Era comum, nas histórias da música latino-americanas, considerar que a música de seus países havia surgido da fusão entre os elementos indígenas, negros e europeus. Esse mesmo argumento costumaram introduzir estudos históricos musicais posteriores, como é o caso do livro Brasil Sonoro, de Mariza Lira, cujo primeiro capítulo é uma síntese dos argumentos apresentados por Pereira de Mello, 30 anos antes.

${ }^{29}$ Ibid., p. 296.

${ }^{30}$ Ibid., p. 237. 
classificação musical herdada do século XIX e as classificações do século XX. Na entrada "Música", o autor mencionou a classificação entre os gêneros sacro, música dramática e de concerto, segundo os parâmetros oitocentistas. Curiosamente, o dicionário traz outras entradas para outros tipos de música que certamente estavam vigentes, como "música de baile pastoril", "música de câmara", "música de igreja", “música especulativa”, "música instrumental”, “música vocal” e "música militar". Embora Newton não tenha considerado música popular como uma categoria taxonômica que merecesse uma entrada própria, ele apontou o uso da palavra "popular" no âmbito musical e disse que servia para significar "que anda por festas populares, tocando por funcções. Se diz também d'aquelle que, mui limitados conhecimentos, tem d'arte" ${ }^{\prime 31}$. Como se pode constatar, dá a impressão de que a expressão limitou-se a qualificar um tipo de músico em particular, e não sua música, o que é ligeiramente diferente do uso moderno da palavra. Ademais, essa definição enfatiza os escassos conhecimentos atribuídos ao músico popular, mas "conhecimentos limitados", em comparação com quem? Esse é o tema da próxima seção.

Por ora, observou-se que o termo música popular esteve presente, no caso brasileiro desde os primeiros anos do século XX e, apesar do seu significado volátil — provavelmente por causa do escasso número de fontes usadas —, sabe-se que ele começou a fazer parte do vocabulário da época. Além disso, observou-se que, desde o início do século XX, a música popular foi tratada mais como uma categoria teórica do que como um tipo de música concreta, conforme se percebe no escrito de Guilherme Pereira de Mello. No restante deste capítulo, buscar-se-á identificar as bases sobre as quais se sustentou a noção de música popular, primeiro a partir da relação que houve entre as categorias música popular e música erudita, a qual ajudou na caracterização da primeira, e depois, por meio da sua relação com o início dos estudos de folclore.

\section{Entre o popular e o erudito}

\footnotetext{
${ }^{31}$ Newton. Diccionario musical. p. 188.
} 
Desde as primeiras décadas do século XX, na América Latina era evidente a existência de uma diferença entre uma música popular e outra de tipo europeu, chamada habitualmente "erudita", em português e "clásica" ou "académica", em espanhol. Era comum encontrar rastros dessa divisão na mentalidade dos autores, que, baseados nela, atribuíram certas características à música popular. Essa dicotomia entre o popular e o erudito pode estar relacionada à distinção entre uma cultura musical institucionalizada e escrita, e outra de tradição oral e alheia às instituições musicais da época. Vejamos.

Em 1915, o músico colombiano radicado em Buenos Aires, Santos Cifuentes, publicou, no jornal argentino Correio musical sud-americano, um artigo no qual descreveu a situação musical de seu país de origem e resumiu a divisão entre a música popular, de caráter nacional e iletrado, e a música erudita, difundida pelas instituições musicais.

Nesse artigo, o músico usou as categorias música clássica, gênero religioso e gênero popular ou música popular para organizar seu discurso. Sob a primeira categoria, referiu-se à música europeia representada por compositores como "Haydn, Mozart, Beethoven, Schumann, Medelssohn, Brahms, Jadassohn, Chopin, Liszt, Schubert, sin exclusión de la escuela italiana" ${ }^{2}$, que era ensinada e difundida pelo Conservatório Nacional de Música e sua orquestra, instituições com apoio governamental.

Sob o epíteto de popular, Santos Cifuentes referiu-se a instrumentos "antiguos que se usan aun en los campos", como o capador ou flauta de Pã, o alfandoque ou chucho e a carrasca, e a instrumentos de corda, "tocados por las manos, delicadas como azucenas, de aristocráticas damas", como a bandola, o tiple e o violão. Com esta alusão às "aristocráticas damas", ele deixa ver que, sob a categoria popular, não excluiu certas práticas da classe alta. Também mencionou como representantes da música popular os gêneros bambuco, pasillo, danza e danzón, e o compositor Emilio Murillo (1880-1942), cuja "fama ha salvado los límites del suelo patrio, y entre el repertorio de pianolas y gramófonos encuéntrase muchas de sus producciones". Santos Cifuentes, não obstante, ressaltou que esse

\footnotetext{
${ }^{32}$ Cifuentes Rodriguez, Santos. "La música en Colombia." El correo musical sud-americano. v. 26, (1915) p. 10.
} 
músico tinha uma debilidade ou defeito: "ausencia de cierta preparación técnica, indispensable para dar a las ideas [...] un desarrollo y una forma más artísticos" 33 . Além disso, Cifuentes reclamou perante seus leitores sul-americanos que o Conservatório Nacional de Música só prestava atenção à música erudita e mantinha abandonada a música nacional, quer dizer, a música popular.

Esse artigo tocou em um dos pontos que serão nevrálgicos nas discussões que se seguiram a ele, tanto no âmbito colombiano quanto em outros países latinoamericanos: a diferenciação entre uma música de tradição oral, com raízes em ambientes camponeses ou semiletrados urbanos, e a música ensinada nas escolas de música, de tradição escrita e europeia. A primeira foi denominada música popular e tratada usualmente como sinônimo de "música nacional", e a segunda, música clássica e considerada como a antítese do nacional.

No caso colombiano, por exemplo, essa distinção criou dois grupos inconciliáveis de músicos. Um, liderado por Emilio Murillo, músico bogotano, próximo aos músicos das classes populares da cidade, com uma formação musical básica, recebida na Academia Nacional de Música, trabalhador da maior fábrica de cerveja do país, de tendências políticas liberais e usuário da precoce indústria discográfica para difundir a música feita por ele e por seus seguidores. E o outro grupo, encabeçado por Guillermo Uribe Holguín (1880-1971), músico de classe alta, formado na mesma Academia Nacional de Música, mas com estudos posteriores na Escola Cantorum de Paris, diretor do Conservatório Nacional de Música, de tendências políticas conservadoras e compositor de profissão. A relação entre esses dois músicos era "como água e azeite" e, em que pese terem em comum o interesse pela constituição de um repertório nacional, geraram uma polêmica, entre 1924 e 1930, que radicalizou suas posturas e as de seus seguidores, diante da maneira como cada um entendeu o nacional ${ }^{34}$.

É claro que o processo de institucionalização do ensino musical sob o cânone europeu, e mais exatamente o francês, ocorreu na América Latina com a fundação de escolas de música e conservatórios do século XIX, e que esses espaços

33 Ibid., p. 6

34 Duque, Ellie Anne. "Emilio Murillo. Compositor colombiano (1880-1942)." Biblioteca Luis Ángel Arango. Banco de la República, Disponível em <http://www.banrepcultural.org/blaavirtual/ musica/blaaaudio/compo/murillo/indice2.htm>, (20 mayo 2011). 
não acabaram com os ambientes onde a música continuava a ser aprendida por tradição oral, como acontecia entre os camponeses, grupos étnicos e alguns grupos urbanos. Embora muitas vezes os músicos circulassem - e continuam circulando entre esses variados ambientes, criou-se, no início do século $\mathrm{XX}$, uma escala de valores ambígua que, por um lado, menosprezou socialmente a música de tradição oral diante da música escrita que chegava da Europa, e era considerada sinônimo de progresso, mas, por outro lado, surgiu um movimento romântico que lutou pela valorização e recuperação das tradições orais, fazendo-as centro das identidades nacionais ${ }^{35}$.

Ao que parece, essa distância entre o institucional e o não institucional não foi tão marcada durante o período colonial. Em termos gerais, tanto na América espanhola quanto na América portuguesa coloniais, conviveram três tipos de repertório: o repertório tocado nas igrejas — âmbito institucional que acolheu a atividade musical - e escrito em partituras; o chamado repertório profano, pouco conhecido hoje, tocado em festas públicas e privadas sob o controle das autoridades coloniais e, o repertório tocado pelos grupos étnicos segundo seus usos, repertório desconhecido atualmente. É provável que uma das causas para que esta diferença entre o institucional escrito e o oral não fosse tão definitiva, estivesse relacionada ao fato de que a partitura tinha um caráter mais mnemotécnico, conforme as tradições musicais renascentista e barroca, em relação ao que teve nos séculos XIX e XX. Uma porcentagem menor do que o intérprete fazia em seu instrumento era preestabelecida em notação musical, pois muitos outros elementos eram transmitidos via tradição oral. À medida em que o repertório clássico e romântico chegou à América Latina, tornou-se cada vez mais forte o apego à partitura como veículo de perpetuação de uma música canônica, e o pensamento musical acabou diferenciando, com maior afinco, o oral do escrito.

Essa passagem foi mais ou menos esboçada em 1930, pelo regente de banda e compositor Segundo Luis Moreno (1882-1972), em seu escrito “La música en

35 De acordo com o Löwy e Sayre, o romantismo "representa uma crítica da modernidade, isto é, da civilização capitalista moderna, em nome de valores e ideais do passado". Essa modernidade é entendida como o fenômeno que nasceu na Europa com a Revolução Industrial e a generalização da economia de mercado, e que gerou, em alguns indivíduos, a "convicção dolorosa e melancólica de que o presente carece de certos valore humanos essenciais que foram alienados" (Löwy e Sayre. Revolta e melancolia. O romantismo na contramão da modernidade. pp. 34-40). 
Ecuador", em cuja história musical, fechou seu relato sobre o fim do período colonial e a configuração da república dizendo:

Trescientos años [del periodo colonial] hubieron de transcurrir para que la música popular de este país se presentara revestida ya de la tonalidad moderna. Y digo música popular, porque entonces no había otra, ya que jamás se pensó en fundar aquí una escuela, una academia ni nada en donde se enseñara el divino arte sobre el fundamento firme de los conocimientos científicos ${ }^{36}$.

Esse autor exemplificou a ideia de que a música popular estava desligada das instituições de ensino e de que, portanto, foi com a criação de tais organismos que surgiu a diferença entre uma prática popular anterior e uma prática acadêmica nova, "revestida ya de la tonalidad moderna".

No México, também, duas histórias da música enunciaram a divisão oral/ popular e acadêmica/erudita na primeira metade do século XX. Em 1928, o literato modernista Rubén M. Campos (1871-1945) ressaltou que uma das características da música popular a que se referia era que,

[...] está compuesta por un músico que no ha estudiado armonía ni contrapunto, que ignora las reglas de la composición musical, que no ha oído jamás a ninguna agrupación de música de cámara y no tiene conocimiento de las altas formas musicales ${ }^{37}$.

Campos ressaltou a distância que existia entre a música popular e o mundo acadêmico como uma das principais características da primeira.

Cinco anos depois, essa mesma distância foi sublinhada em Nociones de la historia de la música mejicana (1933), do médico e escritor Miguel Galindo. O autor era contrário ao ensino de música popular nos conservatórios, a diferença da maioria de autores quem reclamavam justamente a inclusão do repertório popular no ensino acadêmico, e que se converteria em uma das bandeiras do movimento folclorista de meados do século XX. De uma perspectiva diferente, Miguel Galindo pensava que era,

[...] una fortuna que la música campesina no haya tenido el desgraciado honor de traerse a los conservatorios, de interpretarse con notas escritas y encajarla en la escala de siete sonidos. El olvido erudito le dejó el tiempo suficiente de arraigar bien en las conciencias, en las conciencias campesinas, y llegar, aunque miserablemente, a la edad adulta y alcanzar nuestro tiempo en que [...] el fanatismo «folkle-lorico», está dirigiendo hacia ella las miradas sorprendido [...]

36 Moreno, Segundo Luis. "La musica en el Ecuador." El Ecuador en 100 años de independencia, Quito: [s.e.], 1930, p. 229

${ }^{37}$ Campos. El folklore y la música mexicana. pp. 86-87. 
de la sugestión arrobadora de esa música popular, que lejos, muy lejos de los estrechos carriles de la técnica erudita se ha desarrollado y vivido en el valle y la montaña ${ }^{38}$.

Miguel Galindo é um autor que chama a atenção porque fez observações a respeito do desenvolvimento musical de seu país um tanto divergentes das de seus contemporâneos. Por exemplo, esse médico mexicano foi o único autor que suspeitou que a divisão entre acadêmico e erudito podia ser um fenômeno recente. Sem um conhecimento profundo da sociedade colonial, sua suspeita foi formulada e solucionada assim:

Es posible que en esta época haya nacido, o más bien se haya recrudecido esa especie de odio entre lo popular y lo erudito, a lo que no debe haber contribuido en no pequeña parte la división de las clases sociales, pues a juzgar por las crónicas y pinturas de las costumbres de los días que estudiamos [siglo XVII], la ciudad de México, que era «la gran ciudad» ni era tan grande ni tenía una población que pudiera comparase con la actual ${ }^{39}$.

A maioria dos autores latino-americanos, ao contrário, tinha muito clara a ideia de que existia uma antiga diferenciação entre popular e erudito. Por exemplo, sobre o caso da música em São Domingos, o diretor de banda porto-riquenho Julio Arzeno (1892-1932) $)^{40}$, em seu livro Del folk-lore musical dominicano (1927), não tinha dúvida de que o popular era contrário ao erudito e, por esse motivo, argumentou que os cantos populares dominicanos eram legítimos, "puesto que nunca ha habido un poeta culto en nuestros bosques" ${ }^{41}$. Por essa mesma época, em Cuba, chamou-se clássica a música de compositores europeus como Bach, Haydn, Mozart e Beethoven, e música popular cubana a gêneros como a canção amorosa, a música do campo, a guajira cubana, o punto, o bolero, a guaracha, a habanera, o fandango, o sapateado, a contradança, a dança, o danzón e a rumba ${ }^{42}$.

A distância entre o acadêmico e o popular também se refletiu nos trabalhos de escritores de menor notoriedade na historiografia musical, e mais próximos dos círculos musicais e populares, como o jornalista brasileiro e autor de letras de

${ }^{38}$ Galindo. Nociones de la historia de la música mejicana. p. 225.

39 Ibid., p. 344.

40 Kimball, Servicios Estudiantiles. "Efemérides dominicanas." Disponível em <http:// kimballservs.hostei.com/AnalesDominacanos.php?anatas=1932>, (28 out. 2011).

41 Arzeno, Julio. Del folk-lore musical dominicano. Santo Domingo: Imprenta "La Cuna de América" Roques Román, Hnos., 1927, p. 19.

42 "La música en Cuba (breve monografía histórica)." In: José Calero, et al. (ed.), Cuba musical. Album-resumen ilustrado de la historia y de la actual situación del arte musical en Cuba, La Habana: Imprenta de Molina, 1929, pp. 44-45. 
canções Orestes Barbosa. Em seu livro de 1933 sobre o samba, Barbosa descreveu o pianista de samba como aquele que "tem o tipo padrão de Nonô, que nunca entrou no Instituto de Música, mas perto de quem as laureadas ou os laureados que se vão exibir longe, não querem tocar" 43 . Mais adiante, Orestes Barbosa, sob a perspectiva do músico popular, assegurou que o estudo acadêmico da música escrita limitava porque os "músicos que saem do Instituto ficam em geral presos à gramática das pautas" e esclareceu: "Ninguém diz que não se estude música. Mas que se estude música do Brasil"44. Na mesma época, Mariza Lira também fez notar que Xisto da Baía (1841-1894) tinha sido um compositor de modinhas de ampla aceitação que não havia estudado música, o que, implicitamente, dava-lhe um ar de legitimidade e genialidade popular ${ }^{45}$.

De acordo com o antropólogo Rodolfo Vilhena, em seu estudo sobre os estudos de folclore no Brasil em meados do século XX, para o folclore, a oralidade foi um fator distintivo da definição de popular, mas os folcloristas não o discutiram porque se preocuparam com outros temas e não perceberam que, na realidade, esse era "o princípio da continuidade subjacente a toda a dinâmica do movimento folclórico"46. Em geral, a importância que a oralidade teve no âmbito musical é grande e tem sido pouco estudada, provavelmente por sua natureza volátil.

Como se viu, a dicotomia entre o popular e o erudito foi um dos princípios que constituíam o ambiente intelectual latino-americano, de que fizeram parte todos os autores estudados. A aparição das academias de música e conservatórios, no século XIX, radicalizou a diferença entre as tradições orais e escritas, e contribuiu para as pensar como sendo profundamente diferentes. Nos inícios do século XX, a dicotomia popular/erudito fazia parte do "oxigênio mental" que se respirava na América Latina, e do qual Mário de Andrade não pode escapar, bem como nenhum dos escritores estudados. Como eles, o musicólogo brasileiro também adotou essa dicotomia como uma realidade irredutível.

\footnotetext{
${ }^{43}$ Barbosa, Orestes. Samba: sua história, seus poetas, seus músicos e seus cantores. [1933] Rio de Janeiro: Livraria Educadora, MPB reedições Funarte, 1978, p. 99.

${ }^{44}$ Ibid., p. 107.

${ }^{45}$ Lira. Brasil sonoro. Generos e compositores populares. p. 17.

46 Vilhena. Projeto e Missão. O movimento folclórico brasileiro 1947-1964. p. 282.
} 
Tão forte foi a convicção de Mário de Andrade de que existia essa divisão entre música popular e erudita, que ele dedicou seus estudos á diminuição de sua distância, por meio do conhecimento de ambas tradições. Inclusive, a forte presença da dicotomia em seu pensamento fez com que sua escuta também se organizasse por meio desses dois "canais". Em uma curta resenha jornalística sobre o concerto da violinista Leticia Figueiro em 1933, ele explicou que a artista compunha e cantava à maneira popular, portanto, "sua arte nada tem que ver com a arte dos mestres musicais e liga-se diretamente ao cantar do povo" 47 , o que pode indicar que, também para o autor paulistano, o popular e o erudito eram claramente identificados como dois mundos à parte.

Assim como a divisão entre um mundo musical popular e outro erudito foi assumida sem maiores reflexões, também um tipo de conceito de música popular foi incorporado á linguagem, sem analises de seu significado. A maioria dos autores estudados reproduziu esse conceito mantendo sua ligação à visão de mundo romântica e, embora the tenha sido adicionada certa essência nacional, poucas vezes questionaram-se quanto à sua definição exata.

Uma exceção deu-se sob a pena do médico Miguel Galindo, que — talvez - por provir de uma disciplina acostumada a ser taxativa e a estudar sintomatologias, deteve-se sobre o significado de música popular e considerou necessário dar uma definição ao termo, em detrimento do "manto de verdade" que o romantismo tinha estendido sobre o conceito. Sua definição de 1933 manifestou a falta de precisão e condensou alguns usos do termo:

Nos parece que uno de los elementos de confusión que hay en todo esto que tratamos de explicar con la mayor claridad posible, para podernos dar a entender en lo que sigue, y muy especialmente en nuestro punto de vista del nacionalismo, es la vaga significación de la palabra popular. En efecto, esa palabra significa, en música, que ésta no es producida por autor conocido, sino que aparece como surgida de la multitud; también significa la obra anónima (si es que hay obras anónimas) y también significa la música no estudiada en las escuelas, no aprendida con ayuda de técnica alguno, sino «líricamente» según dicen los músicos que la cultivan, o como diremos nosotros, prácticamente ${ }^{48}$.

Galindo também tornou explícita a relação que o adjetivo popular guardava com o substantivo povo, e tentou esclarecer no que consistia esse "eufemismo de

\footnotetext{
${ }^{47}$ Andrade. "Letícia Figueiredo." [1933] Música e Jornalismo: Diário de S. Paulo, p. 97.

${ }^{48}$ Galindo. Nociones de la historia de la música mejicana. p. 411.
} 
moda"49. Como se verá na citação seguinte, sua definição teve uma intenção homogeneizadora, muito útil em um país como o México, onde conviviam grupos indígenas numerosos e uma representativa população mestiça:

Se llama «pueblo» etnológicamente hablando, al conjunto de individuos que, por una larga convivencia en el mismo lugar, adquieren comunidad de usos, costumbres, artes, religión y lengua, ya sea que los individuos pertenezcan a la misma raza, o a razas diferentes ${ }^{50}$.

Onze anos depois, e ao sul do continente, Carlos Vega também encarou o problema da definição de música popular. Partindo da sua experiência em trabalho de campo, somada a seus estudos sobre o tema e a um olhar suspicaz do fenômeno, ele quis dar coerência teórica a seu trabalho com a música popular argentina. Parece que, em 1944, Vega teve consciência do caráter teórico de popular, pois ao precisar que a cultura popular estava composta por sobrevivências do passado, esclareceu que essas sobrevivências "[...] sólo son supervivencias vistas desde el plano de los grupos superiores; consideradas desde el propio ambiente popular, son simples vivencias. El folklore no existe para el pueblo mismo" ${ }^{\text {. }}$.

Assim como Miguel Galindo, Carlos Vega percebeu que a compreensão do popular estaria mediada pela definição de povo, e que essa definição era tênue: “Todos sabemos qué es el pueblo, como todos sabemos qué es el arte: ... «aquello que todos saben lo que es»" 52 . "Tomando o touro pelos chifres", Carlos Vega fez a seguinte argumentação, que resume as complexidades que, já em 1944, as definições de povo enfrentavam:

La división teórica de la sociedad en clases obedece a un criterio principalmente económico. Sea el pueblo, para los economistas, la gente pobre; no para nosotros, aunque entre los grupos que nos interesan predominen los desposeídos. Con el criterio urbano, será el pueblo la gente no educada; de acuerdo, por lo menos, en que la educación popular es diferente. Para nosotros no reza el distingo, aunque la educación del pueblo sea menos artificiosa y complicada, en general. Desde el punto de vista intelectual, será el pueblo la gente menos instruida; no es esto decisivo para nosotros, pues muchos individuos intruidos pueden formar parte de nuestro pueblo folklórico en todo en cuanto no atañe a la instrucción. Para los que clasifican con criterio artístico, serán gentes del pueblo quienes cultiven arte más sencillo; pero ocurre que el pueblo de nuestra ciencia suele expedirse mediante fórmulas más complejas que las del superior, por ejemplo, en algunas especies menores de ciertas artes (poética, melódica, etc.). Con el secundario criterio de

${ }^{49}$ Ibid., p. 211.

${ }^{50}$ Ibid., p. 38.

51 Vega. Panorama de la música popular argentina. Con un ensayo sobre la ciencia del folklore. p. 26.

52 Ibid., p. 53. 
lugar, el pueblo vive en las campaña; pero muchos sujetos parcialmente folklóricos viven en las ciudades; no por cambio de ambiente, sino por tradicionalidad familiar ${ }^{53}$.

O autor disse que rechaçava todos esses critérios por considerá-los insuficientes, embora pudessem caracterizar mais ou menos o grupo humano que se escondia sob o substantivo povo. De acordo com a relevância que Carlos Vega deu às sobrevivências culturais como verdadeiro objeto do folclore, foi ao encontro de seus argumentos e propôs uma definição alternativa:

Para la ciencia del folklore, el pueblo es el conjunto de individuos que usufructúan las supervivencias [...] Los hechos no son folklóricos porque los hallemos en poder de los grupos que llamamos populares; al contrario, el pueblo que interesa al Folklore se define por la posesión de los hechos folklóricos, esto es, de las supervivencias $^{54}$.

Como se disse no capítulo anterior, Mário de Andrade teve exemplares dos livros do Carlos Vega em sua biblioteca, mas não existem alusões em seus escritos às ideias de seu colega argentino em face de suas provocadoras colocações. Não obstante, os artigos sobre a modinha de Mário de Andrade, escritos em 1941, por intermédio de sua leitura do filósofo francês Charles Lalo, são um pronunciamento a respeito da permanência de elementos musicais eruditos nas tradições populares.

De fato, em que pese a música popular ter sido um conceito central na obra musicológica de Mário de Andrade, o musicólogo brasileiro não expôs em público o significado de seu conceito. À primeira vista, a ausência da definição do conceito dá a impressão de que ele partiu de uma ideia herdeira do mundo romântico. Não obstante, por meio da leitura de seus textos musicológicos como um todo, cabe advertir que seu conceito de música popular não foi depositário do romantismo oitocentista, mas sim, que sob suas palavras escondia-se uma maneira própria de entender a dicotomia popular/erudito e o próprio conceito de música popular. O caminhar de Mário de Andrade, em zigue-zague entre o erudito e o popular, e seu afã por aproximar as duas bordas, levaram-no a pensar a música popular de um modo um pouco diferente de alguns contemporâneos seus.

\section{Mário de Andrade entre o ganzá e o piano}

\footnotetext{
${ }^{53}$ Ibid., p. 52.

${ }^{54}$ Ibid., p. 53.
} 
Apesar de Mário de Andrade ter adotado a dicotomia popular/erudito sem problematizá-la, observa-se que ele a entendeu com matizes interessantes, que vale a pena analisar. Para expor melhor essas particularidades, a dualidade popular/erudito foi recortada em seis elementos que a rodearam, e que ajudam a detalhar o que pode ter sido música popular para o musicólogo brasileiro e para seus colegas: (i) a crença de que a música popular tinha uma existência tão antiga quanto a erudita; (ii) considerações sobre as fontes de conhecimento da música popular do passado; (iii) a relação entre os adjetivos popular e nacional; (iv) a história da constituição do repertório popular; (v) o tipo de relação que se dava entre o erudito e o popular, e (vi) a inclusão de fenômenos urbanos dentro da categoria música popular.

Em primeiro lugar, sobre a idade da música popular, é notório que Mário de Andrade herdou a ideia de que esse tipo de música existiu desde o começo da história humana e de que era inata em todos os povos. Essa noção chegou por meio dos ecos do romantismo em que viveu e, ao que parece, foi tão forte que não houve nenhuma dúvida de que assim fosse, por parte dele ou de seus contemporâneos.

A antiguidade da música popular já tinha sido bem resumida por Afonso Arinos de Melo Franco em 1905, quando este afirmou que ela "existiu, em todos os tempos, até nos povos sem história, nos povos que desconhecem a escripta" 55 . Três anos depois, a mesma ideia retornou nas palavras de Guillerme Pereira de Mello, ao citar os folcloristas Barbosa Rodriguez, Coelho Netto e Mello Moraes Filho, e dizer que estava provado que "todas as collectividades humanas, mesmo as mais bárbaras, possuem uma música popular" ${ }^{56}$. Além disso, Pereira de Mello apresentou uma extensa argumentação mostrando que, no caso europeu, os compositores de maior prestígio inspiraram-se na música popular de suas regiões, porque ela "acha-se em toda parte e em todos os tempos"57. Não há dúvida de que Mário de Andrade haja conhecido o trabalho de Pereira de Mello, pois, além de possuir um exemplar entre

\footnotetext{
${ }^{55}$ Arinos, Affonso. "A música popular." Kosmos. v. 2, no. 4 (1905) p. 2.

${ }^{56}$ Mello. A música no Brasil desde os tempos coloniais até o primeiro decênio da república. $\mathrm{p}$.

${ }^{57}$ Ibid., p. 57.
} 237. 
seus livros, ele o citou em seus trabalhos sobre história musical e em sua correspondência com Renato de Almeida ${ }^{58}$.

A noção de uma música popular antiga no passado europeu aparece explícita nos livros de Mário de Andrade Compêndio de história da música (1929) e Pequena história da música (1942), nos quais menciona que essa música existiu desde a antiguidade, e explica que se sabe pouco sobre ela pela escassa documentação que foi conservada.

Na América Latina, foi imperativo ratificar a existência antiga da música popular no continente, em concordância com a noção de que toda ela devia ser um produto antigo. Assim, buscou-se fazer um contrapeso à ideia eurocentrista de que não possuíamos uma cultura popular valiosa, dada a "juventude" do continente. Em 1936, Francisco Curt Lange explicou muito bem esta crença, ao afirmar:

Toda la cultura europea, como ya he dicho oportunamente, se basa en elementos de la edad media. Aquella grande época, con su cultura popular tan intensa, representa una capa de «humus» que alimenta aun hoy a los artistas y escritores europeos. Como la América Latina carece de manifestaciones populares abundantes y homogéneas, y ante todo, de tradiciones, está sujeta hacia la tendencia de la ostentación de lo vulgar y grosero, siendo lamentable que ciertos grupos sociales se sientan inclinados hacia ello ${ }^{59}$.

No México, esteve presente o conceito de música popular como um ente que existia desde tempos imemoriais. Graças às ricas fontes documentais sobre a atividade musical colonial mexicana que sobreviveram, neste país foi possível estudar a música colonial desde datas precoces, o que facilitou a demonstração de que existia uma tradição musical um pouco mais antiga do que se acreditava comumente. Os primeiros estudos históricos mexicanos interessaram-se em procurar a música popular do período colonial e acabaram por transpor o conceito moderno de música popular para suas reconstruções do passado.

Miguel Galindo foi cuidadoso e, antes de apresentar a maneira como considerou que a música do passado mexicano dividia-se, advertiu que era "bueno

58 Ao que parece, Mário do Andrade pode ter feito uma primeira leitura desse texto antes de 1917, pois se presume que até esse ano ele fazia notas em seus livros apenas com linhas nas margens, sublinhando e escrevendo na capa os números das páginas que desejava recordar (Lopez, Telê Ancona. Mário de Andrade: ramais e caminho. São Paulo: Livraria Duas Cidades SECET, 1972, p. 23).

${ }^{59}$ Lange, Francisco Curt. "La difusión radio eléctrica como medio de educación de las masas y factor de difusión cultural e científica." Boletín Latinoamericano de Música. v. II, (1936) p. 135. 
tener en cuenta las divisiones y subdivisiones impuestas por el momento histórico de que es manifestación" "60. Galindo explicou que a música espanhola que chegou ao território mexicano dividia-se, principalmente, em sagrada e profana. À música sagrada pertenceram a música litúrgica e a música religiosa. E, ao tentar caracterizar a música profana, foi confuso e pareceu afirmar que a ela pertenceram a música popular e erudita, mas de forma consecutiva, posto que, segundo seu pensamento, "la música como la literatura, siempre se presenta primero como popular y después como erudita" 61 . É possível que o esquema de Galindo tenha ficado obscuro para ele mesmo, pois se opunha a uma das principais hipóteses de seu livro sobre a marcada influência da música eclesiástica na música popular ${ }^{62}$.

No ano seguinte, seu conterrâneo Gabriel Saldivar publicou sua História de la música en México: épocas precortesiana e colonial, na qual também deu um lugar à música popular. Em sua classificação da música colonial, observa-se que os gêneros populares contemporâneos foram tomados como subdivisões da música profana:

\begin{tabular}{|c|c|c|}
\hline \multirow{5}{*}{ Religiosa } & \multicolumn{2}{|l|}{ Motete popular } \\
\hline & \multicolumn{2}{|l|}{ Danças religiosas } \\
\hline & \multicolumn{2}{|l|}{ Pastorela } \\
\hline & \multicolumn{2}{|l|}{ Alabados } \\
\hline & \multicolumn{2}{|c|}{ Colóquios religiosos } \\
\hline \multicolumn{3}{|l|}{$\begin{array}{c}\text { Semirreligiosa } \\
\text { (de origem religiosa) }\end{array}$} \\
\hline & \multirow{3}{*}{ Acalantos } & Aborígene \\
\hline & & Mestiço \\
\hline & & Crioulo \\
\hline & \multirow{3}{*}{ Cánticas de roda } & Aborígene \\
\hline & & Mestiço \\
\hline & & Crioulo \\
\hline
\end{tabular}

${ }^{60}$ Galindo. Nociones de la historia de la música mejicana. p. 128.

61 Ibid.

62 Ibid., p. 410. 


\begin{tabular}{|c|c|c|}
\hline \multirow{8}{*}{ Profana } & \multirow{5}{*}{ Cantos de amor } & $\begin{array}{l}\text { Uma variedade do } \\
\text { corrido }\end{array}$ \\
\hline & & $\begin{array}{l}\text { Uma variedade da } \\
\text { velona }\end{array}$ \\
\hline & & A canção \\
\hline & & O son \\
\hline & & O huapango \\
\hline & \multirow{3}{*}{ Cantos diversos } & O corrido \\
\hline & & A canção \\
\hline & & O son \\
\hline
\end{tabular}

Tabela 1. Classificação da música colonial mexicana segundo Gabriel Saldivar, 1933.

Apesar das incongruências da sua classificação, parece que Saldivar compreendia por música popular, toda aquela música que não foi regulamentada pela Igreja, ultrapassando a diferença entre práticas institucionalizadas e não institucionalizadas a que nos referimos na classificação anterior.

Por outro lado, é claro que o intento de Saldivar, ao outorgar uma existência antiga aos gêneros populares nacionais, foi fruto das exigências do movimento nacionalista musical. Ao iniciar seu capítulo "Música popular", explicou a seus leitores:

El propósito de formar una serie de capítulos sobre la música popular obedece al incremento tan grande que ha tomado el estudio de sus formas en todos los países durante los últimos tiempos; responde a la necesidad creada por los altos representativos de la música mundialmente reconocidos, quienes generalmente han aprovechado las melodías populares anónimas, en muchas de sus composiciones; llegando a formarse escuelas alrededor de las tendencias del aprovechamiento de los elementos populares, con denominación de nacionalistas del país en que se desarrollan. Y como durante este tercio de siglo se ha venido luchando por un nacionalismo musical mexicano, éstos capítulos vienen a ser una reminiscencia de los albores en los cantos vernáculos ${ }^{63}$.

Em segundo lugar, e como se observa com o caso mexicano, a existência de uma música popular antiga pode ser ilustrada graças à leitura nacionalista de suas ricas e antigas fontes documentais. O caso brasileiro foi diferente. Mário do Andrade, apesar de ter adotado a crença de que a música popular sempre esteve na história

${ }^{63}$ Saldívar. Historia de la música en México: épocas precortesiana y colonial. p. 201. 
humana, não pode ignorar que não existiam fontes que sustentassem essa hipótese para o caso brasileiro, nem para muitos outros países do mundo. Como não podia ignorar esse váculo, de forma sagaz argumentou que, em geral, o pouco conhecimento da música popular do passado era causado pela escassa documentação, e, portanto, sua reconstrução era muito difícil ${ }^{64}$.

Desde jovem, Mário de Andrade pensou dessa maneira pois, em 1927, após seu retorno de sua primeira viagem ao Norte do Brasil, explicou, falando da canção popular, que “[...] o pior é que até documentação do passado falta aqui por tal forma que hoje é materialmente impossível a gente fazer um estudo de valor pratico sobre o que foi a nossa música popular e como ela evoluiu"65. Depois, em 1941, quando era um intelectual de amplo reconhecimento, em seu artigo "Evolução social da música no Brasil” fez uma rápida interpretação da história musical brasileira e nela escreveu que a música popular teve notoriedade a partir da República, quando "o povo nacional vai se delineando musicalmente" ${ }^{\prime 6}$. Parecia que, para o autor, essa notoriedade não significava que antes a música popular não existia, mas sim que, pela "escassa documentação existente" ${ }^{67}$, era difícil saber mais a seu respeito.

Esse último artigo é um dos escritos considerados centrais para se conhecer o pensamento musical de Mário de Andrade, pelos vários pontos nevrálgicos aos quais referiu-se. Entretanto, considera-se que é um escrito particularmente complexo porque nele estão condensadas as preocupações teóricas do autor, algumas sem resolução, e isso fez com que o escrito acabasse tendo um caráter de ensaio, mais do que de estudo histórico, como o seu título sugere ${ }^{68}$. Curiosamente, em carta de 1941, Mário de Andrade dizia a Renato de Almeida que, ao ler o artigo, não ficava totalmente satisfeito.

Este [texto] me inquieta e me desagrada. Sinto que enveredei por um caminho que me deu algumas visões largas e boas interpretações, mas em seu conjunto, o

\footnotetext{
${ }^{64}$ Andrade, Mário de. Pequena história da música. [1942] São Paulo: Livraria Martins Editora, 1953 , p. 60.

65 Andrade, Mário de. "Canções brasileiras I." Diario Nacional, 22 dez. 1927, p. 2. $23-24$.

66 Andrade. "Evolução social da música no Brasil." [1941] Aspectos da música brasileira, pp.

${ }^{67}$ Ibid., p. 23.

68 Particularmente para Arnaldo Contier, nesse artigo, Mário de Andrade quis, principalmente, incluir o modernismo nacionalista como o mais importante movimento estético desde o século XVI (Contier, Arnaldo D. Brasil Novo. Música, nação e modernidade: os anos 20 e 30. (Teses de livre docência) Universidade de São Paulo 1988, p. 149).
} 
trabalho (resultado em principal de ser uma conferência) me parece bastante leviano. Alem disso, quando o escrevi, não sei, estava singularmente «brillante» o que agora me desagrada. Quantas imagens...! ${ }^{69}$

Em terceiro lugar, e em relação à sinonímia criada na época entre música popular e nacional, é claro que nesse mesmo artigo de 1941 Mário de Andrade cuidou de adicionar o adjetivo brasileira a todas as manifestações de música popular às quais se referiu. $\mathrm{O}$ escritor paulistano esclareceu que, durante o período colonial, a música popular não podia ser chamada de brasileira porque "essa expressão voluntariosa de nacionalidade não interessa à Colônia"70, e evitou cair em um anacronismo do qual nem todas as histórias da música latino-americana escaparam.

Como se sabe, a chegada do nacionalismo ao âmbito latino-americano promoveu a busca de elementos culturais próprios que definissem as identidades nacionais de cada país, e se criou uma relação próxima entre os adjetivos popular e nacional. No Brasil, essa proximidade foi notoriamente sublinhada, entre outros autores, pelo mesmo Mário de Andrade, para quem:

[...] uma arte nacional já está feita na inconsciência do povo. O artista tem só que dar pros elementos já existentes uma transposição erudita que faça da música popular, música artística $[\ldots]^{71}$

Entretanto, é importante dizer que Mário de Andrade, em sua idade madura, matizou essa vizinhança entre o popular e o nacional quando esclareceu que, no passado longínquo, o popular não era nacional. Provavelmente, ele compreendeu por música popular uma música quase intrínseca às sociedades humanas - como expôs em seu Compêndio da história da música (1929). Por outro lado, possivelmente compreendeu por música nacional um fenômeno artístico de recente aparição.

No restante do continente latino-americano, observou-se que os escritores tiveram reservas em usar a expressão música popular nacional ao escrever sobre o período colonial, sob o argumento de que, durante esse período, esse tipo de música estava em formação ou tinha sido opacificada. Essas reservas não estavam relacionadas ao cuidado com o anacronismo, mas com a precaução que o nacionalismo musical teve diante do repertório colonial, período em que era evidente 317.

${ }^{69}$ Nogueira. Edição anotada da correspondência Mário de Andrade e Renato de Almeida. p. 23.

70 Andrade. "Evolução social da música no Brasil." [1941] Aspectos da música brasileira, p.

\footnotetext{
${ }^{71}$ Andrade. Ensaio sobre a música brasileira. [1928] p. 13.
} 
a ausência de traços de identidade nacional. A música colonial mostrava, a seus olhos, somente uma forte influência da música europeia nas igrejas e catedrais, e optou-se, na maioria dos casos, por minimizar sua importância e a considerar como uma época obscura ${ }^{72}$.

Contrariamente ao cuidado que Mário do Andrade teve em datar a música popular brasileira, ou melhor, a música popular nacional, depois da colônia, houve outros autores que produziram trabalhos histórico-musicais e se esforçaram por criar vínculos entre o passado e o popular. Para não ir muito longe, no Brasil há o caso de Guilherme Pereira de Mello, cujo livro diz ser, precisamente, a história do estilo característico da música popular brasileira, constituída desde o descobrimento da América, a partir da influência indígena, portuguesa, africana e espanhola ${ }^{73}$.

Em geral, optou-se — sem maiores considerações históricas — por atribuir $\mathrm{o}$ adjetivo nacional a todos os gêneros musicais populares que se pensavam antigos em seus países. Não foram raras as argumentações como a do músico argentino Arturo Schianca, que em 1933 afirmou:

[...] aun cuando un compositor argentino escriba un «yaraví», un «hayno», una «cueca», o una «polka paraguaya», de ningún modo puede ser lógicamente incluida como perteneciente a nuestro cancionero, en razón de que tal género de composiciones corresponde a otros países, y así una «cueca», escrita por ejemplo, por un argentino, será siempre un baile chileno, escrito o compuesto por un autor argentino, y nunca «cueca» argentina ${ }^{74}$.

Embora a sinonímia entre popular e nacional faça parte do oxigênio que se respirava na época, houve determinados autores que, assim como Mário de Andrade, diferenciaram os dois adjetivos. Eduardo Sánchez de Fuentes, em Cuba, Guillermo Uribe Holguín, na Colômbia, Miguel Galindo, no México, e Carlos Vega, na Argentina, fizeram colocações um pouco diferentes. Como foi mencionado no primeiro capítulo, suspeita-se que Mário do Andrade tenha lido os textos de Eduardo Sánchez de Fuentes e alguns de Carlos Vega, e é interessante ver as coincidências em seus pensamentos a respeito do conceito de música popular.

72 Contier. Brasil Novo. Música, nação e modernidade: os anos 20 e 30. p. 532, e Pérez González, Juliana. "Génesis de los estudios sobre música colonial hispanoamericana: un esbozo historiográfico." Revista Fronteras de la Historia. v. 9, (2005).

73 Mello. A música no Brasil desde os tempos coloniais até o primeiro decênio da república. pp. 5-6.

${ }^{74}$ Schianca. Historia de la música argentina. Orígen y características. pp. 159-160. 
Em Cuba, para Eduardo Sánchez de Fuentes, compositor e crítico musical a favor da origem europeia da música popular cubana, a relação entre o popular e o nacional consistia no fato de que o nacional dava "caráter" ao popular:

Convendremos en definitiva, como ya dejo dicho, que lo que determina el verdadero carácter de la música popular, no es, no puede ser en lo absoluto, ni la trivialidad ni la incorrección. Es el espíritu de la música nacional dentro de los ritmos característicos de un país ${ }^{75}$.

Mas, três anos depois, o mesmo Sánchez de Fuentes matizou sua afirmação, voltando ao assunto assim:

[...] hay que convenir en que no sólo nuestra música representativa, denominada así a la que encierra nuestro folklore, sino también la que se escribe libre de la tiranía de nuestros ritmos, es tan música cubana como cualquiera otra producida por los compositores cubanos. Por ejemplo: la canción cubana ${ }^{76}$.

Parece que, em 1928, Sánchez de Fuentes quis sair dos limites que os gêneros musicais nacionais impunham ao compositor, e tentou abrir o leque de possibilidades a uma música sem elementos populares, que não deixava de ser "cubana". No mesmo escrito, o compositor cubano continuou:

Con esto dejo dicho, queda demostrado que la música cubana no necesita prestar ritmos típicos, clasificados dentro de nuestro cancionero, para ser cubana, pues cualquiera de nuestros compositores nativos, y en cualquiera de las obras en que ponga a contribución su numen, escribirá siempre música cubana, produciendo, sin darse cuenta, con arreglo a las influencias de nuestro ambiente, y empleando en sus diseños discursos melódicos, modulaciones, cadencias, etc. y todo aquello que determina el carácter nacional de nuestra música ${ }^{77}$.

Outro compositor de formação acadêmica, voltado para a Europa e que teve uma postura similar, foi o colombiano Guillermo Uribe Holguín. Como bem anotou Egberto Bermúdez, no caso colombiano talvez ele tenha sido a única pessoa a fazer uma diferenciação pública entre música popular e música nacional em meio a um acalorado debate sobre o tema ${ }^{78}$. Em uma conferência que proferiu em 1923, Uribe Holguín denunciou que "se estabelece muito usualmente uma confusão entre o que é música nacional e música popular", e de forma pragmática, assim as diferenciou:

La primera [la música nacional] es sin duda la que pertenece a un país determinado; la que es obra de los compositores nacidos allí. Así se dice: música

${ }^{75}$ Sánchez de Fuentes. El folk-lor en la música cubana. p. 11.

${ }^{76}$ Ibid., p. 37.

${ }^{77}$ Ibid., p. 38.

78 Bermúdez, Egberto. "La Universidad Nacional y la investigación musical en Colombia: tres momentos." Miradas a la Universidad, Bogotá: Dirección Nacional de Divulgación Cultural. Universidad Nacional de Colombia, 2006. 
alemana, música francesa, etc. Puede afirmarse que no ha existido nación sin música $^{79}$.

Quanto à música popular, caracterizou-a com os adjetivos que o folclore lhe atribuía: “[...] se denomina así la que es propia del pueblo; la que le es peculiar. Música casi siempre anónima, que brota no se sabe donde y al punto es asimilada por la gran masa", como se viu no começo do capítulo ${ }^{80}$.

No México, parece que Miguel Galindo também diferenciava de algum modo a música nacional e a popular. Esse autor não fez alguma menção que mostrasse suas diferenças, sequer entrou em discussão sobre o tema. Simplesmente, quando se referiu a essas duas categorias, usou a conjunção $e$ : "música nacional $e$ música popular", como se se tratasse de duas coisas diferentes, mas próximas ${ }^{81}$. Esse matiz não levou Galindo a deixar de advogar pela importância da música popular para a constituição do repertório nacional de seu país.

Do outro lado do continente, Carlos Vega diferenciou os substantivos povo e nação em meio às suas reflexões sobre o estudo da música popular. Em 1936, iniciou seu livro sobre danças e cantos argentinos denunciando: "Desde principios del siglo hasta nuestros días, el sector música del movimiento folklórico y las escuelas nacionalistas, marchan juntos en medio de una gran confusión"82. Para o autor, parte dessa confusão residia no fato de os substantivos dos quais popular e nacional derivavam não serem diferenciados:

No hay sinonimia entre pueblo y nación. Dentro de los límites geográficos de un país pueden coexistir varios estilos, según se hayan difundido parejamente o no las invenciones procedentes de los inmediatos focos radiales; según el grado de resistencia que se haya opuesto a las importaciones ${ }^{83}$.

Em quarto lugar, continuando com os pressupostos que cercaram o conceito de música popular, vislumbra-se que, ao se pensar que a música popular existia desde tempos imemoriais e tinha uma relação estreita com a música nacional, era teoricamente prioritário fazer um trabalho que lhe outorgasse uma dimensão histórica. Embora as tentativas tenham sido muito tímidas e tenham naufragado em

79 Uribe Holguín, Guillermo. Vida de un músico colombiano. [1941] Bogotá: Fundación Editorial Epígrafe, 2010, p. 118.

80 Ibid., p. 120.

${ }^{81}$ Galindo. Nociones de la historia de la música mejicana. p. 13.

82 Vega. Danzas y canciones argentinas. Teorías e investigaciones, un ensayo sobre el tango. p.

${ }^{83}$ Ibid., p. 37. 
meio a certa confusão entre o popular e o nacional - e ainda, tendo em vista as escassas fontes documentais disponíveis - , é curioso notar que Mário de Andrade não conseguiu escapar desse artifício e tentou dar-lhe uma solução. O escritor paulistano esforçou-se para datar a constituição da música popular brasileira e, ao longo de sua vida, postulou dois momentos diferentes a partir dos quais ela teria surgido como popular e nacional.

Em 1938, para Andrade, o surgimento dessa música teria começado "mais ou menos dos meados do século dezenove para cá" ${ }^{84}$ e, em 1940, depois de viver no Rio de Janeiro e ter tido contato direto com sua música e seus intelectuais ${ }^{85}$, trocou a data para uma mais anterior: o final do século XVIII, quando "certas formas e constâncias brasileiras principiam se tradicionalizando na comunidade, como o lundu, a modinha, a sincopação"86. Talvez, como o interesse de Mário de Andrade pela música popular estava mediado pelo discurso nacionalista, seu estudo das manifestações populares musicais ocupasse-se somente da música que, como ele diz, pudesse ser chamada de brasileira. Não foi encontrado, nos textos estudados, o uso do termo música popular para caracterizar algum tipo de música do período colonial, tampouco anterior. Ao contrario, Andrade advertiu que, durante esses séculos, existiu somente música de escravos, índios e portugueses e que a música popular brasileira estava apenas em formação.

Ao que parece, Mariza Lira, admiradora do musicólogo paulistano, pensou de forma similar e considerou o período colonial como uma época de gestação do elemento popular. Em seu livro Brasil Sonoro (1938), ao se referir à modinha, a autora esboçou o argumento de que, durante o período colonial, o povo brasileiro começou a se caracterizar, e se absteve de afirmar que tivesse existido uma música popular naquele momento. Além disso, repetiu a ideia de Mário de Andrade de que a modinha era um gênero musical de herança colonial aristocrática ${ }^{87}$. Embora Mariza

${ }^{84}$ Andrade. "As bachianas." [1938] Música, doce música. Estudos da crítica e folclore, p. 273.

85 Um indicativo desse contato é seu artigo, intitulado "Ernesto Nazareth", no qual mostra entusiasmo pela conferência de Brasílio Itiberê na Associação dos Artistas Brasileiros sobre a música urbana do Rio de Janeiro. Nessa conferência, ilustrou-se a formação da música popular brasileira no século XIX, e esses argumentos podem ter levado Mário de Andrade a repensar sua hipótese (Andrade. "Ernesto Nazareth." [1940] Música, doce música. Estudos da crítica e folclore). 24.

86 Andrade. "Evolução social da música no Brasil." [1941] Aspectos da música brasileira, p.

\footnotetext{
${ }^{87}$ Lira. Brasil sonoro. Generos e compositores populares. p. 13.
} 
Lira não citasse a bibliografia que usava, talvez esses argumentos tenham partido da leitura dos trabalhos de Mário de Andrade, a quem considerou um de seus "mestres", como se viu no capítulo anterior. Em geral, Mariza Lira não se parece haver interessado particularmente em historiar os gêneros populares e, em seu livro limitou-se a introduzi-los, repetindo certos lugares-comuns sobre suas origens africanas, indígenas ou europeias. Não obstante, foi chamativa a afirmação que fez sobre a importância da obra do famoso Catulo da Paixão Cearense, a quem considerou como um dos iniciadores da música popular brasileira: “Com o Catulo começaram os primeiros ensaios para a fixação da música popular brasileira"88.

Em Cuba, houve outro intelectual que também pensou que a constituição da música popular deu-se em uma data não tão longínqua. Trata-se do autor do escrito anônimo que serve de introdução à publicação Cuba musical. Album-resumen ilustrado de la historia y de la actual situación del arte musical en Cuba, editado por José Calero e Leopoldo Valdés Quesada. Esse escrito, intitulado "La música en Cuba (Breve monografía histórica)", deu a entender que a música popular cubana havia surgido no século XIX. O autor desse escrito esclareceu:

Desde 1800 comienza a propagarse la verdadera cultura musical de este país, por la acción de maestros venidos de Europa, y de otros, nativos de Cuba, y también por el influjo de compañías artísticas procedentes de España, Italia, Francia, etc. La música, que hasta entonces, con el carácter de religiosa, había estado limitada al recinto de las iglesias, o, si era profana, no había ascendido al nivel de la canción y el baile populares, $[\ldots]^{89}$

Por outro lado, e em quinto lugar, a definição de música popular também esteve mediada pela relação atribuída entre ela e a música erudita. Mário de Andrade foi claro ao indicar que a importância da música popular, dentro dos processos históricos, residiu em oferecer elementos de inovação à música artística. Essa ideia não era própria do autor paulistano, mas circulava durante sua época em diversos rincões do mundo ocidental. Por exemplo, ela também foi exposta por outro pesquisador e músico geograficamente distante — mas próximo ideologicamente - ,

\footnotetext{
${ }^{88}$ Ibid., p. 29.

89 "La música en Cuba (breve monografía histórica)." Cuba musical. Album-resumen ilustrado de la historia y de la actual situación del arte musical en Cuba, pp. 22-23. [grifos nossos]
} 
Bela Bartok, e por diversos outros escritores através do continente latinoamericano $^{90}$.

Na ilha de Porto Rico, o músico Fernando Callejo Ferrer, em 1915, afirmou com propriedade que:

Los grandes maestros han inspirado muchos números de sus obras famosas en melodías, canciones y bailes de naturaleza regional, las que, en su mayor parte, son la expresión del sentimiento religioso o estado de la conciencia popular de la época en que se produjeron ${ }^{91}$.

Em Cuba, Eduardo Sánchez de Fuentes disse o mesmo em duas ocasiões, com as seguintes palavras:

No olvidemos un sólo momento que ella [la música popular] contribuye grandemente a la formación del alma nacional y que en ella se inspiraron los genios de la música para producir muchas de sus inmortales creaciones ${ }^{92}$.

[...] retorno a las fuentes del folkore, para encontrar en ellas las nuevas orientaciones del arte $^{93}$.

A importância de aceitar esse princípio da relação entre a música popular e a erudita está em que esta foi a base do nacionalismo musical. Graças à força que esse movimento teve em nosso continente, praticamente todos os intelectuais fizeram o convite que Julio Arzeno fez, em 1927, aos músicos e compositores de República Dominicana, resumindo assim a questão:

abandonar los ritmos exóticos y consagrarnos a ser músicos dominicanos antes que alemanes o puertorriqueños; cultivar las flores de nuestro jardín, recoger toda la fragancia silvestre y popular y derramarla en la futura música nacional; no como se ha hecho hasta ahora, la simple copia, pentagramándolo - método incipiente - en su forma primitiva, ni combinando y reuniendo los diversos temas populares para formar así un mosaico que nada añadiría al arte internacional...94

90 “...Para no remontarnos con el pensamiento a épocas demasiado lejanas y todavía poco conocidas, bastará pensar en el papel que tocara a los melodias de los corales en la música de Bach. Mientras tanto, las pastorales, las musettes de los siglo XVII y XVIII no son el en fondo sino imitaciones de la música popular de entonces, que era ejecutada en cornamusa o en citara. Finalmente, es lago muy sabido que los compositores clásicos de Viena han sufrido los llamados de la música popular: por ejemplo el tema principal de la Sinfonía partoral de Beethoven es una melodía de danza eslavo-meridional" (Bartok, Bela. "¿Qué es la música popular?" [1931] In: Roberto Raschella (ed.), Escritos sobre música popular, México: Siglo XXI, 1985, pp. 68-69).

${ }^{91}$ Callejo Ferrer. Música y músicos portorriqueños. p. 85.

92 Sánchez de Fuentes. El folk-lor en la música cubana. pp. 115-116.

${ }^{93}$ Sánchez de Fuentes. Folklorismo; artículos, notas y criticas musicales. p. 41.

${ }^{94}$ Arzeno. Del folk-lore musical dominicano. p. 16. 
Também Carlos Vega foi enfático ao dizer que essa relação não era nova, mas, ao contrário, "As tendências artísticas que aproveitam a música popular, são mais antigas que as escolas científicas de folk-lore"95.

No caso de Mário de Andrade, a relação entre música popular e erudita pode ser lida nas entrelinhas de vários de seus escritos, mas particularmente em seus dois textos sobre história da música europeia. Os livros Compêndio de história da música (1929) e Pequena história da música (1942) são uma síntese das 81 histórias da música europeia conservadas em sua biblioteca, e que ele usava para preparar suas aulas de história no Conservatório ${ }^{96}$. Esses dois livros, além de responderem a uma intenção pedagógica ao disponibilizar material em português aos estudantes ${ }^{97}$, consistem em uma reinterpretação dos fatos expostos pela historiografia europeia. Mais que uma síntese dos fatos histórico-musicais, Mário de Andrade elaborou um discurso de concatenação e organização daquele material, no qual se reflete sua interpretação dos processos históricos relatados ${ }^{98}$.

Em suas duas histórias da música europeia, o autor explicou que o papel constante que a música popular teve no passado era o de fornecer elementos musicais para alimentar a música artística:

Quando os Arnovistas se aproveitaram do espírito popular para profanizar a música, a deformação que imprimiram a êsse espírito consistiu em transportá-lo pra dentro da prática erudita, e o que era monódico no povo se tornou polifônico na arte. Quando os operistas napolitanos se aproveitaram de novo do espírito popular para regenerar a música, a deformação consistiu em aristocratizar, polir o que no povo era diamante bruto. Deram à Siciliana a forma protocolar da ária. Deram ao gôsto popular do cómico uma deformação curiosa pela qual o próprio povo é que se tornava risível ${ }^{99}$.

É notável que essa relação popular/erudito, que partiu do discurso histórico e foi assumida pelo pensamento musical da época, serviu para justificar e legitimar a 14.

95 Vega. Danzas y canciones argentinas. Teorias e investigaciones, un ensayo sobre el tango. p.

${ }^{96}$ Em sua biblioteca estão conservados 81 livros de história de música europeia.

97 Em carta dirigida a Renato de Almeida em 1925, Mário de Andrade pedia-lhe que lesse e opinasse sobre os dois primeiros capítulos de seu Compêndio de história da música, com as seguintes palavras: "Meu livro vai ser lido por mais ou menos leigos na matéria e carece de clareza. O que para mim profesional está claro, muitas vezes é obscuríssimo pros outros." Nogueira. Edição anotada da correspondência Mário de Andrade e Renato de Almeida. p. 127.

98 Seria interessante a elaboração de um estudo sobre as influências historiográficas desses livros e as interpretações que Andrade introduziu, como o surgimento e o desenvolvimento da música interessada e a música desinteressada.

${ }^{99}$ Andrade. Pequena história da música. [1942] p. 134. 
chamada do nacionalismo musical contemporâneo para a criação de repertórios nacionais, com a inclusão de elementos musicais populares.

Mário de Andrade também revisou a relação quase "natural" entre o popular e o erudito sob outra perspectiva, que o interessou enormemente até o final de sua vida. Na compilação de partituras e estudo Modinhas imperiais (1930), enfatizou que o caso desse gênero era uma exceção no papel que tinha a música popular porque, ao contrário do habitual, a modinha tinha deixado de ser música erudita, convertendo-se em música popular. Foi no ano seguinte, após escrever seu Compêndio da história da música (1929), que Andrade sublinhou, na introdução de Modinhas imperiais:

A proveniência erudita europea das Modinhas é incontestável. Por outro lado os escribas antigos, se referindo a formas populares citam o landum, o samba, o cateretê, a chiba, a fofa, etc. etc. por Brasil e Portugal, mas a Modinha de que falam é sempre a de salão, de forma e fundo eruditos, vivendo nas côrtes e na burguesia. Que eu saiba, só no sec. XIX a Modinha é referida na boca do povo do Brasil. Ora dar-se-á o caso absolutamente rarissimo duma forma erudita haver passado a popular? O contrário é que sempre se dá. Formas e processos populares em todas as épocas foram aproveitados pelos artistas eruditos e transformados de arte que se apreende em arte que se aprende. Mas formas eruditas, ver a da sinfonia, processos eruditos ver o cânone jamais que passaram prás orquestras e corais populares ${ }^{100}$.

Também no início da década de 1930, o médico mexicano Miguel Galindo, em um discurso muito menos sistemático que o de Mário de Andrade, mencionou o fato de que a música das classes altas convertera-se em música popular: "En este siglo [siglo XVIII] se usó la mazurka, la gavota y el minuet; primero en los salones cortesanos, y después en los de las clases inferiores que los imitaban"101. Tacitamente, reconheceu que esse não era um fenômeno aceito como natural e, portanto, esclareceu que:

[...] la categoría de música que se presta a la mayor confusión y la más interesante es la que siendo erudita en un principio, pasa a ser popular después, según el lugar y los ejecutantes. Pero esto no es tan accidental como parece, sino que su íntima naturaleza justifica su especial categoría. Es de tal modo adaptable al temperamento popular si viene del extranjero, que al poco de usarse ya se toma como nacional ${ }^{102}$.

Mário de Andrade retomou o estudo da modinha ao final de sua vida, nos artigos "A modinha e Lalo" e "O desnivelamento da modinha", publicados em

100 Andrade. Modinhas Imperiais. [1930] p. 8.

${ }^{101}$ Galindo. Nociones de la historia de la música mejicana. p. 343.

102 Ibid., p. 411. 
$1941^{103}$. Ali, Andrade continuou pensando no problema da popularização da música erudita por meio desse gênero, sem mudar sua hipótese inicial, e tornando explícita sua antiga ideia de que a função natural da música popular no passado tinha sido a de nutrir a música erudita. Portanto, um caso contrário, como o da modinha, era muito interessante. $\mathrm{O}$ estudo dos processos de popularização será retomado no terceiro capítulo.

Quatro anos após a publicação desses dois artigos, Carlos Vega expôs a ideia de que o objeto de estudo do folclore era a sobrevivência de elementos antigos em expressões culturais atuais e, com sua argumentação, aproximou-se do problema estudado por Mário de Andrade. Do ponto de vista do musicólogo argentino, era comum que ditas sobrevivências mantivessem-se nos grupos sociais afastados dos centros de inovação cultural e que isso se desse graças à tendência quase natural dos grupos inferiores copiar os superiores. Essa leitura do popular levou Vega a afirmar que "el tránsito directo de los pequeños bienes urbanos al ambiente rural"104 era intrínseco ao fenômeno folclórico. Vega levara mais de uma década estudando a música de seu país e gozava de prestígio como pesquisador e diretor do Instituto Nacional de Musicologia em Buenos Aires, portanto seus postulados, assim como os de Mário de Andrade no Brasil, não passaram desapercebidos por seus colegas e discípulos ${ }^{105}$.

Como, seja Mário de Andrade seja Carlos Vega sublinharam, a possibilidade de existência de trânsito do erudito para o popular era una ideia tomada da literatura sociológica e antropológica da época, e não um princípio baseado na teoria do folclore ${ }^{106}$. A arejada que o pensamento desses dois autores deu aos estudos sobre música deveu-se, justamente, à transposição de pontos de vista sobre os fenômenos populares que estavam sendo estudados por outras áreas do conhecimento. À medida em que se aproximava o fim da primeira metade do século XX, ficou claro para

103 Andrade. "A modinha e Lalo." [1941] Música, doce música. Estudos da crítica e folclore, e Andrade. "O desnivelamento da modinha." [1941] Música, doce música. Estudos da crítica e folclore.

104 Vega. Panorama de la música popular argentina. Con un ensayo sobre la ciencia del folklore. p. 35.

105 De acordo com Martha Blanche, a teoria das sobrevivências proposta por Carlos Vega teve repercussões dentro do folclore, e houve autores que adotaram sua postura (Blache, Martha. "El Concepto de Folklore en Hispanoamerica." Latin American Research Review. v. 18, no. 3 (1983)).

106 As bibliografias dos dois autores coincidem ao citar textos do filósofo francês Charles Lalo e do folclorista Arnold van Gennep para discutir suas posturas sobre esse tema. 
ambos que o folclore não oferecia as ferramentas teóricas necessárias para estudar a complexa realidade musical de seus países.

Em um meio em que imperava a ideia romântica de que o povo e o popular eram reservatórios de um passado perdido ainda não alterado pela modernidade, era difícil ver e aceitar que aquelas tradições populares não eram tão puras como se acreditava, mas sim, que eram constituídas por influências do mundo erudito ou, ainda pior, da sociedade moderna. Por esse motivo, a possibilidade de que a música popular tivesse elementos eruditos ou citadinos foi um postulado que entrou em dissonância com a mentalidade da época, e será preciso olhar pelo ângulo da indústria discográfica para se perceber que esses trânsitos eram mais frequentes do que se pensava, como se verá no terceiro capítulo.

À luz da visão de mundo romântica, música popular não foi entendida como uma categoria teórica. Nesse ambiente, seria de se esperar que ela jamais chegaria a ser considerada como um conceito de formação recente. Ao contrário, assumiu-se que era um aspecto inerente a todas as sociedades e épocas, depósito da identidade nacional, e que se devia atuar a favor de seu reconhecimento.

Mário do Andrade, particularmente, assumiu profundamente a dicotomia entre o popular e o erudito, mas sua ideia de música popular deve ser matizada em relação à ideia romântica. A respeito dessa diferença de matiz, note-se sua explicação de que a falta de fontes documentais tornava difícil o estudo da música popular antiga; ou sua observação de que, no caso brasileiro, ela constituiu-se como tal em fins do século XVIII ou início do XIX, e que nem sempre tinha sido nacional, sendo essa uma noção mais recente. Além disso, sua maneira de ver a relação entre a música popular e a erudita poderia ser esquematizada de duas formas: a música popular servindo como fonte de inspiração para a erudita e o popular tomando elementos do erudito e popularizando-os. Sua profunda convicção da existência da dicotomia popular/erudito o levou a reclamar a construção de pontes entre a música acadêmica e as artes populares, com a esperança de que a arte pudesse reconciliar a distância que crescia entre os grupos sociais.

É possível que a preocupação com a "aproximação" haja tornado-se mais profunda à medida em que o próprio ambiente musical que rodeava Mário de 
Andrade foi dividindo-se paulatinamente entre o popular e erudito. De acordo com Arnaldo Contier, desde a década de 1930, era evidente o fato de que os compositores populares vinham de grupos sociais pobres e poucas vezes interessaram-se pela aprendizagem de música erudita, enquanto que os compositores eruditos interessavam-se pela música popular urbana e folclórica para enriquecer suas composições com novos recursos. Mas, apesar dessa aproximação, a maioria dos compositores eruditos criticava a arte popular urbana, acusada de ser uma arte diretamente vinculada ao consumo, à indústria do disco e do rádio e, assim, a distância entre o popular e o erudito acentuava-se cada vez mais ${ }^{107}$.

\section{A música popular e o folclore}

Durante os últimos anos do século XIX e início do XX, um novo termo entrou no território latino-americano, nomeando uma nova "ciência" e também sendo usado para denominar um tipo de música: folk-lore (em inglês), folclore (adaptação para o português) e folclor (adaptação para o espanhol). Os estudos de folclore, fortemente imbuídos pela visão romântica de mundo, introduziram um conceito particular de música popular ou folclórica, que em pouco tempo, foi posto em xeque pela realidade musical latino-americana.

Com o transcorrer do século $\mathrm{XX}$ e a aceleração dos processos de modernização no continente, tornou-se evidente a existência de um universo musical intermediário entre o ambiente rural e a música erudita, universo que atingiu o auge nos modernos meios de comunicação eletrônicos e rapidamente ganhou um protagonismo irredutível na vida cotidiana das pessoas. Em consequência, criou-se uma distância entre a ideia do folclore, que considera a música popular como música do povo - este, entendido como um grupo afastado dos processos de modernização — , e a gama de matizes que essa noção de povo, no fundo, podia encerrar.

Nas primeiras décadas do século XX, parece que foi comum o uso do substantivo folk-lor - com a ortografia inglesa - para denominar o estudo de quem se interessava pela cultura popular, e o adjetivo folclórico como sinônimo de

\footnotetext{
${ }^{107}$ Contier. Brasil Novo. Música, nação e modernidade: os anos 20 e 30. p. 425.
} 
popular ${ }^{108}$. Tanto no âmbito lusófano quanto no hispanófono, era comum a sinonímia entre música popular e música folclórica, com algumas exceções na América Central. Ao que parece, Mário do Andrade também entendeu as palavras popular e folclórico como sinônimas, embora nem por isso seu conceito de música popular haja reduzido-se às particularidades com que o folclore a definia; ao contrário, ele incluiu outros aspectos sobre os quais o presente subcapítulo deter-se-á.

Em seu conhecido livro Ensaio sobre a música brasileira (1928), o escritor paulistano propôs-se a identificar algumas das características musicais da música popular brasileira com o objetivo de fornecer aos compositores material para trabalhar na elaboração de obras eruditas nacionais. Nesse texto, quando o autor deu ênfase à sua ideia central, as palavras popular e folclórico foram usadas como equivalentes. No início do livro, ele diz que “...uma arte nacional já está feita na inconsciência do povo. $\mathrm{O}$ artista tem só que dar pros elementos já existentes uma transposição erudita que faça da música popular, música artística..."109 e, mais adiante, quando repetiu esta ideia, trocou música popular por folclore: "O compositor brasileiro tem de se basear quer como documentação quer como inspiração no folclore" ${ }^{110}$.

Em em artigos anteriores ao Ensaio, Andrade também havia usado popular e folclórico como palavras iguais, como ficou ilustrado no artigo "Luciano Gallet. Canções brasileiras" (1927):

No Brasil o estudo da música de folclore é duma ausência vergonhosa. O pior é que até documentação do passado falta por tal forma, que hoje é materialmente

108 Em 1936, Carlos Vega mostrou que a palavra folk-lore, com sua ortografia original, era usada para se referir à disciplina que, "amanece a inicios del siglo pasado, no se preocupa al principio, de manera expresa, por la música popular. La misma voz lore no la comprende, aunque no la excluya. Son los mitos, las creencias, las supersticiones y las especies de la literatura oral, objeto inmediato, de la naciente materia. [...] Sólo al finalizar la década de 1880-1890, en que la nueva disciplina concreta sus aspiraciones, determina sus métodos y delimita su campo, aparece en su programa el propósito de coleccionar y estudiar la música, las danzas y los instrumentos del pueblo". Assim mesmo, Vega especificou que chamava usualmente de folclorista àquele que registrava e estudava crenças, costumes, superstições, lendas, refrães, adivinhações, estrofes e música popular, e até o "simples cantor dessa música" (Vega. Danzas y canciones argentinas. Teorías e investigaciones, un ensayo sobre el tango. pp. 13-15).

109 Andrade. Ensaio sobre a música brasileira. [1928] p. 16 [grifos nossos].

110 Ibid., p. 29 [grifos nossos]. 
impossível a gente fazer um estudo de valor prático sobre o que foi a nossa música popular $^{111}$.

Esta sinonímia manteve-se até o final de sua vida, pois, umas semanas antes de morrer, ele escreveu uma nota sobre algumas particularidades do popular e do popularesco - segundo seu título - e, durante toda a explicação, trocou a palavra popular por folclórico, mostrando que as continuava entendendo com portadores de significados equivalentes ${ }^{112}$.

Conforme enunciado anteriormente, no âmbito hispanófono, também foi encontrado esse mesmo tipo de sinonímia entre música popular e música folclórica, com exceção de dois escritos: um sobre a música da ilha de Porto Rico e o outro, sobre a música dominicana. Essa particularidade pode estar relacionada, em alguma medida, com um certo sentimento antiamericano das ilhas, onde era evidente a presença e intervenção dos EUA.

Em fins do século XIX, os habitantes de Porto Rico passaram do domínio espanhol ao norte-americano, como resultado da guerra hispano-americana. Justamente em 1898, ano em que o exército norte-americano invadiu a ilha, foi publicada a sua primeira história da música, de Sandalio Callejo e Ocasio ${ }^{113}$. Dezessete anos depois, o músico Fernando Callejo y Ferrer, filho de Sandalio Callejo, publicou seu livro Música y músicos puertorriqueños (1915), em cuja publicação constatou-se a ausência do anglicismo folk-lore em qualquer de suas ortografias. Talvez, como reação à presença norte-americana na ilha, Callejo y Ferrer preferiu usar as expressões em espanhol música popular e música regional como equivalentes. Esclareceu que, dentro desse "gênero popular ou regional"114, distinguiam-se dois tipos de canto: os da população camponesa e os "cantos do povo dos agrupamentos urbanos"115, como se esse popular/regional opusesse-se a outra música, de maior abrangência, que naquele momento era a música popular norte-

111 Andrade. "Luciano Gallet. Canções brasileiras." [1927] Música, doce música. Estudos da crítica e folclore, p. 171. [grifos nossos].

Aconteceu igual em seu artigo: Andrade. "Influencia portuguesa nas rodas infantis do Brasil." [1929] Música, doce música. Estudos da crítica e folclore, p. 81.

112 Andrade. "Do meu diário." [1945] Música final. Mário de Andrade e sua coluna jornalística Mundo musical, pp. 178-182.

113 Callejo y Ocasio, Sandalio. Historia de la música y los músicos. San Juan de Puerto Rico: Tip Mercantil, 1898.

114 Callejo Ferrer. Música y músicos portorriqueños. pp. 85, 231, 273.

115 Ibid., p. 276. 
americana. Compreender sob a expressão música popular seja a música do campo seja certo tipo de música urbana, foi comum nas primeiras décadas do século XX, como se estudará mais adiante.

Na República Dominicana, depois de uma história de instabilidade política e da presença norte-americana, uma década após publicar o livro de seu colega portoriquenho, o compositor Julio Arzeno tampouco parece ter considerado popular e folclórico como sinônimos. Em seu livro Del folk-lore musical dominicano (1927), ele reservou o usou das denominações: música camponesa, para a música tocada pelos habitantes do campo; música popular, para a música dos habitantes da cidade; e Folk-Lore - em sua escritura inglesa - para denominar a nova ciência que estudava "o saber popular"116. Outros autores, como o mexicano Miguel Galindo, também deram a impressão de reservar o anglicismo folk-lore para se referir àquele campo do saber. Não obstante, isto não o impediu de fazer a tradução direta de folclore para popular, tampouco o impediu de denominar indistintamente como folclórica a música popular ${ }^{117}$.

Um caso contrário ao cuidado que seus contemporâneos da América central tiveram, foi o do trabalho do músico argentino Lucas Cortijo Alahija, que publicou na década de 1910 o livro Musicologia latino-americana: la música popular y los músicos célebres de la América Latina. Ali, Cortijo intercalou os termos popular e folclórico, tomados por iguais. Mas é verdade que não se pode afirmar que a atribuição dessa equivalência tenha sido produto de alguma meditação sobre a matéria, dada a desorganização geral de seu trabalho. Esse livro foi escrito por ocasião do centenário da independência argentina, e, ao que parece, as dificuldades que ele encontrou na recopilação da informação fizeram com que, apesar do título sugestivo, seu escrito não tivesse unidade interna e fosse, no fundo, uma amálgama de diversos aspectos da atividade musical do continente, dispostos em forma de bricolage $^{118}$. A primeira parte é constituída de ensaios e conferências de outros autores, além dos próprios, e a segunda está organizada em subcapítulos que tratam

${ }^{116}$ Arzeno. Del folk-lore musical dominicano. p. 127.

117 Galindo. Nociones de la historia de la música mejicana. p. 255 y 456.

118 Em sua introdução, o autor relata que procurou buscar informação por carta e com uma viagem "como incógnito" por diversas cidades, para "analizar con libertad de acción, el desarrollo del arte en sus diferentes manifestaciones". 
de cada país. Ali, foi reimpressa parte do livro de Ramón de la Plaza, Ensayos sobre el arte en Venezuela (1883), algumas cartas recebidas e opiniões, e comentários sobre suas viagens.

Na biblioteca de Mário de Andrade há um exemplar do texto de Cortijo Alahija sem indícios de sua leitura. Outro desses exemplares chegou às mãos do mexicano Miguel Galindo, que o citou na introdução de sua história musical, criticando o fato de haver poucas notícias recolhidas pelo músico argentino a respeito do México. De acordo com Galindo, essa escassez foi uma das motivações que o levaram a escrever sua história da música mexicana ${ }^{119}$.

Por outro lado, nos escritos cubanos e mexicanos consultados, foram encontradas reiteradas referências à importância que o músico espanhol Felipe Pedrell (1841-1922), outorgou à música popular como base da música nacional. Nas citações feitas, observa-se que Pedrell também usou como equivalentes os termos folclórico e popular, e é de se imaginar que, graças ao reconhecimento que seus trabalhos obtiveram, suas colocações tenham tido eco no ambiente latino-americano, sobretudo em países como Cuba e México, onde a tradição musical espanhola era mais reconhecida. Embora no contexto brasileiro os trabalhos de Pedrell pareçam não ter sido tão mencionados, na biblioteca de Mário de Andrade, encontra-se seu livro Musicalerías: selección de artículos escogidos de crítica musical (1906), sem notas de leitura feitas por seu dono.

Em 1922, o compositor cubano Gaspar Agüero usou os termos música popular, canto popular e música folklorica como sinônimos, e por meio da menção ao musicólogo espanhol, explicou que a palavra folk-lore era um anglicismo que já havia sido aceito em outros países da Europa. Agüero especificou que essa palavra nomeava "la vida y costumbres del pueblo", para o qual a música popular "es un tesoro escondido"120. No ano seguinte, seu colega Eduardo Sanchez de Fuentes também usou como sinônimos popular,folclórico e cantos populares ${ }^{121}$.

\footnotetext{
119 Ibid., p. 10.

120 Agüero, Gaspar. Consideraciones sobre la música popular cubana: (a) sus defectos (b) sus bellezas. La Habana: Imprenta "La Propagandista", 1922, p. 6.

${ }^{121}$ Sánchez de Fuentes. El folk-lor en la música cubana.
} 
Por sua vez, na Colômbia, o termo folclore parece ter sido introduzido na década de 1910, durante as discussões sobre música nacional. Talvez, o primeiro a usá-lo haja sido Gustavo Santos, pianista, escritor e membro de uma família de reconhecido poder político. De acordo com Egberto Bermúdez:

La introducción del vocablo generó un debate limitado y superficial. [...] las escasas críticas expresadas desde los medios literarios se centran en su ortografía y su carácter de anglicismo. En 1925 por ejemplo, Enrique Otero D'Costa (1883-1964) propone reemplazarlo por el concepto de demosofía.

Ya a finales de los años veinte, el término folklore se comenzó a usar en forma generalizada como equivalente a música nacional, aunque este último vocablo seguía teniendo vigencia. Poco a poco, va sustituyendo a música nacional y luego se comienza a usar en términos amplios para designar la música de los sectores populares, campesinos e indígenas ${ }^{122}$.

No meio acadêmico colombiano, parece que, em meados do século XX, alguns escritores começaram a reservar o termo música folclórica para se referir à música camponesa e étnica, e o termo música popular para a música das cidades ${ }^{123}$. Com o transcorrer do século XX, em outros lugares da América Latina também se fez necessário ultrapassar o uso de popular e folclórico como sinônimos, advogando por sua diferenciação. Em 1941, Carlos Vega defendeu essa necessidade explicitamente para poder esclarecer em que consistia sua teoria das sobrevivências no folclore:

Todos empleamos las voces folklórico y popular como sinónimas. Pero si sólo es folklórico lo reemplazado, lo antiguo ex superior -material sugestivo y grávido para una ciencia histórica- es claro que el término popular es más comprensivo. Porque no todo lo popular es folklórico. [...]

En el ambiente popular hay, además, bienes menores que en el mismo momento pertenecen también a los grupos superiores; esto es, bienes comunes, como ciertas modas, instrumentos -tijeras, horquillas, cuchillos-, aparatos, bailes, etc. Y hallamos también en el ambiente inferior bienes propios de estratos profundos que nunca estuvieron en relación de dependencia cultural con el superior que lo estudia, como las boleadores, el poncho, etc. (lo etnográfico). Por fin entre todos esos hechos encontramos los verdaderamente folklóricos, las supervivencias, bienes que antes pertenecieron a los grupos superiores y que subsisten en el ambiente popular; y con ellas las neovivencias, productos de mezcla, evolución y recreación de los grupos inferiores. La Ciencia del folklore observa todos los bienes populares, pero aprovecha principal y especialmente las supervivencias que hablan de lo pasado al folklorista ${ }^{124}$.

122 Bermúdez. "La Universidad Nacional y la investigación musical en Colombia: tres momentos." Miradas a la Universidad, pp. 28-31.

123 Atualmente, alguns acadêmicos, como Egberto Bermúdez, têm preferido usar o termo música tradicional em vez de música folclórica para criar distância entre o seu entendimento do fenômeno e as formulações feitas pelo folclore.

124 Vega. Panorama de la música popular argentina. Con un ensayo sobre la ciencia del folklore. pp. 29-30. 
No Brasil, após a morte de Mário de Andrade e graças ao auge que, ao mesmo tempo, tiveram a música urbana e os estudos de folclore, o movimento folclórico lutou por uma definição mais precisa do que era música folclórica, discutindo-se sua analogia com popular. Conforme ilustrado pelo antropólogo Rodolfo Vilhena, essa discussão foi um dos caminhos que a Comissão Nacional de Folclore seguiu para criar um consenso a respeito do que era folclórico, de modo a definir seu objeto de estudo. De acordo com o texto Música folclórica e música popular (1958), de Renato de Almeida, parece que, nessa discussão, tornava-se insustentável continuar com a sinonímia entre música folclórica e música popular.

Renato de Almeida inicia dizendo que "o folclore é popular, mas o popular não é folclore" 125 , tratando de pôr em dúvida sua sinonímia e, talvez, retomando a visão exposta em 1944 por Carlos Vega. Assim, Almeida introduz a problemática, resume os debates em torno das definições de popular que se deram nas conferências nacionais e internacionais sobre folclore, além de enfatizar as definições apresentadas por Oneyda Alvarenga no Congresso Internacional de São Paulo em 1954. Nelas, observa-se que, como boa aluna de Mário de Andrade, Oneyda Alvarenga partiu das particularidades musicais do contexto brasileiro, propondo deixar o termo música folclórica para a música de tradição oral e o termo música popular para a música urbana ${ }^{126}$. Conforme ilustrou Rodolfo Vilhena, essas definições e, em geral a proposta brasileira sobre o que caracterizava o fato folclórico, afastavam-se das colocações europeias e causaram uma forte polêmica, que culminou em uma posterior recusa por parte dos colegas norte-americanos e europeus ${ }^{127}$.

Desde o seu surgimento na América Latina, houve várias tentativas de abrir um espaço institucional para os estudos folclóricos, e nas décadas dos anos de 1940 e

125 Almeida, Renato. "Música folclórica e música popular." Boletim da Comissão Gaúcha de Folclore. v. 22, (1958) p. 7.

${ }^{126}$ Ibid., p. 9.

127 Vilhena. Projeto e Missão. O movimento folclórico brasileiro 1947-1964. pp. 125-174. 
1950, consolidaram-se instituições dedicadas a seu estudo na maioria dos países ${ }^{128}$. Embora se haja efetivado essa promissora institucionalização, é importante ter em conta que suas noções e postulados eram conhecidos desde o início do século XX, e que suas bases no pensamento romântico fizeram com que facilmente entrasse em sintonia com o romantismo latino-americano. Como o ilustra o artigo "A música popular" (1905), de Afonso Arinos, no caso brasileiro, as ideias do filósofo alemão romântico J. G. Herder e seu conceito volklieder (canções populares) já eram bem conhecidos e valorizados nos primeiros anos do século $\mathrm{XX}$, ao ponto de Arinos definir a música popular como sendo "[...] a voz do povo em seus dias de emoção profunda; por isso a sua pátria é a terra inteira e o seu auctor é este nome universal e eterno - O homem"129.

Embora a maioria dos folcloristas adotasse, desde o começo, os princípios da nova "ciência" e compartilhassem a angústia pela perda da cultura popular em meio aos processos de modernização, houve outros autores, como Mário de Andrade e Carlos Vega, que nem sempre estiveram de acordo com todos os seus princípios, lançando algumas críticas. Inclusive, no fim da vida, Mário de Andrade tinha muito clara a relação próxima que os estudos folclóricos guardavam com o romantismo, e foi cuidadoso ao assinalar suas deficiências:

Foi o movimento intelectual do Romantismo que chamou a atenção dos escritores brasileiros para as manifestações tradicionais populares e provocou as primeiras colheitas sistemáticas de documentos. Estas colheitas, [...] foram dirigidas apenas para as manifestações da vida espiritual, canções, poesias, provérbios e ainda a lingüística, ignorando por completo a vida material e a organização social ${ }^{130}$.

Paradoxalmente, depois que os estudos do folclore alcançaram importantes níveis de institucionalização, parece que seu viés romântico os levou a entrar em crise, de modo que seus postulados não obtiveram o reconhecimento da academia latino-americana no final do século XX. Em torno do folclore, existe uma

128 Instituto de Investigaciones del Folklore Musical do Chile fundado em 1944; a Sección de Folklore y Artes populares em Perú em 1945; a Sección de Investigaciones musicales, sub-sección de Investigaciones folklóricas do México em 1946; o Instituto de Folklore de Venezuela e no Brasil a Comissão Nacional de Folclore em 1947; o Departamento de Folklore del Ministerio de Educación de Bolivia em 1954; o Centro de Estudios Folklóricos y Musicales de la Universidad Nacional de Colombia em 1959; a Campanha de defensa do folclore brasileiro (CDFB) em 1958, e o Instituto Ecuatoriano de Folklore em 1961 (Aretz, Isabel. Historia de la etnomusicologia en América Latina. Desde la época precolombina hasta nuestros días. Caracas: FUNDEC - CONAC - OEA, 1991 e Vilhena. Projeto e Missão. O movimento folclórico brasileiro 1947-1964.).

129 Arinos. "A música popular." p. 2.

${ }^{130}$ Andrade, Mário de. "O folclore no Brasil." [1949] In: Rubens Borba de Moraes, et al. (ed.), Manual Bibliográfico de Estudos Brasileiros, Rio de Janeiro: Gráfica editora Souza, 1949, p. 423. 
interessante história de fracasso quanto à sua tentativa de se posicionar enquanto uma "ciência" pois, desde o início do século XX, enfrentou um ambiente de fortes traços positivistas, no qual exigia-se um objeto de estudo concreto e reconhecido, além de um método de estudo próprio, para que dada disciplina pudesse obter tal denominação. Ademais, e em paralelo à sua luta, outras disciplinas, como a sociologia, a antropologia, a linguística e a história, lograram consolidar-se, deixando os estudos do folclore sem um campo específico no ambiente acadêmico ${ }^{131}$. Como já dizia Carlos Vega em 1944:

[...] me parece que estamos en un momento de incertidumbre con respecto a la índole y finalidad de la Ciencia del Folklore. Nada menos. Nunca fue el objeto de nuestra disciplina, formal y expresamente caracterizado. Su mismo repertorio de especies es ampliado o reducido al azar de impremeditadas ocurrencias personales. Empezó con la literatura oral, las creencias, las costumbres, y poco más; se extendió luego a todos los bienes espirituales y a los materiales; alguien propone ahora limitar su interés a las creencias y a las prácticas; en América Latina, la mayoría piensa que el Folklore se ocupa de la música y los bailes con fines artísticos. Antiguos folkloristas pretendieron invadir el campo de vecinas materias; $\mathrm{o}$, a la inversa, intentaron incluir nuestra disciplina en los dominios de ciencias afines, como la Etnografía. Modernos tratadistas quieren ahora diluir el Folklore en la Sociología ${ }^{132}$.

\section{$\underline{\mathrm{O} \text { folclore musical em Mário de Andrade }}$}

Mário do Andrade foi testemunha desse processo que o folclore viveu no ambiente latino-americano. Formou-se sob seus postulados, leu e estudou os trabalhos que os folcloristas fizeram e se baseou neles para iniciar os estudos da música popular de seu país. Mas, nesse percurso, viveu "na própria carne" o fato de que o folclore não responder a todas as perguntas levantadas por um meio musical tão complexo como o latino-americano. Embora Mário de Andrade fosse considerado folclorista por alguns de seus contemporâneos, e suas atividades de coletor de música e literatura popular o fizessem partícipe do título, sua posição diante dos estudos de folclore foi vacilante, de modo que, ao longo de sua vida, foi ficando visível a distância que o separava daquela disciplina.

131 Sobre esse processo, ver: Vilhena. Projeto e Missão. O movimento folclórico brasileiro 1947-1964. e Ortiz. Cultura popular: românticos e folcloristas.

132 Vega. Panorama de la música popular argentina. Con un ensayo sobre la ciencia del folklore. p. 20. 
Em "Romance do Veludo" (1929) ${ }^{133}$, Mário de Andrade começou fazendo sua famosa afirmação "Não sou folclorista não", frase que poderia ser lida como uma amostra de que, desde os 35 anos, o autor - com um pequeno matiz de humildade - manifestava que seu trabalho não se acomodava completamente àquilo que o folclore fazia. Durante a mesma época, ele deixou anotado em sua crônica Turista aprendiz, de 15 de dezembro de 1929:

Já afirmei que não sou folclorista. O folclore hoje é uma ciência, dizem... Me interesso pela ciência porém não tenho capacidade para ser cientista. Minha intenção é fornecer documentação para músico e não, passar vinte anos escrevendo três volumes sobre a expressão fisionômica do lagarto.... 134

Uns anos depois, quando Mário de Andrade estudou uma expressão do samba em São Paulo, à luz das lições ministradas por Dina Lévi-Strauss, aceitou que:

por infelicidade minha, sempre me quis considerar amador em folclore. Disso derivara serem muito incompletas as minhas observações tomadas até agora. $\mathrm{O}$ fato de me ter dedicado a colheitas e estudos folclóricos não derivou nunca duma preocupação científica que eu julgava superior às minhas forças, tempo disponível e outras preocupações. Com as minhas colheitas e estudos mais ou menos amadoristicos, só tive em mira conhecer com intimidade a minha gente e proporcionar a poetas e músicos, documentação popular mais farta. Hoje, que os estudos folclóricos se desenvolveram bastante em São Paulo, me arrependo raivosamente da falsa covardia que enfraquece tanto a documentação que recolhi pelo Brasil, mas é tarde ${ }^{135}$.

Mário de Andrade fez essa declaração em 1937, em um momento de efervescência intelectual em São Paulo quando, três anos antes, fora fundada a Universidade de São Paulo e, um ano depois, chegara a chamada "missão francesa", formada por intelectuais como o geógrafo Pierre Monbeig, o sociólogo Paul Arbousse-Bastide, o historiador Fernand Braudel e os filósofos Jean Maugüe, Claude Lévi-Strauss e Dina Dreyfus Lévi-Strauss.

Como narra Luisa Valentini, com a chegada do grupo francês ao Brasil, Dina Lévi-Strauss ficou sem trabalho formal porque, tanto a Universidade de São Paulo quanto o Liceu Franco-Brasileiro, para os quais estava destinada, não se interessaram em contratar a jovem professora. Diante dessa situação, Dina D. LéviStrauss aceitou o convite de Mário de Andrade para ministrar um curso de etnografia

133 Andrade. "O romance do Veludo." [1928] Música, doce música. Estudos da crítica e folclore, pp. 67-73.

134 Publicada originalmente em sua coluna "O Turista Aprendiz" do Diário Nacional e depois em: Andrade. O turista aprendiz. [1928-9] p. 232.

135 Andrade. "O samba rural paulista." [1937] Aspectos da música brasileira, pp. 112-113. 
no Departamento de Cultura que ele dirigia. Em contrapartida, Dina contou com o apoio de Mário de Andrade para a realização da expedição para conhecer os indígenas Kadiwéu e Bororo em Mato Grosso, no final de 1935, assim como para sua viagem à Serra do Norte, em 1938. Ambas as excursões, feitas junto com seu marido, Claude Lévi-Strauss, e com o apoio financeiro do Departamento de Cultura de São Paulo ${ }^{136}$.

Dessa associação entre os jovens franceses e Mário de Andrade, surgiu um rico intercâmbio acadêmico que se formalizou sob o marco do curso de Etnografia mencionado, e na fundação e decorrentes atividades da Sociedade da Etnografia e Folclore. Dessas atividades, também participaram figuras como Oneyda Alvarenga e Rossini Tavares de Lima, que terão um peso importante nas futuras discussões sobre o objeto do folclore.

Em meio a essa experiência, Mário de Andrade aproximou-se do que começava a se consolidar como os estudos antropológicos e etnográficos, com os quais matizou suas ideias sobre cultura popular e enriqueceu suas ferramentas intelectuais para seu estudo de música. Durante esses anos, a diferença entre o folclore e a antropologia era embrionária, e, por exemplo, no mesmo curso sobre etnografia, o folclore foi incluído como um dos temas a serem tratados ${ }^{137}$. Não obstante, observa-se no trabalho de Mário de Andrade, uma mudança que incide sobre a escolha de dos métodos de trabalho de campo, advindos da etnografia - os quais pôs em prática em seu artigo "O samba rural paulista" (1937) — e sobre a radicalização de uma posição cada vez mais crítica em relação ao folclore enquanto disciplina.

No início da década de 1940, Mário de Andrade conhecia a definição clássica do que era considerado folclórico, mas sua opinião sobre o tema só seria conhecida em 1949 - quatro anos depois de sua morte —, quando foi publicado o livro Manual bibliográfico de estudos brasileiros, no qual ele encarregou-se do capítulo sobre folclore.

\footnotetext{
136 Valentini, Luisa. Um laboratório de antropologia: o encontro entre Mário de Andrade, Dina Dreyfus e Claude Lévi-Strauss (1935-1938). (Dissertação) Universidade de São Paulo, 2010.

137 Ibid., pp. 18, 34.
} 
Graças ao uso que, em 1941, Mário do Andrade fez da caracterização que o folclore fazia da coisa popular, pode-se antever que o autor paulistano conhecia muito bem a postura clássica a respeito. Em um de seus artigos sobre a modinha, ele esclareceu que não a considerava como "valor folclórico" porque sabia que era urbana, sendo algumas, inclusive, de autor conhecido; além disso a modinha não era inculta ou ágrafa, tampouco se havia tradicionalizado no inconsciente do povo para se estabelecer como tradição ${ }^{138}$. Graças a essa negação da modinha como coisa folclórica, acredita-se que, para Mário de Andrade, as condições para decidir se algo era ou não folclórico resumiam-se em ser rural, anônimo, inculto, ágrafo, tradicional e do povo. De forma mais esquemática, nosso autor definiu o folclórico, como uma expressão do povo analfabeto e tradicional pela boca do compositor Janjão, um de seus personagens de $O$ banquete $(1943)^{139}$.

Mário do Andrade teve em comum com o folclore seu interesse pela recopilação das obras de tradições orais. Assim como os folcloristas, o escritor paulistano dedicou tempo de sua vida à anotação e organização das manifestações da cultura popular que o rodeavam, não só música, mas também na literatura e na cultura material. No início de sua vida como pesquisador, conheceu a música popular brasileira por meio de um sistemático trabalho de gabinete baseado na compilação de material relativo è música popular, obtido por meio de cartas; também reuniu as notícias sobre música fornecidas pelos livros de viajantes dos séculos XVIII e XIX; empenhou-se na análise das partituras que chegavam às suas mãos, e formou uma coleção de discos de $78 \mathrm{rpm}$, que ouviu com atenção.

Talvez, depois de suas viagens, de 1927 e 1929, ao Amazonas e ao Nordeste, e de após se ter deparado com as dificuldades do trabalho de campo, Mário de Andrade tenha percebido a existência de problemas que transcorriam entre a recopilação da música popular e sua base teórica advinda das pesquisas folcloristas. Ocorreu que o folclore não oferecia ferramentas práticas ou, mesmo, não considerava todas as complexidades da música popular em suas investidas. Entre essas dificuldades, estava a ineficiência do sistema de notação musical europeu, que não

138 Andrade. "O desnivelamento da modinha." [1941] Música, doce música. Estudos da crítica e folclore, p. 344 .

${ }^{139}$ Andrade. O banquete. [1943] p. 61. 
tinha todos os recursos que a transcrição musical exigia, particularmente a notação rítmica, e terminava por interditar o registro do fenômeno musical. Essa dificuldade foi enunciada em seu Ensaio sobre a música brasileira (1928), em quê, ao se referir à música de Sinhô, ele sublinhou que essa música, no papel e no cenário, eram diferentes por conta da imprecisão do sistema de escritura musical.

Os maxixes impressos de Sinhô são no geral banalidades melódicas. Executados, são peças soberbas, a melodia se transfigurando ao ritmo novo ${ }^{140}$.

Em suas viagens, também teve contato com as realidades das províncias brasileiras e com a grande quantidade de matizes humanos e artísticos que o folclore desconhecia, como, por exemplo, a não pureza do idílico "povo", expresso em forma de conto em "Briga das pastoras" (escrito em 1939)141. Provavelmente, essas experiências em campo e sua própria formação como pesquisador, levaram-no a ter a firme convicção de que, para conhecer a cultura popular brasileira, era prioritário sair do gabinete e desenvolver o trabalho etnográfico. Essa convicção materializou-se em sua gestão no Departamento de Cultura, à frente da Missão de Pesquisa Folclórica, que, armada com a tecnologia da época, saiu recolhendo material folclórico ou popular brasileiro.

Como é sabido, no Brasil, a Missão de Pesquisa Folclórica foi uma das mais importantes recopilações de música popular em registros sonoros e imagens. Embora as mudanças administrativas a tenham levado a um final intempestivo, seu planejamento e seis meses de trabalho podem oferecer indícios sobre o conceito de música popular no qual ela baseou-se, o qual precisaria ser alimentado pela ampla documentação que produziu, cuja investigação implicaria um estudo à parte.

Por ora, só se pode assinalar que, em princípio, a Missão de Pesquisa Folclórica não se diferenciou de outras iniciativas latino-americanas do século XX, ao sair a campo para registrar com aparelhos de gravação as manifestações musicais populares. Esse tipo de projeto foi concebido sobre os esboços do folclore e respaldado pelo nacionalismo, para "salvar" a cultura popular, mumificando-a em museus e discos. Nessas excursões imperou o conceito de música popular, como

\footnotetext{
${ }^{140}$ Andrade. Ensaio sobre a música brasileira. [1928] p. 23.

${ }^{141}$ Andrade, Mario de. Obra imatura. [1960] Rio de Janeiro: Agir, 2009.
} 
música valiosa por si mesma, anônima, tradicional e oral, conforme os folcloristas ensinavam.

De acordo com Flávia Camargo Toni, o projeto inicial da Missão de Pesquisa Folclórica visava a volta às mesmas regiões a cada cinco anos para tomar novas amostras e juntar material que permitisse estudar as mudanças que se operavam $^{142}$. Embora o projeto não tenha sido aprovado, essa intenção partia de uma concepção de música popular um pouco diferente daquela proposta pelo folclore, posto que considerava a mudança como uma aresta de estudo e não como um mal. Talvez, a não aprovação da proposta seja sintoma de que o conceito de música popular imperante era aquele proposto pelo folclore. Em segundo lugar, parece que a recomendação geral dada a Luis Saia, Martín Braunwieser, Benedicto Pacheco e Antônio Ladeira quando saíram de São Paulo foi a de registrar "as músicas que homens, mulheres e crianças cantavam para trabalhar, divertir-se e rezar" ${ }^{\prime 43}$, ou seja, uma definição baseada nos parâmetros de utilidade com os quais Mário de Andrade caracterizou a arte popular, sobre os quais voltar-se-á no final do capítulo.

Independentemente das diferenças que pudessem existir entre os conceitos de música popular do musicólogo brasileiro e do folclore, o certo é que a Missão foi pensada e aplaudida partindo-se do conceito folclórico de música popular e do projeto nacionalista brasileiro, o qual fez com que os participantes, ou aqueles que manipularam o material compilado, tivessem uma maneira particular de ouvir e pensar seus registros ${ }^{144}$.

Por outro lado, a curiosidade intelectual e o caráter autodidata de Mário de Andrade levaram-no a temas e materiais que o folclore não contemplava, como é o caso de certas expressões de música urbana ou da relação fisiológica do ritmo com o indivíduo, entre outros. Se Mário de Andrade estudou a música popular passando do gabinete ao trabalho de campo, talvez, no início, tenha recebido os ensinamentos da disciplina do folclore com certo respeito. Mas, à medida que conheceu as complexidades advindas de sua experiência em campo, sentiu que essa disciplina não

\footnotetext{
142 Toni, Flávia Camargo, Missão: as pesquisas folclóricas [Sao Paulo]: Sesc; Centro Cultural São Paulo; Secretaria de Cultura, Prefeitura de São Paulo, 2007.

143 Ibid., pp. 78-79.

144 Ver: Moraes, José Geraldo Vinci de. "E «Se você jurar», «Pelo telefone», que estou na Missão de Pesquisas Folclóricas?" Revista USP. v. 87, (2010).
} 
lhe oferecia as ferramentas de que necessitava, enquanto que outras disciplinas, como a antropologia e a sociologia, tinham um olhar mais amplo. Por essa razão, as inquietações acadêmicas de Mário de Andrade encontravam nestas disciplinas um espaço mais cômodo para se desenvolver ${ }^{145}$.

Dentre as diferenças entre o trabalho de Mário de Andrade e o folclore, sobressaem-se aspectos como o aspecto utilitário que o escritor brasileiro deu às expressões populares em sua obra literária, pois, como é sabido, longe de uma atitude museológica, nosso autor apropriou-se delas e as converteu em matéria-prima de sua obra $^{146}$. Além disso, teve a firme convicção de que também os músicos deviam usar a música popular para construir o repertório erudito brasileiro, como indicava o nacionalismo imperante.

Ademais, em que pese o fato de folclore e nacionalismo caminharem de mãos dadas, parece que Mário de Andrade tinha uma opinião ligeiramente diferente sobre este princípio. No artigo "Origens do fado" (1930), em que o autor apresentou provas de que esse gênero tinha nascido no Brasil, e não em Portugal como se acreditava, defendeu que "o que realiza, justifica e define uma criação nacional folclórica é a sua adaptação pelo povo"147 e não o lugar onde ela nasceu. Em consequência, e pensando dessa maneira, o musicólogo não teve problema em aceitar que o fado tinha nascido no Brasil e que isso não o impedia de ser uma das formas portuguesas nacionais. Embora essa mesma ideia não seja encontrada em trabalhos posteriores, ela é interessante porque contradiz o caráter nacionalista que incentivou os estudos de folclore na primeira metade do século XX.

Seis anos depois, Carlos Vega também criticou, a partir de outro ponto de vista, a posição nacionalista que o folclore tomava:

Si lo nuestro es lo mismo de los otros, no dejará por eso de pertenecernos. Buena parte de los bienes de América española fueron o son de varias naciones por identidad de origen y por intercambio posterior. No podrá oscurecerse la conciencia

145 Para conhecer algumas das ferramentas da etnografia aprendida por nosso autor, ver: LeviStrauss, Dina. Instruções práticas para pesquisas de antropologia física e cultural. São Paulo: Departamento de cultura. Prefeitura de São Paulo, 1936.

146 Mello e Souza. O tupi e o alaúde.

147 Andrade. "Origens do fado." [1930] Música, doce música. Estudos da crítica e folclore, p. 95. 
de propiedad, aunque la investigación, contrariando ingenuos anhelos, destruya la ilusión de las creaciones absolutas y rompa el encanto de la posesión exclusiva ${ }^{148}$.

Por outro lado, em 1945, pouco antes de morrer, Mário de Andrade fez outra declaração contrária às concepções do folclore, desta vez sobre a imutabilidade do fenômeno folclórico, quando defendeu a admissão da natureza mutável do tradicional, ao menos no caso latino-americano. Afirmou que,

o objeto folclórico é que merece o museu, merece ser guardado com o maior carinho, e apresentado sempre ao público urbanizado. No entanto êle é antimuseológico por natureza, vai se transformando com o tempo em mil variantes $^{149}$.

Dessa maneira, Mário de Andrade deixa ver que fixar ou sujeitar uma tradição folclórica significa tirá-la de seu contexto, indo contra a sua natureza, porque ela seria intrinsecamente mutável. Isso significava contradizer uma das principais bases dos estudos folclóricos, segundo a qual as transformações da tradição eram consequências deploráveis dos processos de modernização, e não uma característica de sua essência. Sua ideia sobre a mutabilidade do folclore talvez tenha ecoado entre seus alunos, e pode ter influenciado, em alguma medida, o surgimento da ideia de "folclore nascente", presente nas discussões que, na década de 1950, os folcloristas provocaram ao declarar que o fenômeno folclórico poderia possuir uma formação recente ${ }^{150}$.

Outro indício da distância que Mário de Andrade identificou, no fim da vida, entre seus trabalhos e os do folclore foi o uso, com cada vez maior frequência, da palavra "folcloristas" escrita entre aspas e do termo "folclorismo". Com esta última, parece ter querido denotar um tipo de deformação dos estudos de folclore, provavelmente os mais dogmáticos e intransigentes pois, na sua opinião, era preciso "alargar a conceituação científica do folclore" ${ }^{151}$, coisa que ele tinha consciência de ter ajudado a fazer em seus trabalhos.

No escrito "O folclore no Brasil" (1949), o autor começou afirmando que a situação dos estudos de folclore não era boa, que o folclore "ainda não é p. 26.

148 Vega. Danzas y canciones argentinas. Teorias e investigaciones, un ensayo sobre el tango.

\footnotetext{
${ }^{149}$ Andrade. "Do meu diário." [1945] Música final. Mário de Andrade e sua coluna jornalística Mundo musical, p. 179.

${ }^{150}$ Vilhena. Projeto e Missão. O movimento folclórico brasileiro 1947-1964. p. 141.

${ }^{151}$ Andrade. "Cândido Inácio da Silva e o lundu." [1945] p. 218.
} 
verdadeiramente concebido como um processo de conhecimento", e criticou os “cantadores de rádio, disco e mesmo conserto, [que] se intitularem «folcloristas» só porque usam e abusam da canção popular"152. Também deixou dito que “[...] o conceito de folclore e a sua definição, tais como nos vieram fixados pela ciência europeia, têm de ser alargados para se adaptarem aos países americanos"153.

Fora do território brasileiro, na América hispânica houve um exército de pessoas que se identificaram com as premissas dos estudos de folclore. A maioria de seus trabalhos tiveram um caráter amador, e sua produção ficou relegada como "pouco confiável” pelos acadêmicos que aproximaram-se dela. Há que se dizer que essa prevenção fez com que, até há poucos anos, iniciassem-se estudos sobre o significado do movimento folclórico latino-americano em seu contexto, e que graças a essas aproximações percebe-se que, no mesmo movimento folclórico latinoamericano, houve matizes e que os postulados forjados na Europa e nos Estados Unidos nem sempre encontraram aceitação ${ }^{154}$.

Um dos pesquisadores de maior notoriedade na América hispana foi Carlos Vega e, embora fosse considerado folclorista por seus contemporâneos, ele também discordou em alguns pontos do folclore tradicional. Casualmente, essas críticas foram consignadas nos trabalhos que publicou e enviou a Mário de Andrade em São Paulo.

Sem aprofundar seu pensamento, chama a atenção o fato de que, desde a década de 1930, Carlos Vega considerasse que a musicologia era mais apropriada que o folclore para o estudo da música na América Latina. Segundo ele, a musicologia perfilava-se como ciência; estudava tanto as manifestações musicais indígenas quanto mestiças e "los núcleos populares contemporáneos"; ademais, não escolhia seu material por meio de parâmetros estéticos, mas "es tan indiferente a la belleza

152 Andrade. "O folclore no Brasil." [1949] Manual Bibliográfico de Estudos Brasileiros, p. 422.

153 Ibid., p. 441.

154 Ver os trabalhos da folclorista Martha Blache e dos antropólogos Carlos Miñana e Rodolfo Vilhena: Blache. "El Concepto de Folklore en Hispanoamerica."; Miñana Blasco, Carlos. "Entre el folklore y la etnomusicología. 60 años de estudios sobre la música popular tradicional en Colombia." A contratiempo. Revista de música en la cultura. v. 11, (2000), e Vilhena. Projeto e Missão. O movimento folclórico brasileiro 1947-1964.) 
como a la fealdad"; não servia ao nacionalismo musical e, portanto, não the importavam as possibilidades artísticas de um canto e nem que:

[...] en el caso de nuestro país, que esto o aquello no sea argentino; si no es argentino, no hará el musicólogo esfuerzos dialécticos por que lo sea. El patriotismo, en musicología, consiste en trabajar honradamente, camino de la verdad $^{155}$.

Nessa mesma época, Carlos Vega criticou a prática, comum entre os colecionadores de música ou literatura popular, de "corrigir" ou modificar algumas de suas expressões. Tanto Carlos Vega quanto Mário de Andrade distinguiram o trabalho de quem recolhia informação e de quem a recolhia e transformava, pois, referindo-se ao trabalho do compositor Luciano Gallet, o autor paulistano observou que as canções populares que o músico carioca havia publicado em 1927 não eram expressões totalmente populares, posto que o músico havia harmonizado as melodias. Isso não tirava o valor do seu trabalho, mas simplesmente alterava seu caráter ${ }^{156}$. Em 1936, Carlos Vega, por sua vez, disse:

Cuando los artistas se dedican a la recolección de melodías populares, el pensamiento folklórico adquiere un principio de realización; pero cuando esos mismo colectores adornan, si no modifican, sus materiales con artificios armónicos propios de las tendencias cultas dominantes, o recomponen libremente sobre los temas populares, el impulso inicial se desvía hacia las escuelas nacionalistas, pierde la página su valor documental y no se cumple el objetivo de la disciplina folklórica ${ }^{157}$.

Por outro lado, no mar do Caribe, o músico Julio Arzeno parecia estar longe do sentimento inerente aos estudos folclóricos oitocentistas de viver sob a nostalgia de um passado em perigo de extinção. Pelo contrário, esse autor, quando se referiu a algumas canções que não eram cantadas em seu país, disse:

no cabe duda, que en materia de cantares en aquellas épocas idas, eran de mejor gusto y más poéticos que los que ahora oímos. No somos ni queremos ser anacrónicos, pero es lástima que nuestras típicas costumbres y fiestas populares se vayan olvidando, disque, como «cosas de los viejos».

Cada época tiene su espíritu, o mejor cada espíritu tiene su época y cada generación sus gustos y aficiones y no repetiremos con el poeta «O, tiempos que

155 Andrade, Mário de. "Dançãs dramáticas iberobrasileiras." Música do Brasil, Curitiba: Guaira, 1941, pp. 16-17.

156 "Me lembro que ele afirma fazer obra simplesmente de registrador de folclore. Isso não é verdade e creio mesmo que Luciano Gallet é artista por demais para se sujeitar a esse trabalho etnográfico" (Andrade. "Luciano Gallet. Canções brasileiras." [1927] Música, doce música. Estudos da crítica e folclore, p. 172.) p. 14.

157 Vega. Danzas y canciones argentinas. Teorías e investigaciones, un ensayo sobre el tango. 
fueron y no volverán, tiempos que huyeron y jamás serán» sino que amamos las cosas del ambiente y de nuestra época ${ }^{158}$.

Mais adiante, Arzeno mostrou-se a favor de arquivar os cantos abandonados para "conservar memória" e não para "poner en actualidad lo que ya calló en desuso" $" 159$.

Carlos Vega também observou com incredulidade a leitura fatalista e romântica do folclore, que culpava a modernidade pela destruição da cultura popular. Em 1944, disse com certo sarcasmo:

Vieja es la idea de antiguedad en la ciencia del Folklore; [...] Para los folcloristas, el patrimonio popular era una masa eterna; estaba quieta en los dominios del pueblo desde muchísimos siglos atrás. Cada uno, a partir de Thoms, observó, sin embargo, que las cosas populares empezaban a desaparecer. Todos dieron en la misma idea a lo largo de cien años; siempre lo popular estaba empezando a desaparecer. Y todos atribuyeron a su propio tiempo un especial poder destructor desconocido antes. Según eso, poco o nada debió quedar en el terreno folklórico; y no ocurre tal $\operatorname{cosa}^{160}$.

Em resumo, pode-se notar que, embora durante a primeira metade do século XX muitos autores usassem os termos música popular e música folclórica como sinônimos ou equivalentes, nem por isso todos teriam adotado o conceito que o folclore propunha. No caso de Mário de Andrade, tudo indica que, no fim da vida, ele foi crítico em relação ao folclore como ciência e que teria encontrado em outras disciplinas - como a etnografia - melhores ferramentas de trabalho. Tanto Carlos Vega quanto Mário de Andrade desconfiaram da influência que o romantismo exercia sobre o folclore e, embora não se tenham divorciado completamente dele, manifestaram-se em desacordo e mudaram seus próprios conceitos de música popular para acomodá-los a seus ambientes.

Da postura não alinhada do escritor brasileiro com o conceito de música popular do folclore, destacaram-se divergências como a diferenciação entre fazer recopilações musicais para analisá-las e para usar dentro de obras de criação artística. Também houve alguma desconfiança relativa à relação quase inerente que o folclore propunha entre popular e nacional, embora não pareça ter sido marcante. E, do mesmo modo, reconheceu-se que havia transformações naturais na música popular em lugar de um princípio de imutabilidade. Essas foram algumas diferenças sutis

158 Arzeno. Del folk-lore musical dominicano. p. 84.

159 Ibid., p. 127.

160 Vega. Panorama de la música popular argentina. Con un ensayo sobre la ciencia del folklore. p. 30 . 
entre o pensamento musical de Mário de Andrade e as noções do folclore; entretanto, parece que o lugar dado à música das cidades foi a diferença mais visível entre eles, como se ilustrará a seguir.

\section{As cidades e a música popular}

Talvez, a inclusão de algumas expressões musicais urbanas fosse uma das maiores diferenças que o conceito de música popular de Mário de Andrade e de alguns de seus contemporâneos latino-americanos encerrava. O uso amplo do conceito possivelmente esteve mediado pelo grau de modernização que tiveram as cidades onde viveram os autores, dentre outros fatores.

Nos casos dos autores de São Paulo, México D.C. e Havana, onde as culturas urbanas musicais consolidaram-se com maior rapidez, houve quem não tivesse como desconhecer esse fenômeno, optando por incluí-lo — em alguma medida - dentro do que chamavam música popular. Outros autores tomaram certo cuidado com os novos fenômenos musicais e os deixaram fora de seu trabalho, ou só os mencionaram para "lançar alguns dardos" contra. Em muitos casos, a perspectiva de mundo romântica acabou por convencer os escritores de que a música popular urbana era um mal de seu tempo, e que sua presença atrapalhava o movimento de nacionalização da música popular rural.

Ainda que, tradicionalmente, enfatize-se que o romantismo exalta a figura individual, Michael Löwy e Robert Sayre argumentaram que esse sujeito individual de que o romantismo tinha saudades, tinha sentido em sua função, como parte de uma unidade, e que essa unidade relacionava-se com a natureza e com a coletividade humana. Como consequência, "a exigência de comunidade é tão essencial para a definição da visão romântica, quanto seu aspecto subjetivo e individual"161. Parece que um dos melhores lugares em que ficou claro ao romantismo que essa unidade não se havia perdido foi na noção de povo, entendido como um grupo humano primordialmente rural.

Como bem resumiu Renato Ortiz, o folclore definiu o povo implicitamente como um grupo homogêneo, com hábitos mentais similares, em que — acrescente-se

${ }^{161}$ Löwy e Sayre. Revolta e melancolia. O romantismo na contramão da modernidade. p. 46. 
— os laços sociais não se haviam quebrado. Como o mesmo Ortiz apontou, essa noção era uma categoria teórica que não correspondia a uma realidade claramente definida, pois se privilegiou o homem do campo não em sua função social, mas como o mais isolado da civilização, e essa postura fez com que alguns pontos intermediários ficassem fora de seu foco:

[...] Movimentos de imigração para a cidade, formas de produção, inserção do camponês na sociedade nacional, são esses os temas ausentes, tabus; eles escapam à própria definição do que seria popular ${ }^{162}$.

Esse "tabu", que ignorava um grupo de camponeses que pudesse haver mantidor algum tipo de relação com a modernidade, é uma das heranças deixadas pelos estudos de folclore europeus no conceito de música popular dos intelectuais mais dogmáticos. Não obstante, essa definição encontrou, na América Latina, realidades mais complexas que, às vezes, impediram sua imediata adoção, levando alguns escritores à reflexão.

Como é sabido, essa prevenção diante do urbano foi tirada das colocações de J. G. Herder, que falou sobre uma separação entre o povo e a classe operária, que não fazia parte deste, mas vivia em um nível de barbárie nas indústrias e ruas das cidades $^{163}$. Tudo parece indicar que essa separação campo/cidade é um reflexo da crítica à modernidade e ao sistema capitalista, cujo coração encontrava-se precisamente nas cidades industrializadas, onde se consolidou uma classe social trabalhadora de ascendência rural. Esse rechaço fez com que em muitas ocasiões deixasse-se os fenômenos urbanos de fora dos estudos de folclore. Não obstante, na América Latina, a convivência de sistemas capitalistas e pré-capitalistas durante o século XIX, e até no XX, fez com que, em algumas ocasiões, ampliasse-se o conceito de música popular para incluir elementos do mundo urbano.

Portanto, embora muitos autores latino-americanos, como Mário de Andrade, tenham igualado o popular ao folclórico, esse popular-folclórico não se restringia às tradições orais camponesas. Por exemplo, no Ensaio sobre a música

162 Ortiz. Cultura popular: românticos e folcloristas. p. 25.

163 "Herder escreveu que «o povo não é a turba das ruas, que nunca canta nem compõe, mas grita e mutila»" (Burke. Cultura popular na idade moderna. [1978] p. 48). Para Edward Taylor, autor do livro Cultura primitiva (1871), que também influenciou os folcloristas, "em nossas grandes cidades, as chamadas classes perigosas estão afundadas numa miséria horrenda e na depravação. [...] temos que conceder que possuímos em nosso meio algo pior do que a selvageria. Mas isto não é selvageria, é civilização decadente" (apud. Ortiz. Cultura popular: românticos e folcloristas. p. 38). 
brasileira (1928), o autor incluiu partituras de música popular de gêneros de origem urbana como o maxixe, o samba, a embolada e o cateretê. Note-se que, a principio, seu meio de circulação (a partitura), faria com que o folclore tradicional os deixasse fora de seu círculo de interesses ${ }^{164}$.

A inclusão de alguma música escrita dentro da categoria música popular ou folclórica também foi feita por seu colega cubano Eduardo Sánchez de Fuentes. Em seu livro El Folk-lore en la música cubana (1923), exemplar lido e anotado por Mário de Andrade, Sanchez de Fuentes fez todas as suas observações sobre as características musicais da música cubana, baseado em partituras de gêneros como o danzón, a contradança, a habanera, a clave, a crioula, etc. ${ }^{165}$.

Por outro lado, a inclusão do urbano também foi feita por meio do estudo de alguns gêneros musicais que se desenvolviam nas cidades. Durante os primeiros anos, Mário de Andrade valorizou particularmente o maxixe e, além de lhe dar atenção em seu Ensaio sobre a música brasileira (1928), dois anos antes o havia qualificado como "dança urbana genuinamente brasileira"166; adicionalmente, ao revisar as notas que deixou, cujo destino era o de compor seu Dicionário da música brasileira, é visível a grande quantidade de material que ele juntou ao longo da vida sobre este gênero ${ }^{167}$.

Particularmente sobre o maxixe, o historiador Arnaldo Contier citou o artigo de Mário de Andrade "Originalidade do maxixe" (1930) como uma amostra do desprezo que sentia pela música popular urbana Mas, note-se que o mesmo Mário de Andrade definiu seu sentimento para com o maxixe como um "entusiasmo relativo" porque, depois de analisar musicalmente alguns deles, concluiu que suas melodias não eram originais e não podiam ser consideradas como índices de brasilidade. $\mathrm{O}$ único ingrediente que Mário de Andrade encontrou como característico no maxixe

${ }^{164}$ Andrade. Ensaio sobre a música brasileira. [1928] p. 37 e 66.

Esta mesma observação foi feita por Alberto Cavalcanti ao analisar o Ensaio sobre a música brasileira de Andrade: "Nesse primeiro momento, Mário reunia, como «popular», ou como parte do «populário brasileiro», a criação folclórica mais ou menos tradicionalizada, a criação ainda recente, mas anônima e freqüentemente coletiva, e a criação de autoria identificável, inclusive a editada e a gravada e vendida em discos e em partituras" (Cavalcanti, Alberto R. Música popular: janela-espelho entre o Brasil e o mundo. (Teses) Univesidade de Brasilia (UnB), 2007, p. 6).

165 Sánchez de Fuentes. El folk-lor en la música cubana. 125 .

166 Andrade. "Ernesto Nazaré." [1926] Música, doce música. Estudos da crítica e folclore, p.

${ }^{167}$ Andrade. Dicionário Musical Brasileiro. 
estava no ritmo, ou, mais claramente, na interpretação que se fazia dele, "com jeitinho" especial ${ }^{168}$.

De qualquer forma, fica claro nesse artigo que, em 1930, Mário de Andrade já identificava um tipo de folclore urbano que, dizia ele, era normal no mundo, mas tinha algumas enfermidades hereditárias temíveis, como a banalidade na melodia. Do ponto de vista dos elementos musicais, Mário de Andrade considerou que:

Todas as criações urbanas, ou fixações urbanas são em geral assim, e a prova mais definitiva foi a introducção nos foxtrotes e outros cortes rítmicos em que o jazz se manifesta, de linhas de Bach, de Rimsky e até brasileiras. O jazz continuou jazz, sem perder os seus valores essenciais ${ }^{169}$.

Outro mecanismo pelo qual Mário de Andrade acabou inserindo a música da cidade em seus trabalhos foi a inclusão de um canto recolhido em Araracuara, de um palhaço que havia chegado da cidade, em seus artigos "Romance do Veludo"170 e "Lundu do escravo"171. Ainda em seus últimos anos de trabalho, Andrade manteve dentro da categoria música popular-folclórica algumas expressões urbanas, conforme ilustra a voz do compositor Janjão, personagem de O banquete (1943), quando este disse que faltava estudar a música folclórica brasileira porque dela só se conhecem as manifestações do Nordeste e a música urbana, como se tudo pertencesse desse no mesmo $^{172}$.

É possível que a formação autodidata e a grande curiosidade intelectual de Mário de Andrade não o tenham levado somente a caminhar por diversos temas do mundo das artes, mas que também o tenham feito pensar, desde a juventude, que o estudo da música popular não podia ser guiado somente pelo gosto pessoal, mas devia ser amplo de tal forma que o próprio pesquisador chegasse a conclusões, talvez, inesperadas.

168 Andrade, Mário de. "Originalidade do maxixe." Ilustração musical. v. 2, (1930).

Sobre a importância e questões que o maxixe provocou em Mário de Andrade, ver: Machado, Cacá. O enigma do homem célebre: ambição e vocação de Ernesto Nazareth. São Paulo: Instituto Moreira Salles, 2007.

${ }^{169}$ Andrade. "Originalidade do maxixe." p. 45. folclore.

170 Andrade. "O romance do Veludo." [1928] Música, doce música. Estudos da crítica e

${ }^{171}$ Andrade. "Lundu do escravo." [1928] Música, doce música. Estudos da crítica e folclore.

172 Andrade. O banquete. [1943] p. 151. 
Os «sujeitos importantes» devem dar a importância deles pros homens populares, mais importantes que os tais. Se deve registrar tudo o que canta o povo, o bom e o ruim, mesmo porque desse ruim ninguém sabe tudo que pode tirar um bom ${ }^{173}$.

De acordo com a citação anterior, parece que, para Mário de Andrade, as preferências musicais não deviam influenciar na hora de se escolher o que estudar. Não obstante, isso não impedia que ele tivesse um gosto pessoal pois, em 1931, confessou diante de leitores ingleses que "as milhores manifestações da canção brasileira são de origem rural"174. Nesse mesmo artigo, também insistiu sobre o valor da música urbana, independentemente de seu gosto pessoal:

...são inumeráveis os maxixes e sambas valiosos que têm aparecido na imprensa musical e na discografia brasileira para que os possa citar. Os maxixes impressos de Nazaré, de Tupinambá, de Sinhô, todos compositores populares de danças nossas, caracterizam bem esse gênero da nossa música ${ }^{175}$.

Entre seus contemporâneos latino-americanos, ao contrário, era habitual apelar para argumentos de beleza para justificar a recopilação da música popular. Herdeiros do espírito de colecionador do século XVIII, como o argentino Juan Alfonso Carrizo - autor de volumosos tomos de poesia popular argentina cantada —, recorreram a esse argumento para chamar a atenção ao valor do material: " $L a$ genuina poesía popular es florecilla que nace en el campo y se alimenta de sentimientos tan puros como el aires de las cumbres y está nutrida por la savia bienhechora de la tradición que la robustece [...]" ${ }^{\prime 176 .}$

A inclusão de fenômenos urbanos dentro do estudo da música popular tampouco se deu somente na obra de Mário de Andrade. Outros escritores latinoamericanos não deixaram passar desapercebidos os fenômenos urbanos e os reconheceram, em alguma medida, como parte de sua música popular. Na América Central, além de Callejo y Ferrer ter incluído a música das cidades em sua classificação da música popular, também o mexicano Rubén M. Campos incluiu uma manifestação musical urbana dentro de seu inventário dos gêneros folclóricos de seu país. Campos mencionou as canções "charaperas" e esclareceu que "son las que proceden del pueblo de las ciudades y han recibido ese nombre de la bebida regional

173 Andrade. "Ernesto Nazaré." [1926] Música, doce música. Estudos da crítica e folclore, p. 130.

174 Andrade. "A música no Brasil." [1931] Música, doce música. Estudos da crítica e folclore, p. 23.

175 Ibid., p. 20.

176 Carrizo. Antiguos cantos populares argentinos. p. 21. 
llamada «charape» $[. . .]^{177 » "}$. Embora essas canções parecessem não compor um gênero musical enquanto tal, o que chamou atenção foi sua menção ao "povo das cidades". Nem por isso Campos foi benévolo com a vida urbana, e, umas páginas mais adiante, afirmou que a cidade era um "meio corrupto" onde era melhor que os músicos populares não vivessem ${ }^{178}$.

$\mathrm{Na}$ mesma época, outro autor da América central, Julio Arzeno, ao apresentar o objetivo de seu livro Del folk-lore musical dominicano, esclareceu que o material recolhido havia sido encontrado tanto no campo quanto na cidade, onde se encontravam "algunas tonadas y cantares de puro y auténtico criollismo, de nuestro pueblo urbano e rural' 179 .

Efetivamente, Arzeno incluiu na música popular dominicana tanto as expressões camponesas quanto as urbanas, embora, assim como Mário de Andrade, tenha afirmado que as camponesas eram as que melhor expressavam "el genuino sentir dominicano" 180 . Não obstante, o material urbano teve alguma relevância em sua obra, posto que o levou a dividi-la em duas partes: a primeira intitulada "música camponesa" e a segunda, "música popular", dedicada à música "empleada por nuestro pueblo urbano". Na seção sobre o bolero, ressaltou a importância que tinha a música popular urbana para a identidade dominicana:

[...] y la estrecha relación que existe entre el baile y el canto popular urbano, afectó de manera inevitable el estilo musical de nuestro país y desde entonces, lo ha adoptado nuestro pueblo urbano para expresar todas las situaciones, afectos, admiración y vicisitudes que la pasión pueda suscitar, hasta el punto que no hay suceso por simple que fuere, que no sea celebrado por medio del Bolero ${ }^{181}$.

Na década seguinte, o médico Miguel Galindo cunhou a expressão “música popular citadina" quando se referiu aos fenômenos musicais urbanos. A sua maneira de ver a "música popular citadina" teve raízes no âmbito cortesão, e foi delineada após a independência mexicana. De acordo com o ele, a música, sob a influência do ambiente republicano, foi-se:

«estratificando» por decirlo así, quedando en la capa más inferior, la música primitiva, reducida a las poblaciones indígenas; la música campesina, propiamente

\footnotetext{
${ }^{177}$ Campos. El folklore y la música mexicana. p. 86.

178 Ibid., p. 88.

179 Arzeno. Del folk-lore musical dominicano. p. 16.

${ }^{180}$ Ibid., p. 15.

181 Ibid., p. 100.
} 
mestiza, en los ranchos y alquerías; la música citadina, también mestiza pero menos que la anterior, en los pueblos y ciudades, y penetrándola todas, extendida en todas partes, la música religiosa $[\ldots]^{182}$.

Embora em seu livro, Galindo tenha uma narrativa um pouco desorganizada seja temática seja cronologicamente, parece que, para ele, a música popular citadina fez-se visível no século XIX, em meio às mudanças sociais que se produziram, como o crescimento de áreas pobres nas cidades, com habitantes de origem ou ligação rural:

resultó de esas condiciones sociales un curioso fenómeno: en el centro de la capital $\mathrm{y}$ en las poblaciones de alguna importancia, un arte erudito en plena decadencia marchando al aniquilamiento completo. A su alrededor un arte popular que no era otra cosa que mezcla de retazos de erudición, y de música y canto popular con fisonomía española, [...] y un género de música extraña que tenía ritmos superpuestos y que florecía espontáneo y selváticamente en los campos y al rededor de las poblaciones, en los suburbios o arrabales, cultivado por la gente que, aunque viviendo en esas poblaciones, formaba la clase humilde trabajadora de los campos; esa música y cantos a la vez es la de los sones, huapangos y velonas, y finalmente los restos de las danzas indígenas $[\ldots]^{183}$.

Por outro lado, existiu outro grupo de autores que, mais fiéis à definição de música popular vigente para o folclore, desprezaram as manifestações musicais urbanas em seus relatos e privilegiaram a descrição da música rural ou da erudita. Alguns fizeram rápidas menções à música urbana para esclarecer que se tratava de música sem valor artístico ou nacional, e até criaram termos pejorativos para denominá-la, como populachera ou submúsica, como se verá no terceiro capítulo. Além disso, houve tentativas isoladas de especificar que a música urbana não merecia o adjetivo popular.

Em 1916, o crítico e músico Gustavo Santos quis precisar a terminologia que estava sendo manejada em torno da música nacional. Depois de argumentar que a Colômbia carecia "de la canción popular propiamente dicha" — baseando-se no exemplo francês —, referiu-se à notoriedade da música urbana, e, com certo desgosto, disse que, quando se falava de música popular o conceito referia-se à música urbana.

El canto popular entre nosotros no puede ser sino el producto de las ciudades, y su repertorio no puede estar compuesto sino de variaciones de tonadas vulgares

182 Galindo. Nociones de la historia de la música mejicana. p. 404.

183 Ibid., p. 386. 
importadas, porque a esta clase de cantores les da el nombre su voz, y no el ser intérprete del alma popular ${ }^{184}$.

Para diferenciar a música das cidades - mal denominada de popular, segundo a opinião do autor — e a música realmente popular, Gustavo Santos perguntou retoricamente se esses ares denominados nacionais e de caráter urbano poderiam constituir o "nosso folclore", para responder que não, que "em nenhum caso", porque:

[...] ninguna de estas canciones sale del pueblo o llega a él; salen de ciertos medios románticos, y allí encuentran sus éxitos. Pero no confundamos estas asociaciones de ideas con la música verdaderamente popular, no concluyamos, porque nos conmueven por razones de índole personal, que aquellos aires son la síntesis del alma musical de nuestro país ${ }^{185}$.

Os "meios românticos" aos quais Santos referia-se era o dos músicos urbanos, que, como Emilio Murillo, estavam criando vínculos fictícios entre sua música e um ambiente camponês romantizado. Essa era a música de caráter urbano com influências estrangeiras, que começava a circular nas gravações de discos Victor e Columbia, e que Gustavo Santos dizia ser "impropriamente chamada popular".

No caso brasileiro, uma década depois da morte do Mário de Andrade, surgiu um interessante debate entre os folcloristas para definir seu objeto de estudo. Entre as premissas das quais se partiu com esse objetivo, pode-se notar a influência do pensamento de Mário de Andrade em relação à importância que o meio urbano tinha para a configuração do panorama musical do seu país. Particularmente, sequelas dessa postura são encontradas entre seus amigos Renato de Almeida e Oneyda Alvarenga, pois Almeida insistiu que "O contato contínuo da cidade com o campo, do ambiente popular com o urbano, a intercomunicação das capas sociais, é o que torna difícil separar em muitos casos a folcmúsica da música popular"186. Como já se mencionou, nesse escrito, Almeida citou e aceitou as definições que Oneyda Alvarenga elaborou de música folclórica e música popular, nas quais se percebe que o fenômeno musical urbano precisava ser diferenciado. A aluna de Mário de Andrade propunha definir assim os dois termos:

184 Santos, Gustavo. "De la música en Colombia." [1916] In: Hjalmar de Greiff, et al. (ed.), Textos sobre música y folklore, Bogotá: Instituto Colombiano de Cultura, 1978, p. 297.

185 Ibid., p. 198.

${ }^{186}$ Almeida. "Música folclórica e música popular." p. 12. 
Música folclórica é a música que, sendo usada anônima e coletivamente pelas classes incultas das nações civilizadas, provêm de criações também anônimas e coletivas delas mesmas ou da adoção e comodação de obras populares ou cultas que perderam o uso vital nos meios onde se originaram.

Essa música deriva de processos técnicos formadores muito simples, não subordinados a qualquer teorização. Transmite-se por meios práticos e orais. Nasce e vive intrinsecamente ligada a atividades e interesses sociais. Condiciona-se às tendências mais gerais e profundas da sensibilidade, inteligência e índole coletivas, o que the confere um elevado grau de representatividade nacional. E ao mesmo tempo que possui a capacidade de variar, transformar e substituir as obras criadas ou aceitas, revela uma tendência acentuada para ajustar essas mudanças a uma continuidade de processos formadores específicos, que, além de lhe darem uma relativa estabilidade, lhe conferem estrutura e caráter próprios.

Música popular é a música que, sendo composta por autor conhecido, se difunde e é usada, com maior ou menos amplitude, por tôdas as camadas de uma coletividade.

Essa música usa os recursos mais simples ou mesmo rudimentares da teoria e técnica musicais cultas. Transmite-se por meios teóricos convencionais ou por processos técnico-científicos de divulgação intensiva: grafia e imprensa musicais, fonografia, radiodifusão. Tem o seu nascimento, difusão e uso geralmente condicionados às modas, tanto nacionais quanto internacionais. $\mathrm{E}$ ao mesmo que revela por isso um grau de permabilidade e mobilidade que a tornam campo permanentemente aberto às mais várias influências, possui um certo lastro de conformidade com as tendências musicais mais espontâneas, profundas e características da coletividade, que lhe confere a capacidade virtual de folclorizar$\mathrm{se}^{187}$.

Infelizmente, a morte precoce de Mário de Andrade deixou incógnitas a respeito da concepção que esse intelectual possuía no que tange ao crescimento da música popular urbana em seu país e da sua relação com o conceito de música popular. $\mathrm{O}$ artigo que deixou escrito para acompanhar a seção sobre folclore, no Manual bibliográfico de estudos brasileiros (1949), dá mostras de que o pensamento de Mário de Andrade sobre esses fenômenos não estava completamente explicado em seus escritos anteriores pois, além da crítica que fez ao folclore, parece que o escritor paulistano pensava sua categoria de música popular-folclórica de uma maneira mais complexa, que ultrapassa a simples justaposição entre o rural e o urbano. Nesse escrito, o autor acusou de certo "confusionismo absurdo" o ato de se chamar folclórico a "qualquer romance de cantador e qualquer peça urbana de autor" 188 . Embora não haja indicado quais deveriam ser as pautas a ser seguidas para evitar tal confusão, possivelmente uma delas estava relacionada à ideia de popularesco, que

${ }^{187}$ Ibid., pp. 9-10.

188 Andrade. "O folclore no Brasil." [1949] Manual Bibliográfico de Estudos Brasileiros, p. 442. 
havia desenvolvido em sua última época, e sobre a qual voltar-se-á no terceiro capítulo.

Em síntese, tudo parece indicar que, à medida que a música popular urbana consolidou-se, ela começou a ser tratada com desconfiança, sobretudo por quem adotara doutrinariamente o conceito de música popular oferecido pelo folclore. Ao mesmo tempo, houve outros autores que, com certa "inocência", não encontraram maiores problemas para compreender também como música popular, certa música que rondava por suas cidades e que, claramente, era diferente da música erudita, mas não o era da música rural.

\section{Características da música popular}

Viu-se que o conceito de música popular esteve fortemente influenciado pelo folclore e por sua visão de mundo romântica, e que os autores estudados adotaram essas premissas, muitas vezes sem as problematizar, mas que, ao confrontálas com suas realidades, houve quem fizesse certos "malabarismos" para cortar a distância entre a teoria e aquilo que acontecia em seu meio. Não obstante, é provável que a maioria dos autores concordasse com o compositor colombiano Guillermo Uribe Holguín, em dizer que:

La música popular se distingue por cualquiera de sus elementos constitutivos, y aun por su misma instrumentación, pero particularmente por el ritmo y la melodía, porque la armonía es un elemento complejo, comúnmente inaccesible al que no es profesional. Empero la misma armonía, y con más frecuencia las escalas, y modalidades, son en algunos casos característicos de esta música ${ }^{189}$.

Com algumas exceções, como a anterior, era comum que, aqueles que se interessavam pelo estudo da música popular, omitissem as particularidades musicais gerais, de modo a definir somente as características consideradas como nacionais. Com isso, quer-se chamar a atenção para o fato de que muitos autores parecem ter partido da definição de música popular, dada pelo romantismo, embora a caracterização romântica não haja sido musical. De um modo geral, sem pensar se a música popular tinha ou não elementos musicais definidores, os esforços dos autores em analisá-la concentraram-se em encontrar o que fazia dela representante da

189 Uribe Holguín. Vida de un músico colombiano. [1941] p. 120. 
nacionalidade de seus países. Naturalmente, essa preocupação esteve em sintonia com os problemas que o nacionalismo musical levantava.

Este capítulo termina com uma leitura das entrelinhas dos textos dos autores, visando à identificação e proposta de um tipo de caracterização musical genérica que os autores outorgaram, subterraneamente, à música popular. Essa preocupação é um caminho a mais para continuar a aproximação do conceito de música popular, que provavelmente se manejou durante o período em estudo, mas cuja complexidade impediu a atribuição de uma definição que pudesse ser tomada por consensual.

Curiosamente, embora alguns dos escritores fossem músicos e conhecessem bem seus princípios teóricos, o único autor encontrado que lançou mão de uma caracterização musical genérica foi o compositor cubano Gaspar Agüero. Em 1920, ele disse que a música popular era música "producida por el pueblo, desatendiendo los cánones establecidos por los teóricos y tratadistas muchas veces, o cumpliéndolos otras por un instinto singular". De acordo com Agüero, essa música distinguia-se por possuir três particularidades:

1. No utiliza sino ritmos fijos

2. Sus melodías son fáciles, y se ajustan como la forma poética a una métrica especial, ofreciendo una simetría verdadera, en la extensión de sus frases y periodos.

Por último, su armonía, y este es su lado débil, es pobrísima en recursos; anémica de acordes ${ }^{190}$.

Mais adiante, o autor acrescentou outra particularidade mais abstrata, "la virtud de expresar el sentimiento del compositor tal como nace de su alma". Embora o escrito de Agüero versasse sobre a música popular cubana, o autor partiu do geral para o particular e, antes de se referir ao caso cubano, arriscou essa caracterização, destacando-se como um dos poucos autores a fazê-lo.

Embora Mário de Andrade não haja tornado pública uma definição do que considerava como música popular-folclórica, fez-se o exercício de buscar, ao longo de seus escritos, algumas características, ou melhor, alguns princípios, que considerava comuns na música que circulava no campo e nas cidades, e que p. 6 .

190 Agüero. Consideraciones sobre la música popular cubana: (a) sus defectos (b) sus bellezas. 
poderiam vir a ser considerados como delineadores, em alguma medida, de seu conceito de música popular.

Por um lado, em seu Ensaio sobre a música popular brasileira (1928), ele ofereceu uma caracterização do caso musical brasileiro por meio de uma análise de 126 melodias consideradas populares, recolhidas pessoalmente e por correspondência. Delas, analisou o ritmo, o contorno melódico, a harmonia, a instrumentação e a forma musical.

Dessa amostra, Mário de Andrade concluiu que, no que tange ao ritmo, a música popular brasileira apresentava um predomínio de ritmos binários, e que esse era um dos aspectos mais ricos e complexos de se estudar. Essa complexidade surgia porque a teoria e a escritura musical europeias eram deficientes para o estudo de fenômenos rítmicos como a síncope, cuja natureza, no caso brasileiro, estava ligada ao ritmo do português falado, ou ritmo livre, e à polirritmia.

No nível melódico, existiam tendências ao uso de saltos de sétima, de oitava e de nona, de modos hexacordais sem sensível, além do predomínio de frases descendentes. Em relação à harmonia, predominava o sistema tonal europeu, embora se encontrassem casos de modos hipofrígio e hipolídio. A instrumentação era importada, mas certos timbres adquiridos pelos instrumentos eram brasileiros. Quanto à forma, não havia elementos originais, mas era notória a preponderância da melodia com acompanhamento, a forma estrófica e a dança.

Essa caracterização da música popular brasileira não pretendia ser definitiva, mas sim era um convite para que seus colegas a continuassem estudando e contribuíssem para a matéria ${ }^{191}$. Uns anos depois, Mário de Andrade reconheceu que:

$\mathrm{Na}$ verdade a música popular brasileira, apesar de tão exteriormente característica, ainda é um caos. A gente encontra nela desde sutilezas harmônicas eruditas até primaridades de selvícola, que se diria inventadas por um Veda, do Ceilão ${ }^{192}$.

191 No momento em que o Ensaio sobre a música brasileira (1928) foi publicado, o nacionalismo era uma espécie de contradiscurso diante da presença da música italiana e francesa, tanto no Rio de Janeiro quanto em São Paulo. Seu tom parecia revolucionário à elite acadêmica, ligada à estética europeia e acostumada a menosprezar a cultura brasileira (Contier. Brasil Novo. Música, nação e modernidade: os anos 20 e 30. p. 169).

192 Andrade. "Lourenço Fernandez (Sonatina)." [1931] Música, doce música. Estudos da crítica e folclore, p. 181. 
Há que se ter em conta que o Ensaio sobre a música brasileira (1928) foi o primeiro trabalho a se deter sobre o estudo da música como tal, quer dizer, foi o primeiro que analisou as melodias dos cantos de que outros folcloristas brasileiros apenas transcreveram as letras ${ }^{193}$. Possivelmente graças a isso, Mário de Andrade enfocou a matéria musical e lhe forneceu um tratamento analítico. Seu livro foi lido e admirado, não só por colegas brasileiros, mas também por estudiosos latinoamericanos que sentiam falta desse tipo de trabalho e - como se viu no primeiro capítulo - entraram em contato com ele por correspondência para manifestar sua simpatia.

Além disso, Mário de Andrade reconhecia que as características musicais anteriores não eram exclusivas da música brasileira, constando também da música de outros lugares, mas essas características poderiam não chegar a caracterizar a música de outros lugares como ocorria com a música do Brasil. Com tais características, o autor só tentava mostrar elementos constantes da música do Brasil, e não da música popular em geral, ou seja, que as características mencionadas não poderiam ser entendidas como uma descrição do que era, para ele, a música popular enquanto categoria taxonômica. Em outras palavras, ditas categorias tinham apenas a função de caracterizar a música brasileira.

Não obstante, considera-se que Mário de Andrade tinha em seu inconsciente intelectual uma caracterização musical mais genérica daquilo que considerava música popular. Os parâmetros que norteiam essa caracterização mais ampla ficam sugeridos nas entrelinhas de um trecho do Ensaio sobre a música popular (1928), no capítulo sobre a melodia, que pode ser complementado com outra bibliografia de sua autoria. Embora para o nosso autor paulistano as particularidades que serão mencionadas estivessem presentes em toda a música, parece que aquilo que caracterizava a música popular era sua presença mais intensa. Vejamos:

No capítulo da obra supracitada, Mário de Andrade tentou entender se a música, em geral, é psicologicamente inexpressiva, entrando no mérito do problema da expressividade do ponto de vista estético. Em sua argumentação, Andrade disse que a música não é expressiva como a palavra, mas somente dinamogênica e, como

193 Vilhena. Projeto e Missão. O movimento folclórico brasileiro 1947-1964. p. 131. 
consequência, cria estados cenestésicos ${ }^{194}$. Adiante, Andrade pergunta, retoricamente, o que a música popular fazia com esses poderes dinamogênicos, e respondeu com as seguintes palavras::

É sempre fortemente dinamogenica. É de dinamogenia sempre agradavel porque resulta diretamente, sem nenhuma erudição falsificadora, sem nenhum individualismo exclusivista, de necessidades gerais humanas inconscientes. E é sempre expressiva porque nasce de necessidades essenciais, por assim dizer interessada do ser e vai sendo gradativamente despojada das arestas individualistas dela á medida que ser torna de todos e anônima. E como o povo é inconsciente, é fatalisado, não pode errar e por isso não confunde umas artes com as outras, a música popular jamais não é expressão das palavras. Nasce sempre de estados fisiopsiquicos gerais de que apenas também as palavras nascem. E por isso em vez de ser expressiva momento por momento, a música popular cria ambientes gerais, cientificamente exatos, resultantes fisiologicas da graça ou da comodidade, da alegria o da tristura ${ }^{195}$.

A partir dessa declaração, e de outras citações, propõe-se considerar que Mário de Andrade entendeu por música popular um tipo de música que cumprisse com as seguintes propriedades:

\subsection{Da propiedade Monódica}

Em 1926, falando sobre a música do Ernesto Nazareth, disse que o compositor harmonizava cromaticamente a "essência monódica da música popular" 196 , e no ano seguinte, no artigo "Luciano Gallet. Canções brasileiras", afirmou que,

A moda popular até não carece propriamente do elemento harmônico. Ela é de fundamento monódico, quer seja monodia vocal quer instrumental. A base harmônica do canto popular, não está no possível acompanhamento que a gente possa ajuntar a ele, está na propria evolução da melodia que se sujeita às relações hierárquicas que os sons adquirem dentro dos sistemas sonoros, quer sejam modais quer tonais ${ }^{197}$.

Sobre esta característica, tornou a se referir em 1940, quando disse que a música popular era essencialmente vocal e que este era o elemento que fazia que fosse monódica ${ }^{198}$.

194 E continuava afirmando: “...como as dinamogenias dela não têm significado intelectual, são misteriosas, o poder sugestivo da música [popular] é formidável." Andrade. Ensaio sobre a música brasileira. [1928] p. 41.

195 Ibid., pp. 41-42. 124.

196 Andrade. "Ernesto Nazaré." [1926] Música, doce música. Estudos da crítica e folclore, p.

197 Andrade. "Luciano Gallet. Canções brasileiras." [1927] Música, doce música. Estudos da crítica e folclore, p. 173. 321-322.

198 Andrade. "Ernesto Nazareth." [1940] Música, doce música. Estudos da crítica e folclore, pp. 
Outro músico hispano-americano, cujo livro Mário de Andrade não conheceu, também emprestou especial atenção à melodia da música que ele considerou popular. Fernando Callejo Ferrer, cuja história da música em Porto Rico caracteriza-se por uma presença notória da análise musical como ferramenta de estudo, argumentou que, embora a arte musical seja uma só, existem diferenças entre seus gêneros, assim como a linguagem tem diferentes idiomas e dialetos. Nesta ordem de ideias, Callejo Ferrer propôs que a principal característica da música popular estava em suas melodias singelas e, embora não se tenha referido a elas como monódicas, ressaltou suas fermatas longas e terminações em semicadências ${ }^{199}$. Uns anos depois, Carlos Vega insistirá na marcada influência do canto gregoriano que era monódico — na música popular de seu país.

\subsection{Da propriedade Dinamogênica}

Em geral, a importância do ritmo dentro da música popular foi um lugarcomum entre os músicos que se ocuparam de seu estudo analítico. Em Cuba, Eduardo Sanchez de Fuentes procurou esclarecer, em seu artigo "Música popular" (1928), que "No son los ritmos solamente los que determinan la naturaleza de la música. El ritmo, que es el alma de la melodía, según se ha dicho, constituye uno de los factores identificativos de la producción musical...", com o quê parece que a importância do ritmo estava aceita na caracterização da música popular. Em artigo posterior, Sánchez de Fontes continuou dizendo:

La música representativa de los diversos países que existen en nuestro planeta acusa en cada uno de ellos, por regla general, características rítmicas que con otras que emanan de distintas causas, contribuyen a que sea fácil la labor de identificación y nomenclatura $[\ldots]^{200}$.

Em certa medida, parece que estava claro que uma das maneiras de se distinguir musicalmente tipos ou gêneros musicais era por meio da análise de seu ritmo, em conjunção com outros elementos. Portanto, seria possível pensar que o mesmo se daria com a música popular, de tal maneira que seria possível saber se algo era popular conforme indicassem suas "características rítmicas que con otras que emanan de distintas causas".

199 Callejo Ferrer. Música y músicos portorriqueños. p. 274.

200 Sánchez de Fuentes. Folklorismo; artículos, notas y criticas musicales. p. 37. 
Seu colega e conterrâneo Gaspar Agüado, ao falar sobre música popular, mencionou a capacidade que seu ritmo tinha de fazer com que a audiência movessese de acordo com ele, e iniciou sua caracterização da música popular cubana com a seguinte explicação:

El ritmo es el primer motivo de seducción musical, y, para muchas personas, quizá sea el único; produciendo, en no pocas, un reflejo peculiar que les obliga a marcar dicho ritmo golpeando inconscientemente con los dedos sobre cualquier cosa a guisa de pandero ${ }^{201}$.

No México, Miguel Galindo também encontrou uma relação direta entre música popular e ritmo. Talvez por sua formação como médico, prestou maior atenção ao triângulo configurado entre a música popular, o ritmo e o baile, pois observou que essa música tinha algo que gerava o desejo de mover o corpo seguindo seu ritmo. Possivelmente por estar acostumado a pensar a relação das mudanças do corpo humano com seu ambiente, como propunha a medicina microbiana e higienista do momento, levou em conta esse fato. "Basta oír una música alegre de ritmo fácilmente comprensible, y aun sin pensarlo se siente el impulso al baile"202. Quando este autor procurou diferenciar a música litúrgica da profana - dentro da qual se encontrava a popular, segundo sua classificação — , enfatizou que essa diferença era dada pelo ritmo, o qual era "assimétrico", talvez sentindo algum tipo de síncopa ou de polirritmia.

Lo que distingue fundamentalmente la música litúrgica o eclesiástica de la profana, lo que le imprime su intenso e innegable sentimentalismo y su elevación grandiosa, es la falta de cromatismo y la poca precisión y ninguna simetría del ritmo ${ }^{203}$.

Mário de Andrade também mostrou grande curiosidade pelos fenômenos dinamogênicos em torno da música. Ao que parece, para ele, a música popular possuía um poder dinamogênico particular, isto é, que levava à acumulação de energia no corpo e desencadeava o movimento deste (a dinamogenia era criada pelo ritmo, e seus efeitos eram fisiológicos).

O poder dinamogênico da música interessou a Mário de Andrade durante toda sua vida, e ele aproximou-se do estudo da medicina para encontrar algumas

\footnotetext{
p. 4.

${ }^{201}$ Agüero. Consideraciones sobre la música popular cubana: (a) sus defectos (b) sus bellezas.

202 Galindo. Nociones de la historia de la música mejicana. p. 151.

203 Ibid., p. 129.
} 
respostas a este e outros assuntos ${ }^{204}$. O tema do ritmo e da dinamogenia, para ele, estava relacionado com o problema maior da "atuação da música sôbre o ouvinte, a extensão e intensidade do seu poder num nível fisio-psicológico, a natureza dêsse poder"205. Parece que seu apelo ao poder dinamogênico da música não passou desapercebido para outros conterrâneos, como Orestes Barbosa, que em seu livro sobre o samba, disse que "cientificamente, sabe-se que a música se infiltra no organismo"206.

\subsection{Da propriedade Efeitos fisiopsíquicos}

Por outro lado, e afastando-nos da caracterização musical, talvez a aproximação rápida que Mário de Andrade teve da medicina o tenha levado a pensar que a música nascia de estados fisiopsíquicos e, por isso, a música popular particularmente, era muito expressiva. Por esse caminho, nosso autor chegou ao tema da expressividade, em que coincidiria, de certa forma, com o olhar romântico sobre o fenômeno musical, mas não completamente. Para compreender melhor sua postura frente à expressividade, é bom lembrar sua compreensão do romantismo e do poder de comunicação da música.

A princípio, Mário de Andrade, como a maioria de seus colegas, entendeu por romantismo um período da história artística com particularidades estéticas e filosóficas, e ali encontrou dois dos temas que mais lhe interessariam durante a vida: a função da música popular e a expressividade musical em relação ao binômio musical-palavra, muito afim com seu duplo ofício de escritor e músico.

Em seu Compêndio da história da música (1929), Mário de Andrade apresentou sua interpretação a respeito do modo como o romantismo do século XIX interessou-se pelo popular. Nesse texto, fez uma leitura diferente da que era feita pela historiografia tradicional sobre o serviço que a música popular havia prestado à erudita, e disse que, na realidade, o romantismo oitocentista havia criado uma

204 Este tema pode ser ampliado com a leitura do seu artigo "Terapêutica musical" (Andrade, Mário de. "Terapêutica musical." [1939] In: Oneyda Alvarenga (ed.), Namoros com a medicina, São Paulo: Livraria Martins Editores, 1972).

205 Coli. "Mário de Andrade - Introdução ao pensamento musical." p. 115.

Em 1929, Mário de Andrade publicou no Diário Nacional, um escrito pequeno em que afirmou que as dinamogenias eram uma qualidade própria da música, entre as outras artes (Andrade. "Taxi: Pessimismo divino." [1929] Taxi e Crônicas no Diário Nacional).

${ }^{206}$ Barbosa. Samba: sua história, seus poetas, seus músicos e seus cantores. [1933] p. 30. 
deformação do "espírito popular". Segundo ele, essa deformação consistia no fato de que, como a música popular caracterizava-se por ser útil — singularidade sobre a qual se voltará mais adiante —, a maneira como o romantismo usou o popular foi agregando à música erudita seu aspecto utilitário, e essa "utilidade agregada" consistiu particularmente na expressão de sentimentos. Segundo a argumentação de Mário de Andrade, poder-se-ia assumir que, na realidade, a "expressão de sentimentos" seria um trabalho da música erudita, enquanto que a música popular teria muitas outras utilidades em que empregaria seu poder expressivo, por sua vez outorgado por sua origem em estados fisio-psíquicos particulares.

Por outro lado, a utilidade da "expressão de sentimentos" acabou por converter a música erudita em uma "linguagem das emoções"207. Do ponto de vista do autor, isso provocou uma série de "mal-entendidos" em relação à maneira como a música podia descrever um mundo extramusical, como se se tratassem de palavras, interpretação a que se opôs ${ }^{208}$. A convicção de que a música era uma linguagem que expressava sentimentos foi comum a toda a literatura musical latino-americana da época, e foi uma das bases sobre as quais foram construídos muitos dos textos consultados $^{209}$.

\subsection{Da propriedade Interessada}

Como já se mencionou, parece que uma das singularidades sociais que Mário de Andrade outorgou à música popular foi a de que se tratava de uma arte interessada, quer dizer, que tinha um uso ou utilidade, diferentemente da arte desinteressada. No mesmo Ensaio sobre a música brasileira (1928), ele afirmou que:

[...] toda arte socialmente primitiva que nem a nossa, é arte social, tribal, religiosa, comemorativa. É arte de circunstancia. É interessada. Toda arte exclusivamente

${ }^{207}$ Andrade. Pequena história da música. [1942] p. 134.

208 Por exemplo, em Porto Rico, Fernando Callejo Ferrer afirmou: "La música es la expresión del sentimiento. Lo que ella expresa es la misma alma en lo que tiene de más íntimo y profundo". E depois insistiu "La música, psicológicamente considerada, es el arte que más poderosos medios de expresión posee para que un artista pueda establecer verdadera comunidad de ideas y de sentimientos cuando traduce, al lenguaje de los sentidos, las impresiones de su numen." (Callejo Ferrer. Música y músicos portorriqueños. pp. 124-168).

209 Por exemplo: "La música es un lenguaje, aunque no concreto, vagoroso, verdaderamente espiritual, y así son las ideas por él expresadas" (Agüero. Consideraciones sobre la música popular cubana: (a) sus defectos (b) sus bellezas. p. 4) ou "[La música] Es un idioma ingénuo y espontáneo que revela en detalle las intimidades del alma individual; pero que en su conjunto da un idea bastante clara y precisa de las corrientes del sentimiento colectivo, quizá con mayor exactitud que el lenguaje articulado." (Galindo. Nociones de la historia de la música mejicana. p. 126). 
artística e desinteressada não tem cabimento numa fase primitiva, fase de construção ${ }^{210}$.

Em "Terapêutica musical” ele também mencionou rapidamente a relação intrínseca entre a música popular e a música interessada, ao dizer que toda música popular, religiosa ou primitiva, tinha uma função terapêutica e, portanto, uma função social interessada ${ }^{211}$.

O ingrediente de utilidade que Mário de Andrade encontrava na música popular, além de sua proveniência de certos estados psicofísicos e do seu potencial para veicular as expressões, advinham de elementos que não estavam só nela, mas que também pertenceram à música erudita em certos momentos. Ao que parece, pela leitura do musicólogo do processo histórico, a diferença entre os dois tipos de música estaria no fato de que a música popular conteria necessariamente esses ingredientes, em maior grau.

\subsection{Das propriedades Coletiva e anônima}

Conforme se mencionou, entre as particularidades que o romantismo adjudicou à música popular, está a de ser coletiva e anônima. Essas características também foram mencionadas nos escritos do Mário de Andrade mas, para o autor, coletividade e anonimato eram justificados de forma ligeiramente diferente daquela indicada pelo folclore.

A seu modo de ver, a coletividade e o anonimato seriam uma consequência da grande expressividade da música popular, já que era graças a estas que a música conseguia coletivizar-se, esquecendo seu autor. Isso significava que Mário de Andrade não concordava com a ideia de que a criação coletiva fosse um fenômeno possível, tampouco próprio da música popular, tema que o interessou profundamente como artista criador. Seus artigos "Dinamogenias políticas" (1930) e "O samba rural paulista" (1937) são um reflexo dessa preocupação, além de apresentarem um esboço da maneira como pensava esse tipo de criação, que ao folclore parecia coletiva.

$\mathrm{O}$ fato de reconhecer o anonimato como uma característica da música popular, vinculava o conceito de Mário de Andrade à ideia romântica e naturalista,

${ }^{210}$ Andrade. Ensaio sobre a música brasileira. [1928] p. 18.

211 Andrade, Mário de. Namoros com a medicina. [1939] São Paulo: Livraria Martins Editores, 1972 , p. 24. 
muito bem expressa por Afonso Arinos, de que "A trova anónyma é um producto natural como a planta que rebentou e floriu, sem ser semeada nem cultivada por mão do homem, no meio do campo maninho"212. Mas, apesar da similitude superficial, nosso autor fez uma interpretação diferente. Em seu artigo de 1926, explicou a seu público que:

O que faz a intensidade concentrada da arte popular é a maneira com que as fórmulas melódicas e rítmicas se vão generalizando, perdendo tudo o que é individual, ao mesmo tempo que concentram em sínteses inconscientes as qualidades, os caracteres duma raça ou dum povo. A gente bem sabe que uma melodia popular foi criada por um indivíduo. Porém esse indivíduo, capaz de criar uma fórmula sonora que iria ser de todos, já tinha de ser tão pobre de sua individualidade, que se pudesse tornar assim, menos que um homem, um humano. E ainda não basta. Rarissimamente um canto de deveras popular, é obra dum homem apenas. O canto que vai se tornar popular, nesse sentido legítimo de pertencer a todos, de ser obra anônima e realmente representativa da alma coletiva e despercebida, si de primeiro foi criado por um indivíduo tão pobre de individualidade que só pôde ser humano - e que riqueza essa! - o canto vai se transformando um pouco ou muito, num som, numa disposição rítmica, gradativamente, e não se fixa quasi nunca, porque também a alma do povo não se fixa ${ }^{213}$.

Esse mesmo enfoque foi trazido de volta, em 1941, para sustentar seu argumento sobre o desnivelamento da modinha em resposta ao trabalho de Roger Bastide, "Estudos de sociologia. Estética brasileira"214.

Ao que parece, Mário de Andrade não foi o único a duvidar de que a música popular surgiu de uma criação coletiva, pois, uns anos antes, Amadeu Amaral teve a mesma opinião. Em um artigo manuscrito, que foi publicado depois de sua morte, o ensaísta brasileiro afirmou que "O povo como massa, não compõe coisa alguma. Aquilo que ele repete e transmite é sempre «popularizado», sempre proveio de um autor individual, culto ou inculto, não importa"215. Como o texto citado foi publicado em 1948, é possível que Mário de Andrade não o tenha conhecido, embora se saiba que era leitor da obra de Amaral.

A existência de um indivíduo criador por trás de toda música popular foi uma ideia que também ocorreu a Rubén M. Campos, cujo livro Mário de Andrade

212 Arinos. "A música popular." p. 1.

213 Andrade. "Crítica do gregoriano." [1926] Música, doce música. Estudos da crítica e folclore, p. 32. 340.

${ }^{214}$ Andrade. "A modinha e Lalo." [1941] Música, doce música. Estudos da crítica e folclore, p.

215 Amaral, Amadeu. "O popular em matéria folclórica." In: Paulo Duarte (ed.), Tradições populares, São Paulo: Instituto Progresso Editorial S. A., 1948, p. 16. 
conheceu e leu. De forma quase natural, Campos procurou a "origem do folclore" em alguns músicos, e até em mestres de capela, a quem o autor atribuiu a composição de obras do folclore mexicano. Ao que tudo indica, Rubén M. Campos ignorava que o anonimato fosse uma das características que o folclore atribuía à música popular. Pelo contrário, dedicou um de seus capítulos a dar nome próprio aos compositores da música popular-folclórica de seu país.

Também no Chile, duvidou-se da possibilidade de que a criação popular fosse anônima. Ali, entre as pessoas que se interessaram pela cultura popular, e particularmente por sua música, o historiador Eugenio Pereira Salas, em Los orígenes del arte musical en Chile (1941), foi crítico da ideia romântica sobre a criação coletiva e anônima:

Por mucho tiempo, debido a la influencia del romanticismo europeo, se creyó en la existencia de una poesía y una música popular que fueran la obra colectiva de las multitudes; creación anónima, al decir de López Chavarri, de las gentes que viven unidas por íntimos lazos étnicos, que expresan así en sus versos y cantos, sus reacciones frente al mundo en que actúan.

La crítica científica, que vino a reemplazar el fervor romántico, negó la posibilidad de este proceso, y Joseph Bedier al estudiar los grandes ciclos de la poesía caballeresca de Francia medieval, llegaba a muy distintas conclusiones. La más simple canción -según opinión de Bedier- posee una fecha y un autor y los antiguos poemas por él estudiados no son obra del pueblo inculto, sino de gente letrada y erudita $^{216}$.

\subsection{Da propriedade Memorizável}

Em último lugar, para Mário de Andrade, a música popular também era memorizável, e esta particularidade guardava relação com o fato de ser coletiva e anônima. Em sua lógica, para ser coletiva, ela devia ser facilmente memorizável, posto que precisava ser repetida várias vezes. Embora não fossem sempre repetidas da mesma forma, o que se guardava na memória eram as estruturas básicas e, portanto, eram comuns as formas periódicas de rondó e certas fórmulas rítmicomelódicas ${ }^{217}$.

216 Pereira Salas. Los orígenes del arte musical en Chile. pp. 159-160.

${ }^{217}$ Andrade. Pequena história da música. [1942] p. 60.

De acordo com Telê Porto Ancona Lopez, também nos estudos que fez sobre a literatura popular, Mário de Andrade afirmou que o rondó era uma das formas mais usadas e o definiu como uma constante popular que se baseava na tendência repetitiva do povo (Lopez. Mário de Andrade: ramais e caminho. p. 174). 
Em resumo, talvez o conceito de música popular de Mário de Andrade fosse composto de características de cunho musical, psicológico e social. É possível considerar que, para o escritor paulista, a música popular, musicalmente, era monódica, possuía ritmos dinamogênicos e padrões de repetição. Além disso, estava influenciada por algumas particularidades psicológicas, como o nascer de estados fisiopsíquicos especiais, uma vez que era fortemente expressiva e facilmente memorizável. Adicionalmente, ele atribuiu-lhe certas particularidades sociais, como o fato de ser interessada (útil), coletiva e anônima.

Em um dos manuscritos de Mário de Andrade que foram conservados, observa-se que o autor paulista, em certo momento da vida, propôs-se a analisar a radiodifusão e iniciou um documento de trabalho no qual esquematizou o tipo de programação que as cadeias de rádio transmitiam, talvez com o ímpeto de fazer um acompanhamento de seus conteúdos. Nesse esquema, Mário de Andrade diferenciou três grandes blocos: um sobre música, outro com execuções musicais, e um terceiro, que intitulou "complementos", e que contemplava os esportes e os discursos breves. A data desse documento é incerta, mas se suspeita que tenha sido escrito na segunda metade da década de 1930, por terem sido encontrados junto a ele artigos sobre o rádio de outros países, publicados por volta de 1936, e por ser esse o período em que Mário de Andrade esteve ativo no Departamento de Cultura de São Paulo, e mais interessado pelas políticas culturais.

Foi interessante ver que, nesse documento, Mário de Andrade subdividiu o primeiro bloco em música erudita e música popular, e escreveu uma curta definição de cada uma. Esse foi o único escrito encontrado em que o musicólogo brasileiro lançou uma definição de música popular, contrapondo-a à sua "eterna" contrária, a música erudita. Deve-se ter em conta que, o fato de suas palavras terem permanecido ocultas entre seus manuscritos, demonstra que se tratava de um trabalho inacabado, e que, portanto, suas definições podem também ser incompletas, não obstante manterem alguns dos elementos assinalados até o momento: a relação com a formação acadêmica e a necessidade individual ou social.

A música erudita, Mário de Andrade definiu-a, informalmente, assim:

Entende-se toda e qualquer música, cujo autor primeiro estudou pra compor e só depois compôs pra fazer arte. 
Depois, entre parênteses, esclareceu que se tratava da música que surgia de uma necessidade individual, e que, portanto não era anônima:

Na música erudita sempre se tem necessidade de saber o nome do autor, porque a música foi feita principalmente pela necessidade individual interior que o artista tinha de fazer arte. Portanto essa música não é feita para o gasto da vida social, e só, sem necessidade imediata, se liga às condições sociais da vida humana.

Sua definição terminava com um exemplo que ajudava a não confundir o erudito com o popular e enfatizava o caráter útil desse popular:

Uma valsa de Chopin é feita pra se executar e se escutar quando a gente quer, e portanto é música erudita, ao passo que uma valsa de Tupinambá é feita especialmente pra se dansar, e portanto é música popular.

Por sua vez, a definição de música popular seguiu o mesmo esquema:

Entende-se aqui toda e qualquer música cujo autor compõe sem estudar, ou só estudou o mínimo necessário depois de já estar compondo.

Novamente entre parênteses, referiu-se ao surgimento da música popular a partir das necessidades sociais, além de se referir a seu consequente anonimato.

$\mathrm{Na}$ música popular não se tem necessidade de saber o nome do autor, e de-fato muitas vezes ela é anónima. Porque a música popular é principalmente composta pelas necessidades sociais da vida, quer sejam necessidades sexuais como na dansa e na canção, que políticas, religiosas, industriais, familiares, etc., etc., A música popular é portanto composta especialmente pra ser gasta pela vida social, e tem uma necessidade imediata no seu emprêgo.

E terminou esclarecendo, com outro exemplo, que a característica básica da música popular era o seu surgimento de e para a "indústria social".

Entre uma canção do Camargo Guarnieri que primeiro estudou pra depois compor e uma canção de Sinhô pra cinema, carnaval ou serenata, a primeira é música erudita porque não nasceu imediatamente da indústria da vida social, ao passo que a segunda é música popular porque nasceu somente da industria social e pra ela se dirige especialmente ${ }^{218}$.

O uso da expressão "nascer e dirigir-se para a indústria social" remete a um âmbito muito amplo e deixa a sensação de que não se limitava à sociedade rural e utópica - tipicamente defendida pelo romantismo. Será que dentro daquela “indústria social" se incluíam o mundo urbano e o universo da música que circulou nos modernos meios de comunicação eletrônicos? Este será o tema do capítulo seguinte. 
Conforme se procurou ilustrar neste capítulo, é provável que o uso do conceito de música popular como uma categoria taxonômica importante tenha começado a ser frequente no continente latino-americano somente nos primeiros anos do século XX. Parece que, sob a marcada influência que o romantismo exerceu durante esse momento, sua visão de mundo marcou profundamente o conceito nascente e, além de impregná-lo com um sabor de fenômeno antigo, outorgou-lhe características que simplificaram as complexidades trazidas pelo crescimento das culturas urbanas.

Um dos principais usos que, ao que parece, o conceito música popular teve, foi o de ser a antítese de música erudita. A essa oposição, foi atribuída uma existência arcaica e se acreditou que, no passado, ambas haviam estado afastadas uma da outra. Considerava-se que essa distância estava sendo reconciliada pelo nacionalismo, movimento estético para o qual a música popular guardava os verdadeiros traços da nacionalidade. Por esse motivo, ela devia ser resgatada das garras da modernidade e usada como "condimento" fundamental da música nacional erudita. Entretanto, quando se estudou a música popular e se tentou outorgar-lhe a legitimidade da tradição, foi preciso historiá-la e se acabou "caindo em um lodaçal" em que nem sempre se encontrou o que se buscava.

Por outro lado, embora a tendência principal, durante o período em estudo, fosse a de um certo grau de sinonímia entre música popular e música folclórica, nem todos os autores assumiram completamente as características que o pensamento romântico outorgou ao segundo termo. A principal diferença consistiu na inclusão de certos fenômenos urbanos, sobretudo nos escritos mais precoces. $\mathrm{O}$ surgimento de eventuais dúvidas sobre outros aspectos, como o caráter anônimo, a imutabilidade da música popular e suas conexões com a música erudita também complexificou a dicotomia de partida. Entre os autores estudados, observou-se que, em geral, as diferenças entre seus pontos de vista e aqueles advindos das pesquisas do folclore não foram explícitas, o que faz pensar que se pode tratar de um tipo de ecletismo ou postura intermediária entre a teoria que chegava da Europa e as realidades musicais latino-americanas. As exceções a essa atitude foram encontradas nos trabalhos de Mário de Andrade e de Carlos Vega, que discutiram abertamente algumas dessas 
questões e, talvez por isso, foram polêmicos dentro das gerações mais jovens e mais dogmáticas.

Tudo indica que, apesar de se ter usado indistintamente música popular e folclórica durante as primeiras décadas do século XX, surgiu, em meados do mesmo século, a necessidade de se usar duas palavras distintas para diferenciar a nova música urbana da música rural, identificando-se popular à primeira e folclórica à segunda. Essa proposta não se converteu em um consenso, pois as complexidades eram maiores, como se verá no capítulo seguinte.

Por outro lado, ficou claro que o folclore não caracterizou a música popular por seus elementos musicais, mas sim por parâmetros externos, e, em geral, os escritores latino-americanos não se preocuparam em distingui-la musicalmente. Ao que parece, Mário de Andrade compreendeu a música popular como uma soma de aspectos, e foi um dos poucos autores que juntou às particularidades psicológicas e sociais, algumas de cunho musical. Nesse sentido, é possível entender a razão pela qual Mário do Andrade atravessou os limites entre o campo e a cidade para juntar "sob o mesmo teto" seus fenômenos musicais, na medida em que nenhuma das características por ele propostas vincula-se ao ambiente em que a música foi criada ou usada.

Para essa amálgama urbano-rural, pode ter contado o fato de que, quando Mário do Andrade começou a escrever sobre música, a distância que existia entre a música camponesa, a música das cidades e a música gravada, era menor do que viria a ser uns anos depois. Parece que, na década de 1920, as sonoridades musicais não eram tão díspares, o que teria permitido a um intelectual tão meticuloso como Mário de Andrade que não hesitasse em selecionar gêneros de vários tipos e os colocasse sob a mesma epígrafe de música popular brasileira. Esse fato, porém, não impediu que, mais tarde, ele mesmo começasse a se sentir incomodado com a categoria criada, à medida que o meio musical foi mudando. Essas mudanças vividas pelo meio musical e suas repercussões no conceito de música popular durante as primeiras décadas do século XX serão o tema do terceiro capítulo. 


\section{"CARNE PARA ALIMENTO DE RÁDIOS E DISCOS". SONS DA CULTURA URBANA MODERNA E O CONCEITO DE MÚSICA POPULAR}

\section{1 "Os técnicos norte-americanos que vieram para cá se desnortearam": Mário de Andrade e os discos}

Ao que tudo indica, foi por volta do ano de 1927 ou 1928 que Mário de Andrade comprou seu primeiro gramofone e iniciou sua coleção de discos de $78 \mathrm{rpm}$. Com cerca de 35 anos, e próximo a sua consagração como literato e pesquisador musical, por meio de seus livros Macunaíma e Ensaio sobre a música brasileira, Mário de Andrade não pertencia à classe enriquecida de São Paulo, e o hábito de ouvir "música mecânica" em casa não era uma lembrança de infância. Talvez não seja por acaso que, em sua coleção de discos, as gravações mais antigas datem de 1927 e 1928 - embora as datas não coincidam com os números de organização que ele lhes atribuiu - e que suas primeiras menções públicas à música gravada sejam desses mesmos anos. Embora em 1924 ele tenha feito alusão ao aparelho reprodutor em um de seus poemas, foi somente quatro anos mais tarde que contou a seus leitores que fora convidado pela Casa Paul J. Christoph, distribuidora de discos Victor em São Paulo, para ouvir música e experimentar seus gramofones. Além disso, em fevereiro desse mesmo ano, escreveu seu primeiro artigo jornalístico dedicado ao fonógrafo e, em particular, na sua correspondência com Luciano Gallet, usou a expressão "música mecânica"1. Tudo parece indicar que, em finais da década de 1920, a fonografia era um tema que lhe interessava.

Possivelmente, essas menções à música gravada relacionam-se ao fato de que, nessa época, Mário de Andrade estava pensando em investir seu salário de professor do Conservatório para comprar uma vitrola e seus primeiros discos de 2004.

1 A música popular brasileira na vitrola de Mário de Andrade. São Paulo: SESC SENAC, 
acetato. Não seria casual que nosso autor tivesse decidido fazer esse investimento nessas datas se considerarmos que, em 1925, as casas discográficas Victor Talking Machine e Columbia Phonograph Company iniciaram as primeiras gravações elétricas e conseguiram demonstrar que a nova tecnologia dava maior fidelidade ao som de seus produtos. Foi justo em 1927 que a empresa discográfica alemã Odeon, principal sócia da casa Edison (1902-1932) no Rio de Janeiro, adotou esse mesmo mecanismo de gravação e que entraram no Brasil as primeiras gravações elétricas. Além disso, as mudanças tecnológicas e de mercado motivaram as companhias a baixar os preços de seus produtos. Talvez Mário de Andrade tenha-se deixado seduzir pela nova qualidade do som gravado e, em um dia de 1927 ou 1928, tenha saído de uma das lojas de gramofones com um desses aparelhos, algum disco Odeon ou Victor, que pertence à sua coleção, e o catálogo de 1927, em espanhol, de discos comercializados pela Victor Talking Machine.

Mário de Andrade abriu a porta de sua casa à música gravada. A partir desse momento, percebe-se que ela também começou a penetrar em seu conceito de música popular. Lenta e silenciosamente, parece que a música mecânica levou o intelectual paulistano a sentir a necessidade de modificar o conceito música popular, de ascendência romântica, para incluir aquela música de viés urbano e popular como a que circulou massivamente nos discos.

Em meados da década de 1920, no Brasil e em toda a América Latina, a reprodução do som por meio de gramofones ou fonógrafos não era uma realidade desconhecida. As ruas das capitais latino-americanas conheciam bastante bem esse som, pois desde inícios do século XX a nascente indústria discográfica norteamericana tinha posto seus olhos na gravação e comercialização da chamada foreing music. De acordo com William Kenney, desde o início da história da fonografia, houve interesse na música que se tocava no outro lado da fronteira americana, já que seus primeiros empresários, além de serem imigrantes europeus, reconheceram um mercado potencial nas massas migratórias. Antes da Primeira Guerra Mundial, Odeon, Columbia e Victor optaram por uma política de estímulo à nostalgia do velho país de origem por meio da venda de música folclórica, danças e hinos religiosos de seus países. Kenney observou que, em 1917, a chamada música forânea representou $75 \%$ das vendas, e que os catálogos das principais empresas ofereciam música 
gravada originaria de Santiago do Chile, Buenos Aires, Montevidéu, Lima, Rio de Janeiro, Bogotá, Trindade, Havana e Porto Rico, entre outros. Em 1926, esse mercado esteve dominado pela música mexicana, que era o maior grupo de imigrantes nos Estados Unidos ${ }^{2}$.

Também é sabido que essas mesmas empresas discográficas reconheceram um mercado potencial no circuito latino-americano. De acordo com Juan Pablo González, desde inícios do século XX já se realizavam gravações experimentais, em cilindros de cera, da música tocada em países como Brasil (desde 1897); Argentina (desde 1902), e México, Cuba e Chile (a partir de 1905). O êxito desses experimentos fez com que entrassem em território latino-americano os primeiros agentes americanos e europeus equipados com aparelhos de gravação portáteis. Esses agentes instalaram-se em hotéis locais e convidaram os músicos do lugar para gravar sua música. Depois, voltaram para seus estúdios nos Estados Unidos e Europa, fizeram milhares de cópias de algumas dessas gravações e devolveram-nas aos países de origem em forma de disco de $78 \mathrm{rpm}$, prontos para serem comprados pela população local.

Discos e aparelhos reprodutores foram vendidos em todas as capitais latinoamericanas das primeiras décadas do século XX. No Chile, há dados de importação de fonógrafos da década de 1890, depois que um dos representantes da Edison fizera uma excursão pela América do Sul mostrando o novo invento ${ }^{3}$. No caso colombiano, sabe-se que o primeiro gramofone foi ouvido em 1892, em uma pequena cidade chamada Bucaramanga, e que, entre 1915 e 1916, chegaram aos portos marítimos da costa caribenha colombiana 13 toneladas de fonógrafos e gramofones, equivalentes a cerca de 500 aparelhos ${ }^{4}$. Em 1889, Frederico Figner - fundador da Casa Edison no Rio de Janeiro - embarcou nos Estados Unidos com destino a Havana para fazer

2 Kenney, William Howland. "The Phonograph and the Evolution of «Foreign» and «Ethnic» Records." Recorded Music in American Life: the Phonograph and Popular Memory, 1890-1945, New York: Oxford University Press 1999.

3 González, Juan Pablo e Rolle, Claudio. Historia social de la música popular en Chile, 1890-1950. Santiago: Ediciones Universidad Católica de Chile, 2005, p. 179.

4 Bermúdez, Egberto. "Cien años de grabaciones comerciales de música colombiana. Los discos de «Pelón y Marín» (1908) y su contexto." Ensayos. Historia y teoría del arte. v. 17, (2009) p. 120 . 
exibições do fonógrafo em sessões com entradas pagas em vários países latinoamericanos, antes de se radicar no Brasil 5 .

O êxito comercial desse trabalho também se viu refletido na abertura de filiais das principais casas discográficas em países latino-americanos. De acordo com William Kenney, em 1904, a Columbia Gramophone abriu um estúdio de gravação no México e, no ano seguinte, a Victor Talking Machine fez o mesmo. Não obstante, é provável que não se tratassem de estúdios fixos, mas sim das primeiras viagens, conhecidas como recording trips, que os engenheiros destas duas empresas realizaram a esse país.

Seria possível pensar que, em 1927 e 1928, anos em que talvez Mário de Andrade tenha iniciado sua coleção de discos, já houvesse certa "tradição" na gravação de música latino-americana, pois quase três décadas antes tinham sido feitas as primeiras tentativas comerciais. Por exemplo, no Brasil, a Casa Edison instalara-se no Rio de Janeiro, e outros selos pequenos o fizeram em São Paulo e no Rio Grande do Sul. Na Argentina, entre 1913 e 1918 aproximadamente, foi aberta a Discos Nacional, como filial da Carl Lindström Company, uma das maiores empresas do momento. Além disso, depois da Primeira Guerra Mundial, patentes expiraram e foram criados outros selos menores, como Brunswick, Pathé, Emerson Gennett e Okeh, que também se interessaram pela comercialização da foreing music e entraram no mercado latino-americano. Em 1928, a Victor Talking Machine decidiu investir em filiais no Chile e no Brasil, motivada pelo êxito que, em 1921, tinha tido a abertura da filial argentina da Pan American Recording. Na década de 1930, tanto a Victor Talking Machine quanto a Columbia Phonograph Company, as duas maiores companhias do momento, associaram-se com empresas de cinema e de rádio, aumentando assim seus raios de influência.

Há que se dizer que existem vazios na historiografia latino-americana a respeito da história da fonografia, pois se trata de uma história complexa porque, além da documentação ser escassa e dispersa, suas dinâmicas criaram uma informação pouco explícita e facilmente contraditória que, na realidade, reflete o mundo ladino dos empresários internacionais e locais que procuraram lucrar com o

5 Franceschi, Humberto. Registro sonoro por meios mecânicos no Brasil. Rio de Janeiro: Studio HMF, 1984, p. 139. 
novo invento. Não obstante, tudo parece indicar que o Brasil foi um centro de comércio, gravação e elaboração de discos de grande importância na América do Sul durante as primeiras três décadas do século XX. Parte desse papel deveu-se aos trabalhos da Casa Edison, no Rio de Janeiro.

Seu dono, Frederico Figner, iniciou-se na venda de cilindros de cera e aparelhos reprodutores de música e, desde 1902, percebeu que o maior ganho estava na gravação e venda de música. Com base em seu tino de comerciante, aceitou a oferta feita por Frederick Prescott — ex-funcionário da Zono-phone e fundador da International Talking Machine e de seu selo Discos Odeon (1903) — de gravar música no Brasil, que seria prensada na Alemanha, para depois ser vendida por ele em sua loja da rua Ouvidor, no Rio de Janeiro. Figner também soube aproveitar a patente outorgada por Prescott para ser distribuidor exclusivo de discos gravados dos dois lados - uma novidade para a época - e tampouco desprezou a proposta que a International Talking Machine lhe fez, em 1913, quando fazia parte da Carl Lindström Company, de abrir uma fábrica para prensar seus discos e os de outras gravadoras no Rio de Janeiro.

Em um ambiente camaleônico, em que as associações comerciais, os nomes dos selos e o manejo das patentes transformavam-se à conveniência, consegue-se perceber que, além das atividades da Odeon através da Casa Edison, as outras grandes empresas discográficas europeias e norte-americanas não economizaram esforços para entrar no mercado brasileiro. Assim, desde cedo a Victor Talking Machine registrou sua marca, parece que através de Figner (1904). O mesmo foi feito pela Columbia (1911), deixando uma parte nas mãos da Casa Edison e outra nas mãos da Casa Standard, de A. Campos e CIA. Parece que The Gramophone Co. de Londres, outro dos gigantes da indústria, optou por fazer sua distribuição através da Casa Ao Bogary, de Arthur Augusto Villar Martins (s.f), antigo vendedor de cilindros de cera. Depois, a discos Brunswick encarregaria a Campessie e Camin, em São Paulo, da distribuição de seus discos (c.1923). Não obstante, parece que as datas dos registros oficiais não indicam a entrada exata no mercado brasileiro, mas sim a da sua legalização, pois também há indícios de comercialização anterior, além de registros sob nomes e distribuidores distintos. 
Os grandes lucros que a gravação e a venda de música geravam motivou outros comerciantes e empresários locais a abrirem seus próprios selos discográficos, como aconteceu com Discos Gaúcho (1913), de Saverino Leonetti, que também abriu sua própria fábrica de discos em Porto Alegre. São outros exemplos: Discos Popular (1920), de Paulo Lacombe e Juan Bautista Gonzaga, filho de Chiquinha Gonzaga e antigo funcionário da Casa Edison; Discos Phoenix (1914), de um irmão e um cunhado de Frederico Figner; além de outros selos mais que constam entre os selos dos colecionadores, mas dos quais não se tem maiores dados. Esse é o caso de Atlanta (sociedade entre Severino Leonetti e o argentino Alfredo Almendola), Imperador/Discos, Brasil Phone, Jumbo, Era, Arte-fone e as menções à Casa Faulhaber, distribuidora de discos Favorite — selo da Carl Lindström Company - e de sua marca Empório Musical do Brasil, o qual parece ter desenvolvido o selo Faulhaber, que contava com vários grupos musicais fixos desde a década de 1910.

Em princípios da década de 1930, depois da crise econômica mundial, as companhias discográficas eram conglomerados de homens de negócios que puseram suas esperanças de recuperação econômica em suas alianças comerciais e nos mercados latino-americanos e asiáticos. De acordo com Arnaldo Contier, no Brasil, durante a década de 1930, a música estrangeira teve um maior consumo pois, além de se conseguir no mercado discos com música de outros países, as gravações de música brasileira costumavam vir acompanhadas, do outro lado do disco, de um tema musical de fora. Com a revolução de 1930 e, particularmente, com o golpe de 1937, aumentou a circulação de música norte-americana, argentina, mexicana e caribenha, graças às políticas de boa vizinhança difundidas pelos Estados Unidos e abraçadas pelo governo de Getúlio Vargas 6 .

Tendo em conta o que foi mencionado anteriormente, não é estranho que as lojas de São Paulo e Rio de Janeiro, onde Mário de Andrade certamente comprou seus discos, oferecessem uma ampla variedade de selos discográficos e repertórios a seus clientes. Sua coleção não se limitou a música brasileira ou erudita, mas incluiu gêneros norte-americanos, argentinos, mexicanos e cubanos, dos quais se destaca uma coleção do famoso Trio Matamoros (de Cuba) e de jazz norte-americano, além

6 "Nos fins dos anos 30 e inícios dos 40, o Brasil era visto como o paraíso dos cantores mexicanos" (Contier. Brasil Novo. Música, nação e modernidade: os anos 20 e 30. p. 302). 
de discos com música da Bolívia, Colômbia, Haiti, Paraguai e música oriental. Embora seja certo que uma parte dos discos que formaram sua coleção tenham sido comprados por seu dono, outros foram dados de presente pela Victor Talking Machine, provavelmente por intermédio de seu amigo Paulo Ribeiro de Magalhães, que trabalhava na empresa em São Paulo e, a partir de 1931, no Rio de Janeiro. Com um total aproximado de 540 discos, Mário de Andrade esclareceu que "pouco mais de 250 " foram-lhe doados pela Victor ${ }^{7}$.

Se Mário do Andrade comprou seu gramofone em finais da década de 1920, seria plausível a observação de Flavia Camargo Toni em relação ao crescimento acelerado de sua coleção na década de 1930. De acordo com a autora, esse investimento foi motivado pela decisão de Mário de Andrade de incluir referências discográficas em seus trabalhos escritos, como efetivamente fez em seu artigo "A música no Brasil" (1931) — escrito para a revista Anglo Brazilian Chronicle - e na segunda edição do Compêndio da história da música (1933), em que adicionou gravações discográficas comentadas ao final de cada capítulo, que foram omitidas nas edições seguintes. Dessa maneira, Mário de Andrade pôs em prática um dos "usos imperiosos" que qualquer professor de história musical, estética ou instrumental devia dar à nova tecnologia do disco: ilustrar, exemplificar e citar a discografia com fins pedagógicos ${ }^{8}$.

Francisco Curt Lange tinha uma opinião semelhante. Em 1934, escreveu a respeito da utilidade dos discos para trabalhos pedagógicos. Não obstante, nesse escrito, Lange não advogava pelo uso dos discos para ilustrar um escrito, mas sim para formar o caráter musical das crianças que ouviam rádio e "preparar el estado del alma que facilite la asimilación de determinada obra"9. Com esse propósito, Lange discorreu a respeito do tipo de repertório que devia ser privilegiado e suas vantagens $^{10}$.

\footnotetext{
${ }^{7}$ Arquivo do Instituto de Estudos Brasileiros. Catálogo Discos Mário de Andrade. Instituto de Estudos Brasileiros IEB-USP, Disponível em www.ieb.usp.br/catalogo\%5Feletronico (9 dez. 2011).

8 Andrade, Mário de. "Discos e fonógrafos." [1928] In: Flávia Camargo Toni (ed.), A música popular brasileira na vitrola de Mário de Andrade, São Paulo: SESC, SENAC, 2004.

${ }^{9}$ Lange. "Fonografía pedagógica." p. 169.

${ }^{10}$ Ibid., p. 158.
} 
Outra das particularidades da coleção de discos de Mário de Andrade é que cerca de $70 \%$ das capas dos discos têm alguma anotação feita à mão por seu dono. De acordo com Flavia Camargo Toni, parece que em meados de 1935, Mário de Andrade substituiu as capas originais por capas de cartolina branca com o fim de escrever sobre elas observações relacionadas com o conteúdo do disco. Por este motivo, constam, nas capas atuais, um número de série para a organização, o nome da empresa discográfica (em abreviatura) e o número do disco. O mais interessante dessas capas é que, em algumas delas, de forma adicional, Mário de Andrade escreveu observações curtas a respeito do conteúdo musical, provavelmente depois de uma audição cuidadosa. Graças a esse recurso, é possível conhecer algumas das mais íntimas impressões que esses discos causaram-lhe e, além disso, cruzar os comentários com seus trabalhos publicados em que menciona a música, o gênero, o compositor ou intérprete da gravação.

Essas capas com espaço em branco para fazer anotações indicam que, para Mário de Andrade, a fonografia tinha uma função que ultrapassava os fins de mero entretenimento, embora a publicidade da época focalizasse essa finalidade. Para ele, esses registros, além de ajudar a preservar a música e de facilitar sua exemplificação em trabalhos pedagógicos, também eram material útil para a pesquisa musical, e ele quis valer-se deles para se aprofundar em temas de seu interesse. Essa manipulação e escuta cuidadosa do material discográfico talvez tenha "cutucado" seu conceito de música popular e o levado, no final de seus dias, a pequenas mas significativas mudanças em seu vocabulário, como é o caso do uso da palavra popularesco para denominar, possivelmente, a música que era intermediária entre o popular folclórico e o erudito, como se verá adiante, no presente capítulo.

A utilidade que Mário de Andrade deu aos discos como material de estudo fica evidente no artigo "A pronúncia cantada e o problema do nasal brasileiro através dos discos" (1937), em que se serve da análise das vozes gravadas por vários tipos de cantores para identificar as particularidades fonéticas do português do Brasil. Como bom ex-aluno de canto e conhecedor das dificuldades da técnica vocal e do bel canto, o intelectual usou seus discos como fonte para um estudo da fala de seu país e, além 
disso, para ajudar na interpretação correta da música vocal brasileira ${ }^{11}$. De acordo com uns apontamentos manuscritos - provavelmente anteriores ao artigo mencionado - Mário de Andrade referiu-se a alguns dos cuidados a ter com o uso da discografia para tal tema:

[...] O caráter vocal é sempre uma deformação. Ou rege a instrução do cantor erudito as leis do belcanto que é europea e erudita mesmo da Europa ou é imitação da voz popular (Stefana, Mota da Mota). Ora talvez esta imitação ainda seja mais desnorteadora que o belcanto, porque é uma verdadeira caricatura. O cantor exagera processos (vogal, vocalização, cacoetes de emissão) para forçar a comparação e aparência de semelhança. Em discografia pode-se mesmo lançar o aforismo de que «nada ha de mais dissemelhante ao original que a sua imitação» ${ }^{12}$.

Todos os discos citados no artigo supracitado encontram-se em sua coleção discográfica, e chamou a atenção o fato de que as observações escritas em suas capas nem sempre se relacionavam com o problema da fonética do português. Por exemplo, no artigo, Mário de Andrade escreveu a respeito da pronúncia de Mário Reis no samba $O$ que há contigo, que o cantor tinha exagerado a pronúncia "buscando familirizá-la, mas na verdade, viciando-a bastante"13. A capa desse disco traz a seguinte anotação: “O samba de Donga é um modelo no gênero e está orquestralmente bem realizado"14. Parece que, em um momento de escuta diferente ao realizado para a escritura do artigo, Mário de Andrade fixou-se em outros aspectos da peça de Ernesto dos Santos (Donga) e fez um comentário positivo acerca daquela gravação $(\text { faixa } 3)^{15}$.

Casos como esse indicariam que Mário de Andrade encontrou nos discos um material rico que podia ser aproveitado em diversos temas, graças à sua capacidade de ouvir as produções discográficas tendo como pano de fundo um conjunto de aspectos que podiam ser separados e analisados. Essa escuta variada gerou a

11 Andrade, Mário de. "A pronúncia cantada e o problema do nasal brasileiro através dos discos." [1938] In: Oneyda Alvarenga (ed.), Aspectos da música brasileira, Belo Horizonte, Rio de Janeiro: Villa Rica Editoras Reunidas Ltda, 1991.

${ }^{12}$ Andrade, Mario de. O disco popular no Brasil. Fundo Mário de Andrade, Série Manuscritos, São Paulo: Aquivo do Instituto de Estudos Brasileiros (IEB - USP). Caixa 057, MA-MMA-040, s.d.

O manuscrito está escrito sobre folhas de papel verde, as quais foram usadas por Mário de Andrade entre 1933 e 1935, conforme informa-se no projeto Estudo do processo de criação de Mário de Andrade nos manuscritos de seu arquivo, em sua correspondência, em sua marginália e em suas leituras (2007-2010) sob coordenação de Telê Ancona Lopez.

${ }^{13}$ Andrade. "A pronúncia cantada e o problema do nasal brasileiro através dos discos." [1938] Aspectos da música brasileira, p. 102.

${ }^{14}$ Arquivo do Instituto de Estudos Brasileiros. Catálogo Discos Mário de Andrade.

15 O que há contigo. Samba interpretado por Mário Reis, discos Odeon No10569, de autoria de Ernesto do Santos (Donga), gravado em 1930. 
sensação de que a sua posição diante da maioria das produções era ambígua pois, de uma mesma gravação, podia ressaltar aspectos positivos e negativos sem que isso significasse o rechaço ou a glorificação total da produção.

Como é sabido, o mais claro exemplo da utilidade do disco como meio de conservação e divulgação da música ficou associado às funções desempenhadas por Mário de Andrade como diretor do Departamento de Cultura. Uma das primeiras coisas que fez em seu cargo foi comprar um dos mais modernos aparelhos de gravação, que seria usado dois anos depois pela Missão de Pesquisas Folclóricas. Sabe-se que, entre os objetivos da Missão, estava precisamente o de usar essa tecnologia para "imortalizar” a música folclórica. Além disso, pela importância que tinha para ele a reunião, organização e disposição da música gravada, encarregou-se de criar uma instituição pública dedicada a esse fim.

Em 1928, Mário de Andrade havia mencionado brevemente a convicção da importância dos discos ao celebrar a iniciativa do governo italiano na formação da Discoteca do Estado ${ }^{16}$. Em 1935, por meio de correspondência com Francisco Curt Lange, que trabalhava na Discoteca Nacional Uruguaia, pediu-lhe conselho a respeito de um modelo de organização de uma discoteca pública, recebendo então um dos escritos de Lange sobre "a mecanização da música" na rádio ${ }^{17}$. É provável que com este material e outro mais Mário de Andrade tenha escrito o projeto que apresentaria pouco depois com o propósito de fundar a Discoteca Pública Nacional. De acordo com Flavia Camargo Toni, o musicólogo usou os catálogos discográficos que foram conservados em sua biblioteca para assinalar parte da discografia que compraria para a nova instituição ${ }^{18}$.

Por outro lado, em que pese o fato de a coleção de discos do musicólogo brasileiro possuir uma variedade musical que surpreenderia quem considerou que ele só se interessou pela música erudita e folclórica, não se pode afirmar que sua formação seja resultado dos interesses variados de seu dono posto que, nela, as doações da Victor têm uma alta representatividade. Vista hoje em dia, chamaria a

\footnotetext{
Andrade.

16 Andrade. "O fonógrafo." [1928] A música popular brasileira na vitrola de Mário de

${ }^{17}$ Lange. "La mecanización de la musica y la supersaturación musical.".

${ }^{18}$ A música popular brasileira na vitrola de Mário de Andrade. p. 44.
} 
atenção o grande número de gravações de música que se costuma chamar de música popular, e que pouco tem a ver com a música camponesa que o folclore ${ }^{19}$.

Em uma tentativa de relacionar a coleção de discos de Mário de Andrade á música que circulava pelas ruas de São Paulo, algumas pistas podem ser encontradas ao se vincular seus discos com as resenhas jornalísticas acerca da música mais consumida naquele tempo. De acordo com Camila Koshiba, em 1928, uma nota do Jornal Nacional dizia que os discos nacionais mais procurados pelos compradores eram os interpretados por Chico Viola, Gastão Formenti, Vicente e Pedro Celestino e Stefana de Macedo, principalmente quando cantavam composições de Hekel Tavares, Joubert de Carvalho e Marcelo Tupinambá ${ }^{20}$. Na coleção de discos de Mário de Andrade repousam exemplares de discos dos quais esses intérpretes e compositores participaram: são quatro discos interpretados por Gastão Formenti e quatro por Stefana de Macedo, que, por sua vez, mereceu alguns parágrafos por parte de Mário de Andrade em seu escrito a respeito da pronúncia do português. Também estão lá cinco discos com composições de Hekel Tavares (uma deles, $O$ sapo dourado, dedicado a Mário de Andrade), três discos com peças de Joubert de Carvalho e quatro de Marcelo Tupinambá, cujo apreço por parte do musicólogo é conhecido $^{21}$. Além disso, há gravações de músicos como Aracy de Almeida, Ary Barroso, Carmem Miranda, Donga, Francisco Alves, João de Barro, Noel Rosa, Sinhô e Pixinguinha, entre outros. É difícil afirmar que Mário de Andrade tenha deixado passar desapercebido o fenômeno da música popular urbana comercializada por meio dos discos, posto que ao menos alguns daqueles trabalhos foram ouvidos pelo musicólogo em sua vitrola, como se sabe.

Na década de 1940, as coisas mudaram para Mário de Andrade após sua saída abrupta do Departamento de Cultura e sua decisão de ir morar no Rio de Janeiro: parece que o escritor caiu em uma depressão que o levou ao abandono da

19 O catálogo provisório feito pelo Arquivo do IEB arrola um total de 481 registros de música popular brasileira e 476 de música popular estrangeira, em contraposição, por exemplo, a 108 de música folclórica brasileira, 15 registros de música erudita brasileira e 387 de música erudita estrangeira.

${ }^{20}$ Diário Nacional. “A discomania em São Paulo” 4 agosto 1928, p.5 Apud. Gonçalves, Camila Koshiba. Música em 78 rotações: "Discos a todos os preços» na São Paulo dos anos 30. (Dissertação) Universidade de São Paulo, 2006, p. 68.

${ }^{21}$ Andrade. "Marcelo Tupinambá." [1924] Música, doce música. Estudos da crítica e folclore, e Andrade, Mário de. "Marcelo Tupinambá." Diário Nacional, 25 ago. 1927. 
escuta de discos. Em 1940, em carta a Oneyda Alvarenga, ele contou que "[...] Nem sei os discos que tenho aqui! Minha vida se passa tão desgostosa que quando trouxe os discos ainda ouvia alguns, depois nunca mais ouvi nada $[\ldots]^{22}$ ". Sabe-se que, pouco tempo depois, Mário de Andrade decidiu mandar sua vitrola de volta para São Paulo, para sua antiga casa.

Embora os escritos publicados de Mário de Andrade não se referissem diretamente à discografia de sua época como fenômeno em si, conta-se com um curto manuscrito inacabado, cujo título reza $O$ disco e a música popular no Brasil, cuja emenda no título parece indicar que começou como um texto que relacionaria os discos com a música popular, mas que, em certo momento, seu autor preferiu adjetivar como populares os próprios discos, como se se tentasse referir a uma popularização do disco. Nesse manuscrito, elaborado provavelmente em meados da década de 1930, nosso autor parece que se havia proposto a criar uma argumentação em torno do tema da discografia brasileira que pudesse servir como justificação ou motivação para a criação da Discoteca Pública.

O manuscrito indica que Mário de Andrade planejava apresentar o tema dividido em quatro aspectos principais: (i) a utilidade do disco na pesquisa folclórica; (ii) o conceito comercial que existia na discografia popular; (iii) a existência de um sentimento pejorativo em relação à América do Sul, causado pelo controle do comércio discográfico por empresas estrangeiras e pelo pouco conhecimento que se tinha do folclore; (iv) o valor "científico" dos discos. Com isso, pretendia posicionar a criação da Discoteca como uma necessidade de primeira ordem ${ }^{23}$.

De acordo com o manuscrito e com a relação que possivelmente Mário do Andrade teve com os discos de seu meio, intui-se que, ao escrever esse esboço, o autor percebia que estavam circulando dois tipos de música popular nas gravações discográficas. Talvez, uma que lhe era familiar porque provinha das tradições musicais camponesas e étnicas, que ele e pesquisadores do folclore vinham estudando, e que chamavam música folclórica ou popular. A outra, possivelmente, tinha outro tipo de sonoridade, uma sonoridade parcialmente nova, que Mário de Andrade reconhecia como um tipo de música banhada com uma atmosfera estranha,

${ }^{22}$ A música popular brasileira na vitrola de Mário de Andrade. p. 48.

${ }^{23}$ Andrade, O disco popular no Brasil. 
relacionada com os fins comerciais das empresas discográficas, e que também era chamada de música popular.

Das notas deixadas nesse manuscrito e dos comentários feitos em textos publicados, pode-se deduzir que, para Mário de Andrade, era preciso distinguir em duas categorias os discos de música popular brasileira: comerciais e científicos. De forma clara e repetida, nosso autor chamou a atenção para a importância que tinha, para o trabalho etnográfico, a possibilidade de se gravar a música e reproduzi-la sem que os sons mudassem drasticamente, de modo que o pesquisador pudesse estudá-la em seu gabinete. Esses seriam os discos de caráter científico, quer dizer, aqueles que reproduziam a música popular o mais próximo possível de como era tocada em seu contexto. Por esse motivo, eles eram uma ferramenta fundamental pois, além disso, era claro para Andrade que a música era um fenômeno volátil e complexo do qual a grafia ocidental não conseguia dar conta.

As notas de aquele manuscrito pareciam indicar que um exemplo de discos de valor científico seria o das 11 gravações feitas pelo pesquisador alemão Eric von Hornbostel, lançadas em 1931 pela Odeon e Parlophone. A coleção oferecia a seus compradores música tradicional do Japão, China, Java, Bali, Sião, Índia, Indochina, Tunísia, Egito e Pérsia, e vinha acompanhada de um folheto explicativo ${ }^{24}$. Nas capas dos discos de Mário de Andrade, há comentários entusiasmados, como "Java é uma maravilha" ou "Bali maravilhosa Sião (sic)" 25 . Provavelmente, sua ideia de que o disco servia como base para o estudo da música popular era confirmado pelo trabalho realizado por E. von Hornbostel, um dos mais famosos pesquisadores musicais e pioneiro do que, algumas décadas depois, receberá o nome de etnomusicologia.

Além disso, com o adjetivo "científico", foram denominados alguns dos discos de música brasileira de sua coleção, como é o caso da peça Toada de mutirão, com autor desconhecido ( $\delta$ faixa 4$)^{26}$, e Folia de Reis, de Angelino de Oliveira,

24 Porter, James. "Documentary Recordings in Ethnomusicology: Theoretical and Methodological problems." Association for Recorded Sound Collections - Jornal, v. 4, n. 2 (1974), Disponível em <http://www.arsc-audio.org/journals/v6/v06n2p3-16.pdf>.

${ }^{25}$ Arquivo do Instituto de Estudos Brasileiros. Catálogo Discos Mário de Andrade.

26 Toada de mutirão, interpretado por Cornélio Pires com Zé Messias e Parceiros, discos Columbia N²0033, gravado em 1930. 
interpretada por Cornélio Pires, Maracajá e Os bandeirantes em $1930(\delta \text { faixa 5 })^{27}$. Na capa do último disco, lê-se:

Um dos poucos discos folcloricamente científicos que possuímos, afora as Modas caipiras. A Folia é absolutamente sem influência ou arranjo. Por azar, não havia no agrupamento orquestral desta Folia, o triângulo, o 'ferrinho' como eles dizem, lembrando Portugal, que é obrigatória das orquestrinhas das Folias, conforme me informou o próprio Cornélio Pires ${ }^{28}$.

Por outro lado, Mário de Andrade reconhecia que existiam outros discos de música popular que eram produzidos com o fim de agradar e ser vendidos rapidamente, discos que não se preocupavam em registrar fielmente as tradições musicais, mas que acomodavam os gêneros populares a outras circunstâncias, como as particularidades técnicas do processo de gravação, o orçamento disponível para o pagamento de músicos ou qualquer outro parâmetro alheio a um interesse "científico". De acordo com o segundo ponto enunciado no manuscrito, parece que Mário de Andrade atribuía essa circunstância ao desconhecimento das tradições musicais populares do Brasil e a um certo menosprezo das empresas estrangeiras por elas. Essas duas particularidades seriam as causas de as gravações comerciais transformarem os elementos musicais tradicionais sem os critérios apropriados.

Talvez, na opinião do autor, a existência desses dois tipos de discos de música popular - científicos e comerciais - não impedia de usar cientificamente alguns dos produtos comerciais das empresas fonográficas estrangeiras. No item 4 o que foi mais desenvolvido - parece que Mário de Andrade ia escrever a respeito de três tipos de gravações que, mesmo tendo sido feitas sem critérios científicos, podiam ser usadas honestamente pelo pesquisador musical.

Essa circunstância dava-se com os discos que reproduziam gêneros como a moda caipira, alguns de feitiçaria carioca ou relacionados com a música da África pois, segundo o esquema mencionado, esses eram gêneros "infensos à influencia universalista das cidades" 29 , conforme parece demonstrar o disco Odeon com os

27 Folia de Reis, interpretado por Cornelio Pires e Foliões de Zé Messias, discos Columbia No20032, de autoria de Angelino de Oliveria, gravado em 1930.

${ }^{28}$ Ibid.

${ }^{29}$ Andrade, Mario de. O disco popular no Brasil. Fundo Mário de Andrade, São Paulo: Aquivo do Instituto de Estudos Brasileiros (IEB - USP). Caixa 057, MA-MMA-040, s.d.

É interessante lembrar que Mário do Andrade fez várias notas a respeito das modas, modinhas e toadas de viola difundidas pela fonografia. De acordo com Camila Gonçalves Koshiba, parece que o musicólogo ia estudar o material em um escrito sobre a música paulista (Gonçalves. Música em 78 rotações: «Discos a todos os preços» na São Paulo dos anos 30. pp. 146, 165 e ss). 
cantos de Echu e Ogum, em interpretação do Conjunto Africano e Getúlio Marinho $(\boldsymbol{f} \text { faixas } 6 \text { e } 7)^{30}$, em cuja capa o escritor paulista apontou: "Disco ótimo. De originalidade formidável. Parece científicamente perfeito"31.

Também podiam ser usados para estudo musicológico os discos de gêneros nascidos da "influência universalista das cidades", como era o caso do choro e do maxixe no Brasil, e do huayno na Bolívia ${ }^{32}$, representados nos discos de sua coleção, com os huaynos Amorosa palomita e Delícias del Inca, interpretados por Felipe V. Rivera e sua Orquestra típica boliviana ${ }^{33}$, ou os choros Carinhoso, de Pixinguinha, e Suspiros, de Gerald Desmond, gravados pela discos Victor em 1929 (“Choros muito bons. Alfredo Vianna é Pixinguinha $\left.{ }^{34 "}\right)(\delta \text { faixa } 8 \text { e } 9)^{35}$.

O terceiro caso, no qual parece que os interesse do disco comercial coincidiriam com os interesses científicos, não está claro na redação do manuscrito. Talvez Mário de Andrade quisesse advertir que, em geral, os discos comerciais mantinham as características rítmico-melódicas da expressão popular, mas modificavam seu acompanhamento, instrumentação e caráter vocal. Portanto, o pesquisador poderia estudar somente os elementos rítmico-melódicos dos discos comerciais como elementos legítimos das tradições populares.

Ao que parece, Mário do Andrade não estava equivocado ao identificar que a melodia e o ritmo da música popular gravada eram o que, com maior frequência, mantinha-se sem modificações. Segundo William Howland Kenney, na primeira década do século XX, nos Estados Unidos, quando a indústria fonográfica iniciou as gravações da chamada foreing music, os empresário notaram que no mercado de seu

30 Canto de Echu. Macumba interpretada por Getúlio Marinho e Conjunto africano, discos Odeon $N^{\circ} 10690$, de autoria de Elói Antero Dias, gravado em 1931.

Canto de Ogum. Macumba interpretada por Getúlio Marinho e Conjunto africano, discos Odeon Nº10690, de autoria de Elói Antero Dias, gravado em 1931.

${ }^{31}$ Arquivo do Instituto de Estudos Brasileiros. Catálogo Discos Mário de Andrade.

32 Segundo o manuscrito, Mário de Andrade propunha-se a exemplificar esse caso com a rumba e sua transformação em fox-trot, usando como exemplo duas gravações de El Manicero, existentes em sua coleção, uma interpretada pelo Trio Matamoros e outra por Antonio Machin, Don Azpiazú e sua orquestra Cassino Havana.

${ }^{33}$ Discos Victor No 47682 . Ibid.

34 Ibid.

35 Carinhoso. Choro orquestral interpretado por Orquestra Victor Brasileira, discos Victor №33209, de autoria de Alfredo da Rocha Vianna (Pixinguinha) e João de Barro (Braguinha), gravado em 1929.

Suspiros. Choro orquestral interpretado por Orquestra Victor Brasileira, discos Victor Nº33209, de autoria de Gerald Desmond, gravado em 1929. 
país, os adjetivos de fora e imigrante eram assimilados a situações de pobreza e sujeira. Assim, os discos de foreing music não agradavam à maior parte dos consumidores em potencial. Para eludir essa situação, as casas de discos apresentaram a música estrangeira em um formato mais "limpo", e os gêneros folclóricos foram interpretados nas gravações por artistas de concerto e de ópera. Essa estratégia criou uma "síntese entre música pouco culta e interpretações eruditas", propiciando uma sonoridade simbiótica a algumas das peças musicais populares que se escutava nos discos. No caso das gravações de música étnica que não puderam ser vendidas a grupos de imigrantes, nem se consolidaram como mercados significativos em seus lugares de origem, elas foram comercializadas como "fotografias sonoras" exóticas.

Após a Primeira Guerra Mundial, as companhias discográficas norteamericanas abandonaram o adjetivo foreing e preferiram chamar a música de outros países simplesmente de música típica. Pela mesma época, iniciou-se a regravação da música popular americana nos idiomas mais falados pelos imigrantes, além da produção da chamada música típica em traduções para o inglês. Este foi o primeiro passo para que as companhias descobrissem o êxito comercial da apropriação de repertórios típicos e sua apresentação em arranjos com instrumentação e idioma norte-americano. "A linguagem levava um forte poder cultural, mas o conteúdo da aparência comercial e a música nas gravações não reconhecia a diversidade cultural" 36 .

Por meio desse processo, a música folclórica forânea que era gravada nos Estados Unidos perdeu muitas de suas características musicais, instrumentais e linguísticas. Desse tipo de fusão e seus resultados, é ilustrativa a peça de Julio Cañar, Sonhando en mi rondador, gravada em Nova Iorque para os discos Columbia e classificada como fox-trot-incaico ( $\delta$ faixa 10). Ali, ouve-se uma clara fusão da música tradicional da cordilheira dos Andes peruana e boliviana com a orquestração e interpretação da música de baile das cidades norte-americanas ${ }^{37}$.

36 Tradução nossa. Kenney. "The Phonograph and the Evolution of «Foreign» and «Ethnic» Records." Recorded Music in American Life: the Phonograph and Popular Memory, 1890-1945, p. $84 .$.

37 Soñando en mi rondador. Fox-incaico interpretado por Orquestra Terig Tucci, discos Columbia No5459X, de autoria de Julio Cañar gravado em 1936 em Nova Iorque. 
Ao que tudo indica, a caracterização da foreing music proposta pelo historiador William Kenney coincide, em termos gerais, com as notas manuscritas elaboradas por Mário do Andrade a respeito da música popular gravada. Embora acerca deste tema só se conheça o manuscrito citado anteriormente, as diversas observações semeadas por Andrade em outros escritos permitem imaginar que ele pensasse o fenômeno discográfico em termos mais ou menos similares aos enunciados por Kenney em data recente. O ouvido do escritor brasileiro foi sensível a algumas das transformações musicais que se estavam produzindo.

Não obstante, em certas ocasiões, Mário de Andrade manifestou publicamente críticas à música vendida em discos pois, embora desse mostras de ter um critério eclético, nem sempre aprovou o trabalho das casas discográficas. Em seus artigos, não atacou gravações pontuais, mas fez afirmações gerais - e uma particularmente agressiva - que deixaram clara a sua desaprovação em relação a um certo tipo de música. Um exemplo dessa postura é sua conhecida frase: "Trata-se exatamente de uma submúsica, carne para alimento de rádios e discos, elementos de namoro e interesse comercial, com que fábricas, empresas e cantores se sustentam" 38 , usada para qualificar como submúsica as canções lançadas para o carnaval carioca de 1939.

Uma pista sugestiva do som que tinha essa submúsica encontra-se em sua coleção de discos. A capa do disco em que foi gravado o samba Mulambo, em interpretação de Sílvio Caldas ${ }^{39}$, tem a seguinte anotação: “[...] coisas como estas que aliás são ótimas pra quando precisar citar porcarias absolutas"40 ( $\int$ faixa 11). Ao se ouvir o exemplo, não são evidentes os defeitos que desgostaram o escritor, mas dá para supor que estivessem relacionados com o uso de fórmulas rítmicas, harmônicas e formais, comuns à música gravada da época. Estando de acordo com o que nove anos depois Mário de Andrade chamará de submúsica e sua desaprovação do uso de fórmulas bem-sucedidas para ganhar o "aplauso fácil", talvez Mulambo tenha sido um samba que coubesse nessa categoria.

\footnotetext{
281.

38 Andrade. "Música popular." [1939] Música, doce música. Estudos da crítica e folclore, p.

39 Mulambo. Samba interpretado por Silvio Caldas, discos Victor No33301, de autoria de Carlos Cardoso, gravado em 1930.

${ }^{40}$ Arquivo do Instituto de Estudos Brasileiros. Catálogo Discos Mário de Andrade.
} 
Por outro lado, nota-se que Mário de Andrade compreendeu que o gerador de um bom produto discográfico não era só a qualidade da música, mas também a conjugação do musical com o técnico, pois ele tinha consciência de que a produção de um disco exigia mais do que intérpretes bons.

Ao contrário, em sua época eram mais comuns observações como a feita na revista Phono-Arte, pouco depois que a Victor e a Brunswick fizeram seus primeiros lançamentos de discos feitos no Brasil. A revista chamou a atenção para a qualidade das gravações de música brasileira sem se deter nas particularidades técnicas, mas destacando a visível baixa qualidade dos músicos diante dos microfones e os erros de afinação e ritmo ${ }^{41}$.

Em 1930, quando - ao que tudo indica — Mário de Andrade encontrava-se comprando, ouvindo e analisando uma ampla porção de discos, escreveu:

Da discação internacional, escapa do ruim talvez uns trinta-por-cento. Está claro que não falo como fabricação, que essa em algumas fábricas, Brunswick, Victor, Gramophone, a maioria das vezes é esplêndida. Falo da música que essas mesmas fábricas nos dão ${ }^{42}$.

No ano seguinte, particularmente em relação às gravações da música popular brasileira, Andrade tentou explicar, com uma dose de ironia, que as particularidades dos gêneros populares brasileiros tinham apresentado dificuldades aos técnicos da Victor, e que seus discos nem sempre eram o esperado:

A fábrica Victor tem hesitado e mesmo errado bastante nas suas gravações brasileiras. Diante de sonoridades novas, de processos novos de cantar, era natural, os técnicos norte-americanos que vieram para cá se desnortearam. Muitos foram os insucessos, em principal pela má disposição dos instrumentos ante o microfone. Especialmente nas cantigas e danças como viola, só ultimamente, ao cantar do delicioso piracicabano Zico Dias, é que a fábrica Victor conseguiu algum equilíbrio e discos bons ${ }^{43}$.

41 “...ignorantes das cousas musicais, falhos de afinação, noção de rythmo, sem ensaio ou necessitando de um estudo apropriado de canto ou puramente instrumental. É preciso, pois educal-os, ensaial-os, bumil-os afim de se poderem apresentar dignamente deante do rigoroso microphone, o qual evidencia de forma avassaladora todas as falhas existentes." (Phono-Arte. N. 32, 30/11/1929, p.2. Apud, Bessa, Virgínia de Almeida. "Um bocadinho de cada coisa»: trajetória e obra de Pixinguinha. História e música popular no Brasil dos anos 20 e 30. (Dissertação) Universidade de São Paulo, 2005, p. 143).

42 Andrade, Mário de. "Gravação nacional." [1930] In: Telé Ancona Lopez (ed.), Taxi e crônicas no Diário nacional, São Paulo: Duas Cidades. Secretaria da Cultura, Ciência e Tecnologia, 1976 , p. 236

43 Andrade. "Carnaval tá aí." [1931] Taxi e Crônicas no Diário Nacional, p. 322.

De acordo com Camila Koshiba, parece que Mário de Andrade conhecia de perto o trabalho musical de Zico Dias, e se presume que o músico caipira trabalhou na Victor por intervenção do escritor paulistano (Gonçalves. Música em 78 rotações: "Discos a todos os preços» na São Paulo dos anos 30. p. 166). 
Ao se referir aos "técnicos norte-americanos", provavelmente tentou diferenciar suas gravações das que estavam sendo feitas localmente por selos brasileiros. Segundo o que se observa nas notas de seus discos, Mário de Andrade comprou e ouviu com atenção seis dos discos do pequeno selo discográfico paulistano Arte-fone e parece que gostou de suas gravações. Provavelmente, ali encontrou o som da música popular que lhe era familiar, enquanto que, nos discos vendidos pelas grandes companhias, encontrou esse outro e novo tipo de música popular, a qual mantinha "um pé" no tradicional e outro no internacional.

Segundo o manuscrito inacabado Discoteca nacional, conservado em seu arquivo, parece que nosso autor não rechaçava a produção discográfica simplesmente por ser comercial, mas entendia que ao ser esse o critério principal, seus produtos não eram uma fotografia que representasse a complexidade e variedade musical de seu país, mas somente uma parte dela, ou seja: a música urbana.

A formidável coleção de discos brasileiros, produzida pelas diversas fábricas particulares, é exclusivamente feita por interesses comerciais. Assim, é impossível, por intermédio duma discoteca, dar uma idéia legítima, científica, do que seja a música nacional do povo brasileiro.

Antes de mais nada, a discografia comercial é urbana como produção e finalidade, se utiliza de cantores e instrumentistas citadinos que lhe permitem menos despêsa, e procura servir ao freguês da cidade que the causa maior lucro. Ora o folclore é demasiadamente delicado e tímido para conservar nos grandes centros populosos a sua pureza e originalidade nativas ${ }^{44}$.

A clareza com a qual ele parece ter entendido a relação disco/comércio não parece ter sido conhecida por seus leitores, pois não foi encontrada uma apreciação concreta acerca desse tema em seus textos publicados. Entretanto, em seu arquivo, além do manuscrito citado, existem notas dispersas que falam da atenção que Mário de Andrade prestou à venda de música, como é o caso da observação: "O disco de maior venda, vinte mil saidos, em janeiro de 1931..."45 na capa do samba-canção Mamãe não quer, na voz de Carmen Miranda $(\delta \text { faixa } 12)^{46}$. Documentos como esse servem para complexifizar os labirintos do pensamento do musicólogo brasileiro e seu possível conceito de música popular, em sintonia com a música comercial.

\footnotetext{
${ }^{44}$ Andrade, Mário de. Discoteca nacional. Fundo Mário de Andrade, Série Manuscritos, São Paulo: Arquivo Instituto de Estudos Brasileiros (IEB-USP). Caixa 058, MA-MMA-042, s.d.

${ }^{45}$ Arquivo do Instituto de Estudos Brasileiros. Catálogo Discos Mário de Andrade.

46 Mamãe não quer. Samba-canção interpretado por Carmen Miranda e Choro Victor, discos Victor N³3263, de autoria de Américo de Carvalho, gravado em 1930.
} 
Ao que tudo indica, os leitores de Mário de Andrade conheceram melhor, e tiveram mais em conta, suas opiniões a respeito da música gravada como música de "uma mediocridade desolante", afirmação feita em 1931 no Diário Nacional. O curioso é que, junto a essa apreciação, o autor também ressaltou exemplos de música popular de boa qualidade, como "três discos de valor artístico e excepcional": Nego Bamba $\left(\delta\right.$ faixa 13) ${ }^{47}$, Desgraça pouca é bobage ${ }^{48}$ e São Benedito é ôro só $(\delta$ faixa 14) ${ }^{49}$. Provavelmente, esse tipo de opinião, matizada e não absoluta, foi lida por seus seguidores de acordo com suas próprias ideias, procurando nas palavras do escritor paulistano o reflexo de seus preconceitos em relação à música dos meios eletrônicos de comunicação.

Das mencionadas canções Nêgo Bamba e Desgraça pouca é bobage, Mário de Andrade valorizou a maneira como o compositor José Aymberê dividiu as frases do canto, porque coincide "curiosamente com o processo improvisatório vocal dos «blues» afroainques". Também aplaudiu a interpretação da cantora e atriz Otília Amorim; a riqueza do caráter orquestral, e a "escolha das sonoridades vocais". Do terceiro exemplo, Benedito é ôro só, ele gostou porque:

[...] é uma adaptação admirável dos processos musicais de Maracatus, conseguindo, sem descaracterizar nada, tirar os defeitos da manifestação popular, em principal o excesso desequilibrado da percussão que chega às vezes a impedir totalmente que se escute a linda melodia ${ }^{50}$.

Esse acerto da percussão referido foi obtido por meio da incorporação "discreta" de um instrumento de cordas batidas, e esse "sem descaracterizar nada", dito por ele mesmo, significaría que Mário de Andrade não se incomodou com o arranjo feito pela Victor e achou que aquela mudança na percussão estava em harmonia com o espírito da peça musical original ${ }^{51}$.

47 Nêgo bamba. Samba-batuque interpretado por Otília Amorim, discos Victor №33413, de autoria de José Aymberê de Almeida, gravado em 1930.

48 Desgraça pouca é bobage. Samba interpretado por Otília Amorim, discos Victor N³3404, de autoria de José Aymberê de Almeida, gravado em 1930 (disponível para escuta no Arquivo IEBUSP).

49 São Benedito é ôro só. Jongo interpretado por Mota da Mota, discos Victor N³3380, de autoria de Mota da Mota, gravado em 1930.

50 Andrade. "Carnaval tá aí." [1931] Taxi e Crônicas no Diário Nacional, p. 322.

51 Acerca dos arranjos musicais feitos na época, ver: Teixeira, Mauricio de Carvalho. Música em Conserva. Arranjadores e modernistas na criação de uma sonoridade brasileira. (Dissertação) Universidade de São Paulo, 2001, e Bessa. "Um bocadinho de cada coisa»: trajetória e obra de Pixinguinha. História e música popular no Brasil dos anos 20 e 30. 
Independentemente do gosto musical de Mário de Andrade e das polêmicas que o gramofone e seus discos foram despertando entre seus contemporâneos, notase que o fenômeno fonográfico não passou desapercebido. $\mathrm{O}$ ouvido e o lápis do escritor paulistano prestaram-lhe atenção, e suas observações ficaram dispersas em artigos dedicados a outros assuntos, nas capas de seus discos e nos rascunhos de textos que uma vez pensou em escrever. A constituição de sua coleção de discos e sua curiosidade por tudo que tivesse relação com a atividade musical de seu país fizeram com que ele contribuísse para a diferenciação entre a música popular tradicional e a música popular urbana, diferenciação esta que terminará por criar a polissemia do atual conceito de música popular.

\section{Revolução tecnológica: disco, rádio e cinema}

Desde os primeiros anos do século $\mathrm{XX}$, a invenção da gravação e reprodução do som começou a gerar mudanças que afetariam profundamente a atividade musical do século e, lentamente, afetariam também o conceito de música popular. Grandes indústrias consolidaram-se na Europa e nos Estados Unidos com o objetivo de comercializar essa invenção, apostando nesse nicho de mercado que potencialmente lhes proporcionaria vendas invejáveis. Para garantir o êxito de sua empresa, foram postas em marcha campanhas publicitárias que ocultavam os interesses comerciais de seus donos, enfatizando a criação de imaginários que assegurassem a compra de seus produtos. O mundo empresarial manteve-se escondido do consumidor final, a quem vendia-se simplesmente um produto que prometia um ambiente de maior diversão e variedade. Aos poucos, a indústria discográfica colocou os intérpretes e alguns compositores como produto a ser comprado e, atrás de seus rostos, escondeu toda uma estrutura que tornava possível a produção de um disco, como é o caso dos arranjadores, engenheiros, técnicos, publicitários, vendedores, distribuidores, etc.

É possível perceber, nos escritos de Mário de Andrade de finais dos anos 1920, um certo regozijo com a chegada do cinema sonoro e com a difusão do disco. Ele acreditou, em um primeiro momento, que o cinema era o maior ganho da arte 
moderna e que o disco servia para a conservação da música popular ${ }^{52}$. Foi um clima geral de regozijo do qual também foi exemplo a afirmação do cronista Orestes Barbosa, que reivindicou o trabalho dos músicos próximos à indústria discográfica e afirmou que "O samba tem no rádio um grande servidor" 53 . Esse entusiasmo foi acentuado entre aqueles que participaram da chegada das novas tecnologias mas, paulatinamente, essa alegria foi mudando e surgiram alguns desconcertos..

Na América hispanófona, parece que o clima não foi diferente. No México, um dos países favoritos da empresa discográfica, Rubén M. Campos orgulhava-se, em 1928, de dizer que a canção mexicana "triunfa hoy en las grandes ciudades de los Estados Unidos. No hay teatro de moda ni salón de variedades donde no se dedique un intermedio a la canción mexicana, lo mismo en California que en Nueva York o Lousiana" 54 , e todo esse reconhecimento foi atribuído às gravações vendidas no país vizinho. Também foi motivo de reconhecimento, a participação de um músico local na precoce indústria discográfica. Em 1915, ao fazer a biografia do famoso tenor porto-riquenho Antonio Paoli (1871-1946) e mostrá-lo como uma das principais figuras de projeção internacional, Fernando Callejo Ferrer terminou seu relato dizendo:

Afortunadamente, su posición económica, desahogada, pues los records fonográficos le producen una buena renta, le permite vivir descansadamente sobre los laureles ganados en su carrera triunfal ${ }^{55}$.

O tenor porto-riquenho efetivamente ganhou grande fama como cantor de ópera graças à sua assídua participação nas primeiras gravações. Estima-se que ele gravou cerca de 400 peças em um período de 20 anos, um número superior ao das gravações que foram realizadas por seu colega Enrico Caruso ${ }^{56}$. O trabalho como

52 “...O Malherbe da história moderna das artes é a cinematografia. Realizando as feições imediatas da vida e da natureza com mais perfeição do que as artes plásticas e as da palavra (e note-se que a cinematografia é ainda uma arte infante, não sabemos a que apuro atingirá), realizando a vida como nenhuma arte ainda o conseguira, foi ela a Eureka! das artes puras" (Andrade, Mário de. $A$ escrava que não é Isaura. São Paulo: Livraria Lealdade, 1925, p. 90).

Em relação ao cinema, Mariza Lira foi a única autora consultada que mencionou a música difundida pelos filmes, citando peças como a valsa Mulher Enigma, composta por Plínio da Brita para o filme que levou o mesmo nome; a valsa Sonhos azues, de João de Barros e Alberto Ribeiro, usado no filme "O João Ninguém" (1936), dirigida por Mesquitinha, e a valsa Bonequinha de Seda, do filme de 1936 de mesmo nome, em que atuou a compositora da peça, Gilda de Abreu (Lira. Brasil sonoro. Generos e compositores populares. p. 225).

${ }^{53}$ Barbosa. Samba: sua história, seus poetas, seus músicos e seus cantores. [1933] p. 111.

${ }^{54}$ Campos. El folklore y la música mexicana. p. 78.

${ }^{55}$ Callejo Ferrer. Música y músicos portorriqueños. p. 157.

56 Shawe-Taylor, Desmond. "Recording." Grove Music Online, 2011. 
intérprete de Antonio Paoli pode ser apreciado na interpretação da ária "Mia tu sei", da ópera Carmen, de Georges Bizet, em gravação feita pela Victor em Porto Rico em $1905($ faixa 15) 57.

O entusiasmo inicial de Mário de Andrade com os meios elétricos de difusão diminuiu com o passar dos anos e, embora não tenha chegado à censura, as críticas que em geral fez ao meio artístico atingiram também a música mecânica. Tudo indica que, depois da sua passagem pelo Departamento de Cultura, Mário de Andrade teve momentos de crise pessoal, particularmente durante os anos em que viveu no Rio de Janeiro, e não seria estranho afirmar que seu estado anímico seja em parte responsável pelas críticas enérgicas que lançou naquela época ao mundo artístico.

Não obstante, em 1931, Andrade até tinha ainda um tom mais moderado. No artigo "A música no Brasil" 58 , escreveu que a escolha da discografia citada tinha sido feita com a esperança de que seus leitores ingleses pudessem escutar em algum momento os exemplos musicais mencionados por ele. Nessa ocasião, o musicólogo fez uso do papel de conservação e divulgação pelo qual havia saudado a discografia, tanto em relação à música folclórica e popular, quanto à erudita. Andrade reconhecia que "são inumeráveis os maxixes e sambas valiosos que têm aparecido na imprensa musical e na discografia brasileira para que os possa citar" e que, "dos sambas de criação recente, merecem referência, o admirável Sinhô do Bom-Fim"59, de Juracy Camargo $(\delta \text { faixa } 16)^{60}$, entre outros exemplos ${ }^{61}$.

Curiosamente, nem sempre os cronistas e defensores da música popular urbana simpatizaram com o que acontecia em torno dos meios de comunicação eletrônicos. Francisco Guimarães (Vagalume), apesar de escrever um texto reivindicando o valor do samba, disse que este morria quando chegava à indústria discográfica "Onde morre o samba? [...] quando ele passa da boca da gente de roda,

${ }^{57}$ Mia tu sei (ópera Carmen). Aria interpretada por Antonio Paoli, discos Victor N²92035, de autoria de Georges Bizet, gravado em 1905 em Porto Rico.

${ }^{58}$ Andrade. "A música no Brasil." [1931] Música, doce música. Estudos da crítica e folclore

${ }^{59}$ Ibid., p. 20.

60 Sinhô do Bonfim. Maxixe interpretado por Elpidio L. Dias (Bilu) com Orquestra Victor, discos Victor No33211, de autoria de Juracy Camargo, gravado em 1929.

${ }^{61}$ Sobre o batuque Babaô-Miloque, também elogiado pelo autor, ver: Gonçalves. Música em 78 rotações: «Discos a todos os preços» na São Paulo dos anos 30. pp. 54-ss. 
para o disco da vitrola. Quando ele passa a ser artigo industrial..."62. De fato, seu livro é uma denúncia da frequência com que os músicos das casas de discos roubavam a autoria de sambas que eram compostos pela classe baixa que morava nos morros do Rio de Janeiro, verdadeiros criadores anônimos do gênero, segundo ele.

No México, Rubén M. Campos, apesar de se ter mostrado orgulhoso da difusão da música de seu país, também acreditou que o fonógrafo era um inimigo da música popular ou folclórica, reproduzindo o temor da visão de mundo romântica da época.

Las formas primitivas han ido evolucionando y perdiéndose, desde la venida del fonógrafo, y hay que apresurarnos a recoger las pocas que quedan vivas, y que mañana serán un recuerdo etnográfico, consignado en un libro, como son ahora los cantos de hace un siglo ${ }^{63}$.

Miguel Galindo, seu conterrâneo, também se mostrou receoso quanto à popularidade do fonógrafo:

Por otra parte, la importación extranjera es no sólo de maquinaria y artefactos útiles a las necesidades de la vida ordinaria, sino que llega al dominio del arte estético, y se está llenando la nación de fonógrafos, victrolas y «discos», pianolas, autopianos $\mathrm{y}\langle\operatorname{rollos}\rangle^{64}$.

Esses dois autores, assim como todos os que estiveram embebidos na visão romântica do nacionalismo musical, não viram com bons olhos os caminhos abertos pela fonografia. Em 1930, fundou-se a Associação Brasileira de Música, que buscava, entre outras coisas, "lutar contra a «evidente decadência pala inércia das nossas melhores forças musicais e invasão da arte fácil e vulgar»”. De acordo com Arnaldo Contier, em finais dos anos 1920, esse grupo de músicos percebeu que “o fantasma da música romântica" já não era um impedimento para o desenvolvimento de seu projeto nacionalista, mas sim a música popular, que se expandia por todo o país com as emissoras de rádio e o mercado do disco ${ }^{65}$.

De acordo com Michael Löwy e Robert Sayre, para o romantismo, um dos problemas trazidos pela modernidade foi a mecanização do mundo já que, conforme a sua visão, era problemático o protagonismo da máquina na vida diária, ponto de

\footnotetext{
${ }^{62}$ Guimarães, Francisco (Vagalume). Na roda do samba. [1933] Rio de Janeiro: Funarte, 1978, pp. 30-31.

${ }^{63}$ Campos. El folklore y la música mexicana. p. 101.

${ }^{64}$ Galindo. Nociones de la historia de la música mejicana. p. 32.

${ }^{65}$ Contier. Brasil Novo. Música, nação e modernidade: os anos 20 e 30. pp. 220-221.
} 
vista este que já fora marcado com a revolução industrial ${ }^{66}$. No pensamento musical, essa recriminação é observável na prevenção que alguns contemporâneos mostraram em relação ao rápido avanço dos modernos meios de gravação. Essa "mecanização da música" levou a mudanças notórias na atividade musical e foi culpada, por exemplo, da menor demanda de músicos intérpretes em espaços tradicionais de música em vivo, como dança e festas, que foram substituídos pelas gravações discográficas. Não foi à toa que, no início da indústria discográfica, cunhou-se a expressão "música mecânica" para denominar a música que circulava nos discos. Além disso, enquanto o romantismo procurava manter as tradições, a mentalidade de venda da indústria discográfica procurava mudanças tecnológicas e a renovação de repertórios.

Também para Mário de Andrade, os modernos meios de reprodução do som estavam causando transformações sociais e musicais que, timidamente, enunciou em alguns de seus escritos.

Por exemplo, em 1930, ele sugeriu, com um pouco de picardia, que o fonógrafo parecia ser mais um instrumento musical que um meio de reprodução:

...o fonógrafo, possuindo técnica própria e que, no caso, é mecânica, e possuindo timbre especial que lhe pertence particularmente, é um instrumento como qualquer outro, possível portanto de adquirir especialização. Música pra fonógrafo, como existem músicas pra pianola ${ }^{67}$.

A esta observação, Mário de Andrade acrescentou que, em sendo o fonógrafo um instrumento musical, era preciso descobrir qual era o melhor uso para ele, assim como se reconhecia que o piano devia ser usado em salas fechadas e a flauta dava bom resultado ao ar livre. Seguindo sua própria argumentação, afirmou que o melhor uso do aparelho era o lar e não as salas de cinema, onde estava substituindo as orquestras ao vivo, mas em que a única coisa que conseguia era repetir a música que os assistentes tinham acabado de ouvir em casa.

Esta não foi uma preocupação somente de Mário de Andrade, pois os próprios músicos sentiam que suas condições trabalhistas estavam mudando. Segundo José Geraldo Vinci do Moraes, essas novas condições levariam à profissionalização do músico popular, agora solicitado pelas empresas radiofônicas e

\footnotetext{
${ }^{66}$ Löwy e Sayre. Revolta e melancolia. O romantismo na contramão da modernidade.

${ }^{67}$ Andrade, Mário de. "História da música." Diário Nacional, 15 jan. 1930.
} 
fonográficas, com uma dedicação de tempo maior ${ }^{68}$. Miguel Galindo, no México, também se preocupou com a perda do trabalho habitual dos músicos diante do uso cada vez mais frequente dos gramofones: "la importación de música extranjera y la máquina musical reducen aun más la producción, porque el artista necesita del estímulo material, de la compensación a su trabajo para vivir"69.

Mário de Andrade publicou no Diário Nacional, em 1931, um pequeno artigo em que resenhou alguma música gravada. Nesse artigo, observou rapidamente que a música de carnaval era antes difundida por meio da imprensa musical e das orquestras nos bares, que, depois, foram substituídos pelos discos. Mais tarde, no final de sua vida, Mário de Andrade notava que "o disco, o rádio, o cinema e demais instrumentos mecânicos", tinham modificado a difusão da música erudita, tonando-a acessível a todos os públicos. No prefácio ao livro Shostakovich, explicou que algumas formas musicais de câmara, a sinfonia e a sonata, que eram próprias da música erudita dos séculos XVIII e XIX, deixavam de ser exclusivas das classes sociais altas e estavam próximas ao povo graças à difusão em massa que a música erudita começava a ter nos meios de comunicação ${ }^{70}$.

Em concordância com a preocupação que sentiu em relação ao papel social do artista - preocupação que se acentuou no final de sua vida -, o escritor paulistano igualou o rádio e a vitrola aos teatros e ao cravo do passado, por meio dos quais os músicos difundiam sua música e seu talento, tal como acontecia no presente com os novos meios. O perigo que Andrade via nesse tipo de mediação, incidia no risco de se perder na "virtuosidade gratuita", esquecendo-se a função humana que a arte devia ter ${ }^{71}$. Com preocupações diferentes, mas também sob um enfoque histórico, Rubén M. Campos comparou o fonógrafo com os antigos meios de difusão musical, "los organillos, los vendedores de ante y las cantadoras de las ferias, eran los medios de propaganda musical sustituidos hoy por los fonógrafos"72. Desse

\footnotetext{
${ }^{68}$ Moraes, José Geraldo Vinci de. Metrópole em sinfonia. História, cultura e música popular na São Paulo dos anos 30. São Paulo: Estação Libertade, 2000, pp. 102-111.

${ }^{69}$ Galindo. Nociones de la historia de la música mejicana. p. 33.

70 Andrade. "Shostacovich." [1945] Música Final. Mário de Andrade e sua coluna jornalística Mundo musical, p. 399.

71 Andrade. "A carta de Alba." [1943] Música final. Mário de Andrade e sua coluna jornalística Mundo musical, pp. 60-64.

${ }^{72}$ Campos. El folklore y la música mexicana. p. 82.
} 
modo, parece que o fonógrafo foi considerado um ingrediente novo de uma prática antiga: a difusão musical.

Mariza Lira também notou que a música popular, particularmente, tinha novos meios de difusão e, em 1938, responsabilizou a rádio por esse papel: "O rádio deu ensejo a que se tornassem conhecidas em todo o Brasil as harmonias típicas brasileiras"73. E, junto com essas melodias, também seus músicos fizeram-se amplamente reconhecidos: "Conhecidíssimo nos meios radiofônicos e também nas emprêsas gravadoras de discos, Pixinguinha é com sua flauta mágica, um dos animadores máximos da nossa música popular"74.

Assim como a fonografia, a rádio esteve na mira de alguns escritores, despertando amores e desamores quase que por igual, conforme o papel que cada um lhe outorgou. Para Mário de Andrade, na década de 1940 já era evidente que a rádio e o cinema impediam que houvesse "calmas províncias longíquas" onde se tradicionalizara a música. Faziam-se tradicionais, não peças específicas, mas sim somente os elementos constitutivos da melodia, do ritmo, fórmulas cadenciais e fragmentos melódicos $\operatorname{curtos}^{75}$. Na realidade, o tema que interessava a Mário de Andrade naquele momento era o dos processos de folclorização e popularização da música, dentro do qual ele concluiu que o rádio cumpria uma função.

Na América de hispanófona, por exemplo, Emirto de Lima sentiu simpatia por determinadas situações que a rádio colombiana propiciou, como é o caso da participação da música popular folclórica nos microfones de suas cabines. Em um curto subcapítulo, intitulado "Grupos folklóricos ante el microfone", o autor contou que, em Barranquilha:

[...] se han fundado últimamente entre nosotros numerosas agrupaciones artísticas que actúan en diversas estaciones de la República y presentan programas de música completamente colombiana, a veces bien seleccionadas estas estaciones, y otras mostrando estas transmisiones cierta falta de cohesión y ensayo ${ }^{76}$.

\footnotetext{
${ }^{73}$ Lira. Brasil sonoro. Generos e compositores populares. p. 99.

74 Ibid., p. 272.

75 Andrade. "A modinha e Lalo." [1941] Música, doce música. Estudos da crítica e folclore, p.

${ }^{76}$ Lima. Folklore colombiano. p. 187.
} 341. 
Além da evidente matiz nacionalista dessa sua avaliação da rádio, Emirto de Lima ilustrou o perfil do músico que tinha acesso a esses espaços nas cidades da seguinte maneira:

Algunos de estos grupos de músicos y artistas nacionales son obreros que durante todo el día desempeñan sus menesteres en fábricas y talleres. Y llegada la noche, tras ardua labor realizada durante largas faenas, no tienen inconveniente en tomar en sus manos la guitarra, la bandurria y el tiple para dirigirse a una estación radiofónica a ejecutar pasillos, danzas y bambucos o para cantar canciones típicas y nacionales ${ }^{77}$.

A simpatia com que Emirto de Lima observou a radiodifusão do país esteve relacionada com o fato de que ele mesmo trabalhou na emissora A Voz de Barranquilha como regente, compositor e pianista. Em sua opinião, a radiodifusão era benéfica e,

Se necesita estar completamente desprovisto de sensibilidad y no tener un átomo de interés en las cosas del presente y en el porvenir de la cultura patria, para no mirar con profunda simpatía el florecimiento de la radiodifusión en estos dos últimos lustros $^{78}$.

Um dos pesquisadores "desprovidos de sensibilidade" — nas palavras de Lima - foi Francisco Curt Lange que, em 1936, mostrava-se muito receoso com as incursões da rádio comercial na América Latina:

[...] en la difusión radio eléctrica comercializada no existe principio estético alguno y como la estética es un factor capital en la educación y divulgación cultural, ninguna persona que se ocupa de los problemas culturales de un país o se preocupa por ellos, puede simpatizar con este nuevo medio impuesto al ambiente ${ }^{79}$.

Para o alemão radicado no Uruguai, na rádio, a música era tratada com menosprezo e sem a atenção de que necessitava. Pela sua perspectiva, a verdadeira tarefa da rádio era educar e, portanto, o conteúdo de seus programas devia ser dirigido pelos governos de cada país.

Pero al ampliar el horario, se presenta el problema de «rellenar» el espacio que mide entre las ocho de la mañana y las doce de la noche, para citar un ejemplo. [...]. Se recurrió para ello a la música y como el disco elimina el problema acústico, no necesitándose de micrófonos, se le emplea por su comodidad, su costo reducido frente al ejecutante vivo, la fidelidad de la reproducción y la pasmosa variedad que ofrecen los catálogos de las casas impresoras. Pero como la organización de una Discoteca exige la inversión de grandes sumas, se conforma con un pequeño «surtido» - hablemos siempre en términos comerciales - que está

77 Ibid.

${ }^{78}$ Ibid., p. 177.

79 Lange. "La difusión radio eléctrica como medio de educación de las masas y factor de difusión cultural e científica." p. 137. 
sometido a una dura prueba de resistencia, ya que cuesta «rellenar», con música, tantas horas diarias de transmisión ${ }^{80}$.

Por outro lado, além das mudanças nos mecanismos de difusão da música e suas consequências, Mário de Andrade também percebeu que a indústria discográfica tinha desencadeado certas mudanças musicais. Elas não só se davam na música popular, mas também na prática da música erudita, a qual tendia para a fixação de parâmetros interpretativos. Em um artigo a respeito da vida musical de Ernesto Nazareth, ele afirmou que o aspecto mais volátil da música era a interpretação, assinalando o fato de que a música gravada estava impondo certos modos:

...o fonógrafo talvez venha a se constituir num elemento prejudicial de decadência e academismo. Porque, conservando as interpretações que os compositores de hoje nos dão das suas próprias obras, estes recordes fonográficos, sob o pretexto reacionário da tradição, serão futuramente verdadeiros tabus, impedindo a liberdade interpretativa ${ }^{81}$.

Quanto à música popular, Mário de Andrade inquietou-se ao observar a popularização de uma figura rítmica na música brasileira que era muito usada na música radiofônica. Nosso autor suspeitou que o costume de substituir duas colcheias de um tempo por uma síncopa permitia ao cantor pronunciar três sílabas em vez de duas, e que esta fórmula tinha sido adotada da música que se ouvia na rádio, em que era frequente. Deixou aberta a pergunta sobre até que ponto a radiodifusão estava influenciado na tradicionalização de elementos musicais, como era o caso dessa "sincompação do rádio carioca" 82 .

Em resumo, Mário de Andrade estava convencido de que a música de rádios e discos servia quase como "meio de transporte" para levar certos gêneros a lugares novos: a música erudita, que saía das salas de concerto para a rua; a música popular tradicional, que entrava no gabinete do pesquisador; os discos, que podiam ilustrar textos acadêmicos e viajar pelo mundo; as discotecas, que podiam reunir e disponibilizar todo tipo de música a todos os públicos, etc. Por outro lado, o musicólogo também percebeu que esse mesmo poder de conservação e difusão dos discos estava gerando algumas mudanças na própria música, como a fixação de

\footnotetext{
${ }^{80}$ Ibid., p. 138.

${ }^{81}$ Andrade. "Ernesto Nazareth." [1940] Música, doce música. Estudos da crítica e folclore, p.

82 Andrade. "Música brasileira." [1942] Música, doce música. Estudos da crítica e folclore, p.
} 
modos de interpretar a música erudita e a popularização de elementos nitidamente musicais, usados habitualmente na música popular gravada.

\section{Fronteiras difusas}

Em 1907, os irmãos Raymond e Harry Sooy, engenheiros da Victor Talking Machine Company, realizaram sua primeira viagem para fora dos Estados Unidos. Um dos primeiros países visitados foi o México, sob a encomenda de levar de volta gravações de música local. Dez dias antes de sua partida, os engenheiros enviaram suas grandes malas à Cidade do México e, sem saber espanhol, partiram para seu destino. Ao que tudo indica, chegaram à cidade portuária de Veracruz, estiveram dois dias na Cuernavaca e o tempo restante na capital do México, onde foram ajudados por um manager americano e por assistentes falantes de espanhol. Depois, retornaram à Filadélfia com 207 gravações de música mexicana, recolhida em menos de um mês, conforme contou Raymond em seu diário pessoal ${ }^{83}$.

Muito provavelmente, durante essa viagem, os irmãos Sooy gravaram a matriz do disco Victor número 62037-B, em que se reproduz uma cena citadina entre um transeunte de classe popular e um vendedor de gramofones. O diálogo teve início na porta de uma loja, entre o vendedor que oferecia audições musicais em um gramofone Victor e um cliente que pediu para ouvir uma canção inocentemente, sem desconfiar da propriedade inanimada, do reprodutor musical nem da lógica de mercado que estava por detrás do oferecimento do vendedor ( $\delta$ faixa 17$)$.

- Pesen señores, señoritas y niñas, pasen a oír sus deliciosas canciones en el gramófono, Victor. Pasen señores. Es el aparato más perfecto que hasta el siglo XX se ha conocido. Pasen señores, pasen!

- Oiga usted señor

- Qué cosa deseaba usted, caballero?

- Hágase el favor de poner usted una canción de esas muy requiriosas

- Cómo de qué la quería usted?

- Pois d'esas que cantan los señores Ábrego y Picazo

- Pos le voy a poner a usted una. Óigala usted.

[Música]

83 Sooy, Harry O. "Memoir of my Career at Victor Talking Machine Company (1898-1925)." Nicholas Pensiero Collection at the Hagley Library, Disponível em <http://www.davidsarnoff.org/ sooyh.html>, (8 dez. 2011) e Sooy, Raymond "Memoirs of my Recording and Traveling Experiences for the Victor Talking Machine Company." David Sarnoff Library, Disponível em <http:// www.davidsarnoff.org/soo-maintext.html>, (8 dez. 2011). 
- Cual es señor?

- El zenzontle

- Ah, bueno, bueno!

[Música] Cuando el zenzontle llegué / sus sueños arrullar / déjalo vida mía ...

- Eso de "vida mía" lo dice usted por mi mujer, valedor?

- No señor, así dice el aparato.

- Ah!!! así dice? No, pues a mi usted no me vea cara de pato. Mejor hágame el favor de ponerme otra de amor y contra ella

- Ahí le va La china Hilaria

[Música] La vi volar /

- ...y la golondrina, vale?

[Música] Al árbol del olvido / para saber

- Mire, a mi... a mi no me hace saber usted nada absolutamente. Mejor póngame usted una sentimental, no le parece?

- El jarabe tapatio está pedido por esa señorita.

- [Música] Si usted me quiere de formalidad / si usted me quiere de formalidad / primero me ha de enseñar / el modo de enamorar / que cuando tenga dinero / nos iremos a pasear

- Y bueno, adonde se la quiere usted llevar a pasear, amigo.

- A Santanita, conmigo!

- No, no, no. Yo no quiero eso. A mi no me pone ya más fiestas, amigo

- Pois entoi hágame el favor de pagar

- Cuanto le debo?

- Diez centavos por cabeza

- Como por cabeza?!

- Sí, señor

- No. Pues yo no le pago a usted.

- Le quito el sombrero!

- Que no me quita nada!

- La cobija entonces

- No señor, eso si que no

- El ...

[Confusão]

[Apito]

- A ver, párese usted aquí. A ver usted

- Yo señor? si yo no le hago nada ni le debo tampoco!

- Ni yo tampoco, pero conste amigo que no me voy y no me lleva ni...

- A ver todos: a la comisaría! ${ }^{84}$

Esse diálogo foi classificado pelos engenheiros da Victor como um "male vocal duet with guitar" e recebeu o título de Pleito en el gramofone. Os intérpretes foram o tenor Jesús Ábrego e o barítono Leopoldo Picazo, que formaram o dueto Ábrego e Picazo - citado no diálogo - e tinham gravado outras canções para a

${ }^{84}$ Pleito en un gramofono. Duo masculino com violão interpretado por Ábrego e Picazo, discos Victor N62037, de autoria de Ábrego y Picazo, gravado em 1907 em México. 
Victor, como as mencionadas no diálogo ${ }^{85}$. Além do evidente papel promocional desta peça, chamou a atenção que a situação dava-se entre um homem pobre e talvez camponês, por seu sotaque ao falar, e o mundo moderno da cidade, onde gramofone e dinheiro iam juntos. É um exemplo precoce do mundo semi-rural — ou semiurbano - a que chegaram os modernos reprodutores de som naquele continente.

Parece que esse tipo de produção teve acolhida por parte do público, pois existe outro exemplo em que são reproduzidos elementos similares, só que no contexto brasileiro e 22 anos depois. Trata-se de um dos primeiros discos feitos em terra brasileira por outra das grandes empresas discográficas da época, a Columbia Phonograph Co., que tinha iniciado sua fábrica de discos no Brasil naquele momento. O disco $\mathrm{N}^{\mathrm{o}} 5030$ trazia em um de seus lados a "prosa sertaneja" $\hat{O} d e$ casa!, gravada por Batista Jr. em São Paulo e lançado no mercado em 1929. Assim como o exemplo mexicano, aqui os protagonistas voltaram a ser o gramofone e sua música, mas como intermediários entre o mundo rural e o urbano, apresentado também em forma de diálogo jocoso e com interlúdios musicais. As autorreferências também estiveram presentes. No exemplo mexicano, era um disco marca Victor que reproduzia a voz do vendedor oferecendo gramofones Victor, além das menções dos personagens a eles mesmos e a suas outras gravações. No exemplo brasileiro, a autorreferência aparece quando, no diálogo, especifica-se que o gramofone em questão era marca Columbia (“colúmbica”), empresa também produtora do disco $(\delta$ faixa 18).

- Ô, de casa! Bom dia, cumadre!

- Bom dia, cumpadre. Entre!

- A cachorrada num morde?

- Num morde não. Isso é só garganta essa pestaiada

- Então com licença. Bom dia cumadre. Então como vamo tudo por aqui?

-Nóis vai bem. Sente. Então, como foi de passeio de capitar?

- Bem bom também. Mais ô cumadre, que terra de trapaiação. Que rebuliço de mundice, de genaiada misturada com máscara, cumadre, nossa! Mas a chuva escagiô, coitado do carnavá, tão beleza de buniteza eu sinti...

- Que pena, não, cumpadre? Ué, que caixica bonitica é essa?

- Não é caixica. Essa é uma grafonólica linha culúmbica

- Hum, dessas que canta, é?

${ }^{85}$ El jarabe tapatio e El zenzontle, gravados em 1905, e La China Hilaria, gravada em 1907, durante outra viajem da Victor por terras mexicanas e interpretadas pelo mesmo dueto. Encyclopedic Discography of Victor Recordings. Regents of the University of California, Disponível em http:// victor.library.ucsb.edu (20 oct. 2011). 
- É isso mesmo. É encomenda de meu Maneco e eu derrubei no caminho e quebrô quase tudas chapas. Só ficô uma.

- Ô, que pena. Toca pra nóis iscuitá essa uma intão.

- Tem razão, cumadre. Vamo porvá outra veiz. Deixa dá corda primero, que vê? Agora

[Bajo cantando en italiano]

- Que voiz, cumpadre, parece bisoro!

- Num, é, cumadre? Eu também pensei. O moço que vendeu disse que é voiz de baixo.

- Hum, é voiz de baixo, é? Intão, vira a chapa

- É, do outro lado tem uma muié que canta, com voiz, assim, de soprano. Qué ve? Ó.

[Soprano cantando]

- Pára, pára. Porque parec'sê gato isprimido, noss'inhora! Quar, cumadre, moda bunita são as nossa. A gente pega a viola numa noite de luá e começa assim.

[Música]

Marica Chiquinha bamo

pelo centro de sertão que a barra do seu vestido

chega, não, chega no chão

e as tranças do seu cabelo

martrata meu coração

- Bom, cumadre, vô indo, a prosa tá boa mais vô indo

- É cedo, cumpadre, espera o café

- Não, té minha, si deus quisé

- Dá lembrança pra cumadre

- Bem lembrado ${ }^{86}$

Observa-se que, nos dois exemplos, o gramofone mostrou-se próximo à classe popular. No exemplo brasileiro, esse grupo foi mais bem caracterizado como camponês, pois o sotaque caipira foi usado claramente e se recriou uma paisagem sonora rural com efeitos de som, como o latido de cachorro que abre e fecha a cena. Como assinalou Camila Gonçalves Koshiba, nesse exemplo, o gramofone não se apresentou como uma novidade no mundo camponês, pois a comadre sabia do que se tratava aquele aparelho ${ }^{87}$. Através de documentos como esse, é possível pensar que a "grafonólica" - elemento da cultura urbana moderna - estava entrando no mundo rural brasileiro já em 1929. Por outro lado, a gravação mexicana, feita no começo da indústria discográfica, apresenta uma caricatura sonora do que possivelmente era o mundo urbano latino-americano do começo do século XX: cidades em processo de modernização, com gramofones nas ruas, por onde transitavam pessoas provenientes do campo e não familiarizadas, mas curiosas com as últimas novidades e, portanto, consumidoras potenciais dos novos produtos.

86 Ô de casa!, interpretado por Batista Jr., discos Columbia Nº5030, gravado em 1929 (São Paulo). Transcrição Camila Koshiba Gonçalves. p. 142.

${ }^{87}$ Gonçalves. Música em 78 rotações: «Discos a todos os preços» na São Paulo dos anos 30. 
Um dos escritos mais evidentes para identificar as transformações sofridas pelo conceito de música popular no compasso dessas fronteiras difusas é o artigo "A música e a canção populares no Brasil. Ensaio crítico-bibliográfico” (1936) ${ }^{88}$, de Mário de Andrade, publicado quando ele trabalhava como diretor do Departamento de Cultura de São Paulo. Essa reflexão a respeito da dicotomia campo/cidade partiu de sua crítica a uma definição de canção popular, que tinha sido retomada por Julien Tiersot da Encyclopedia de la Musique, de Lavignan. Para estes dois autores, a legítima canção popular devia ser tanto antiga quanto nativa ${ }^{89}$. De sua parte, Mário de Andrade, considerava que fatores como a formação recente da nação brasileira e sua essência mestiça poderiam parecer impedimentos para que existissem canções populares no Brasil, mas ele acrescenta que, muito pelo contrário:

Tanto no campo como na cidade florescem com enorme abundância canções e danças que apresentam todos os caracteres que a ciência exige para determinar a validade folclórica duma manifestação ${ }^{90}$.

Andrade argumentava que, na América, era impossível adotar o critério do folclore segundo o qual as manifestações urbanas não eram populares, e expressou com argumentos escritos o que os exemplos sonoros citados recriavam:

Nas regiões mais ricas do Brasil, qualquer cidadinha de fundo do sertão já possui água encanada, esgotos, luz elétrica e rádio. Mas por outro lado, nas maiores cidades do país, no Rio de Janeiro, no Recife, em Belém, apesar de todo o progresso, internacionalismo e cultura encontram-se núcleos legítimos de música popular em que a influência do urbanismo não penetra ${ }^{91}$.

Provavelmente, os termos com que Mário de Andrade escreveu esse artigo eram polêmicos para o pensamento do folclore. Assim, para evitar interpretações erradas, ele acrescentou, enfaticamente, que era necessário incluir o popular urbano nos estudos da música popular.

Tentando matizar a complexidade da realidade musical brasileira, nosso autor abriu um leque na terminologia. Expôs a existência de um folclore urbano

88 Andrade. "A música e a canção populares no Brasil. Ensaio crítico-bibliográfico." [1936] Ensaio sobre a música brasileira.

89 Julien Tiersot foi um autor conhecido e respeitado entre os intelectuais da época pois, além de ter sido chamado, entre outros autores, por Guillerme Pereira de Mello para explicar a importância da canção popular, na biblioteca de Mário de Andrade estão conservadas 11 de suas obras, publicadas entre 1889 e 1932 (Mello. A música no Brasil desde os tempos coloniais até o primeiro decênio da república. p. 37).

90 Andrade. "A música e a canção populares no Brasil. Ensaio crítico-bibliográfico." [1936] Ensaio sobre a música brasileira, p. 165.

${ }^{91}$ Ibid., p. 166. 
dentro do qual havia dois tipos diferentes: um que era "virtualmente autóctone", nacional e "essencialmente popular", e outro que era "feito à feição do popular", ou influenciado pelas modas internacionais. Andrade concluiu seu escrito dizendo:

Recusar a música popular nacional, só por não possuir ela documentos fixos, como recusar a documentação urbana só por ser urbana, é desconhecer a realidade brasileira $^{92}$.

Outro exemplo do tênue limite que Mário de Andrade via entre o campo e a cidade está no artigo "O samba rural paulista" (1937), em que ele põe em prática os métodos etnográficos, certamente aperfeiçoados pelo seu recente contato com o casal Lévi-Strauss. Embora o artigo tenha sido escrito e publicado em 1937, Mário de Andrade esclareceu que se baseou em notas antigas, tomadas por ele em 1931, 1932 e 1934 de forma quase improvisada, e em algumas mais, tomadas em 1937, quando ele afirma que parou "propositalmente em Pirapora, na noite de 4 de agosto, com a intenção determinada de assistir aos sambas"93. Nos anos anteriores, estava "vagando" pela Avenida Rangel Pestana e a rua Manuel Paiva, com sua caderneta de notas, quando ouviu que "roncava um samba grosso [que] nada tinha a ver com os sambas cariocas do Carnaval [...]" e, por se considerar um simples "amador do folclor", seus apontamentos não foram tão completos como gostaria. O artigo procurou descrever com a maior exatidão possível o que Mário de Andrade tinha presenciado, discorrendo sobre os processos de criação coletivos por intermédio de sua experiência de observação.

A dissonância criada entre o adjetivo rural, do título do artigo, e o meio visivelmente urbano da música que analisou, foram uma amostra a mais do seu convencimento - expresso no ano anterior - de que havia fenômenos musicais da cidade que eram provenientes de campo, e que deveriam ser estudados

É interessante observar que Mário de Andrade tomou amostras de samba na Avenida Rangel Pestana, no bairro operário do Brás, onde, casualmente, estavam localizados os estúdios de gravação de pequenas casas de discos paulistas, como a Arte-fone. De acordo com Camila Gonçalves Koshiba, a produção desses selos caracterizou-se por gravar e vender o ambiente musical que se respirava em seu

\footnotetext{
92 Ibid.

93 Andrade. "O samba rural paulista." [1937] Aspectos da música brasileira, p. 37.
} 
bairro, caracterizado por "hábitos peculiares"94 e, talvez, com aroma semi-rural. Sendo assim, não teria sido por acaso que ali fosse o lugar em que Mário de Andrade encontrou uma música que o fizesse parar em seu caminho e tirar sua caderneta, anotando apontamentos para, depois, analisar suas notas e ratificar a necessidade de se estudar a música da cidade.

Mário de Andrade certamente sentiu alguma simpatia pelos discos produzidos no Brás pois, em sua coleção, encontram-se exemplares gravados pela Arte-fone e, na capa de um deles, Andrade escreveu: "Bananeira pode ser tomado como exemplar cientificamente folclorico do samba rural paulista"95. Trata-se do batuque intitulado Bananeira, interpretado por Torres e seu bando de Baitacas, e gravado como o disco $\mathrm{N}^{\mathrm{0}}$ 4023. Não se conhece o ano de gravação, mas é possível que seja posterior a 1937 ou, ao menos, que tenha sido depois desse ano que chegou às mãos do escritor pois, se o tivesse ouvido antes, teria podido mencioná-lo em " $\mathrm{O}$ samba rural paulista" (1937), já que o considerou um exemplo "científico" do gênero 96 .

Embora seja certo que as cidades latino-americanas, em processo de crescimento e modernização, tenham atraído imigrantes do campo, e que eles foram um afluente de cultura rural nas metrópoles, também é certo que, na vida moderna, houve certa reapropriação da cultura camponesa. É provável que, no início, essa retomada da cultura campesina tenha sido impulsionada pela nostalgia romântica, e que, depois, tenha sido fomentada pela indústria do entretenimento, que a maquiou um pouco e vendeu aos habitantes da cidade.

O fenômeno da imitação falseada de tradições camponesas deu-se durante o mesmo período em vários lugares da América Latina, como a Colômbia, onde, em fins do século XIX e início do XX, músicos urbanos representantes da cultura popular, como Antonio M. (El Jetón) Ferro, Alejandro Wills e Albero Varrer,

94 Gonçalves. Música em 78 rotações: «Discos a todos os preços» na São Paulo dos anos 30. pp. 103-110.

${ }^{95}$ Arquivo do Instituto de Estudos Brasileiros. Catálogo Discos Mário de Andrade.

96 A mesma música foi gravada por discos Victor em 1939 (N³3035). Santos, Alcino, de Azevedo, Miguel Ângel et al. Discografia brasileira 78 rpm 1902-1964. Rio de Janeiro: Funarte, 1982. 
fantasiavam-se de camponeses para suas atuações ${ }^{97}$. Além disso, houve países onde a tríade nacionalismo, identidade e romantismo ajudou a alimentar esse imaginário: no México, por exemplo, triunfou a figura do charro, uma representação urbana do fazendeiro camponês, como signo de "mexicanidade".

No Brasil, a representação da cultura caipira ficou exemplificada com sucessos como as narrações de Cornélio Pires, gravadas pela discos Columbia, os duetos Mandi e Sorocabinha, Raúl Torres e Serrinha ou os Oito Batutas, cuja música e performance "não era senão uma releitura urbana do folclore rural" 98 , entre outros agrupamentos. Por outro lado, gêneros como o choro e o samba eram músicas urbanas que se procurava legitimar em suas raízes rurais e, como ilustrou Virgínia de Almeida Bessa: "é que, mesmo preservando o fundo folclórico do qual certamente são tributários, esses temas foram filtrados pela escuta dos músicos populares" ${ }^{\prime 99}$. Além dos discursos de ratificação do popular folclórico, existia, nos centros culturais brasileiros, um evidente e frutífero intercâmbio entre os músicos urbanos e rurais, o que facilmente permitiu que tanto a música das cidades quanto a do campo vivessem constantes influências, até mesmo antes da difusão massiva da rádio e do fonógrafo ${ }^{100}$.

Parece ter sido claro para alguns escritores que esse trânsito da música entre âmbitos rurais e urbanos ocasionava mudanças; não obstante, nenhum viu nesse fenômeno um objeto de estudo interessante. Entre os autores consultados, somente Mariza Lira referiu-se a essa situação sem qualificá-la como uma "deformação" do repertório folclórico em mãos da indústria discográfica, como o faziam os folcloristas tradicionais. Segundo a autora, "Os compositores da cidade tiram das lindas toadas sertanejas motivos para estilizações", e o mesmo teria se dado com outros gêneros. João da Baiana e Getúlio Marinho, por exemplo, “estilizaram um ponto de macumba" e o chamaram No fundo do mar ${ }^{101}$. Segundo a autora, essas

97 Bermúdez. "Cien años de grabaciones comerciales de música colombiana. Los discos de «Pelón y Marín» (1908) y su contexto." p. 132.

98 Bessa. «Um bocadinho de cada coisa»: trajetória e obra de Pixinguinha. História e música popular no Brasil dos anos 20 e 30. p. 99.

${ }^{99}$ Ibid., p. 82.

${ }^{100}$ Ibid., p. 96.

${ }^{101}$ Lira. Brasil sonoro. Generos e compositores populares. p. 99.

Gravada por discos Victor em 1937 ( $\mathrm{N}^{\mathrm{0}}$ 34158), segundo: Santos, de Azevedo et al. Discografia brasileira 78 rpm 1902-1964. 
estilizações foram bem aceitas, pois "No Rio, há muitos arranjos sôbre temas sertanejos em feitio de emboladas, menos pintorescos que originais, mas sempre apreciados"102. Lira voltou ao mesmo assunto ao se referir ao samba: “As Escolas de Samba têm fornecido lindas músicas, é certo, mas concorreram para que o samba perdesse um pouco de seu ritmo primitivo pelas estilizações que se vem fazendo"103.

Mariza Lira também citou, em um de seus livros, a escritora Julia Lopes de Almeida (1962-1934), que observou, a respeito de Catulo da Paixão Cearense, que "Ele não é um violeiro dêsses do sertão, cantador de trovas ingênuas: tem o seu estilo" 104 , dando a entender que também para essa autora existiam diferenças entre a música camponesa e suas representações citadinas. De fato, a difusão desse tipo de repertório não foi insignificante, e cronistas como Orestes Barbosa também o mencionaram: "música regional, agora gloriosa nos discos, nos rádios, nos salões e nos casebres" $" 105$.

O mais interessante desses limites difusos entre as tradições musicais urbanas e rurais é observar que os meios eletrônicos modernos de comunicação foram ferramentas que influíram na divulgação da música das cidades a âmbitos longínquos, ao mesmo tempo em que alimentavam tradições rurais. É sabido que as companhias discográficas, desde cedo, promoveram seus aparelhos e discos por todo o continente sem deixar de visitar as cidades menores e que até mesmo fabricaram gramofones de menor tamanho,visando as "festas no campo", entre outros usos ${ }^{106}$. De acordo com Virgínia Bessa, em 1929, era clara a intenção das empresas discográficas de levar os discos prensados em São Paulo e no Rio de Janeiro para cidades menores ${ }^{107}$.

A difusão da música mecânica não teve limites. Carlos Vega encontrou em suas viagens pelas zonas rurais chilenas, no início dos anos 1940, a influência que a

102 Lira. Brasil sonoro. Generos e compositores populares. p. 115.

103 Ibid., p. 261.

104 Ibid., p. 28.

105 Barbosa. Samba: sua história, seus poetas, seus músicos e seus cantores. [1933] p. 17.

106 González e Rolle. Historia social de la música popular en Chile, 1890-1950. p. 186.

107 Bessa. «Um bocadinho de cada coisa»: trajetória e obra de Pixinguinha. História e música popular no Brasil dos anos 20 e 30. p. 151. 
música gravada estava tendo no campo. De fato, como assinalou Juan Pablo González, Carlos Vega:

pensaba que algunas de las cuecas que recolectó con Isabel Aretz en diversas regiones del centro y sur de Chile en 1942, debían haber llegado a oídos de sus informantes por conducto fonográfico, «pues los aparatos reproductores tienen enorme difusión en la campaña chilena» señala ${ }^{108}$.

Essa presença do gramofone e da rádio no campo é o que poderia explicar fenômenos como os analisados por José Geraldo Vinci do Moraes sobre "versões folclóricas" de música popular urbana, recolhidas e arquivadas pela Missão de Pesquisas Folclóricas em 1938. O autor deixa evidente a inclusão dos sambas Pelo telefone e Se você jurar entre as amostras de "folclore autêntico", e deixa claro o não reconhecimento de quem manejou o material ${ }^{109}$.

Quando a Missão de Pesquisas Folclóricas retornou a São Paulo, Mário de Andrade já não estava trabalhando no Departamento de Cultura e estava em vias de se mudar para o Rio de Janeiro. Portanto, não se tem segurança de que ele tenha conhecido todo o material recolhido pela Missão. Entretanto, como diz Moraes, seus discípulos, Martín Braunwieser e Oneyda Alvarenga, o conheceram bem e não tornaram explícito esse interessante cruzamento entre tradições.

Embora na bibliografia de Mário de Andrade não se tenha encontrado um escrito que denuncie um fenômeno semelhante, ele referiu-se a outro trânsito talvez mais habitual do que os folcloristas gostariam aceitar - entre a música erudita e a música popular. No Ensaio sobre a música brasileira (1928), notou que, em uma das toadas de Paraná que havia recolhido, era usada uma frase melódica da ópera $O$ Guarani, de Carlos Gomes, e deixou aberta a pergunta quanto a isso tratar-se de uma influência da música erudita no mundo rural ou de ter sido o compositor quem tomara essa melodia popular para sua obra110. No artigo "As bachianas" (1938), Mário de Andrade chamou atenção para as "estranhas e espantosas coincidências" que encontrou em um baião cujo início era uma mazurca do Chopin; entre um aboio e uma canção russa, e entre um maxixe e uma toccata de

${ }^{108}$ González e Rolle. Historia social de la música popular en Chile, 1890-1950. p. 187.

109 Moraes. "E «Se você jurar», «Pelo telefone», que estou na Missão de Pesquisas Folclóricas?".

${ }^{110}$ Andrade. Ensaio sobre a música brasileira. [1928] p. 134. 
Schumann ${ }^{111}$. Na capa do disco que contém a canção Prece (1930), de Alberto Costa e Luis Guaraná112, deixou escrito, com uma dose de ironia: "Si a «Prece» fosse assinada por Puccini, estaria entre as coisas boas dele, passagem da Manon Lescaut etc. O que mais ou menos prova que Puccini está ao alcance de todos"113. Inclusive, em 1941, mencionou também que, no Nordeste, encontrara o fox-trot That is my Baby convertido em coco ${ }^{114}$.

O trânsito entre a música erudita e a popular folclórica não é de surpreender se se tiver em conta que, desde o início da indústria discográfica, as gravações de ópera e música de concerto alcançaram vendas significativas, de modo que sua produção foi contínua a ponto de se difundir, não apenas entre os amantes do gênero, mas também ao ponto de chegar a lugares insuspeitados, conforme o caricato exemplo sonoro $\hat{O}$ de casa!, citado no início desta seção. Nesse sentido, também é sintomática a observação publicada em 1929 pela revista Phono-arte:

O invento do Edison fez [...] a divulgação da boa música, na massa pública, ao ponto de ficarmos estupefatos de vermos em centros verdadeiramente populares o sucesso da música clássica, quando não passados dez anos, elas eram completamente ignoradas ${ }^{115}$.

Talvez, esse tipo de influência entre a música erudita e a popular tenha surpreendido muito aqueles que, como Mário de Andrade e o crítico da Phono-arte, tiveram ouvidos para ouvir algumas delas.

Além disso, esse não parece ter sido um fenômeno isolado pois, também em Cuba, e em data até mais precoce, o compositor Gaspar Agüero encontrou na música popular de seu país similitudes com o repertório erudito. Em particular, ele chamou a atenção para o pregão "de un humilde vendedor de dulces", que percorria as ruas de Havana, cuja melodia era a mesma da ária "Pietà Signore", do italiano Alessandro Stradella (século XVII). Graças à maneira particular como Agüero entendeu a riqueza do repertório popular, argumentou que "aquel moreno dulcero, jamás en su

111 Andrade. "As bachianas." [1938] Música, doce música. Estudos da crítica e folclore, p. 274.

112 Prece, canção interpretada por Carmem Gomes, disco Victor N³3392 de autoria de Alberto Costa e Luis Guaraná, gravada em 1930.

113 Arquivo do Instituto de Estudos Brasileiros. Catálogo Discos Mário de Andrade.

114 Andrade. "O desnivelamento da modinha." [1941] Música, doce música. Estudos da crítica e folclore, p. 348 .

115 Revista Phono-Arte. "Futuro da música e música do futuro" n.18, 30 abril, 1929. p-1-2. Apud, Gonçalves. Música em 78 rotações: «Discos a todos os preços» na São Paulo dos anos 30. pp. 58-59. 
vida oyó tal" e esse era, segundo o autor, um exemplo de que "en lo recóndito de su ser, brillaba esplendente una llama de genio"116. Em 1923, outro colega, o compositor Sánchez de Fuentes, também disse que existia o costume, entre alguns compositores, de transpôr em "ritmo de danzón" melodias do repertório operístico e de zarzuela, o que qualificou como uma "equivocada tendencia"117.

Como se vê, os diálogos entre as tradições musicais, esquematicamente chamadas de urbanas, rurais e eruditas, eram muito mais frequentes, tensos e complexos do que a mera divisão taxonômica deixava perceber. Portanto, o artigo “A música e a canção populares no Brasil. Ensaio crítico-bibliográfico" foi um modo de Mário de Andrade chamar a atenção para as complexidades do ambiente musical brasileiro e, embora tenha atenuado a rigidez dos limites entre o urbano e o rural, não conseguiu sintetizar todos os cruzamentos que se davam entre os ambientes musicais.

Por outro lado, e mais ao sul de São Paulo, Carlos Vega vinha construindo um olhar particular a respeito da relação entre os meios rurais e urbanos, que acabaria dando origem ao seu enfoque teórico sobre o fenômeno popular. Em 1936, esse jovem pesquisador, em seu livro Danzas y canciones argentinas. Teorías e investigaciones, un ensayo sobre el tango, afirmou que, no seu entender: "Toda población menor está pendiente de la inmediata superior a cuya zona de influencia responde; y las superiores, de las que sobre ellas gravitan". Essa espécie de magnetismo fazia com que as cidades terminassem impondo seus usos "porque hay acuerdo tácito o expreso en que lo suyo representa el mejor hacer, el mejor pensar y el mejor sentir de la época". Na opinião de Carlos Vega, essa relação era fundamental, pois a cultura popular compunha-se de elementos citadinos que tinham chegado no passado e permaneciam, embora as cidades já tivessem mudado seus costumes. Além disso, Vega pensava que:

Las invenciones se transmiten tanto más rápidamente cuando más fluidas son las comunicaciones. Los pueblos menos accesibles, que pueden ser o no los más distantes, reciben con retardo o no reciben las nuevas invenciones. Así han permanecido, enquistados, pueblos que conservan las invenciones que muchos siglos antes fueron la más elevada expresión de prosperidad ${ }^{118}$.

\footnotetext{
p. 15 .

116 Agüero. Consideraciones sobre la música popular cubana: (a) sus defectos (b) sus bellezas.

117 Sánchez de Fuentes. El folk-lor en la música cubana. pp. 29-30.

118 Vega. Danzas y canciones argentinas. Teorías e investigaciones, un ensayo sobre el tango.
} pp. 26-27. 
Em 1944, no ano anterior à morte de Mário de Andrade, Carlos Vega publicou outro ensaio de matizes teóricas, em que criticou a "surdez" de alguns pesquisadores, que não ouviam o que a relação campo/cidade estava mostrando de forma tão evidente:

Los aficionados de las capitales, y los que, radicados en las ciudades del interior, estaban poseídos del pensamiento urbano, no prestaron la menor atención a todo aquello que en la campaña tenía sabor a ciudad. Una Polca o una Mazurka, bailadas en la Argentina por parejas rurales, no decía nada al observador aficionado; un Tango un Fox trot, ejecutados en la fiesta campesina, le indignaban. Concluía el compilador en la certeza de que «la civilización avanza» y lamentaba la pérdida de lo folklórico.

Naturalmente, esa es una manera como cualquier otra de no ver cómo llegan al pueblo las cosas que el pueblo adopta y conserva. Mientras los folkloristas se pierden en divagaciones sobre remotísimos orígenes populares hispánicos, indios, africanos, eclesiásticos o espontáneos, de nuestros canto y bailes, la realidad les está mostrando con precisión impresionante la principal fuente en que se nutre el pueblo: la ciudad capital ${ }^{119}$.

A situação criticada por Carlos Vega foi o que possivelmente aconteceu com as pessoas que manipularam o material recolhido pela Missão de Pesquisas Folclóricas no Brasil. A forma inovadora como Vega observou a música das cidades - livre de alguns dos prejuízos criados pela visão romântica —, levou-o a complementar o que Mário de Andrade tinha denunciado a respeito da realidade multifacetada e a pobreza da dicotomia campo/cidade. Graças ao diálogo musical entre o campo e a cidade que, ao que parece, Mário de Andrade presumia, ele pôde sentir que a separação entre uma música valiosa e camponesa e outra degradada e urbana era um parâmetro obsoleto, ao menos para o caso brasileiro e latinoamericano.

\section{A categoria música popular urbana}

Atualmente, parte da historiografia optou pela expressão música popular urbana para se referir à música popular que circula principalmente nas cidades e que, comumente, é transmitida pelos meios modernos de comunicação. Existe certo consenso entre os especialistas em usar esse termo para nomear o fenômeno musical que surgiu com a modernização das culturas urbanas no princípio do século XX.

119 Vega. Panorama de la música popular argentina. Con un ensayo sobre la ciencia del folklore. p. 39. 
Também na época de Mário de Andrade, essa expressão foi usada em algumas ocasiões, mas sem a carga teórica que tem agora.

Um dos primeiros autores que pensaram na necessidade de dar nome aos produtos das mudanças musicais citadinas foi o escritor Amadeu Amaral (1875-1929). Não é por acaso que Amaral foi um dos primeiros a pensar sobre o tema, pois é conhecida sua preocupação com estudo do português brasileiro e suas pesquisas dialetais. Em um escrito que não chegou a ser publicado em vida, Amaral afirmou que a categoria música popular não era suficiente para descrever os fenômenos musicais de seu tempo e, de forma precoce, criticou o uso que o romantismo fazia do termo. Para o escritor, existiam duas maneiras de entender o popular: "Para uns «popular» é tudo quanto corre entre o povo, mais ou menos anónimamente. Para outros, é aquilo que é produzido pelo próprio povo, ou melhor, feito por pessoas do povo e adotado por êste" ${ }^{120}$.

Sem se saber exatamente a data em que Amaral escreveu essas palavras, pode-se afirmar que, antes de terminar a década de 1920, existia no ambiente intelectual brasileiro alguma desconfiança a respeito da importância do anonimato como característica que definisse o popular, como se viu no capítulo anterior.

A seguir, Amaral deixou dito que, na realidade, nenhum dos dois usos de música popular servia para descrever o que acontecia em seu ambiente.

Qualquer desses critérios, aplicado à realidade dos factos, falha inmediatamente.

O primeiro peca por demasiado largo. Admite, por exemplo, no mesmo pé, a velha cantiga de berço espalhada por todo um país, repetida por gerações e gerações, e a última modinha inspirada numa ária de ópera ou num «fox-trot» norte-americano, que surgiu a se propagou momentáneamente num determinado lugar. Êsse critério deixa as coisas em completa confusão, e nada adiante desde o momento que se quer ver as coisas de perto e discernir uma das outras ${ }^{121}$.

Por outro lado, embora Mário de Andrade tenha considerado interessante a música que circulou nos aparelhos modernos de reprodução do som desde finais da década 1920, é importante esclarecer que somente dez anos depois a expressão música popular urbana passou a ser usada para se referir a um tipo de música diferente àquela chamada simplesmente de popular. Observa-se também que, depois que morou no Rio de Janeiro, em 1938, Mário de Andrade passou a usar com mais

\footnotetext{
${ }^{120}$ Amaral. "O popular em matéria folclórica." Tradições populares, p. 15.

121 Ibid.
} 
frequência essa expressão, junto às palavras submúsica e popularesco, para se referir ao que estava acontecendo no ambiente musical da capital.

Muito cedo, em sua obra, Mário do Andrade já tinha usado a expressão dança popular urbana para denominar o maxixe que era feito por Ernesto Nazareth, quando o músico morreu $(1926)^{122}$. Em 1930, usou a expressão música popular urbana ao assinalar que a música gravada no Brasil, aquela que era banalizada e desprezada, era popular urbana, e resgatou a gravação feita pela Odeon de Guaritã do coqueiro ( $\delta$ faixa 19) ${ }^{123}$ como peça “absolutamente admirável pela sua originalidade e caráter"'124. Nesse mesmo artigo, ele também mencionou outras gravações lançadas no mercado em 1929, como Vamos apanhar limão ( $\boldsymbol{f}$ faixa 20$)^{125}$ e Escoiêno noiva $(\boldsymbol{\delta} \text { faixa } 21)^{126}$. Nas capas de seus discos, o escritor também identificou como exemplo de música popular urbana a embolada Gato cabeçudo, gravada em 1929 ( $\boldsymbol{f}$ faixa 22$)^{127}$, acerca da qual escreveu: “Como embolada urbana, o Gato Cabeçudo é uma perfeição"128.

Uma década depois, em 1940, Mário de Andrade voltou a usar a categoria música popular urbana para se referir ao lundu e à influência que sobre ele tiveram os "pianeiros" que - segundo afirma Andrade - executavam música coreográfica e tocavam para a pequena burguesia para, pouco mais tarde, tocarem nas salas de espera dos primeiros cinemas. Segundo a introdução do artigo, este surgiu do entusiasmo despertado pela conferência feita por Brasílio Itiberê na Associação dos Artistas Brasileiros acerca do tema. Conforme conta Andrade, para o conferencista, os "pianeiros" foram os autores da mescla rítmico-melódica dos lundus e fados do Primeiro Império, com as polcas e habaneras importadas, e daí surgiram os maxixes 125.

122 Andrade. "Ernesto Nazaré." [1926] Música, doce música. Estudos da crítica e folclore, p.

123 Guaritã de coqueiro. Cantiga do norte do Brasil interpretada por Severino Rangel com os Batutas do Norte, discos Odeon Nº656, de autoria de Severino Rangel (Ratinho), gravado em 1930.

124 Andrade. "Gravação nacional." [1930] Taxi e crônicas no Diário nacional, p. 236.

125 Vamos apanhar limão. Toada nortista interpretada por Calazans com coro e seu grupo, discos Odeon Nº10398, de autoria de José Luis Rodrigues Calazans (Jararaca), gravado em 1929.

126 Escoiêno noiva. Moda da viola interpretada por Cornélio Pires e Caipirada Barretense, discos Columbia No20.021, de autoria de Cornélio Pires, gravado em 1929.

127 Gato cabeçudo. Embolada interpretada por José Luiz Rodrigues Calazans (Jararaca), discos Odeon $\mathrm{N}^{\circ} 10398$, de autoria de Calazans, gravado em 1929.

${ }^{128}$ Arquivo do Instituto de Estudos Brasileiros. Catálogo Discos Mário de Andrade. 
e tangos que, em 1880, consolidaram-se como música popular urbana carioca, até o surgimento do samba que os substituiu ${ }^{129}$.

No ensaio "Evolução social da música no Brasil” (1941), Mário de Andrade retomou os processos históricos dessa música urbana, sobre os quais tinha escrito no ano anterior, e assegurou:

Nos últimos dias do Império finalmente e primeiros da República, com a modinha já então passada do piano dos salões para o violão das esquinas, como o maxixe, com o samba, com a formação e fixação os conjuntos seresteiros dos choros e a evolução da toada e das danças rurais, a música popular cresce e se define com uma rapidez incrível... ${ }^{130}$.

Ao identificar que existia uma música urbana com certas características particulares, o autor paulistano ressaltou, como resultado da leitura do livro de Mariza Lira acerca da vida de Chiquinha Gonzaga, que esta compositora teve grande importância no desenvolvimento da música popular urbana, frase com a qual iniciou seu artigo de 1940, sobre a compositora ${ }^{131}$.

Além da atenção que Mário de Andrade parecia estar prestando à música popular da cidade em seus últimos anos, é possível que suas observações também tenham permeado seus interesses pela língua, posto que, em uma pequena nota da Folha da Manhã de 1944, caracterizou o uso da palavra trutas como uma "voz urbana do Brasil”, e fez um pequeno estudo acerca de seu significado ${ }^{132}$.

A ideia a respeito da existência de uma música popular urbana foi também exposta por Renato de Almeida na edição de sua História da música brasileira, de 1942. Na primeira parte do livro, dedicada à música popular, o autor referiu-se à existência de uma música popular brasileira nas cidades e propôs uma explicação histórica para sua formação.

Para Almeida, em tempos coloniais, os cantores populares foram mulatos e caboclos que, por não se encaixarem nos trabalhos da escravidão nem no lugar dos brancos, encontraram nas incursões pela selva e na vida das cidades seu lugar dentro

\footnotetext{
${ }^{129}$ Andrade. "Ernesto Nazareth." [1940] Música, doce música. Estudos da crítica e folclore.

130 Andrade. "Evolução social da música no Brasil." [1941] Aspectos da música brasileira, p. 24. p. 329.

${ }^{131}$ Andrade. "Chiquinha Gonzaga." [1940] Música, doce música. Estudos da crítica e folclore,

132 Andrade. "Do meu diário (B)." [1944] Música final. Mário de Andrade e sua coluna jornalística Mundo musical, p. 154.
} 
da sociedade. Então, segundo o argumento de Almeida, esses mestiços herdeiros dos sentimentos indígenas, negros e brancos, sublimaram suas tristezas na arte musical. O caboclo ficou vivendo no campo enquanto o mulato foi viver nas cidades, dando origem à música popular urbana que, ao que parece, Almeida reduzia à música popular do Rio de Janeiro. Com um argumento que buscou ser histórico, mas que não foi sustentado com documentação, Renato de Almeida associou a música popular urbana ao meio rural e, além disso, defendeu seu reconhecimento como legitimamente popular.

Não obstante, é importante esclarecer que esse popular urbano de Renato de Almeida não era tão amplo como a categoria que, ao que parece, era usada por Mário de Andrade. Almeida distinguiu abertamente o cantor popular urbano do cantor de broadcasting, alegando que este seria só um intérprete ${ }^{133}$. Na introdução de seu livro, explicou que esse cantor de broadcasting, por não ser o criador de uma melodia, mas sim um músico, deformava a versão espontânea da música popular e a enquadrava dentro das estruturas convencionais da música. Mas, de acordo com Renato de Almeida, se esse cantor ocasionalmente conseguisse manter a estrutura original, sua interpretação seria diferente daquela do cantor urbano popular legítimo.

Uma canção nordestina, fora da bôca do cantador natural, como nas reproduções urbanas, passa logo a interpretação e mesmo que seja possível manter a estrutura exata, o modo de cantar a deformará invariávelmente. [...]

Essa variação urbana tem contudo um grande inconveniente que é o da fixação artificial. O cantador não sabe música nem com ela se incomoda, êle é apenas um criador de canto, ao passo que o intérprete urbano enquadra a matéria que tomou em bruto nos limites das formas convencionais... ${ }^{134}$

Após a segunda edição do livro de Renato de Almeida, Mário de Andrade retomou a hipótese da origem histórica da música popular urbana exposta pelo amigo e a qualificou como "uma doutrina muito sedutora e plausível". Na resenha que publicou, o autor paulistano adicionou, de sua própria cepa, que quando a música “anônima do povo" foi-se impondo, durante o Império:

[...] os compositores urbanos semi-eruditos principiam se aproveitando dela na temática das suas quadrilhas e polcas, que coincidiam, na rítmica com o binário do

${ }^{133}$ Almeida. História da música brasileira. [1926] p. 149.

${ }^{134}$ Ibid., p. 5. 
povo nacional. E só ainda mais tarde é que estourará na música erudita e dentro de uma forma erudita $[\ldots]^{135}$.

Com essa interpretação hipotética do passado, Mário de Andrade conferiu um papel importante aos músicos urbanos populares enquanto mediadores entre a música popular de raiz folclórica e a música erudita, papel que ajudava a completar sua visão da relação entre o popular folclórico e o erudito, que sempre the interessou.

Por outro lado, outro de seus colegas mais jovens, Luiz Heitor Corrêa de Azevedo, também percebia, em fins da década de 1930, que a música popular realmente se dividia em dois tipos. Diferentemente de Mário de Andrade, Corrêa de Azevedo optou por se referir à música do campo com uma palavra especial — em vez de procurar uma denominação diferente para o fenômeno urbano - e usou o termo folcmúsica, com uma clara base no conceito de música popular dos estudos de folclore. Para esse autor, a música popular era uma "expressão móvel, fielmente representativa da alma brasileira"136 e, embora seu escrito não pareça fruto de uma profunda reflexão teórica, deixou dito em uma nota de rodapé:

Essa distinção [folcmúsica], é evidente, vale apenas como um artificio para tornar mais claro apenas o que venho expondo. No fundo folclore musical e música popular são uma e a mesma coisa, se fizermos questão da estrita significação verbal. Penitencio-me do abuso perante os rigoristas, para os quais as palavras têm mais valor do que as idéias... ${ }^{137}$.

O uso da palavra folcmúsica foi ocasional. Parece que foi um termo usado com maior frequência pelos estudos do folclore, pois uns anos depois Renato de Almeida e alguns autores hispanófonos também o empregarão.

Conforme foi assinalado por José Geraldo Vinci de Moraes, paralelo a esse movimento intelectual das décadas dos anos 1930, houve outro grupo de pessoas que documentou, por meio de crônicas, essa música popular urbana que era cada vez mais visível138. Entre os primeiros cronistas está o jornalista Orestes Barbosa que, em seu livro Samba: sua história, seus poetas, seus músicos e seus cantores (1933), disse que suas descrições do ambiente do samba eram suficientes para "caraterizar a

\footnotetext{
357.

${ }^{135}$ Andrade. "Música brasileira." [1942] Música, doce música. Estudos da crítica e folclore, p.

${ }^{136}$ Azevedo. Dois pequenos estudos de folclore musical. p. 15.

${ }^{137}$ Ibid., p. 18.

${ }^{138}$ Moraes, José Geraldo Vinci de. "História e historiadores da música popular no Brasil." Latin American Music Review. v. 28, no. 2 (2007).
} 
existência de uma música da cidade"139. Alem disso, convidava o leitor a passear com ele por todos os lugares onde "vive a alma do povo singular da cidade mais linda" ${ }^{140}$. É curioso que outro dos jornalistas que escreveram a respeito da história do samba, Francisco Guimarães (Vagalume), e que parece ter sido mais próximo dos músicos populares dos morros, não qualificou o samba como música popular em nenhuma linha de seu livro, tampouco como música popular urbana, denominando-o simplesmente pelo seu nome ${ }^{141}$.

Por sua vez, no âmbito hispano-americano não foram encontradas tantas referências à música popular urbana, com estas palavras nem com outros termos, como ocorreu no âmbito brasileiro ${ }^{142}$. Talvez não seja por acaso que tenha sido no México e na Argentina, dois dos países hispano-americanos que tiveram maior entrada na indústria fonográfica internacional, que foram encontradas duas menções à música popular urbana. Não obstante, estas duas referências surgiram por diferentes vias, de dois escritores muito diferentes e em dois momentos distantes.

De um lado, estava o médico nacionalista mexicano Miguel Galindo, que, como se viu no segundo capítulo, denominou-a de música popular citadina e a incluiu em uma classificação musical que fez em 1933.

Primeiro, Galindo esclareceu que as principais categorias em que se podia dividir a música de seu ambiente eram música erudita, popular, camponesa e indígena, e que suas fronteiras não eram absolutas, mas sim "un tanto convencionales". De acordo com sua explicação, a música erudita era "en su mayor parte, extranjera, pues ella viene solamente con la ayuda de la técnica"; a música camponesa era "propia de los mestizos, la música híbrida desgraciadamente abandonada a los pequeños poblados, a las alquerías y rancherías"; a música

139 Barbosa. Samba: sua história, seus poetas, seus músicos e seus cantores. [1933] p. 14.

140 Ibid.

${ }^{141}$ Guimarães. Na roda do samba. [1933].

${ }^{142}$ Esporadicamente, Francisco Curt Lange usou a expressão música popular crioula para denominar a música camponesa. Em espanhol, a palavra criollo teve várias acepções: por um lado, serviu para designar os descendentes de europeus ou africanos nascidos em território hispanoamericano e, por outro, usou-se para denominar o "nativo, próprio de um país hispanoamericano" (Lange, Francisco Curt. "Sistemas de investigación folklórica y el empleo del acervo folklórico en la música artística." Boletín Latinoamericano de música. v. II, (1936) p. 150.).

Em 1930, o equatoriano Segundo Moreno também usou a expressão música crioula para se referir à música popular como música nativa de seu país (Moreno. "La musica en el Ecuador." El Ecuador en 100 años de independencia, pp. 211-215.). 
indígena era, "con toda exactitud, la de los pueblos indígenas que se ha conservado", e a música popular era "la parte más indecisa" por "ser al mismo tiempo erudita y popular". Conforme explicou:

[...] la música popular es semi-erudita, en cuanto a que originalmente está escrita y es estudiada en las grandes poblaciones por los músicos que tienen conocimientos teóricos de la notación y del solfeo; es semi-popular, no tanto porque es en los pueblos de mediana o grande importancia en donde se usa, sino también, y principalmente, porque en aquellos ya los músicos que la aprenden lo hacen sin conocimientos teóricos, guiados ante todo, por el sentimiento genuino de la raza, $[\ldots]$

Esta pues, que seguiremos llamando música popular o citadina, en unión de la campesina, es la base de nuestro arte nacional futuro ${ }^{143}$.

Por outro lado, e saindo da cronologia do presente trabalho, é interessante mencionar Carlos Vega e seu conceito de mesomúsica. De acordo com o musicólogo uruguaio Coriún Aharonián, em 1965 e pouco antes de sua morte, Carlos Vega apresentou na Segunda Conferencia Interamericana de Musicologia, em Bloomington (Estados Unidos), uma exposição em que propôs o conceito de mesomúsica para denominar a essa música que:

...es el conjunto de creaciones funcionalmente consagradas al esparcimiento (melodías con o sin texto), a la danza de salón, a los espectáculos, a las ceremonias, actos, clases, juegos, etcétera, adoptadas o aceptadas por los oyentes de las naciones culturalmente modernas. Durante los últimos siglos el mejoramiento de las comunicaciones ha favorecido la dispersión de la mesomúsica de tal manera, que hoy sólo se exceptúan de su influjo los aborígenes más o menos primitivos y los grupos nacionalizados que aun no han completado su ingreso a las comunidades modernizadas ${ }^{144}$.

De acordo com Aharonián, a exposição de 1965 é de grande valor porque mostrou, por vez primeira, a necessidade de se estudar um tema que a musicologia daquele momento não contemplava. Além disso, na opinião do autor, a exposição de Vega ofereceu um termo suspicaz que definia um terreno por pesquisar, além de ser posto sobre bases de estudo sérias ${ }^{145}$. Nessa exposição, que foi pouco discutida em seu tempo, Vega começou denunciando a falta de terminologia para falar de todas as classes de música existentes e das ambiguidades que o conceito de música popular encerrava - com o que Amadeu Amaral concordaria, como foi mencionado. Também lançou uma caracterização musical esquemática da mesomúsica, que estaria

${ }^{143}$ Galindo. Nociones de la historia de la música mejicana. pp. 409-410 [grifos nossos].

${ }^{144}$ Vega, Carlos. "Mesomúsica. Un ensayo sobre la música de todos." Revista Musical Chilena. v. 51 , no. 188 (1997) p. 78.

${ }^{145}$ Aharonián. "Carlos Vega y la teoría de la música popular. Un enfoque latinoamericano en un ensayo pionero." 
presente desde o século XII. Além disso, propôs a mesomúsica como o modo por excelência para se educar, sendo também a detentora da maior importância econômica no mundo ${ }^{146}$.

No capítulo anterior, viu-se que, durante os anos de vida de Mário de Andrade, Carlos Vega tinha demonstrado que, para ele, os fenômenos musicais urbanos não deviam passar por alto na pesquisa musical. Não obstante, seria interessante estudar a gênese de seu conceito de mesomúsica em relação ao entendimento que Vega teve da música popular urbana midiatizada para continuar com a história do conceito de música popular nas décadas seguintes à morte de Mário de Andrade.

Por outro lado, embora a morte prematura de Mário de Andrade não permita saber até que ponto teria chegado seu interesse pela música popular urbana, seus trabalhos podem ser vistos como uma ponte entre o desinteresse característico de seu tempo e a notoriedade que agora esse tema tem como objeto de estudo acadêmico.

\section{Prevenção e desprezo pela música popular urbana}

O interesse pelo estudo da música popular urbana, de um ponto de vista acadêmico, é uma das características da historiografia musical mais recente. Há consenso em afirmar que, na época de Mário de Andrade, a música popular das cidades e que circulava em discos e rádio não era considerada possuidora de valores estéticos nem sociais que a tornassem um objeto de estudo interessante para os intelectuais do momento. Não obstante, sabe-se que aqueles acadêmicos não desconheciam essa música, pois ela ocupava, cada vez mais, lugares importantes nos cenários e nos meios eletrônicos de difusão, como se mencionou. Existem até mesmo indícios de que, no Brasil, certa elite intelectual a tenha desfrutado em seus saraus musicais, em que gêneros como o samba foram cantados e aplaudidos ${ }^{147}$. Em resumo, parece que, da boca para fora, os intelectuais das primeiras décadas do século XX opinavam que os músicos populares urbanos eram pessoas analfabetas que inventavam música vulgar e sem valor ${ }^{148}$. Além disso, cunharam alguns termos

\footnotetext{
146 Vega. "Mesomúsica. Un ensayo sobre la música de todos."

147 Viana. O mistério do samba.

${ }^{148}$ Contier. Brasil Novo. Música, nação e modernidade: os anos 20 e 30. p. 384.
} 
depreciativos para diferenciar a música popular folclórica daquela outra música popular de que desfrutavam ao calor de uma cachaça com os amigos. A seguir, serão revisados três desses termos: populachera, usado ocasionalmente em espanhol, e submúsica e popularesca, usados no Brasil.

Em espanhol, alguns autores usaram o adjetivo populachera para se referir pejorativamente à música que se ouvia nos alto-falantes dos gramofones e rádios, e que era diferente da que cotidianamente se chamou de popular ou folclórica.

O médico mexicano Miguel Galindo usou essa expressão para desqualificar um tipo de música que considerava ser de baixa qualidade, que era difundida pelos meios eletrônicos modernos de comunicação e que, quando se mesclava com a música "exótica" mexicana, punha "en ridículo nuestra manera de ser, para presentar nuestro arte en caricatura". De acordo com esse autor, o antigo costume de cantar a música popular de seu país caiu em desuso por culpa do gramofone:

[...] No escapa a esta innata tenencia la sirviente de la casa que prepara la alimentación de los amos o arregla la recámara tarareando algún cantarcillo en que siente palpitar ilusiones o recuerdos. Estas costumbres se van reduciendo con la invasión fonográfica porque, en vez de cantar, artesanos o trabajadoras domésticas ponen a gritar el aparato que ejecuta la música que está en el disco que se compró a instancias de hábil agente, música populachera, y ramplona si es nacional, que pone en ridículo nuestro arte verdadero, o música exótica ${ }^{149}$.

Parece que o uso do adjetivo populachera denunciava três coisas: o reconhecimento de uma música similar, mas não igual à popular folclórica; a circulação em discos dessa música; a baixa qualidade que lhe era atribuída e, sobretudo, a necessidade quase inconsciente que se sentiu de dar um nome especial a esse novo gênero.

Na Colômbia, Emirto de Lima, na década de 1930, parece ter concordado com seu colega mexicano quando qualificou como populachera certa música popular. Este compositor, defensor da música nacional colombiana e da rádio, sentiu necessidade de diferenciar dois tipos de música popular, uma de natureza aceitável e outra absolutamente reprovável. Antes de fazer essa diferenciação, referiu-se ao trabalho dos arranjadores, que tomavam nas mãos qualquer música popular e a deformavam, acreditando que a estavam estilizando, "porque de unos años para acá, el verbo estilizar se ha puesto muy en voga y todo el mundo se siente con derecho a

${ }^{149}$ Galindo. Nociones de la historia de la música mejicana. p. 34 [grifos nossos]. 
escribir estilizaciones, posea o no las facultades necesarias". Feita esta elucidação, Emirto de Lima explicou ao seu público que essa prática estava gerando grandes confusões:

La mayoría de las gentes creen que la música ligera es la música verdaderamente popular. Hay, desde luego, mucha música ligera que ha obtenido la popularidad fácilmente, pero que dista muy lejos de ser la pura expresión del pueblo. Es necesario establecer la diferencia entre una y otra. La primera es populachera, música de cabaret, de los dancings, degenerada, sensual, trivial y frecuentemente vulgar $^{150}$.

Para esclarecer sua explicação, Emirto de Lima ofereceu alguns exemplos sonoros da "verdadeira" música popular, aquela criada pelas "masas ignoradas para cantar sus fiestas religiosas y cívicas, para celebrar sus acontecimientos privados o cívicos, como bautizos, matrimonios, ceremonias fúnebres, juegos, etc.”. Ao que parece, sua conferência foi ilustrada por um coro que cantou cinco peças acordes com esta descrição. Para exemplificar essa outra música popular, ou melhor, populachera, a que se referiu, ele disse:

Hay una enorme diferencia entre estas producciones, finas unas, suaves otras, tiernas y sentimentales muchas, alegres y sanas, una buena mayoría, y las antiestéticas canciones que a diario escuchamos por esas calles de Dios con los rótulos de Compaegallo, Yo no le dije ná, Te lo ví, y otras músicas de pésimo gusto, que no quiero nombrar ahora para no dañar el ambiente de distinción que reina en esta sala ${ }^{151}$.

As três canções citadas como "de péssimo gosto", provavelmente vinham sendo difundidas em Barranquilha por meio de discos de 78 rpm e de estações de rádio comerciais. A primeira peça pode tratar-se da guaracha Cuidadito compay gallo, do músico cubano Antonio Fernandez (Nico Saquito) que, ao que tudo indica, foi muito vendida porque foi gravada pela Columbia em 1936 e, no ano seguinte, pela discos Victor ( $\boldsymbol{f}$ faixa 23$)^{152}$. Yo no le dije ná pode ser o bolero do portoriquenho Rafael Hernandez (O Jibarito), gravado em Nova Iorque pela Discos Victor em 1935 ( $\delta$ faixa 24) ${ }^{153}$; e Te lo ví pode tratar-se do son composto pelo panamenho Ricardo Fábrega e gravado pela Discos Victor em 1934, em Nova Iorque. As três obras eram música estrangeira, difundidas pelas maiores companhias discográficas e

150 Lima. Folklore colombiano. pp. 152-153 [grifos nossos].

151 Ibid.

152 Cuidadito compay gallo. Son interpretado por Panchito Riset e Quarteto Caney, discos Columbia No5514-X, de autoria de Antonio Fernandez (Nico Saquito), gravado em 1936, em Nova Iorque.

153 Yo no le dije ná. Bolero interpretado por Grupo Victoria y Pedro Ortíz-Dávila, discos Victor $\mathrm{N}^{\mathrm{o}} 32522$, de autoria de Rafael Hernandez (El Jibarito), gravado em 1935 em Nova Iorque. 
com textos de duplo sentido que, na realidade, não se afastavam da tradição hispânica da música cantada, na qual as temáticas "apimentadas" tinham um antigo uso $^{154}$.

No caso brasileiro, é importante ter em conta que, quando Mário de Andrade vivia no Rio de Janeiro e esteve mais perto do surgimento do samba como música nacional - pelas mãos da indústria discográfica e da elite intelectual e política ${ }^{155}$-, qualificou a música gravada como uma "espécie de submúsica", e usou as famosas palavras que dão título ao presente capítulo. Como se verá, essa frase foi citada inúmeras vezes pela historiografia posterior para demonstrar o desprezo que Mário de Andrade sentia pela música gravada.

Por meio da leitura da obra publicada do autor, observou-se que o qualificativo de submúsica foi usado com um claro caráter pejorativo, não só para a música gravada, mas também em geral, para "esse gênero que consegue o aplauso fácil das pessoas fáceis", que também se encontrava na música erudita ${ }^{156}$. Segundo Mário de Andrade, a submúsica surgia em duas situações: quando a música gravada adotava soluções fáceis para se tornar comercial e quando a música erudita confundia o virtuosismo com a musicalidade e se tornava espetáculo circense ${ }^{157}$. Isso significaria que o fato de chamar de submúsica certa música gravada não partia de um preconceito em torno dos fenômenos midiáticos. Provavelmente, submúsica tinha outra conotação pois, com esta mesma palavra, também denominou algumas obras do repertório erudito que caíram em um de seus mais denunciados vícios: o

154 Bermúdez, Egberto. "Del humor y el amor: música de parranda y música de despecho en Colombia (II)." Cátedra de Artes. no. 4 (2007).

155 Viana. O mistério do samba.

156 Andrade. "Nacionalismo musical." [1939] Música, doce música. Estudos da crítica e folclore, p. 296.

157 Sobre o tema do virtuosismo e as críticas que Mário de Andrade fazia ao "facilismo" na música acadêmica, ver suas resenhas de concertos. 
virtuosismo ${ }^{158}$. Esse "aplauso fácil" provavelmente ficaria ilustrado com o exemplo do samba Mulambo, já mencionado ( $\int$ faixa 11).

Entretanto, longe do uso que Mário de Andrade fez do termo submúsica poucas vezes utilizado - , é notório que, com o passar dos anos, o escritor paulistano fez críticas cada vez mais fortes à música e aos músicos que o rodeavam, tanto do meio popular quanto do meio erudito. No início da década de 1940, quando sua maior preocupação era o compromisso social da arte, leem-se críticas como a seguinte, feita à música dos meios de comunicação ao cotejá-la à música de Chiquinha Gonzaga:

ela pertence a um tempo em que mesmo a composição popularesca, mesmo a música de dança e das revistas de ano ainda não se degradaram sinicamente, procurando favorecer apenas os instintos e sensualidades mais reles do público urbano de hoje $\mathrm{j}^{159}$.

Opiniões como a anterior foram lidas por outros estudiosos da música popular e, em geral, posteriores a Mário de Andrade, para justificar o profundo desprezo que esse tipo de música merecia. Além disso, é possível que a fortuna crítica acabasse transpondo toda a carga pejorativa da categoria submúsica para outro termo que o autor também usou em relação à música popular: música popularesca ${ }^{160}$.

A historiografia musical costuma afirmar que o interesse de Mário de Andrade pelo popular restringiu-se à música rural, longe dos processos de modernização, e a alguns gêneros urbanos, como a modinha e o maxixe. Conclui-se, habitualmente, que ele desprezou a música difundida pelos meios de comunicação da época e assume-se que o termo popularesco denominava pejorativamente esse tipo

158 Talvez a repugnância ao virtuosismo tenha alguma explicação na vida pessoal de Mário de Andrade. Segundo Gilda de Mello e Souza, prima do autor paulistano, durante a infância ele competia com o irmão menor, Renato, por alcançar lucros virtuosos no piano e, com eles, a admiração da família. Mas a morte súbita de Renato, quando Mário de Andrade tinha 19 anos, provocou-lhe uma crise nervosa que o deixou com um tremor nas mãos e truncou sua carreira de pianista concertista. Durante o tempo que levou para se recuperar dessa crise nervosa, diz Mello e Souza, morreu o músico virtuoso e nasceu o poeta: "o escritor renascido da morte simbólica - que implica a renuncia à música, e na qual o pianista se transforma no professor de piano e o virtuose, no intelectual empenhado e virtuoso - será sempre o sobrevivente culpado de uma catástrofe a redimir..." (Wisnik. "O ensaio impossível." Gilda, a paixão pela forma, p. 214.) p. 331.

${ }^{159}$ Andrade. "Chiquinha Gonzaga." [1940] Música, doce música. Estudos da crítica e folclore,

160 A palavra popularesca contém o sufixo "esca" que também é usado em palavras como arabesco, pitoresco e quixotesco. O sufixo "esco" provém do latim e passou para o português, espanhol e italiano para indicar algo que tem ligação com o substantivo do qual deriva, mas com certo tom de pilhéria e, algumas vezes, com um matiz depreciativo. Particularmente em português, popularesco define algo que pretende ter caráter popular. 
de música. Não obstante, a leitura cuidadosa de parte de sua obra indicou que o significado dessa palavra nem sempre foi o mesmo, mas mudou ao longo do tempo e à medida em que os fenômenos culturais desenvolveram-se, como se verá mais adiante.

Jorge Coli (1972) compreendeu o uso do adjetivo popularesco dentro do pensamento de Mário de Andrade como um termo que se referia à "música vinda de cima para baixo, do artista erudito para a massa «ignara»" e inserida dentro do que Andrade descreveu como a consequência do "pontapé de Mozart". Com essa metáfora, cunhada na década de 1940, Mário de Andrade referia-se às consequências trazidas para os músicos europeus sua renúncia em servir à aristocracia a partir do final do século XVIII, optando por se tornarem populares — populares no sentido de ser capitalistas, porque assinavam e vendiam sua música em busca da aceitação do grande público ${ }^{161}$.

Embora seja certo que na década de 1940 o "pontapé de Mozart" tenha sido uma interpretação recorrente na obra de Mário de Andrade, o uso de popularesco não esteve diretamente relacionado com ela, pois o termo surgiu em escritos anteriores e de acordo com outras preocupações. $\mathrm{Na}$ realidade, popularesco foi uma palavra usada desde suas primeiras publicações para descrever diferentes tipos de música, e não só a música gravada, como habitualmente se afirma.

Em 1988, o historiador Arnaldo Contier entendeu a expressão música popularesca na obra de Mário de Andrade como música popular urbana usada para o consumo imediato, e oposta ao popular-folclórico ${ }^{162}$. Em síntese, essa vem sendo a interpretação habitual dada ao termo pela historiografia. Contier é um dos historiadores mais influentes na atual historiografia musical brasileira, e sua denúncia do sentido pejorativo de popularesco foi argumentada convincentemente por intermédio da reconstrução histórica do contexto social e político em que Mário de Andrade viveu ${ }^{163}$. De um ponto de vista historiográfico, a leitura de Contier ajudou a explicar o abandono que a música popular urbana sofreu por parte da academia brasileira durante grande parte do século XX, pois o fato de ter sido marginalizada

161 Coli. "Mário de Andrade - Introdução ao pensamento musical." p. 131.

162 Contier. Brasil Novo. Música, nação e modernidade: os anos 20 e 30. p. 536.

163 Ibid., p. 171. 
por um dos intelectuais mais importantes da primeira metade do século XX explicava que a academia posterior se mantivesse receosa em relação ao tema ${ }^{164}$.

Por outro lado, tudo parece indicar que as leituras indiretas da obra de Mário de Andrade ajudaram a dar continuidade à leitura proposta por Contier. Outros autores um pouco anteriores a Contier, como Vasco Mariz e Renato de Almeida, também tinham usado em seus escritos a expressão música popularesca com a intenção de menosprezar a música urbana midiatizada ${ }^{165}$ e, talvez por isso, não surpreendesse aos leitores de finais do século XX o uso da expressão ilustrada por Contier.

Um exemplo dos mal-entendidos acerca do pensamento musical de Andrade é a famosa citação de suas palavras a respeito da música de rádio e dos discos já mencionada:

Mas o que aparece nestes concursos, não é o samba do morro, não é coisa nativa nem muito menos instintiva. Trata-se exatamente de uma submúsica, carne para alimento de rádios e discos, elementos de namoro e interesse comercial, com que fábricas, empresas e cantores se sustentam, atucanando a sensualidade fácil de um público em via de transe $[\ldots]^{166}$.

Entre outros autores, Márcio de Souza usou essa citação em sua tese de doutorado para exemplificar o mencionado menosprezo de Mário de Andrade. Souza afirmou que essas palavras foram pronunciadas pelo autor em uma conferência de 1934 quando, na realidade, foram escritas em um artigo de 1939 ${ }^{167}$. A inexatidão da sua citação explica-se porque Souza não conheceu o artigo original de Mário de Andrade, mas tomou a citação e sua interpretação do livro $O$ violão azul: modernismo e música popular, de Santuza Cambraia Naves ${ }^{168}$. Por sua vez, Santuza Cambraia Naves tampouco leu o original de Mário de Andrade, mas tomou a

164 Moraes, José Geraldo Vinci de. "«Samba tem cadência. Digo a verdade. E até já chegou na universidade»." In: Francisco José Gomes Damasceno (ed.), Experiencias musicais, Fortaleza: Prefeitura Municipal de Fortaleza - PMF / EDUECE, 2008, pp. 30-31.

165 Após a morte de Mário de Andrade, Renato de Almeida usou a expressão música popularesca para de denominar "as melodías de caráter efêmero e finalidades comerciais, como as de carnaval" (Almeida. "Música folclórica e música popular." p. 8).

${ }^{166}$ Andrade. "Música popular." [1939] Música, doce música. Estudos da crítica e folclore, p. 281

167 Souza, Márcio de. Mágoas do violão: mediações culturais na música de Octávio Dutra (Porto Alegre, 1900-1935). (Teses) PUCRS, 2010.

168 Naves, Santuza Cambraia. O violão azul: modernismo e música popular. Rio de Janeiro: Brasil Fundação Getulio Vargas Editora, 1998, p. 48. 
informação da resenha que Vasco Mariz fez sobre a vida e obra do autor, em $1983^{169}$. Ao ler o texto de Mariz fica evidente que o autor não ofereceu os dados bibliográficos da citação e que, além disso, deu uma interpretação conveniente às palavras do famoso intelectual. Graças à comparação sugestiva que Mariz fez entre a música de rádio da época de Andrade e o consumo televisivo de sua própria época, parece que sua citação procurava denunciar a baixa qualidade da música difundida pelos meios de comunicação, especialmente a televisão, e não o pensamento de Mário de Andrade. Na história das ciências, é comum esse tipo de argumentação que põe na boca de autores mortos e de amplo reconhecimento acadêmico, posturas polêmicas contemporâneas para tentar resolver tensões de seu presente.

A excessiva prevenção atribuída a Mário de Andrade contra a música popular urbana e midiática tem bases históricas que remontam aos inícios do século XX. Independentemente das apreciações de nosso autor, é sabido que a nova música incomodou por diversos motivos uma parcela da população nas cidades. Como bem ilustrou Camila Koshiba Gonçalves, desde a década de 1920, surgiram críticas e inconformismo em relação aos sons de gramofones e rádios nas ruas das cidades brasileiras. Tanto no Rio de Janeiro quanto em São Paulo, criticou-se o alto volume dos aparelhos, que contribuíam para o barulho das cidades. Na opinião da autora, essas denúncias podem ter estado relacionadas também ao menosprezo que alguns jornalistas expressaram pela música "desprovida de harmonia, barulhenta, impregnada de percussões violentas, de dissonâncias estranhas" que "encontra uma larga e vasta aceitação", segundo palavras de um dos comentaristas da Phono-Arte em $1930^{170}$.

Para se compreender melhor esse sentimento de prevenção em relação à nova música, pode-se recordar que uma das características da visão de mundo romântica foi seu temor e crítica à quantificação do mundo ou "envenenamento da vida social pelo dinheiro", entre outros aspectos ${ }^{171}$. No mundo musical, essa crítica tomou forma ao menosprezar a música feita para ser vendida, principalmente aquela

169 Mariz, Vasco. Três musicólogos brasileiros. Mário de Andrade, Renato Almeida, Luiz Heitor Correa de Azevedo. Rio de Janeiro/ Brasília: Civilização Brasileira; Instituto Nacional do Livro, 1983, p. 43.

170 Phono-Arte. “Amplificações e sonoridades” n, 15, 15 jan. 1930. s/p Apud. Gonçalves. Música em 78 rotações: "Discos a todos os preços» na São Paulo dos anos 30. p. 125.

${ }^{171}$ Löwy e Sayre. Revolta e melancolia. O romantismo na contramão da modernidade. 
dirigida ao crescente público amador que procurava diversão. Embora esse não tenha sido um fenômeno próprio do século $\mathrm{XX}$, pois já no século anterior deu-se a comercialização de música fácil em partituras soltas, este parâmetro foi continuado pela empresa discográfica, ávida de lucros comerciais, e as denúncias relativas a essa situação não tardaram ${ }^{172}$.

Tanto o desprezo à relação entre criação musical e mercado quanto a prevenção contra os meios mecânicos de reprodução do som, permearam o conceito de música popular e alimentaram a ideia de que se tratava de uma música inferior e desprezível, por trazer dentro de si duas particularidades reprováveis da modernidade capitalista, segundo a visão romântica: o dinheiro e a máquina

Nesse sentido, chama a atenção a história que Mariza Lira contou em 1938, em que se percebe a existência do mito da criação espontânea e legítima no mundo da música popular ou, como o chamou o musicólogo Nicholas Cook, o "mito da autenticidade"173. Para explicar a composição da marcha Pé de Anjo, de José Barbosa da Silva (Sinhô), gravada pelos selos Odeon e Popular, e usada em uma revista de teatro de grande sucesso, a autora contou que:

[...] uma tarde, quasi ao fechar das lojas, entra em uma casa de músicas da rua do Ouvidor, onde Sinhô fazia ponto, uma senhora à procura de uma valsa que ouvira, mas, de que não sabia o nome.

O único recurso foi trautear, imprecisamente, aliás, um trecho da valsa que lhe ficar na memória. Isso pouco adiantou ao vendedor, que gentilmente pediu para que a fraguesa repetisse a toada. Sinhô ao lado, junto ao piano, pegou imediatamente a melodia, tocando-a em meia dúzia de notas.

Só então o vendedor reconheceu a valsa francesa Geny, em grande moda no momento. Sinhô displicentemente, continuou ao piano a insistir nas notas que fixara. De repente completou uma frase musical, amplio-a, pô-la em ritmo de marcha, e uma linda música vibrou no ar. Radiante virou-se para o vendedor, um grande amigo seu e disse: - Sabes, vou chamá-la Pé de Anjo! Vi, agora, um desafeto e achei profundamente ridículo o tamanho de seus pés. Vingar-me-ei

\footnotetext{
${ }^{172}$ As consequências da visão romântica sobre a relação música/mercado foram profundas, pois se criou uma escala de valores cuja vigência chega até o presente. Por exemplo, diferenciou-se o músico que compunha segundo suas necessidades criativas internas - uma imagem tipicamente romântica - de quem compunha para satisfazer as expectativas econômicas do mercado. Na realidade, não foi um fenômeno moderno o fato de o músico compor premido por uma demanda, pois já há muito tempo os compositores desenvolviam sua atividade segundo as exigências de seus mecenas. $\mathrm{O}$ que era novo no mundo capitalista era que as monarquias e elites eclesiásticas não eram os únicos patrocinadores da atividade artística, e que os comerciantes começavam a ser melhores patrocinadores e a pagar ao compositor com dinheiro, e não com comida, moradia e prestígio, como se fazia nos sistemas pré-capitalistas.

173 Cook, Nicholas. De Madonna al canto gregoriano. Una muy breve introducción a la música. [1998] Madrid: Alianza editorial, 2001.
} 
escarnecendo-lhes as bases. Mas os versos? Pensou... ora os versos, arrajam-se... Foi assim que surgiu o Pé de Anjo ${ }^{174}$.

O relato fabulado da Mariza Lira permite perceber que a historiografia da música popular urbana compartilhou com a visão de mundo romântica, a importância da criação espontânea, e criou lendas que, assim como na historiografia da música erudita, apresentavam os momentos de inspiração e genialidade dos músicos biografados, talvez tentando dissimular as políticas econômicas que estavam por trás da música que era gravada e vendida.

\section{A música popularesca de Mário de Andrade}

É difícil definir se o uso da palavra popularesco, para qualificar certo tipo de música, foi cunhado por Mário de Andrade ou por algum outro autor. Na literatura brasileira consultada, não se encontraram escritos anteriores em que a palavra tenha sido usada, mas ficou aberta a possibilidade de que ele tenha adotado esse termo de um de seus mais interessantes colegas europeus, Béla Bartok ${ }^{175}$.

De acordo com o etnomusicólogo italiano Marco Lutzu, na tradução para o italiano do artigo de Bartok, "Mi a népzene," (O que é a música popular?), publicado originalmente na revista $U j$ Idök, de Budapeste, em 1931, a expressão música popularesca foi usada ${ }^{176}$. Ao se consultar a tradução espanhola do mesmo artigo, verificou-se que esse adjetivo também foi usado para se referir à “ música popular ciudadana". Além disso, é interessante observar que, nesse escrito, Bartok dizia que a música popular era composta por dois tipos de música: a música da cidade e a música das aldeias.

Podemos llamar música popular ciudadana o música culta popularesca, a aquellas melodías de estructuras más bien simples, compuestas por autores dilettantes pertenecientes a las clase burguesa y, por ello, difundidas sobre todo en la clase burguesa. Esas melodías, en cambio, no son conocidas por la clase campesina o, a lo sumo, han penetrado en ella sólo relativamente tarde y siempre a través de la «mediación» de la burguesía ${ }^{177}$.

Nesse artigo, Bartok atribuiu um valor "incomparavelmente superior" à música das aldeias camponesas em relação à música culta popularesca, porque a

\footnotetext{
${ }^{174}$ Lira. Brasil sonoro. Generos e compositores populares. p. 197.

175 Agradeço as conversas com a professora Flavia Camargo Toni a respeito.

176 Comunicação pessoal (La Habana, 4 de nov. de 2010) e e-mail (17 de nov. de 2010).

${ }^{177}$ Bartok, Bela. Escritos sobre música popular. México: Siglo XXI, 1985, p. 66.
} 
música camponesa "no es, en el fondo, otra cosa que el producto de una elaboración cumplida por un instinto que actúa inconscientemente en los individuos no influídos por la cultura ciudadana"178.

Apesar de Elizabeth Travasso, em sua pesquisa a respeito de Mário de Andrade e Béla Bartok, afirmar que esses dois musicólogos não tiveram contato ${ }^{179}$, pôde-se estabelecer que Mário de Andrade conheceu uma pequena parte do trabalho do músico húngaro graças aos indícios que deixou em seu «fichário analítico». A maioria das notas sobre Bartok estão relacionadas com suas composições, e só uma papeleta faz referência ao artigo "La musique populaire Hongroise", publicado em La Revue Musicale, de 1921. Nesse escrito, dez anos antes do ano já citado, Bela Bartok usou a palavra francesa semi-populaire, que se traduziria literalmente como semi-popular, e que foi usada pelo autor para explicar os tipos de música que existiam entre os camponeses de seu país:

Por otra parte, se puede muy bien contar entre las melodías llamadas populares, ciertas melodías semi-populares de aficionados, cantadas no por algunos individuos sino por toda clase de campesinos, y esto, durante un periodo de tiempo más o menos largo ${ }^{180}$.

Mais adiante, Bartok explicou, a respeito dessa música semi-populaire, que:

Se confunden a menudo las melodías populares propiamente dichas con las melodías semi-populares de aficionados. Los autores de estas últimas disponen de una cierta cultura musical, importada, en general, de la ciudad; la mayoría son músicos aficionados; también en las melodías de su invención mezclan ciertos lugares comunes occidentales con ciertas particularidades exóticas de su propia música popular ${ }^{181}$.

Além das semelhanças entre as colocações do autor húngaro e as circunstâncias com as quais Mário de Andrade deparou-se em seus estudos sobre a música popular brasileira, o mais interessante desse artigo é que se tem certeza de que Mário de Andrade o leu com atenção, posto que, além de sua referência no «fichário analítico», fez uma anotação a respeito de uma menção de Bartok aos elementos não populares na música de Franz Liszt e Johannes Brahms. É difícil medir o impacto que esse escrito teve no pensamento do musicólogo brasileiro, mas

178 Bartok. "¿Qué es la música popular?" [1931] Escritos sobre música popular, p. 68.

179 Travassos, Elizabeth. Os mandarins milagrosos. Arte e etnografia em Mário de Andrade e Béla Bartok. Rio de Janeiro: Funarte e Jorge Zahar Editor, 1997.

180 Bartok, Bela. "La musique populaire Hongroise." La Revue Musicale. v. Deuxième Année, no. 1 (1921) p. 10.

181 Ibid. 
se intui que sua leitura não foi paradigmática, dadas as poucas notas marginais que deixou em seu exemplar. Além disso, não é possível afirmar que Mário de Andrade tenha tomado semi-populaire e traduzido como popularesco, pois, para um escritor como ele, com grandes dotes literários e um manejo criativo do idioma, não seria difícil cunhar a palavra por si mesmo.

Além disso, se Mário de Andrade leu o artigo da Bela Bartok próximo ao ano da sua publicação, 1921, teriam passado quase dez anos entre sua leitura e a utilização da expressão música popularesca, pois se presume que foi a partir 1931 que ele começou a usar o termo em seus escritos musicais ${ }^{182}$. Na documentação também se observou que, no início, popularesco foi um adjetivo usado de forma ocasional e, depois de 1938, começou a ser mais frequente, como se verá em seguida.

Nos primeiros anos da década de 1930, a palavra popularesco pode ser encontrada nas resenhas jornalísticas que Mário de Andrade escreveu acerca dos concertos de música erudita que assistiu em São Paulo. Nelas, o autor usou essa palavra para caracterizar ou descrever o que seus ouvidos escutaram, esforçando-se por levar os sons musicais às páginas do jornal. Nesse contexto, observou-se que o escritor empregou popularesco quando julgou que, na música interpretada, houve "algo" que provinha ou se usava também na música popular, o que deve tê-lo agradado, tendo em vista seu interesse pessoal em aproximar o popular e o erudito. Ao que parece, nessas resenhas, o adjetivo popularesco teve um uso descritivo e não depreciativo, ou seja, tudo indica que, ao parecer do escritor paulistano, uma peça denominada como tal não era de menor valor.

A título de exemplo, em 1931, ele qualificou como popularescos os elementos musicais herdados do romantismo por uma geração de compositores brasileiros, entre os quais, encontrava-se Henrique Oswald ${ }^{183}$. Dois anos depois, durante um recital da cantora Vera Janacopulos e outro do Quarteto Aguilar, chamou de popularescas duas obras do compositor espanhol-cubano Joaquin Nin $\mathrm{y}$ Castellanos, Da Murcia, que considerou “admirável de beleza linear e originalidade

182 Em um dos seus escritos, foi encontrado o emprego de popularesco no âmbito da literatura, quando qualificou a técnica dos escritores franceses Jules Laforgues, François Villon e Jean Rictus como "cheia de liberdades popularescas" (Andrade. "Laforgue e Satie." [1939] Música, doce música. Estudos da crítica e folclore, p. 299.). 168.

${ }^{183}$ Andrade. "Herinque Oswald." [1931] Música, doce música. Estudos da crítica e folclore, p. 
rítmica"184 e outra, cujo título não mencionou ${ }^{185}$. O mesmo termo foi usado para adjetivar uma das Novas sonatinas do francês Charles Koelichn, particularmente o “deliciosíssimo final, ronda popularesca que está entre as melhores coisas que Koechlin escreveu", tocada ao piano por Lavínia Viotti ${ }^{186}$. Também considerou como popularescos o allegro con brio de uma Sonata de Felice de Giardini, tocado por orquestra de cordas sob direção de Leon Kaniefsky ${ }^{187}$, e a interpretação feita pela pianista Guimar Novais de uma sonata de Scarlatti, no momento em que "chegou a sons dum napolitanado popularesco, de infinito sabor"188.

Quando Mário de Andrade usou o termo popularesco, suspeita-se que denominava elementos musicais mais sutis que os recursos usados no arranjo musical, o que sabia diferenciar muito bem. Na resenha do concerto da cantora Julieta Teles de Meneses, o escritor esclareceu que no programa havia "peças populares harmonizadas" hebraicas, francesas, espanholas, quéchuas e brasileiras, nas quais a cantora manteve um "equilíbrio delicioso entre o canto popular e a interpretação erudita, sem deformar coisíssima nenhuma", pois, como ele mesmo explicou, "é uma condição importantíssima, tratando-se de canções populares, porque a arte erudita, com os seus processos especiais de interpretação, é levada naturalmente a deformar os cantos populares e lhes prejudica por isso o recôndito perfume"189. Também, por ocasião de um dos concertos da Sociedade de Cultura Artística, Mário de Andrade esclareceu que as canções dos compositores Chaga Júnior e Mário Monteiro foram feitas sobre motivos populares portugueses e harmonizadas pelos músicos ${ }^{190}$. Nos dois exemplos, pode-se observar que Mário de Andrade não denominou essas harmonizações como obras popularescas, e parece ter reservado o adjetivo para outro tipo de música, talvez um tipo de música cuja raiz estivesse em um mundo intermediário entre o popular e o erudito.

184 Andrade, Mário de. "Quarteto Aguilar." [1933] In: Paulo Castagna (ed.), Música e Jornalismo: Diário de S. Paulo, São Paulo: Edusp/Hucitec., 1993, p. 27

185 Andrade. "Vera Janacopulos." [1933] Música e Jornalismo: Diário de S. Paulo, p. 59.

186 Andrade. "Lavínia Viotti." [1933] Música e Jornalismo: Diário de S. Paulo, p. 31.

187 Andrade. "Orquestra de cordas." [1933] Música e Jornalismo: Diário de S. Paulo, p. 55.

188 Andrade. "Guiomar Novais." [1933] Música e Jornalismo: Diário de S. Paulo, p. 60.

189 Andrade. "Cultura artística - Julieta Teles de Meneses." [1934] Música e Jornalismo: Diário de S. Paulo, p. 252.

${ }^{190}$ Andrade. "Cultura artística." [1934] Música e Jornalismo: Diário de S. Paulo, p. 137. 
Em 1941, em um de seus artigos a respeito das mudanças da modinha, Mário de Andrade voltou a usar o termo popularesco, talvez procurando criar um ponto médio entre a música folclórica e a música erudita. Acerca da existência de peças religiosas eruditas nas tradições camponesas, o musicólogo anotou que elas tinham sido "impostas ao povo pela classe eclesiástica — peças sabidamente de autor —, e que, como peças, quase nunca conseguem se popularizar folcloricamente. Tipo de fato popularesco, mas não exatamente popular"191. Assim, assinalou que algumas peças religiosas, embora impregnadas pelo caráter popular, não se transformaram em música folclórica, mas mantiveram seu estilo original e, consequentemente, acabaram pertencendo a um mundo intermediário entre o erudito e o popular.

Por outro lado, chamou a atenção o fato de que Mário de Andrade usasse, em um par de ocasiões, a palavra vulgar perto de popularesco, como se estivessem relacionadas, mas se suspeita que sua proximidade foi mediada por um significado particular que o autor atribuiu a vulgar. Em 1935, em uma resenha de um dos concertos do violinista Fritz Kreisler, ele esclareceu que o adjetivo popularesco não tinha um caráter vulgar. A palavra vulgar foi explicada por Andrade, no mesmo artigo, como "um não-sei-quê de asperidade de sentir, de esquecimento da cultura, quase de tosquidão. É uma grande ausência de malícia, essa castalia da arte"192. Essa elucidação foi feita para explicar a que se referiaquando dizia que a Chaconne de Bach, tocada naquela noite, era popularesca mas não era vulgar, vulgar no sentido dado por ele mesmo à palavra.

Parece até que, para o musicólogo, vulgar tinha um sentido em certo grau positivo, pois em um artigo em que se referiu à música de José Barbosa da Silva (Sinhô), quando passou por São Paulo em 1929, disse que o músico conservava dos cariocas:

aquele riso da experiência divertida, aquela leveza de borboleta, ingenuidade originalíssima, esperteza defensiva que só mesmo os índios, as crianças e... os cariocas possuem. E a sensualidade.

Quem for escutar Sinhô perceberá tudo isso nos poemas cantados que ele inventa. É possível que percebam também a banalidade na obra dele. Banalidade não. Vulgaridades, as quais serão banalidades apenas pros indivíduos que não sabem

${ }^{191}$ Andrade. "A modinha e Lalo." [1941] Música, doce música. Estudos da crítica e folclore, p. 343.

192 Andrade. "Kreisler." [1935] Música e Jornalismo: Diário de S. Paulo, p. 306. 
reaprender todos os dias, certos fenômenos, certas reações essenciais do «rei dos animais» diante do amor, da pândega e da sociedade ${ }^{193}$

No depoimento de Mário de Andrade a respeito de Sinhô tem-se a impressão de que ele entendia vulgaridade como um aspecto quase positivo e banalidade como algo nocivo. Dentre a correspondência do escritor, foi conservado um cartão enviado por Sinhô, no qual "Comprimenta e agradece o seu valioso auxilio em prol de sua festa a realizar-se em 19.5.1929 no Theatro Municipal”, de onde se deduz que Mário de Andrade mostrou certa simpatia pelo músico carioca ${ }^{194}$.

Dez anos mais tarde da visita do músico a São Paulo, Mário de Andrade voltou ao significado da palavra vulgar quando, no prefácio do livro Shostakovich, usou novamente o adjetivo. Nessa ocasião, advertiu que aplicava seu significado etimológico para chamar a música que era "fácil de apreensão e direta de efeito"195. Nesse escrito, qualificou a obra de Shostakovich de ter uma "vulgaridade popularesca"196, referindo-se às melodias feitas "à feição popular"197, que serviam para tornar sua música compreensível ao público proletário. Nesse escrito, Mário de Andrade deixou indicado que o contrário a vulgar era banal, e especificou dizendo que o sabor da água ou do arroz com feijão não era banal em comparação com um vinho da Borgonha ou um cuscuz paulista bem condimentado, e que o mesmo se passava com a música:

$\mathrm{Na}$ verdade, não se pode atribuir banalidade à música folclôrica, e só mesmo com muita reserva à música popularesca urbana, que serve para o gasto transitório da coletividade. Seria adotar um critério crítico individualista e hedonístico para um fenómeno do quotidiano utilitário. Mas de fato o produto folclôrico mesmo diante dum crítico estética, jamais é banal. A música folclórica é fácil, mas não banal. Pode ser vulgar, mas não banal ${ }^{198}$.

Embora o estudo dos conceitos vulgar e banal requeira uma análise do pensamento estético de Mário de Andrade, por ora se pode assinalar que, no fim da vida, o autor qualificou como "vulgares" a música popular urbana e folclórica,

193 Andrade. "Taxi: Sinhô." [1929] Taxi e Crônicas no Diário Nacional, p. 104.

194 Cartão de Sinhô para Mário de Andrade. São Paulo: Arquivo IEB - USP, Fundo Mário de Andrade - Correspondência passiva. MA-C-CPL6480, s.d.

195 Buscando a etimologia de vulgar à qual pode ter-se referido, consultou-se o exemplar do Dicionário etimológico da língua portuguesa (1932), de Antenor Nascente, da sua biblioteca, e se verificou que ali não existe uma entrada para essa palavra.

196 Andrade. "Shostacovich." [1945] Música Final. Mário de Andrade e sua coluna jornalística Mundo musical, p. 406.

197 Ibid., p. 400.

198 Ibid., p. 401. 
ressaltando-se que esse vulgar não tinha a carga depreciativa com que habitualmente se usava a palavra, mas sim um tom benéfico que despertava simpatia no autor, "um não-sei-quê de asperidade de sentir, de esquecimento da cultura, quase de tosquidão", como definiu em 1935.

Por outro lado, observou-se na documentação que, depois da passagem de Mário de Andrade pelo Departamento de Cultura, e já na década de 1940, o escritor começou a usar o adjetivo popularesco para qualificar certo repertório que circulava nos meios de comunicação eletrônicos, e não somente para algumas peças do repertório erudito, como tinha feito no começo da década de 1930. Em 1940, usou a expressão "discos popularescos" para caracterizar o repertório fonográfico que circulava pelas cidades ${ }^{199}$, e não os discos como tal, os quais, ao que parece, ele dividia entre científicos e comerciais, segundo as notas manuscritas citadas no início do capítulo.

Para se ter uma ideia do tipo de música que esses "discos popularescos" continham é interessante notar que, no ano seguinte, em uma menção muito rápida, Mário de Andrade qualificou com o termo popularesco a música das jazz-band "de nossos dias" ${ }^{200}$, gênero bem representado em sua coleção particular de discos. Quatro anos depois, em outro de seus escritos, o escritor usou como exemplos de música popularesca o samba $O$ que é que a Bahiana tem, cantado por Carmen Miranda, e a canção cubana $O$ vendedor de amendoim, os quais descreveu como "duas obra primas. Música popularesca, apenas urbana e semierudita, extra-folclórica, mas obras primas"201. As duas peças encontram-se gravadas em discos de sua coleção. O que é que a bahiana tem foi gravado pelo selo Odeon em $1939(\boldsymbol{\delta} \text { faixa } 25)^{202}$, e $O$ vendedor de amendoim está em duas versões, ambas da Discos Victor: uma com o título de The peanut vendor ( $\delta$ faixa 26$)^{203}$, à qual se referiu como versão "ianquep. 327.

199 Andrade. "Camargo Guarnieri." [1940] Música, doce música. Estudos da crítica e folclore,

200 Andrade. "A modinha e Lalo." [1941] Música, doce música. Estudos da crítica e folclore

201 Andrade. "Música universitária." [1944] Música final. Mário de Andrade e sua coluna jornalística Mundo musical, p. 161.

${ }^{202}$ O que é a bahiana tem. Samba interpretado por Carmen Miranda, discos Odeon $\mathrm{N}^{\circ} 11710$, de autoria de Dorival Caymmi, gravado em 1939.

203 The peanut vendor. Rumba fox-trot interpretado por Antonio Machin, Don Azpiazu e sua orquestra Casino Havana, discos Victor No22483, de autoria de Moises Simons, gravado em 1929. 
cubano"204, e a outra interpretada pelo Trio Matamoros ( $\boldsymbol{\delta}$ faixa 27$)^{205}$, em cuja capa deixou escrito: "Um acompanhamento instrumental bem brasileiro..." 206.

A única característica musical que Mário de Andrade atribuiu à música popularesca foi timidamente esboçada em seu artigo "Cândido Inácio da Silva e o lundu" (1945), quando parece dizer que a música folclórica sempre tinha texto, enquanto que a música popularesca podia não ter: "não trazem textos - caráter distintivo da manifestação que não é folclórica, mas apenas popularesca e urbana"207. Com essa particularidade, parece que queria incluir a categoria música instrumental a meio caminho entre o popular e o erudito, como é o caso do jazz.

Como se disse no segundo capítulo, nos últimos anos de vida, Mário de Andrade reduziu o uso da expressão música folclórica, e quando a usou foi para se referir pontualmente à música inculta e analfabeta, inconsciente e anônima ${ }^{208}$. Em contraposição a essa redução, durante esses mesmos anos, observou-se um uso mais frequente do termo música popularesca, singularmente aplicado à descrição da música que circulava nos discos e era difundida pela rádio. Embora a historiografia costume ver no termo uma forte conotação pejorativa, na leitura que se fez de seus escritos, observou-se que a palavra foi usada basicamente para dizer "[...] feito à feição do popular $[\ldots]^{209 "}$. Como se destacou, parece que o termo empregado pelo escritor paulistano para se referir a uma música desprezível foi submúsica, que era aquela que ganhava “o aplauso fácil". Embora em seus escritos o autor paulistano não tenha usado popularesco com um sentido desfavorável, parece que alguns de seus contemporâneos, ou até ele mesmo, em outros contextos, usaram popularesco como um adjetivo que tirava o valor da música popular, como ele deixou entrever uns dias antes de morrer.

${ }^{204}$ Arquivo do Instituto de Estudos Brasileiros. Catálogo Discos Mário de Andrade.

205 El manicero. Pregón-son interpretado por Trio Matamoros, discos Victor №46401, de autoria de Moises Simons, gravado em 1930 em Nova Iorque.

206 Ibid.

${ }^{207}$ Andrade. "Cândido Inácio da Silva e o lundu." [1945].

208 Andrade. "O desnivelamento da modinha." [1941] Música, doce música. Estudos da crítica e folclore, p. 344.

209 Andrade. "A música e a canção populares no Brasil. Ensaio crítico-bibliográfico." [1936] Ensaio sobre a música brasileira, p. 167. 
Em 1945, duas semanas antes de sua morte, saiu o último artigo de Mário de Andrade no periódico Folha da manhã, intitulado "Do meu diário", em que vinha publicando notas curtas sobre diversos temas. Nesse dia, o tema foi uma pequena reflexão acerca da natureza do popular e do popularesco, destacando uma contradição observada pelo autor. $\mathrm{O}$ artigo iniciou expondo que se acreditava que o popular estava ligado ao tradicional e o popularesco à moda. Mas Mário de Andrade notava que os fenômenos folclóricos (sinônimo de popular) não eram duradouros, podiam ser esquecidos em pouco tempo, mas seus elementos básicos ficavam repetidos na variação. Ao contrário, o popularesco implicava progresso, ou seja, transitoriedade, e passava rápido porque ia com a moda, mas não era raro que a moda voltasse e um tema musical popularesco fosse ouvido novamente e exatamente igual, porque, se mudasse, correria o risco de não ser reconhecido.

Nesse artigo, Mário do Andrade afirmava que o folclórico não precisava de um museu por sua natureza antimuseológica, e que o popularesco, que não era considerado digno de museu, tinha uma natureza imutável, ou seja, museológica: “Quem toca um tango de Nazaré, lhe modificando parte da melodia está errado. Quem executar o Tutu Marambá, na variante de sua região, não está errado"210.

Nesse último escrito, Mário de Andrade partiu de uma espécie de acordo tácito a respeito da consideração do popularesco enquanto relacionado à moda $\mathrm{e}$ possuidor de escasso valor. Se o autor tinha dado a entender que popularesco era algo "feito à feição do popular", então, quem atribuía essas características depreciativas ao termo? Incomodava-se Mário de Andrade com essa "tergiversação"? Se era isso, o que ocorreu? Uma resposta responsável implicaria uma revisão detalhada das interpretações que seus colegas construíram sobre seus escritos e um estudo mais detalhado sobre sua relação com o musicólogo paulistano. Por ora, considera-se que essa tensão entre o termo popularesco como "feito à maneira popular", aparentemente neutro, e sua conotação depreciativa, é sintomática do conflito que se forjava entre a visão romântica do popular e a comercialização em voga da música popular urbana. Ao mesmo tempo, remete às mudanças no universo

\footnotetext{
${ }^{210}$ Andrade. "Do meu diário." [1945] Música final. Mário de Andrade e sua coluna jornalística Mundo musical, p. 179.
} 
musical de meados do século XX, que começaram a penetrar no conceito de música popular.

Na comparação entre o Compêndio da história da música, publicado em 1929, e a Pequena história da música, publicada em 1942, chamou a atenção o fato de que, no capítulo a respeito da música brasileira, Andrade adicionou, na segunda edição, o termo popularesca para qualificar a poesia cantada por Catulo da Paixão Cearense $^{211}$. A partir dessa mudança, deduz-se que, em 1929, Mário de Andrade considerava que a música difundida pela indústria fonográfica era simplesmente música popular, mas que, 13 anos depois, percebeu que estava diante de um músico que, na realidade, fazia um novo tipo de música que não era exatamente igual àquela que, em 1929, tinha chamado de popular. No fundo, teria percebido que era somente uma música "feita à feição popular".

Pode-se pensar que a mudança no ambiente musical, ocasionada pela radiodifusão e pela indústria discográfica, já mencionadas, fez com que Mário de Andrade incrementasse o uso da expressão música popularesca para denominar essa nova música. Como afirmou Alberto Cavalcanti, Andrade fez a distinção entre o popular e o popularesco quando:

Mário já dispunha de fenômeno consolidado de exploração da música de feitio popular - seja no rádio, seja no disco, ou ainda em novos espaços, como os filmes musicais e os cassinos - e já podia observar o modus operandi dos autores e intérpretes envolvidos na composição e execução musical afastando-se dos procedimentos mais espontâneos e ingênuos - ou mais tradicionais e oitocentistas - do período anterior ${ }^{212}$.

Conforme foi enunciado, as mudanças que a radiodifusão e a empresa discográfica trouxeram, refletiram-se na configuração paulatina de um repertório com particularidades musicais próprias. Começou a surgir uma sonoridade nova na música gravada, que inicialmente estava relacionada com as características técnicas do processo de gravação, e que se terminaram por se fixar como características da própria música. De acordo com Virgínia de Almeida Bessa, o processo de gravação, por exemplo, influiu na instrumentação escolhida para ser gravada pois:

as sonoridades típicas do jazz [...] podiam ser registradas e reproduzidas em disco com grande «fidelidade» (ou seja, mantendo muitas das características sonoras que se escutava na performance ao vivo). O mesmo não ocorria com a música de

211 Andrade. Pequena história da música. [1942] p. 193.

212 Cavalcanti. Música popular: janela-espelho entre o Brasil e o mundo. p. 66. 
concerto nem com os gêneros de música ligeira executados pelas orquestras tradicionais, cujos timbres não eram captados com precisão [...] os principais instrumentos a participarem das primeiras gravações elétricas, a partir de 1927, seriam justamente o pistom, o trombone, o saxofone, o piano, o banjo, o violão e a bateria [...]. Os violinos também receberiam algum destaque, sobretudo nas gravações de músicas lentas. Mas o fagote, o oboé, a trompa, a viola, o violoncelo e outros instrumentos sinfônicos foram condenados ao esquecimento ${ }^{213}$.

Também Orestes Barbosa, em 1933, reconheceu que a técnica dos cantores variou na hora de gravar, e contou o caso de um barítono que, por cantar empostado, seguindo a técnica do canto lírico, chegou de volta ao Rio de Janeiro e não pôde competir com os novos cantores habituados ao microfone "porque hoje cantando não se berra mais"214. O mesmo Mário de Andrade, em "Terapêutica musical” (1939), diferenciou a velocidade do ritmo na música folclórica e na música gravada:

a música popular brasileira raríssimamente, a bem dizer nunca, atinge os andamentos rápidos que vão do «presto» ao «prestíssimo». O presto de algumas emboladas e modinhas urbanas que escutamos em discos, é criação artificial, provocada pela influência da música erudita ou semi-erudita, importada da Europa e dos Estados Unidos ${ }^{215}$.

Não por acaso, Mário de Andrade afirmou, em 1931, que "são as grandes casas de fonografia que se incumbem atualmente da fixação e evolução da nossa dança cantada"216. Efetivamente, já desde 1927, o catálogo da Victor Talking Machine orgulhava-se de apresentar Nathaniel Shilkret, seu gerente e diretor musical, que, segundo a propaganda do catálogo, gozava do seguinte reconhecimento:

Actualmente no hay otro hombre que haya hecho tanto por la música popular en el Nuevo Mundo como Nathaniel Shilkret. Él ha invertido el proceso muy común de tomar material de los grandes clásicos de la música y remodelarlo para el consumo popular. En vez de esto, Shilkret ha tomado la efímera música popular, y refundíola en los perennes moldes del divino arte de la música ${ }^{217}$.

Certamente, a música que circulava nos discos começava a ter uma fisionomia própria e, portanto, acredita-se que o uso de popularesca é um indício de que o conceito de música popular começava a oscilar e procurava libertar-se da visão de mundo romântica para criar um novo matiz, por meio do novo termo, que incluía o fenômeno midiático dentro da taxonomia habitual.

${ }^{213}$ Bessa. «Um bocadinho de cada coisa»: trajetória e obra de Pixinguinha. História e música popular no Brasil dos anos 20 e 30. p. 138.

214 Barbosa. Samba: sua história, seus poetas, seus músicos e seus cantores. [1933] p. 68.

215 Andrade. "Terapêutica musical." [1939] Namoros com a medicina, p. 17.

216 Andrade. "Carnaval tá aí." [1931] Taxi e Crônicas no Diário Nacional, p. 321.

${ }^{217}$ Catálogo de discos Victor: 1927 con material biográfico, anotaciones sobre óperas, fotografias de artistas y otras.... New Jersey: Victor Talking Machine, 1927, p. 7. 
Por outro lado, deixa-se para futuras pesquisas a especulação a respeito da carga pejorativa atribuída ao conceito música popularesca seja uma construção historiográfica e não uma particularidade do pensamento musical de Mário de Andrade, pois, à luz das leituras feitas, observou-se que seu uso não se restringiu a qualificar a música popular urbana, mas também algumas peças de procedência erudita, todas apreciadas por ele. Possivelmente o desdém com que alguns contemporâneos contemplaram a música midiatizada seja o primeiro responsável pela distância que se encontrou entre os escritos de Mário de Andrade e o uso do termo na historiografia musical brasileira. Não obstante, o escritor modernista expressou um forte desprezo por um tipo de música que denominou como submúsica, aquela que considerou como sendo de ínfimo valor por apelar para recursos fáceis a fim de ganhar a aceitação rápida do público, e que encontrou tanto nos teatros e em seus músicos virtuosos quanto na rádio e nos discos.

\section{A influência estrangeira}

Como se viu, um dos elementos que desgostaram a quem, em certa medida, não foi cativado pela música comercializada em discos, foi sua proximidade com a música popular do exterior, particularmente com a estadunidense, cujo impacto na América Latina foi importante e terminou por influenciar marcadamente o gosto musical, principalmente o hispano-americano.

Um dos principais motivos pelos quais se considera que Mário de Andrade tenha rechaçado a música difundida pela rádio e pelos discos é que, precisamente, tratava-se de uma música com fortes influências estrangeiras, contrária ao ideal de música nacional atribuído ao autor. Entretanto, voltando a seus escritos, parece que essas influências nem sempre foram sancionadas negativamente, e se percebe que, durante a década de 1920, sua mente estava aberta aos intercâmbios musicais, pois entendia que eles faziam parte da mesma natureza de música. Por exemplo, em 1926, analisando as influências musicais na obra de Ernesto Nazareth, ele encontrou rastros de melodias europeias e disse:

É evidente que não tenho tempo a perder pra estar bancando o purista e o patriótico. Acho mesmo um encanto humano em perceber elementos estranhos numa qualquer jóia da invenção popular, seja numa farça do Piolin como Do Brasil ao Far-West, seja no maxixe recente Cristo nasceu na Baia, onde se intromete a 
horas tantas um meneio melódico norte-americano. Minha opinião é que o destino do homem fecundo não é defender os tesouros da raça, mas aumentá-los porém ${ }^{218}$.

Em 1928, Mário de Andrade disse aos compositores que os processos do jazz estavam influenciando o maxixe sem prejudicá-lo, enquanto que as melodias do tango eram muito chorosas e deveriam ser filtradas. Nesse momento, parece que ele tinha uma opinião ligeiramente diferente acerca das influências estrangeiras naturais na música popular brasileira, e convidou os compositores a:

[...] selecionar a documentação que vai the servir de estudo ou de base. Mas por outro lado não deve cair num exclusivismo reacionário que é pelo menos inútil. A reação contra o que é estrangeiro deve ser feita espertalhonamente pela deformação e adaptação dele. Não pela repulsa ${ }^{219}$.

Possivelmente, essa seleção dos elementos musicais estrangeiros a serem incorporados na música devia passar por um exercício consciente do compositor que, em seu trabalho de artesão, deveria reconhecer a medida que eles teriam em sua criação musical. Parece que esse conselho baseava-se na observação de que, na realidade, as influências internacionais eram naturais e faziam parte da mesma história dos desenvolvimentos musicais em diferentes países.

Um exemplo claro do movimento dessas influências foi dado por Andrade mesmo em seu curto artigo "Cuba, outra vez" (1932), em que identificou a grande influência que a música afro-cubana exerceu na configuração da habanera e, por meio dela, no tango e no maxixe, para mais tarde retornar ao Brasil pelas mãos da música norte-americana.

[...] agora, volta de novo, é verdade que via Estados Unidos, [...] Pois os americanos descobriram certos efeitos curiosos e músicas bonitas afrocubanos e criaram o «rumba fox» que, a meu ver, vale principalmente pelos novos efeitos com que enriquece a orquestra do «jazz». Está claro que os brasileiros logo fizeram rumbas e até os efeitos sinfônicos do nosso gostoso choro estão se modificando com a introdução de instrumentos novos. [...] não faz mal não. Como da primeira feita, a influência vai sendo utilíssima, produzindo peças admiráveis ${ }^{220}$.

Segundo o comentário que fez em uma das capas de seus discos, parece que o caso dos trânsitos musicais entre Cuba e Brasil era uma pergunta sem resposta fácil. Depois de ouvir os sambas Tava na roda do samba $(\boldsymbol{\delta} \text { faixa } 28)^{221}$ e Deixa a

\footnotetext{
126.

${ }^{218}$ Andrade. "Ernesto Nazaré." [1926] Música, doce música. Estudos da crítica e folclore, p.

219 Andrade. Ensaio sobre a música brasileira. [1928] p. 26.

${ }^{220}$ Andrade. "Cuba, outra vez." [1932] Taxi e Crônicas no Diário Nacional, p. 488.

221 Tava na roda do samba. Samba interpretado por Almirante e o Bando de Tangerás, discos Victor No 33524, de autoria de Salvador Correira, gravado em 1932.
} 
Nêga Pená ( $\delta$ faixa 29)222, interpretados por Almirante e o Bando de Tangarás, escreveu: "As duas faces trazem o ritmo ternário tomando todo um compasso doispor-quatro. Isso recentemente apareceu na rítmica do samba carioca. Virá de influência cubana, onde é sistemático?...”223.

Parece que a influência da música forânea, aceita por Mário de Andrade, quando tinha 33 anos, referia-se à mescla e fusão de elementos musicais, mas não à difusão de música estrangeira de baixa qualidade. Como se viu, uns anos depois, ele denunciará com veemência que a produção discográfica era plagiadora e falsa "como as canções americanas de cinema, os tangos argentinos ou fadinhos portugas de importação"224, dando, à primeira vista, a impressão de rejeitar totalmente as influências estrangeiras. Já com 46 anos de idade, Mário de Andrade opinava que o perigo de que a música de outros países continuasse sendo difundida na rádio e nos discos residia no fato de que "a música urbana, mesmo de gente do morro, é eminentemente instável e se transforma fácil, como as coisas que não têm assento numa tradição necessária"225.

Em resumo, as posturas em relação à música estrangeira são matizadas. Em sua juventude, Mário de Andrade aceitava o contato entre a música brasileira e a do exterior, que chegava via discos e rádio, e considerava que esse intercâmbio enriqueceria os gêneros musicais brasileiros, sempre que os músicos tivessem um critério estético nacional formado. Depois, com o passar dos anos, tornou-se desconfiado diante da influência que essa música estava tendo e adotou uma postura mais conservadora, pois talvez considerasse que nem sempre essas fusões proporcionavam produtos de utilidade social, mas simplesmente comercial, e terminavam beneficiando a poucos. Por outro lado, durante o último período de sua vida, parece que nosso autor rechaçou a suplantação da música brasileira pela música estrangeira porque considerava que era o critério comercial o que estava por trás disso, um critério que, em poucas palavras, procurava "o aplauso fácil”, estando

\footnotetext{
${ }^{222}$ Deixa a Nêga Pená. Samba interpretado por Almirante e o Bando de Tangerás, discos Victor №33524, de autoria de Paulo Cardoso, gravado em 1932.

${ }^{223}$ Arquivo do Instituto de Estudos Brasileiros. Catálogo Discos Mário de Andrade.

${ }^{224}$ Andrade. "Música popular." [1939] Música, doce música. Estudos da crítica e folclore, p. 281.

${ }^{225}$ Ibid., pp. 281-282.
} 
muito distante do papel social comprometido que Mário de Andrade reclamava à música anos antes de morrer.

Por outro lado, é importante matizar essa rejeição da música do exterior com que a historiografia caracterizou os intelectuais da época de Mário de Andrade, pois nem todos os escritores pensaram que sua influência era prejudicial. Sobretudo nas primeiras décadas do século XX, observam-se algumas mostras de tolerância para com a música popular de outros países e para com sua difusão em terras latinoamericanas. Um exemplo dessa posição foi a opinião da Mariza Lira, quem pensava que era normal a criação de uma música que satisfizesse as necessidades da época: "Nos cancioneiros modernos há o desejo de criar uma nova forma sentimental que satisfaça às exigências do momento, influenciados talvez pelas músicas estrangeiras" ${ }^{\prime 226}$.

No seu entender era o que tinha acontecido com a modinha que, nem por isso, tinha deixado de ser brasileira. Afinal, a identidade nacional mantida era o que realmente importava dado o sentimento nacionalista imperante do momento:

A canção nada mais é que a estilisação da modinha $[\ldots]^{227}$.

A modinha sofreu um pouco com a vitória das músicas estrangeiras, mas, foi um ligeiro colapso para ascender mais moderna $[\ldots]^{228}$.

A modinha não poude deixar de seguir a corrente progressista. Hoje a encontramos modernizada, mas, sempre ternamente brasileira ${ }^{229}$.

Curiosamente, a respeito da transformação da modinha em canção, há uma nota manuscrita de Mário de Andrade sobre a capa do disco Victor No33951. Esse disco contém as interpretações do Grupo de Canhoto e Floriano Belham dos sambacanções Morena que dorme na rede $(\boldsymbol{\delta} \text { faixa } 30)^{230}$ e Saudades de meu barracão $(\delta$ faixa 31 ${ }^{231}$. Sobre sua capa, Mário do Andrade escreveu:

"Modinha" - À medida que esta desaparece ou vive mais desatendida dos seresteiros, vai sendo porém substituída pelo samba-canção, que é realmente uma modinha nova, de caráter novo, mas canção lírica solista, apenas com uma rítmica

\footnotetext{
${ }^{226}$ Lira. Brasil sonoro. Generos e compositores populares. p. 191.

227 Ibid.

228 Ibid., p. 43.

229 Ibid., p. 47.

${ }^{230}$ Morena que dorme na rede. Samba-canção interpretado por Floriano Belham e Grupo do Canhoto, discos Victor No 33951, de autoria de Roberto Martins e Wilfrido Silva, gravado em 1935.

231 Saudades de meu barração. Samba-canção interpretado por Floriano Belham e Grupo do Canhoto, discos Victor No33951, de autoria de Ataulfo Alves, gravado em 1935.
} 
fixa de samba, em que porem a agógica já não é mais realmente coreográfica, mas de canção lírica. Ora isso é uma evolução lógica, por assim dizer, fatal. A modinhade-salão passada pra boca do povo popular adotou mesmo ritmos coreográficos, o da valsa e o da chótis principalmente. Ora estes eram sempre ritmos importados, não da criação imediata nacional. O samba-canção é a nacionalização definitiva da modinha ${ }^{232}$.

Como se pode ver, existia um certo consenso entre Mário de Andrade e Mariza Lira de que a influência estrangeira tinha modificado a modinha, de modo que ela guardava uma íntima relação com a canção que se ouvia nos discos. Não obstante, Mariza Lira notou que essa mesma canção brasileira continuava sendo transformada por influências da música estrangeira, e Mário do Andrade parece ter celebrado secretamente, na intimidade de sua casa, a nacionalização da modinha em seu formato de samba-canção.

Por outro lado, a Mariza Lira tampouco passou desapercebida a influência que o tango e o jazz exerciam sobre a música brasileira, particularmente sobre o samba. Seu argumento ratificou a ideia, mencionada por Mário de Andrade, de que a música popular brasileira era mutável, e, sob uma perspectiva evolucionista, estaria em etapa de formação.

Influenciados pelas vistas ao Prata alargaram-lhe o ritmo e já temos o sambatango.

O jazz americano tem tido sôbre o samba influência sensível, mas, o mais inverosímil, e que já se tentou impor-nos o samba-fox.

Isso nos prova que a nossa música popular atravessa uma fase incerta, em longe da fixação ${ }^{233}$.

Parece que Mariza Lira escreveu acerca da influência da música estrangeira no Brasil sem frases condenatórias porque, a seu ver, essa realidade não punha em perigo a natureza da música popular brasileira, tampouco competia com sua beleza. Lira comparou a música popular de seu país com a música norte-americana que chegava por meio do cinema, concluindo que não eram menos lindas as composições dos compositores brasileiros. Portanto, pôde pensar que aquela música não representava um perigo para a música do Brasil2 ${ }^{234}$. Também fez curtas menções a outros gêneros estrangeiros que estavam tendo aceitação no Brasil, como é o caso da

232 Arquivo do Instituto de Estudos Brasileiros. Catálogo Discos Mário de Andrade.

${ }^{233}$ Lira. Brasil sonoro. Generos e compositores populares. p. 262.

234 Ibid., p. 225. 
ranchera, do pericón, do cak-walk, do rag-time, do charleston, do fox-trot, da habanera e da rumba,

A ranchera de origem hispano-americana é muito usada no Rio Grande do Sul.

O pericón é dansa regional gaucha. A música que acompanha essa dansa figurada, reflete o ritmo platino.

O cak-walk, as várias modalidades do rag-time e as suas derivantes modernas, do charleston ao fox-trot, nos vieram do negro norte-americano.

Entre as nossas músicas populares figuraram muitos foxes com música e letras brasileiras.

A habanera e a rumba nos chegaram da América Central. A rumba começa a se divulgar entre nós com músicas de nossos compositores ${ }^{235}$.

Fora do Brasil, houve outros escritores que também deram amostras de compreender como não prejudicial a influência de ritmos estrangeiros na música de seus países. Em 1922, quando o cubano Eduardo Sanchez de Fuentes analisava para seus leitores as características da canção cubana, não condenou o fato de que nesse gênero houvesse semelhanças com a canção mexicana, mas, ao contrário, esclareceu que elas eram completamente naturais, dada a proximidade cultural que existia entre os dois países:

Esta forma [repetición de la parte A al terminar la canción] se observa en las canciones mexicanas y dado el nexo que nos une con dicha República por la cercana vecindad y analogía en algunos de los ritmos que en ambos países se cultivan, no es de extrañar que lo haya adoptado nuestra canción, máxime cuando es ésta una tendencia de origen español y que encaja perfectamente dentro del género $^{236}$.

Seu colega mexicano Rubén M. Campos, em 1928, ao enumerar os gêneros que formavam o folclore mexicano, também mencionou ritmos estrangeiros como a dança cubana, e outros europeus como a mazurca, a polca e o $\operatorname{schottisch}^{237}$. Não obstante, advogou pela especificidade nacional desses gêneros e explicou que, "nuestras formas musicales populares, recuerdan los aires españoles pero son diferentes..."238, argumento com o qual, tornou explícita a importância que o nacionalismo tinha em sua obra.

Em geral, o nacionalismo musical latino-americano da primeira metade do século XX, caracterizou-se pela convergência do interesse por uma arte nacional,

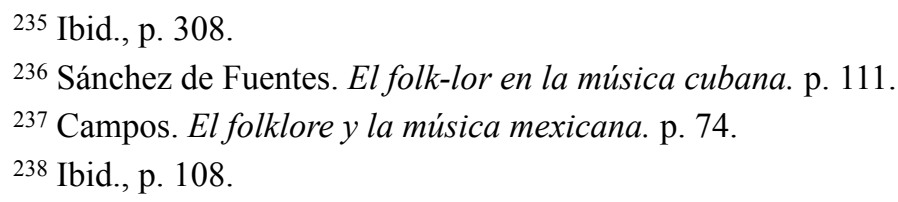


fundamentada no folclore, e pela arte universal, baseada na tradição musical europeia $^{239}$. Como é sabido, o nacionalismo musical esperava que o compositor não fizesse imitações exóticas de sua música nativa, mas sim reelaborações da música popular de seu país na linguagem musical erudita. É possível que essa mesma ambiguidade entre o nacional e o internacional tenha permeado a relação com a música popular estrangeira. Talvez se tenha tolerado a utilização de certos elementos próprios de outros países, desde que estes não tirassem o caráter nacional da música popular. Dessa forma, a música popular modernizar-se-ia e entraria no concerto internacional. Os escritores latino-americanos reprovavam aquela música popular elaborada com clara influência estrangeira, que dava a impressão de ter degringolado com os temas populares conhecidos e de fazer o que faziam os "compositores exóticos”, segundo a opinião do mexicano Miguel Galindo.

[...] y producen una música que, guardadas las debidas distancias, es comparable al lenguaje que usan los mejicanos pedantes que, después de unos años en Estados Unidos, pretenden hacer creer que que han olvidado el castellano y lo hablan con pronunciación incorrecta, fingida, chocante, ridículamente gutural [...]. Tal sucede a la música, y apenas si se nota que se pretendió escribir algo nacional por la interpolación de melodías populares muy conocidas ${ }^{240}$.

Além disso, Miguel Galindo achava que a chegada da música estrangeira ao país por meio de discos de acetato punha em desvantagem a música mexicana, já que:

se ve que nuestra producción artística musical no es ni la mitad de lo que pudiera ser, porque las obras nacionales, no son ni buscadas ni apreciadas; la música extranjera, servida en el negro platillo del disco, ha indigestado las almas y las ha desviado de su sentimentalidad propia ${ }^{241}$.

Por outro lado, observou-se que os autores que fizeram as denúncias mais precoces a respeito do prejuízo causado pela circulação de música estrangeira em seu país, foram dois cronistas brasileiros que, sem experiência prévia em pesquisa musical, mostraram posições cautelosas. Para Orestes Barbosa, em 1933, era preciso criar orquestras típicas de samba, diferentes das de tango e fox-trot e, assim, convidava seus leitores a admirar a "América do Norte" porque, lá, a música dos outros era criada, e não imitada ${ }^{242}$. Alexandre Gonçalves Pinto (Animal), que

\footnotetext{
${ }^{239}$ Contier. Brasil Novo. Música, nação e modernidade: os anos 20 e 30. p. 26.

${ }^{240}$ Galindo. Nociones de la historia de la música mejicana. p. 610.

${ }^{241}$ Ibid., p. 33.

${ }^{242}$ Barbosa. Samba: sua história, seus poetas, seus músicos e seus cantores. [1933] p. 69.
} 
claramente se orgulhava da música popular urbana do Rio de Janeiro, queixou-se, em 1936, de que "Hoje só imperam as músicas estrangeiras barulhentas e irritantes"243 e foram deixadas de lado as obras de músicos tão importantes - na opinião do autor — como Catulo da Paixão Cearense.

À medida em que o século XX foi transcorrendo e os gêneros mexicanos, cubanos, argentinos e norte-americanos entraram ao Brasil e se assentaram em solo latino-americano, fizeram-se mais frequentes as opiniões contrárias à influência dos gêneros estrangeiros. Por exemplo, Emirto de Lima foi enfático em sua prevenção: “A diario vemos como nuestra gente prefiere y aplauden una gran cantidad de músicas que nos llegan del extranjero, que nada dicen a nuestro sentir y que en el fondo son asaz vulgares y antiestéticas" ${ }^{244}$.

Em 1942, organizou-se, em Barranquilha, um concurso de música do qual Emirto de Lima participou como jurado. Em um artigo curto, o compositor contou que a terceira colocação foi conferida a um jovenzinho que cantou uma canção mexicana tão bem que teria merecido o primeiro lugar, mas esclareceu que não lhe outorgou essa colocação por não ter cantado uma obra colombiana. "Parece que las bases del concurso no fueron suficientemente conocidas por parte del público: de alli que todos los cantores aislados se presentaron con números mexicanos, cubanos $y$ argentinos"245. A apropriação de um gênero estrangeiro em Porto Rico foi considerada a partir de uma perspectiva diferente: Fernando Callejo Ferrer, em 1910, não reclamou de um dos primeiros reconhecimentos recebidos pela pianista Moncerrate Ferrer Otero como compositora ter sido o seu two-step intitulado Apolo $^{246}$. Assim, vê-se como, com o passar dos anos, a posição diante da entrada e influência da música popular estrangeira em cada país mudou porque se chocou com os ideais nacionalistas. Com isso, no transcorrer do século XX, os escritores musicais acusaram cada vez mais sua presença.

\section{Processos de folclorização e popularização}

243 Pinto, Alexandre Gonçalves (Animal). O Choro, Reminiscências dos chorões antigos. [1936] Rio de Janeiro: MPB reedições Funarte, 1978, p. 74.

${ }^{244}$ Lima. Folklore colombiano. p. 169.

245 Ibid., p. 200.

${ }^{246}$ Callejo Ferrer. Música y músicos portorriqueños. p. 227. 
As menções de Mário do Andrade à folclorização e popularização da música fizeram-se mais frequentes nos escritos da década de 1940, como se a angústia e a crise pessoal que vieram depois do seu ativismo no Departamento de Cultura, o tivessem levado a retomar um tema teórico que o ajudasse a compreender as realidades sociais e políticas, realidades que, sentia, o estavam ultrapassando. Com esse tema, encerra-se o presente capítulo, em consonância com o tom de seus últimos escritos, mas sem ser conclusivo quanto ao seu pensamento musical, nem em relação a uma definição de música popular, a qual continuou em construção.

Ao longo de sua vida, Mário do Andrade interessou-se pelos processos, técnicas e procedimentos de criação artística na literatura, música, pintura e escultura, talvez motivado por suas próprias preocupações de professor, crítico e artista. Dentro da questão da criação artística, dois aspectos que se relacionavam com seu conceito de música popular eram o da criação coletiva e o dos processos de folclorização e popularização no meio musical. Embora não tenha dedicado uma publicação específica ao tema, deixou menções que complexificam seu conceito de música popular.

Parece que nosso autor diferenciava a folclorização de um material musical em dois sentidos: por um lado, no sentido de constituição de uma tradição; por outro lado, em um sentido de aceitação de uma obra musical por parte do grande público. Em 1943, Mário de Andrade afirmou, acerca da música de Scarlatti e Chopin, que seu "folclorismo" era pura imaginação e que, na realidade, Scarlatti era popular no sentido de que foi aceito pelo povo, e não por incluir elementos musicais tradicionais. Além disso, admitia que essa aceitação devia-se ao fato de que ele "deu ao seu cravo a capacidade máxima, a intrinsecação perfeita e a técnica

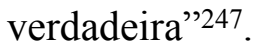

Um dos primeiros indícios de seu interesse pela criação coletiva está no artigo "Dinamogenias políticas", em que tentou estudar a música que foi cantada em São Paulo pela multidão à chegada de Getúlio Vargas e João Pessoa Cavalcanti, em 1930. Transcreveu seis letras e ritmos cantados naquela ocasião e tentou encontrar uma forma lógica de explicar a maneira como a assistência do desfile escolheu cantar

247 Andrade. "Scarlatti." [1943] Música final. Mário de Andrade e sua coluna jornalística Mundo musical, p. 73. 
determinados hinos, ou seja, suas "escolhas" musicais espontâneas e, assim, explicar a psicologia musical de um povo que era motivado pelas dinamogenias musicais ${ }^{248}$.

Como se mencionou, em seu artigo "O samba rural paulista” (1937), Mário de Andrade também mostrou interesse nos momentos culminantes de criação do samba, aos quais chamou "consulta coletiva",

Me sinto em enorme hesitação no definir e descreve exatamente esse interessantíssimo momento preludiante do samba que intitulei de «consulta coletiva». Ser de-fato um momento em que todos se consertam para adotar um novo texto-melodia, me parece realmente a finalidade mais definida dessa maneira de agir ${ }^{249}$.

Como se mencionou no segundo capítulo, Mário de Andrade foi incrédulo quanto à ideia de que a criação coletiva desse-se segundo os termos do folclore e considerou que, por trás de toda obra popular, havia sempre um indivíduo criador. Ao final de sua vida, e após fazer maiores elaborações a respeito da maneira como algo podia chegar a ser popular, em seu artigo "A modinha e Lalo" (1941), parece propor que os processos de folclorização autênticos davam-se pela "fatalidade e inconsciência com que cria" o cantor popular, e somente depois é que viria um processo de coletivização ${ }^{250}$. Em termos mais obscuros, e segundo seus diálogos de O banquete (1943), parece que Mário de Andrade chegou a considerar que a criação popular tinha uma técnica artesanal que não emanava dos homens, mas sim do objeto ou matéria-prima. Parece que, para ele, um dos aspectos da técnica, particularmente nas criações populares, era imposto pelo material que se trabalhava. Ora, o fato de que o material impunha aspectos técnicos implica que essa técnica não era exclusivamente popular.

Existe uma técnica popular, uma técnica de espírito folclórico, fatalmente tradicional, artesanal por princípio. É o artesanato. Mas esta técnica, nascida do material e da obra-de-arte, não é exclusivamente popular, pois não deriva do homem mas do objeto ${ }^{251}$.

Por outro lado, se o indivíduo criava por "fatalidade e inconsciência", essa nova criação devia ter algo que facilitasse sua coletivização. É provável que, ao final de sua vida, o musicólogo brasileiro estivesse perto de propor alguns elementos

248 Andrade. "Dinamogenias políticas." [1930] Música, doce música. Estudos da crítica e folclore.

249 Andrade. "O samba rural paulista." [1937] Aspectos da música brasileira, p. 120.

${ }^{250}$ Andrade. "A modinha e Lalo." [1941] Música, doce música. Estudos da crítica e folclore, p. 341.

${ }^{251}$ Andrade. O banquete. [1943] p. 66. 
musicais que faziam com que uma composição gozasse da aceitação do público e se popularizasse.

No prefácio do livro Shostakovich, Andrade mostrou-se interessado por estudar a música do compositor russo em busca das particularidades que facilitavam sua aceitação por parte das massas, já que esse era o propósito com que tinha sido composta tal música. Ao que parece, Andrade encontrou nela os mesmos elementos que caracterizavam a música dos séculos XVIII e XIX, como é o caso do uso da tonalidade e de formas musicais que, segundo o musicólogo, vinham-se tradicionalizando ou se folclorizando graças à "música mecânica"252. Além disso, Andrade identificou que as melodias popularescas e o virtuosismo empregado por Shostakovich eram dois elementos que costumavam despertar o entusiasmo do público coletivo e popular.

A "tradicionalização" ou "folclorização" de elementos musicais eruditos, a causa de sua difusão pelos discos e a rádio, parece indicar que, durante seus últimos anos, Mário de Andrade percebia que, musicalmente, as tradições erudita e popular, que o rodeavam, eram mais similares do que a terminologia deixava ver. Essa semelhanças eram a causa básica que, por exemplo, fazia com que uma melodia erudita fosse adotada pelo povo, pois, na realidade, sua forma e estrutura não eram desconhecidas, uma vez que a matéria prima era a mesma ${ }^{253}$.

Paradoxalmente, tem-se a impressão de que o estudo dos processos de folclorização e popularização estavam enfrentando Mário de Andrade com perguntas-chaves que preocupavam também a empresa discográfica; esta, pelo seu interesse em garantir um mercado para seus produtos. Mas, por outro lado, parece que, por meio dessas mesmas inquietações, o musicólogo brasileiro aproximava-se das complexidades teóricas que o ambiente musical criava e, talvez, de uma futura necessidade de repensar seu conceito de música popular.

\footnotetext{
252 Andrade. "Shostacovich." [1945] Música Final. Mário de Andrade e sua coluna jornalística Mundo musical, p. 399.

253 Andrade. "O desnivelamento da modinha." [1941] Música, doce música. Estudos da crítica e folclore, p. 348.
} 


\section{CONSIDERAÇÕES FINAIS}

O estudo da história da construção do conceito música popular, por intermédio do pensamento de Mário de Andrade, corroborou com a ideia de que esse foi um conceito com funções taxonômicas no pensamento musical da primeira metade do século XX. O estudo dessa história também ilustrou o uso ambíguo que teve o conceito nos discursos da época, devido à polissemia que o caracterizou.

É importante levar em conta que a história do conceito música popular, aqui esboçada, faz parte de um problema teórico que vai além do campo musical. O assunto da definição do vocábulo encontra-se relacionado com a delimitação temática de um campo de estudo e com a nomeada "invenção do popular" nas ciências sociais, da qual vem dando conta a historiografia da cultura popular, durante a segunda metade do século XX. Ao que tudo indica, as características e as mudanças que teve o conceito de música popular, especificamente na obra musicológica de Mário de Andrade, podem ser consideradas como indicadores das complexidades de um processo geral de definição teórica do popular, neste caso, durante a primeira metade do século XX e no contexto musical latino-americano.

Procurar compreender a configuração da polissemia da categoria música popular levou-nos ao final do século XIX, para observar a introdução do termo no vocabulário musical latino-americano. A partir de uma documentação parcial, expôsse a possibilidade de que, por volta do fim do século XIX, o conceito música popular não existisse em nosso contexto como categoria mental relevante. Observou-se que, até essa data, nos escritos musicais, seus autores costumavam classificar a música, principalmente, como música sacra e música profana, e não se encontraram rastros do uso de música popular como epíteto notável.

Ao que parece, o surgimento posterior da categoria música popular esteve relacionado com a influência do pensamento romântico na América Latina. Esse pensamento romântico foi entendido, no presente estudo, como crítica aos processos 
de modernização, trazidos pela consolidação das novas repúblicas e pela abertura à economia de mercado. Tudo parece indicar que música popular tenha sido uma categoria relevante em nosso contexto musical só a partir da passagem do século XIX para século XX, existindo uma sintomática ausência do termo nos escritos oitocentistas.

Quando a visão de mundo romântica advogou pela recuperação e pela valorização da nomeada “cultura popular”, a grande divisão música profana / música sacra, usada durante o período colonial, perdeu seu protagonismo e deu lugar a outro tipo de fragmentação, mais de acordo com as novas circunstâncias: música popular / música erudita. Uma das particularidades que influenciaram no surgimento dessa nova divisão foi a criação, no século XIX, das instituições de ensino musical. Estas acabaram acentuando a diferenciação entre, por um lado, um músico formado dentro de seus muros e próximo da tradição musical europeia escrita - considerada símbolo de progresso - e, por outro lado, um músico formado no ambiente musical tradicional — não institucionalizado - e caracterizado pela reprodução do conhecimento mediante mecanismos orais.

Mário de Andrade, assim como a maioria dos autores estudados, nasceu nos últimos anos do século XIX e se formou sob a visão de mundo romântica. Foi um grupo de jovens autodidatas no ofício da pesquisa musical que, de forma eclética, valeram-se da literatura musical disponível para alimentar seus trabalhos e construir suas referências teóricas, comumente implícitas em seus estudos. O ambiente intelectual e cultural de finais do século XIX contribuiu para que os princípios românticos influenciassem, em diferentes medidas, nas definições de música popular que os estudiosos cunharam tacitamente.

Graças aos contatos entre alguns colegas latino-americanos, por meio de correspondência, intercâmbio bibliográfico ou colaboração no Boletín Latinoamericano de Música, pode-se pensar que as complexidades do conceito de música popular caminharam sigilosamente em suas leituras dos trabalhos produzidos em outros cantos do continente. Talvez não seja errado ver na comunicação que alguns pesquisadores estabeleceram com Mário de Andrade, um exemplo do reconhecimento que teve o pensamento do musicólogo brasileiro entre seus colegas e 
um indício de que, implicitamente, sua concepção do popular foi acolhida ou compartilhada - em alguma medida - por outros pesquisadores da América Latina.

A maioria dos autores aqui estudados partiu da adoção da definição de música popular dada pelo romantismo, entendida principalmente como música ligada ao âmbito rural, onde se conservava autônoma e pura. As características utópicas atribuídas à cultura popular pelo romantismo, foram transpostas para o conceito de música popular, o qual passou a caracterizar um tipo de música considerada como natural, tradicional e anônima. Essa definição de música popular fortaleceu-se no contexto latino-americano graças à credibilidade legada ao folclore durante a primeira metade do século XX, já que os estudos de folclore apresentavamse como um auxílio para a formação das identidades nacionais e como antídoto dos efeitos destrutivos da modernização.

Tudo indica que o forte clima nacionalista da primeira metade do século XX também teria influenciado a formulação do conceito de música popular e, certamente, o nacionalismo musical conferiu-lhe a legitimidade de identidade nacional. O ímpeto do nacionalismo musical sobre o conceito música popular pode ser observado no fato de que muitos autores trataram como sinônimos os adjetivos nacional e popular, posto que se pensava em uma relação simbiótica entre eles.

Mário de Andrade era um modernista militante e, portanto, um profundo crítico do pensamento oitocentista. Como tal, cuidou de incorporar as interpretações românticas a suas reflexões. Não obstante, observou-se que o musicólogo adotou a dicotomia entre música popular e música erudita, e que esteve convencido de que a primeira devia alimentava a segunda, para convertê-la em música artística nacional, ideia defendida por seus contemporâneos.

Ao pensar que as tradições populares deviam ser antigas para poder ser legítimas - como argumentava o romantismo europeu - os escritores latinoamericanos assumiram o estudo da música popular do passado, para indicar quais eram os elementos musicais genuínos, sobre os quais as obras musicais nacionalistas poderiam inspirar-se. Ao ir ao passado, alguns autores mantiveram a sinonímia entre popular e nacional, incidindo em flagrantes anacronismos. Outros autores, como Mário de Andrade, reconheceram que a música chamada nacional só existiu depois 
que as repúblicas e o mundo moderno configuraram-se, enquanto que a música popular era "própria de todos os tempos". No dizer do musicólogo brasileiro, o fato de que todas as fontes documentais não tenham chegado ao presente, dificultava o estudo da música popular antiga.

Tanto o nacionalismo quanto o romantismo permearam o conceito de música popular, especialmente por meio dos estudos de folclore. Nos primeiros anos do século XX, na América Latina, a palavra folclore foi usada para se referir a esse campo do saber e, pouco depois, popular e folclórico começaram a ser usados como adjetivos sinônimos, relativos a um mesmo tipo de música. Entretanto, no pensamento de Mário de Andrade, essa sinonímia não significou que ele assumisse, dentro de seu conceito de música popular, todas as particularidades que o folclore atribuía-lhe. A principal diferença foi a inclusão de certos fenômenos musicais urbanos dentro da categoria. Ele também considerou que o folclórico era temporal, ou seja, intrinsecamente mutável, que servia para nutrir a obra criadora do artista e que não era a sua beleza o que justificava seu estudo, mas sim o interesse científico.

Também se suspeita que o conceito música popular de Mário de Andrade encerrasse outras características pelas quais o folclore não se interessou, como é o caso de algumas particularidades musicais. A esse respeito, parece que a importância dada pelo escritor paulistano ao elemento rítmico na música em geral, levou-o a pensar que a música popular tinha um nível dinamogênico muito alto. Dita dinamogenia marcada, explicava-a ao considerar que a música popular nascia de estados físico-psíquicos humanos particulares.

É importante observar que essa ligação entre a música popular e a psique humana também levou Mário de Andrade a pensar que esse tipo de música enquadrava-se na categoria de música interessada, ou seja, de uma música com uma utilidade coletiva ou comunitária. Por sua vez, e como consequência desse caráter potencialmente coletivo, o escritor esclareceu que a música popular não nascia da necessidade individual de um criador e, por isso, seu autor era facilmente esquecido pela sociedade. Além disso, esse caráter comunitário outorgava-lhe estruturas musicais repetidas e memorizáveis para não ser esquecida. Por esse motivo, na 
música popular eram frequentes a monodia e as estruturas de repetição, como o rondo.

No final da vida, e depois de aprofundar os estudo dos processos de folclorização e popularização da música, parece que Mário de Andrade inclinava-se a pensar que, basicamente, a música popular era constituída por certas estruturas musicais sobre as quais se faziam variações, tanto diacrônica quanto sincronicamente, e que tinha um repertório limitável de peças musicais.

Enquanto o nacionalismo e o romantismo defendiam a ideia utópica de música popular, desenvolviam-se importantes processos de configuração das culturas urbanas no continente latino-americano, que iriam problematizar o conceito. A configuração dessas culturas urbanas gerou um novo contexto musical que, somado à acolhida dos modernos meios eletrônicos de comunicação, serviu de base para a formação de um tipo de música popular, paulatinamente diferenciada daquela herdada do século XIX. O desenvolvimento da música, que cresceu dentro dessas culturas urbanas, influenciou o conceito romântico de música popular e contribuiu para a construção da atual polissemia do conceito.

Embora a precoce indústria discográfica tenha gravado e comercializado a música que habitualmente circulava no meio, aos poucos, a música gravada deixou de ser copia fiel desses contextos e sofreu mudanças que acabaram dando-lhe uma sonoridade particular e nova. Nessa mudança sonoras, talvez tenha havido a influência de dois fatores: por um lado, o fato de que os processos técnicos de gravação priorizaram certa instrumentação e interpretação do repertório a ser gravado. Por outro, o descobrimento da indústria fonográfica de que suas vendas aumentavam quando os arranjos da música eram feitos com base nos estilos norteamericanos, em vias de internacionalização. Dessa forma, a industria discográfica foi dando um tênue matiz de homogeneidade à toda a sua produção. Além disso, pode-se pensar que a sonoridade dessa música gravada refletiu, sem purismos, o fato de que os limites entre as tradições musicais rurais e urbanas, nacionais e internacionais eram mais teóricos do que práticos, e que os músicos ultrapassavam essas fronteiras com facilidade e se alimentavam de todas as tradições. 
O conceito de música popular, proposto pelo folclore, desconheceu fenômenos como a reapropriação das tradições rurais pelo meio urbano, as quais eram difundidas e patrocinadas pela indústria fonográfica. Também fechou seus olhos e ouvidos aos fenômenos de difusão e influência da música erudita e popular urbana no meio rural. Os limites teóricos entre o rural e o urbano fizeram com que alguns escritores, como Mário de Andrade e Carlos Vega, sentissem a estreiteza do conceito música popular, de ascendência folclórica, e refletissem sobre alguns de seus aspectos.

Mário de Andrade, em fins da década de 1930, identificou que os ambientes rurais e urbanos não estavam bem definidos na América Latina, dada a existência de âmbitos intermediários, e usou esporadicamente a expressão música popular urbana para se referir a gêneros como o choro, a modinha e o maxixe, que eram populares e citadinos. Além disso, Mário de Andrade propôs a diferenciação entre dos tipos de música popular urbana: uma popular folclórica e outra popularesca, ou feita à maneira popular.

$\mathrm{Na}$ intimidade de seu gabinete, parece que o musicólogo brasileiro também notou que a música popular difundida na década de 1930 pelos discos não era a música que habitualmente se tinha nomeado de popular e que, na realidade, podiamse distinguir dois tipos de produções discográficas: uma, de "discos científicos" e, outra, de "discos comerciais". Nos primeiros, parecia encontrar a música popular que lhe era familiar, aquela usada no campo e na cidade para o trabalho, a diversão e a reza. Nos últimos, parece que encontrava outra música popular, uma que mantinha somente os elementos melódico-rítmicos originais, já que a orquestração, harmonização e interpretação podiam ser externas à tradição e impostas pela lógica de mercado da indústria discográfica. Em última instância, parece que Mário de Andrade continuou a nomear esta última também de música popular porque, apesar das suas mudanças musicais, ela mantinha uma utilidade: participar do mercado. Essa conceituação acerca do científico e do comercial na música popular gravada, ficou guardada em rascunho entre seus manuscritos e não foi explicitada em suas publicações. 
A música inicialmente popular-folclórica, mas modificada pelas modas internacionais, difundidas ou impostas pela indústria discográfica, foi duramente criticada e desvalorizada pelo romantismo e pelo nacionalismo, posto que viam nela a influência de dois dos maiores males da modernidade: a mercantilização e a mecanização. Sintoma desse desprezo foi o uso, por parte de alguns autores, do adjetivo populachera, em espanhol, e popularesca, em português, para se referir à música popular gravada, uso que se acentuou a meados do século XX.

Com o transcorrer do século XX, surgiram maiores tensões entre o projeto nacionalista romântico e a música de evidente viés comercial e internacional. Parece que o início da segunda metade da centúria conheceu as posições mais radicais a respeito. Nesse contexto de crescente hostilidade no plano teórico, entre uma música popular rural - útil ao nacionalismo - e outra música popular midiatizada - que proporcionava grandes ganhos às companhias discográficas -, Mário de Andrade usou as palavras submúsica e música popularesca para se referir a dois tipos diferentes de música. Graças aos ataques de Mário de Andrade ao meio artístico, no final da sua vida, a historiografia tem visto no uso dessas expressões um sinal de menosprezo pela música midiática, por ser contrária a seu projeto nacional.

Independentemente do grau de avaliação de Mário de Andrade em relação à música popular gravada, observou-se que ele denominou com o adjetivo popularesca, basicamente à música "feita à maneira popular", intermediária entre o popular e o erudito, ou entre o popular tradicional e o popular urbano. Nessa medida, o autor qualificou como popularescas, tanto obras de compositores eruditos quanto aquelas gravadas nos discos de acetato. Entretanto, no fim da vida, quando a música popular dos discos adquiria uma fisionomia própria, ele usou, maioritariamente, o vocábulo música popularesca para caracterizar esse repertório.

Por outro lado, com o epíteto de submúsica, parece que Mário de Andrade referiu-se a uma música que lhe causava grande desgosto por lançar mão de fórmulas musicais cuja aceitação, por parte do público, já era comprovada e, em consequência, por sacrificar sua qualidade em vista do "aplauso fácil". Aparentemente, essa submúsica esteve representada, na música erudita, pelas peças virtuosísticas e, na música popular midiatizada, pela música que se restringiu a repetir fórmulas bem- 
sucedidas comercialmente. Na opinião do autor, essas peças musicais colonizaram a produção discográfica de seus últimos anos.

Em síntese, a história da construção do conceito de música popular, entre o final do século XIX e durante a primeira metade do século XX, foi um processo para o qual convergiram: a influência do romantismo como crítica às mudanças trazidas pela modernidade; a força política e cultural do Estado nacional; a pujança do nacionalismo no pensamento musical que procuravam criar identidades a partir da utopia do popular, e a consolidação das culturas urbanas com novos fenômenos musicais, trazidos pelos meios eletrônicos de comunicação modernos. A maneira como essas variantes conjugaram-se, ao longo do tempo, no significado de música popular, foi assimétrica, calada e funda. Mas, em meados do século XX, as tensões já criadas pela separação teórica entre urbano, rural e erudito, evidenciaram o caráter polissêmico do conceito e a não compatibilidade política entre uma música popularfolclórica - símbolo de nacionalidade - e uma música popular-internacional símbolo de modernidade - cobertas sob o mesmo epíteto de música popular. Além disso, enquanto a música folclórica ficou estabelecida com características que passaram a distingui-la e delimitaram sua prática cultural, por sua parte, a música popular urbana apresentou inúmeros caminhos que exigiram novas interpretações que dessem conta de seus conflitos e tensões. Daí em diante, virá uma outra história de lutas explícitas para definir o conceito e, com ele, a legitimidade de certos discursos historiográficos, culturais e políticos. 


\section{REFERÊNCIAS}

Agüero, Gaspar. Consideraciones sobre la música popular cubana: (a) sus defectos (b) sus bellezas. La Habana: Imprenta "La Propagandista", 1922.

Aharonián, Coriún. "Carlos Vega y la teoría de la música popular. Un enfoque latinoamericano en un ensayo pionero." Revista Musical Chilena. v. 51, no. 188, (julio) 1997, pp. 61-74.

Allen, Warren Dwight. Philosophies of Music History. A Study of General Histories of Music. [1939] 2a ed., New York: Dover Publications Inc, 1962.

Almeida, Renato. História da música brasileira. Rio de Janeiro: Briguiet, 1926.

Almeida, Renato. História da música brasileira. [1926] 2a ed., Rio de Janeiro: F. Briguiet, 1942.

Almeida, Renato. "Música folclórica e música popular." Boletim da Comissão Gaúcha de Folclore. v. 22, 1958, p. 13.

Alvarenga, Oneyda. "Mário de Andrade e a música." Oneyda Alvarenga (ed.) Mário de Andrade, um pouco. Rio de Janeiro / São Paulo: SCET Livraria José Olympio Editora, 1974. pp. 39-73.

Amaral, Amadeu. "O popular em matéria folclórica." Paulo Duarte (ed.) Tradições populares. São Paulo: Instituto Progresso Editorial S. A., 1948. pp. 15-16.

Ambrosetti, Juan Bautista. Supersticiones y Leyendas. Buenos Aires: La cultura argentina, 1917.

Andrade, Mario de. O disco popular no Brasil. São Paulo: Aquivo do Instituto de Estudos Brasileiros (IEB - USP), Fundo Mário de Andrade, Caixa 057, MAMMA-040, s.d.

Andrade, Mario de. O disco popular no Brasil. São Paulo: Aquivo do Instituto de Estudos Brasileiros (IEB - USP), Fundo Mário de Andrade, Série Manuscritos, Caixa 057, MA-MMA-040, s.d.

Andrade, Mario de. Obra imatura. [1960] Telê Ancona Lopez (ed.), Rio de Janeiro: Agir, 2009.

Andrade, Mario de. Rádio Documentação - Definições. São Paulo: Aquivo do Instituto de Estudos Brasileiros (IEB - USP), Fundo Mário de Andrade, Caixa 171, MA-MMA-103, s.d.

Andrade, Mário de. Dicionário Musical Brasileiro. Oneyda Alvarenga, et al. (eds.) Belo Horizonte, Brasília, São Paulo: Itatiaia; Ministério da Cultura; Instituto de Estudos Brasileiros EDUSP, 1989. 
Andrade, Mário de. "As bachianas." [1938] In: Oneyda Alvarenga (ed.) Música, doce música. Estudos da crítica e folclore. Sao Paulo: Livraria Martins Editora, 1976. pp. 273-277.

Andrade, Mário de. "Atualidade do Chopin." [1942] In: O baile das quatro artes. São Paulo: Livraria Martins Editora, 1963. pp. 135-166.

Andrade, Mário de. "Camargo Guarnieri." [1940] In: Oneyda Alvarenga (ed.) Música, doce música. Estudos da crítica e folclore. São Paulo: Livraria Martins Editora, 1976. pp. 324-328.

Andrade, Mário de. "Canções brasileiras I." Diario Nacional, (22 dez., 1927). 2 pp.

Andrade, Mário de. "Cândido Inácio da Silva e o lundu." [1945] Latin American Music Review. v. 20, no. 2, (Autumn - Winter) 1999, pp. 215-233.

Andrade, Mário de. "Carnaval tá aí." [1931] In: Telé Ancona Lopez (ed.) Taxi e Crônicas no Diário Nacional. São Paulo: Duas Cidades. Secretaria da Cultura, Ciência e Tecnologia, 1976. pp. 321-323.

Andrade, Mário de. "A carta de Alba." [1943] In: Jorge Coli (ed.) Música final. Mário de Andrade e sua coluna jornalística Mundo musical. Campinas: Editora da Unicamp, 1998. pp. 60-64.

Andrade, Mário de. "Chiquinha Gonzaga." [1940] In: Oneyda Alvarenga (ed.) Música, doce música. Estudos da crítica e folclore. São Paulo: Livraria Martins Editora, 1976. pp. 329-333.

Andrade, Mário de. Compêndio de história da música. São Paulo: I Chiarato \& Cia, 1929.

Andrade, Mário de. "Crítica do gregoriano." [1926] In: Oneyda Alvarenga (ed.) Música, doce música. Estudos da crítica e folclore. São Paulo: Livraria Martins Editora, 1976. pp. 25-38.

Andrade, Mário de. "Cuba, outra vez." [1932] In: Telé Ancona Lopez (ed.) Taxi e Crônicas no Diário Nacional. São Paulo: Duas Cidades. Secretaria da Cultura, Ciência e Tecnologia, 1976. pp. 487-488.

Andrade, Mário de. "Cultura artística." [1934] In: Paulo Castagna (ed.) Música e Jornalismo: Diário de S. Paulo. São Paulo: Edusp/Hucitec., 1993. pp. 137-138.

Andrade, Mário de. "Cultura artística - Julieta Teles de Meneses." [1934] In: Paulo Castagna (ed.) Música e Jornalismo: Diário de S. Paulo. São Paulo: Edusp/ Hucitec, 1993. p. 252.

Andrade, Mário de. Danças dramáticas do Brasil. Oneyda Alvarenga (ed.) Obras Completas de Mario de Andrade, Vol. 3, São Paulo: Livraria Martins Editora, 1959.

Andrade, Mário de. "Dançãs dramáticas iberobrasileiras." Música do Brasil. Curitiba: Guaira, 1941. pp. 42-79. 
Andrade, Mário de. "Dinamogenias políticas." [1930] In: Oneyda Alvarenga (ed.) Música, doce música. Estudos da crítica e folclore. São Paulo: Livraria Martins Editora, 1976. pp. 104-111.

Andrade, Mário de. "Discos e fonógrafos." [1928] In: Flávia Camargo Toni (ed.) $A$ música popular brasileira na vitrola de Mário de Andrade. São Paulo: SESC, SENAC, 2004. pp. 267-268.

Andrade, Mário de. Discoteca nacional. São Paulo: Arquivo Instituto de Estudos Brasileiros (IEB-USP), Fundo Mário de Andrade, Série Manuscritos, Caixa 058, MA-MMA-042, s.d.

Andrade, Mário de. "Do meu diário." [1945] In: Jorge Coli (ed.) Música final. Mário de Andrade e sua coluna jornalística Mundo musical. Campinas: Editora da Unicamp, 1998. pp. 178-182.

Andrade, Mário de. "Do meu diário (B)." [1944] In: Jorge Coli (ed.) Música final. Mário de Andrade e sua coluna jornalística Mundo musical. Campinas: Editora da Unicamp, 1998. pp. 155-159.

Andrade, Mário de. Ensaio sobre a música brasileira. [1928] 3 $3^{\mathrm{a}}$ ed. Obras Completas de Mario de Andrade, Vol. IV, São Paulo: Livraria Martins Editora, 1972.

Andrade, Mário de. "Ernesto Nazaré." [1926] In: Oneyda Alvarenga (ed.) Música, doce música. Estudos da crítica e folclore. São Paulo: Livraria Martins Editora, 1976. pp. 121-130.

Andrade, Mário de. "Ernesto Nazareth." [1940] In: Oneyda Alvarenga (ed.) Música, doce música. Estudos da crítica e folclore. São Paulo: Livraria Martins Editora, 1976. pp. 319-323.

Andrade, Mário de. A escrava que não é Isaura. São Paulo: Livraria Lealdade, 1925.

Andrade, Mário de. "Evolução social da música no Brasil." [1941] In: Oneyda Alvarenga (ed.) Aspectos da música brasileira. Belo Horizonte - Rio de Janeiro: Villa Rica Editoras reunidas limitada, 1991. pp. 11-31.

Andrade, Mário de. "«Fantasia» de Walt Disney." [1941] In: O baile das quatro artes. São Paulo: Livraria Martins Editora, 1963. pp. 67-85.

Andrade, Mário de. "Gravação nacional." [1930] In: Telé Ancona Lopez (ed.) Taxi e crônicas no Diário nacional. São Paulo: Duas Cidades. Secretaria da Cultura, Ciência e Tecnologia, 1976. pp. 235-238.

Andrade, Mário de. "Guiomar Novais." [1933] In: Paulo Castagna (ed.) Música e Jornalismo: Diário de S. Paulo. São Paulo: Edusp/Hucitec, 1993. pp. 60-61.

Andrade, Mário de. "Herinque Oswald." [1931] In: Oneyda Alvarenga (ed.) Música, doce música. Estudos da crítica e folclore. São Paulo: Livraria Martins Editora, 1976. pp. 168-170.

Andrade, Mário de. "História da música." Diário Nacional, (15 jan., 1930). 7 pp. 
Andrade, Mário de. "Influencia portuguesa nas rodas infantis do Brasil." [1929] In: Oneyda Alvarenga (ed.) Música, doce música. Estudos da crítica e folclore. São Paulo: Livraria Martins Editora, 1976. pp. 81-94.

Andrade, Mário de. Introdução à estética musical. Flávia Camargo Toni (ed.), São Paulo: HUCITEC, 1995.

Andrade, Mário de. "Kreisler." [1935] In: Paulo Castagna (ed.) Música e Jornalismo: Diário de S. Paulo. São Paulo: Edusp/Hucitec, 1993. pp. 306-307.

Andrade, Mário de. "Laforgue e Satie." [1939] In: Oneyda Alvarenga (ed.) Música, doce música. Estudos da crítica e folclore. São Paulo: Livraria Martins Editora, 1976. pp. 298-302.

Andrade, Mário de. "Lavínia Viotti." [1933] In: Paulo Castagna (ed.) Música e Jornalismo: Diário de S. Paulo. São Paulo: Edusp/Hucitec, 1993. pp. 30-31.

Andrade, Mário de. "Letícia Figueiredo." [1933] In: Paulo Castagna (ed.) Música e Jornalismo: Diário de S. Paulo. São Paulo: Edusp/Hucitec, 1993. p. 97.

Andrade, Mário de. "Lourenço Fernandez (Sonatina)." [1931] In: Oneyda Alvarenga (ed.) Música, doce música. Estudos da crítica e folclore. São Paulo: Livraria Martins Editora, 1976. pp. 179-181.

Andrade, Mário de. "Luciano Gallet. Canções brasileiras." [1927] In: Oneyda Alvarenga (ed.) Música, doce música. Estudos da crítica e folclore. São Paulo: Livraria Martins Editora, 1976. pp. 171-178.

Andrade, Mário de. "Lundu do escravo." [1928] In: Oneyda Alvarenga (ed.) Música, doce música. Estudos da crítica e folclore. São Paulo: Livraria Martins Editora, 1976. pp. 74-80.

Andrade, Mário de. "Marcelo Tupinambá." [1924] In: Oneyda Alvarenga (ed.) Música, doce música. Estudos da crítica e folclore. São Paulo: Livraria Martins Editora, 1976. pp. 115-120.

Andrade, Mário de. "Marcelo Tupinambá." Diário Nacional, (25 ago., 1927). 2 pp.

Andrade, Mário de. Melodias do boi e outras peças. Oneyda Alvarenga (ed.) Obras Completas de Mario de Andrade, São Paulo: Duas Cidades - Brasília INL, 1987.

Andrade, Mário de. "A modinha e Lalo." [1941] In: Oneyda Alvarenga (ed.) Música, doce música. Estudos da crítica e folclore. São Paulo: Livraria Martins Editora, 1976. pp. 339-343.

Andrade, Mário de. Modinhas Imperiais. [1930] Obras Completas de Mario de Andrade, Vol. XIX, Sao Paulo: Livraria Martins Editora, 1964.

Andrade, Mário de. "Música brasileira." Correio Musical Brasileiro. v. 4, 1921, pp. 5-6.

Andrade, Mário de. "Música brasileira." [1942] In: Oneyda Alvarenga (ed.) Música, doce música. Estudos da crítica e folclore. São Paulo: Livraria Martins Editora, 1976. pp. 354-358. 
Andrade, Mário de. Música de feitiçaria no Brasil. Oneyda Alvarenga (ed.) Obras Completas de Mario de Andrade, Vol. XIII, São Paulo: Livraria Martins editora, 1963.

Andrade, Mário de. "A música e a canção populares no Brasil. Ensaio críticobibliográfico." [1936] In: Oneyda Alvarenga (ed.) Ensaio sobre a música brasileira. São Paulo: Livraria Martins Editora, 1972. pp. 162-188.

Andrade, Mário de. "A música no Brasil." [1931] In: Oneyda Alvarenga (ed.) Música, doce música. Estudos da crítica e folclore. São Paulo: Livraria Martins Editora, 1976. pp. 17-24.

Andrade, Mário de. "Música popular." [1939] In: Oneyda Alvarenga (ed.) Música, doce música. Estudos da crítica e folclore. São Paulo: Livraria Martins Editora, 1976. pp. 278-282.

Andrade, Mário de. "Música universitária." [1944] In: Jorge Coli (ed.) Música final. Mário de Andrade e sua coluna jornalística Mundo musical. Campinas: Editora da Unicamp, 1998. pp. 160-164.

Andrade, Mário de. Música, doce música. Estudos da crítica e folclore. [1933] $3^{\mathrm{a}}$ ed. Oneyda Alvarenga (ed.) Obras completas de Mário de Andrade, Vol. VII, São Paulo: Livraria Martins Editora, 1976.

Andrade, Mário de. "Músicas políticas I." [1943] In: Jorge Coli (ed.) Música final. Mário de Andrade e sua coluna jornalística Mundo musical. Campinas: Editora da Unicamp, 1998. pp. 122-125.

Andrade, Mário de. "Nacionalismo musical." [1939] In: Oneyda Alvarenga (ed.) Música, doce música. Estudos da crítica e folclore. São Paulo: Livraria Martins Editora, 1976. pp. 293-297.

Andrade, Mário de. Namoros com a medicina. [1939] $3^{\mathrm{a}}$ ed. Coleccion Obras completas Mario de Andrade, Vol. IX, São Paulo: Livraria Martins Editores, 1972.

Andrade, Mário de. "Número especial." [1944] In: Jorge Coli (ed.) Música final. Mário de Andrade e sua coluna jornalística Mundo musical. Campinas: Editora da Unicamp, 1998. pp. 147-150.

Andrade, Mário de. "O artista e o artesão." [1938] In: O baile das quatro artes. São Paulo: Livraria Martins Editora, 1963. pp. 9-34.

Andrade, Mário de. O banquete. [1943] Jorge Coli (ed.), São Paulo: Livraria Duas Cidades, 1977.

Andrade, Mário de. "O desnivelamento da modinha." [1941] In: Oneyda Alvarenga (ed.) Música, doce música. Estudos da crítica e folclore. São Paulo: Livraria Martins Editora, 1976. pp. 344-348.

Andrade, Mário de. "O folclore no Brasil." [1949] In: Rubens Borba de Moraes, et al. (ed.) Manual Bibliográfico de Estudos Brasileiros. Rio de Janeiro: Gráfica editora Souza, 1949. pp. 421-469. 
Andrade, Mário de. "O fonógrafo." [1928] In: Flávia Camargo Toni (ed.) A música popular brasileira na vitrola de Mário de Andrade. São Paulo: SESC, SENAC, 2004. pp. 263-265.

Andrade, Mário de. "O romance do Veludo." [1928] In: Oneyda Alvarenga (ed.) Música, doce música. Estudos da crítica e folclore. São Paulo: Livraria Martins Editora, 1976. pp. 67-73.

Andrade, Mário de. "O samba rural paulista." [1937] In: Oneyda Alvarenga (ed.) Aspectos da música brasileira. Belo Horizonte, Rio de Janeiro: Vila Rica Editoras Reunidas Ltda, 1991. pp. 112-185.

Andrade, Mário de. O turista aprendiz. [1928-9] 2ª ed. Telê Ancona Lopez (ed.), São Paulo: Duas Cidades / SCCT, 1983.

Andrade, Mário de. "Origens do fado." [1930] In: Oneyda Alvarenga (ed.) Música, doce música. Estudos da crítica e folclore. São Paulo: Livraria Martins Editora, 1976. pp. 95-99.

Andrade, Mário de. "Originalidade do maxixe." Ilustração musical. v. 2, (set.) 1930, p. 45.

Andrade, Mário de. "Orquestra de cordas." [1933] In: Paulo Castagna (ed.) Música e Jornalismo: Diário de S. Paulo. São Paulo: Edusp/Hucitec, 1993. pp. 54-55.

Andrade, Mário de. Os cocos. Oneyda Alvarenga (ed.), São Paulo: Liv Duas Cidades - Instituto Nacional do Livro; Fundação Nacional Pró-memoria, 1984.

Andrade, Mário de. Pequena história da música. [1942] 4ª ed. Obras Completas de Mario de Andrade, Vol. VIII, São Paulo: Livraria Martins Editora, 1953.

Andrade, Mário de. "Pianolatria." Klaxon. v. 1, 1922, p. 8.

Andrade, Mário de. "Prof. Curt Lange." [1934] In: Paulo Castagna (ed.) Música e Jornalismo: Diário de S. Paulo. São Paulo: Edusp/Hucitec, 1993. p. 266.

Andrade, Mário de. "Prof. Curt Lange." [1934] In: Paulo Castagna (ed.) Música e Jornalismo: Diário de S. Paulo. São Paulo: Edusp/Hucitec, 1993. pp. 264-165.

Andrade, Mário de. "Prof. Curt Lange." [1934] In: Paulo Castagna (ed.) Música e Jornalismo: Diário de S. Paulo. São Paulo: Edusp/Hucitec, 1993. pp. 262-263.

Andrade, Mário de. "A pronúncia cantada e o problema do nasal brasileiro através dos discos." [1938] In: Oneyda Alvarenga (ed.) Aspectos da música brasileira. Belo Horizonte, Rio de Janeiro: Villa Rica Editoras Reunidas Ltda, 1991. pp. 95-111.

Andrade, Mário de. "Quarteto Aguilar." [1933] In: Paulo Castagna (ed.) Música e Jornalismo: Diário de S. Paulo. São Paulo: Edusp/Hucitec., 1993. pp. 26-27. 
Andrade, Mário de. "Quarto de tom." [1939] In: Oneyda Alvarenga (ed.) Música, doce música. Estudos da crítica e folclore. São Paulo: Livraria Martins Editora, 1976. pp. 288-292.

Andrade, Mário de. "Romantismo musical." [1941] In: O baile das quatro artes. São Paulo: Livraria Martins Editora, 1963. pp. 37-66.

Andrade, Mário de. "Scarlatti." [1943] In: Jorge Coli (ed.) Música final. Mário de Andrade e sua coluna jornalística Mundo musical. Campinas: Editora da Unicamp, 1998. pp. 70-73.

Andrade, Mário de. "Shostacovich." [1945] In: Jorge Coli (ed.) Música Final. Mário de Andrade e sua coluna jornalística Mundo musical. São Paulo: Editora da Unicamp, 1998. pp. 396-408.

Andrade, Mário de. "Taxi: Pessimismo divino." [1929] In: Telé Ancona Lopez (ed.) Taxi e Crônicas no Diário Nacional. São Paulo: Duas Cidades. Secretaria da Cultura, Ciência e Tecnologia, 1976. pp. 99-98.

Andrade, Mário de. "Taxi: Sinhô." [1929] In: Telé Ancona Lopez (ed.) Taxi e Crônicas no Diário Nacional. São Paulo: Duas Cidades. Secretaria da Cultura, Ciência e Tecnologia, 1976. pp. 103-104.

Andrade, Mário de. "Terapêutica musical." [1939] In: Oneyda Alvarenga (ed.) Namoros com a medicina. São Paulo: Livraria Martins Editores, 1972. pp. 13-62.

Andrade, Mário de. "Um projeto de Mário de Andrade e Na Pancada do Ganzá: Prefácio." Arte em Revista. v. 2, no. 3, (marzo) 1980, pp. 52-58.

Andrade, Mário de. "Vera Janacopulos." [1933] In: Paulo Castagna (ed.) Música e Jornalismo: Diário de S. Paulo. São Paulo: Edusp/Hucitec, 1993. p. 59.

Andrade, Mário de, Música de feitiçaria no Brasil. Oneyda Alvarenga (ed.) Obras Completas de Mario de Andrade. São Paulo: Livraria Martins editora, 1963.

Aretz, Isabel. Historia de la etnomusicologia en América Latina. Desde la época precolombina hasta nuestros días. Caracas: FUNDEC - CONAC - OEA, 1991.

Aretz, Isabel. Síntesis de la etnomusicología en América Latina., Caracas: Monte Avila Editores, 1980.

Arinos, Affonso. "A música popular." Kosmos. v. 2, no. 4, (abril) 1905.

Arquivo do Instituto de Estudos Brasileiros. Catálogo Discos Mário de Andrade. Instituto de Estudos Brasileiros IEB-USP, Disponível em <www.ieb.usp.br/ catalogo \%5Feletronico > (9 dez. 2011).

Arzeno, Julio. Del folk-lore musical dominicano. Santo Domingo: Imprenta "La Cuna de América" Roques Román, Hnos., 1927.

Assis, Machado de. "O machete." [1878] In: Contos. Uma antologia. São Paulo: Companhia das Letras, 1998. pp. 241-254. 
Assis, Machado de. "Um homem célebre." [1888] In: Várias Histórias. Rio de Janeiro / Belo Horizonte: Livraria Garnier, 1999. pp. 57-72.

Azevedo, Luiz Heitor Corrêa de. "As minhas cartas de Mário de Andrade." Latin American Music Review. v. 1, no. 1, (Spring - Summer) 1980, pp. 92-111.

Azevedo, Luiz Heitor Corrêa de. Saudação a o Lorenzo Fernandez. Rio de Janeiro: Conservatório Brasileiro Música, 1937.

Azevedo, Luiz Heitor Correia de. Dois pequenos estudos de folclore musical. Rio de Janeiro: Typ. do "Jornal do Commercio" Rodrigues \& cia., 1938.

Azevedo, Luiz Heitor Correia de. Escala, ritmo e melodia na música dos indios brasileiros. Rio de Janeiro: Typ. do "Jornal do Commercio" Rodrigues \& cia., 1938.

Azevedo, Luiz Heitor Correia de. "Folklore in the Music Curriculum in Brazil." Music Teachers National Association. 1941, pp. 66-69.

Azevedo, Luiz Heitor Correia de. Relação das óperas de autores brasileiros. Rio de Janeiro: Serviço gráfico do Ministério de Educação e Saude, 1938.

Barbosa, Orestes. Samba: sua história, seus poetas, seus músicos e seus cantores. [1933] 2a ed., Rio de Janeiro: Livraria Educadora, MPB reedições Funarte, 1978.

Bartok, Bela. Escritos sobre música popular. $3^{\mathrm{a}}$ ed. Roberto Raschella (ed.), México: Siglo XXI, 1985.

Bartok, Bela. "La musique populaire Hongroise." La Revue Musicale. v. Deuxième Année, no. 1, (novembre) 1921, pp. 8-22.

Bartok, Bela. "¿Qué es la música popular?" [1931] In: Roberto Raschella (ed.) Escritos sobre música popular. México: Siglo XXI, 1985. pp. 66-70.

Behague, Gerard. "Vega, Carlos." Grove Music Online. Oxford Music Online. 2011 (Disponível em $<$ http://www.grovemusic.com 03/04/2010>).

Bermúdez, Egberto. "Cien años de grabaciones comerciales de música colombiana. Los discos de «Pelón y Marín» (1908) y su contexto." Ensayos. Historia y teoría del arte. v. 17, 2009, pp. 87-136.

Bermúdez, Egberto. "Del humor y el amor: música de parranda y música de despecho en Colombia (II)." Cátedra de Artes. no. 4, 2007, pp. 63-89.

Bermúdez, Egberto. "La Universidad Nacional y la investigación musical en Colombia: tres momentos." Miradas a la Universidad. Bogotá: Dirección Nacional de Divulgación Cultural. Universidad Nacional de Colombia, 2006. pp. 7-83.

Bessa, Virgínia de Almeida. "Um bocadinho de cada coisa»: trajetória e obra de Pixinguinha. História e música popular no Brasil dos anos 20 e 30. (Dissertação) São Paulo: Universidade de São Paulo, Faculdade de Ciências Humanas, 2005. 329 pp. 
Blache, Martha. "El Concepto de Folklore en Hispanoamerica." Latin American Research Review. v. 18, no. 3, 1983, pp. 135-148.

Burke, Peter. Cultura popular na idade moderna. [1978], São Paulo: Companhia das Letras, 1989.

Burke, Peter. O que é a história cultural? [2004], Rio de Janeiro: Jorge Zahar Editores, 2005.

Caicedo y Rojas, José. "Estado actual de la música en Bogotá." [1886] In: Hjalmar de Greiff, et al. (ed.) Textos sobre música y folklore. Bogotá: Instituto Colombiano de Cultura, 1978. pp. 21-32.

Callejo Ferrer, Fernando. Música y músicos portorriqueños. San Juan: Tip Cantera Fernandez \& Co, 1915. (Disponível em <http://ia311311.us.archive.org/0/ items $/$ msicaymsicos00call/msicaymsicos00call.pdf $>$ ).

Callejo y Ocasio, Sandalio. Historia de la música y los músicos. San Juan de Puerto Rico: Tip Mercantil, 1898.

Campos, Rubén. El folklore y la música mexicana. México: Secretaria de Educación pública Talleres gráficos de la Nación, 1928.

Carrizo, Juan Alfonso. Antiguos cantos populares argentinos. Buenos Aires: Impresores Silla hermanos, 1926.

Carrizo, Juan Alfonso. Cancionero popular de Tucuman. [1937], Buenos Aires: A. Baiocco y cía., 1937.

Cascudo, Luís da Câmara, Andrade, Mário de, Moraes, Marcos Antonio de, et al. Câmara Cascudo e Mário de Andrade: cartas 1924-1944. São Paulo: Global Editora, 2010.

Castagna, Paulo. "Música na América portuguesa." José Geraldo Vinci de Moraes, et al. (ed.) História e Música no Brasil. São Paulo: Alameda, 2010. pp. 35-76.

Castañeda, Daniel, e Mendoza, Vicente T. Instrumental precortesiano. Instrumentos de percusion Instrumental precortesiano, México: Imprenta del Museo Nacional de Arqueología, Historia y Etnografía, 1933.

Castex, Eusebio R. Cantos populares. Apuntes lexicográficos. Buenos Aires: Talleres gráficos «La lectura», 1923.

Catálogo de discos Victor: 1927 con material biográfico, anotaciones sobre óperas, fotografias de artistas y otras.... New Jersey: Victor Talking Machine, 1927.

Cavalcanti, Alberto R. Música popular: janela-espelho entre o Brasil e o mundo. (Teses) Brasilia: Univesidade de Brasilia (UnB), Departamento de Sociologia, 2007.

Chartier, Roger. "«Cultura popular»: retorno a un concepto historiográfico." Manuscrits. Revista d'història moderna. no. 12, (Gener) 1994, pp. 43-62.

Cifuentes Rodriguez, Santos. "La música en Colombia." El correo musical sudamericano. v. 26, (22 septiembre) 1915, pp. 4-5,10-11. 
Coli, Jorge. "Mário de Andrade - Introdução ao pensamento musical." Revista do Instituto de Estudos Brasileiros. no. 12, 1972, pp. 111 - 136.

Coli, Jorge. "Mário de Andrade - Introdução ao pensamento musical." Revista do Instituto de Estudos Brasileiros. no. 12, 1972, pp. 111 - 136.

Contier, Arnaldo D. Brasil Novo. Música, nação e modernidade: os anos 20 e 30. (Teses de livre docência) São Paulo: Universidade de São Paulo FFLCH Fac. de Filosofia Letras e Ciências Humanas, 1988.

Contier, Arnaldo Daraya. "O ensaio sobre a música brasileira: estudo das matizes ideológicos do vocabulário social e técnico-estético - Mário de Andrade, 1928." Revista Música. v. 6, no. 1/6, (maio/nov.) 1995, pp. 75-121.

Cook, Nicholas. De Madonna al canto gregoriano. Una muy breve introducción a la música. [1998], Madrid: Alianza editorial, 2001.

Cortés Polanía, Jaime. La música nacional y popular colombiana en la colección Mundo al día (1924-1938). Bogotá: Universidad Nacional de Colombia, 2004.

Cortés Polanía, Jaime. "El Tango Chocoanita de Anastasio Bolívar: un augurio musical de los años 1920s en Colombia." A Contratiempo, no. 15 (2010) Disponível em <http://acontratiempo.bibliotecanacional.gov.co/?ediciones/ revista-15/> (Julio 2011).

De Certeau, Michel. "A beleza do morto." [1980] In: A cultura no plural. Campinas: Papirus Editora, 1995. pp. 55-85.

Diaz-Ayala Cuban and Latin American Popular Music Collection. Libraries Florida International University - FIU, Disponível em <http://latinpop.fiu.edu/ advsearch.cfm $>$ (nov. 2011).

Dominguez Benejam, Yarelis. Caminos de la musicología cubana. La Habana: Editorial Letras Cubanas, 2000.

Duarte, Paulo. Mário de Andrade por ele mesmo. $2^{\mathrm{a}}$ ed., Sao Paulo: HUCITEC SCT, 1977.

Duque, Ellie Anne. "Emilio Murillo. Compositor colombiano (1880-1942)." Biblioteca Luis Ángel Arango. Banco de la República, Disponível em $<$ http:// www.banrepcultural.org/blaavirtual/musica/blaaaudio/compo/murillo/ indice2.htm>, (20 mayo 2011)

Duque, Ellie Anne. Emirto de Lima (1890-1972) antología: pasillos, danzas y canciones. Bogotá: Fundación de Música, 2001.

Encyclopedic Discography of Victor Recordings. Regents of the University of California, Disponível em $<\mathrm{http}$ ://victor.library.ucsb.edu $>$ (20 oct. 2011).

Eu sou trezentos, sou trezentos e cincoenta. Telê Ancona Lopez (ed.) Rio de Janeiro: Agir, 2008.

Fernandes, Florestan. "Mário de Andrade e o folclore brasileiro." [1946] Revista do Instituto de Estudos Brasileiros. v. 36, 1994, pp. 141-158. 
Figueiredo, Antonio Candido de. Novo diccionario da lingua portuguesa. Lisboa: Tavares Cardoso \& Irmao, 1899.

Franceschi, Humberto. Registro sonoro por meios mecânicos no Brasil. Rio de Janeiro: Studio HMF, 1984.

Friedenthal, Albert. Musik, Tanz und Dichtung bei den Kreolen Amerikas. Berlin: Wilmersdorf, 1913.

Fuentes Matons, Laureano. Las artes en Santiago de Cuba. [1893] Abelardo Estrada (ed.), La Habana: Editorial letras cubanas, 1981.

Fuentes Matons, Laureano. Las artes en Santiago de Cuba. Santiago de Cuba: Ravelo, 1893.

Galindo, Miguel. Nociones de la historia de la música mejicana. Colima: Tip de El Dragón, 1933.

Galvão, Claudio Augusto Pinto. Alguns compassos. Câmara Cascudo e a música (1920/1960). (Teses) São Paulo: Universidade de São Paulo, História Social. Facultade de filosofia, letras e ciências humanas, 2011. 386 p. pp.

García Muñoz, Carmen, e Ruíz, Irma. "Vega, Carlos." Diccionario de la musica española e hispanoamericana. Emilio Casares (ed.) Madrid: Sociedad General de Autores y Editores, 1999.

Giro, Radamés "Ortíz, Fernando." Diccionario enciclopédico de la música cubana. La Habana: Editorial Letras Cubanas, 2007.

Giro, Radamés "Sanchez de Fuentes, Eduardo." Diccionario enciclopédico de la música cubana. La Habana: Editorial Letras Cubanas, 2007.

Gonçalves, Camila Koshiba. Música em 78 rotações: "Discos a todos os preços» na São Paulo dos anos 30. (Dissertação) São Paulo: Universidade de São Paulo, Departamento de História, 2006.

González, Juan Pablo. "Los estudios de música popular y la renovación de la musicología en América Latina: ¿la gallina o el huevo?" Trans - Revista transcultural de Música, v. 12n, (2008) Disponível em <http:// www.sibetrans.com/trans/a 100/los-estudios-de-musica-popular-y-larenovacion-de-la-musicologia-en-america-latina-la-gallina-o-el-huevo $>$ (29 octubre 2011).

González, Juan Pablo. "Musicología popular en América Latina: síntesis de sus logros, problemas y desafíos." Revista Musical Chilena. v. 55, no. 195, (enero) 2001, pp. 38-64.

González, Juan Pablo, e Rolle, Claudio. Historia social de la música popular en Chile, 1890-1950. Santiago: Ediciones Universidad Católica de Chile, 2005.

Grenet, Emilio. Popular Cuban Music. 80 Revised and Corrected Composition, together with an Essay on the Evolution of Music in Cuba. Havana: Carasa, 1939. 
Grenon, Pedro. Nuestra primera musica instrumental: datos historicos. Buenos Aires: Libreria La Cotizadora Económica, 1929.

Guerrero Toro, Juan Agustín. La música ecuatoriana desde su origen hasta 1875. [1876] Fuentes y documentos para la historia de la música del Ecuador, Vol. 1, Quito: Banco Central del Ecuador, 1984.

Guimarães, Francisco (Vagalume). Na roda do samba. [1933] 2a ed., Rio de Janeiro: Funarte, 1978.

Günther, Robert. Las culturas musicales de Latinoamérica en el siglo XIX. Tendencias y perspectivas. Germany: Gustav Bosse Verlag Regensburg, 1982.

Hague, Eleanor. Latin American Music, Past and Present. Santa Ana, Calif: Fine Arts Press, 1934.

Kenney, William Howland. "The Phonograph and the Evolution of «Foreign» and «Ethnic» Records." Recorded Music in American Life: the Phonograph and Popular Memory, 1890-1945. New York: Oxford University Press 1999. pp. 65-88.

Kerman, Joseph. Musicologia. [1985], São Paulo: Livraria Martins Fontes Editora Ltda., 1987.

Kimball, Servicios Estudiantiles. "Efemérides dominicanas." http:// kimballservs.hostei.com/AnalesDominacanos.php?anatas=1932>, (28 out. 2011)

Koselleck, Reinhart. "História dos conceitos e história social." [1979] In: Futuro passado. Contribuição à semántica dos tempos históricos. Rio de Janeiro: Contraponto / PUC-Rio, 2006. pp. 97-118.

Koselleck, Reinhart. "Uma história dos conceitos: Problemas teóricos e práticos." Estudos Históricos. v. 5, no. 10, 1992, pp. 134-146.

Kuss, Malena. "Leitmotive de Charles Seeger sobre Latinoamérica." Revista Musical Chilena. v. 34, no. 151, (Julio - Septiembre) 1980, pp. 29-37.

Laird, Ross. Brunswick Records: New York sessions, 1927-1931. Vol. 2, Westport, Conn.: Greenwood Press, 2001.

Lange, Francisco Curt. Americanismo musical. Montevideo: Instituto de estudios superiores República Oriental de Uruguay, 1934.

Lange, Francisco Curt. "La difusión radio eléctrica como medio de educación de las masas y factor de difusión cultural e científica." Boletín Latinoamericano de Música. v. II, 1936, pp. 131-142.

Lange, Francisco Curt. "Fonografía pedagógica." Anales de Instrución Primaria. v. 1, (abril y junio) 1935.

Lange, Francisco Curt. Impresiones andinas. Montevideo: Editorial Nueva América, 1938.

Lange, Francisco Curt. "La mecanización de la musica y la supersaturación musical." Boletin de la Universidad Nacional de La Plata. no. 4, 1933, pp. 114-129. 
Lange, Francisco Curt. La posición de Nietzsche frente a la guerra, el estado y la raza. Santiago de Chile: Ediciones Ercilla, 1938.

Lange, Francisco Curt. "Sistemas de investigación folklórica y el empleo del acervo folklórico en la música artística." Boletín Latinoamericano de música. v. II, 1936, pp. 143-156.

Latin-american Art Music for the Piano by Twelve Contemporary Composers. Francisco Curt Lange (ed.) New York: G. Schirmer, 1942.

Lavín, Carlos. "La musique des Araucans." La Revue Musicale. no. 5, (mars.) 1925, pp. 247-150.

Lavín, Carlos. "La procession sur les flots." Revue de l'Amerique Latine. v. 16, no. 79, (juillet) 1928, pp. 2-8.

Levi-Strauss, Dina. Instruções práticas para pesquisas de antropologia física e cultural. São Paulo: Departamento de cultura. Prefeitura de São Paulo, 1936.

Lima, Emirto de. Folklore colombiano. Barranquilla: s.e., 1942.

Lima, Emirto de. "A guitarra, instrumento romanceiro." Revista Brasileira de Música. v. 5, no. 1, 1938, pp. 48-59.

Lima, Emirto de. "Várias manifestações folklóricas na costa colombiana do Atlântico." Revista da Associação Brasileira de Música. v. 2, no. 5, 1933, p. 45 .

Lira, Mariza. Brasil sonoro. Generos e compositores populares. Rio de Janeiro: S. A. A. Noite, 1938.

Lira, Mariza. Cânticos militares. Rio de Janeiro: Imprensa Nacional 1942.

Lira, Mariza. Migalhas folklóricas. Rio de Janeiro: Gráfica Laemmert Ltda, 1951.

Lira, Mariza. "O folklore no quadro das ciências antropolôgicas." [1939] In: Migalhas folklóricas. Rio de Janeiro: Gráfica Laemmert Ltda, 1951. pp. 11-12.

Lopez, Telé Ancona. "Cartas de Mário de Andrade." O Estado de S. Paulo, Suplemento Cultura, 19 jun 1983.

Lopez, Telê Ancona. Mário de Andrade: ramais e caminho. São Paulo: Livraria Duas Cidades SECET, 1972.

Löwy, Michael, e Sayre, Robert. Revolta e melancolia. O romantismo na contramão da modernidade. Petrópolis: Editora Vozes, 1995.

Machado, Cacá. O enigma do homem célebre: ambição e vocação de Ernesto Nazareth. São Paulo: Instituto Moreira Salles, 2007.

Mariz, Vasco. Três musicólogos brasileiros. Mário de Andrade, Renato Almeida, Luiz Heitor Correa de Azevedo. Rio de Janeiro/ Brasília: Civilização Brasileira; Instituto Nacional do Livro, 1983.

Marrou, Herni-Irenee. Do conhecimento histórico. [1954] 4ª ed., São Paulo: Martins Fontes, 1975. 
Meierovich, Clara. Vicente T. Mendoza. Artista y primer folclorólogo musical. Ciudad de México: Universidad Nacional Autónoma de México, 1995.

Mello e Souza, Gilda de. O tupi e o alaúde. São Paulo: Duas cidades, 1979.

Mello, Guilherme Theodoro Pereira de. A música no Brasil desde os tempos coloniais até o primeiro decênio da república. Bahia: Typografia de S. Joaquim, 1908.

Mendoza, Vicente T. El romance español y el corrido mexicano; estudio comparativo. México: Ediciones de la Universidad nacional autónoma, 1939.

Merino, Luis. "Francisco Curt Lange (1903-1997): tributo a un americanista de excepción." Revista Musical Chilena. v. 52, no. 189, (enero-junio) 1998, pp. 9-36.

Middleton, Richard, e Manuel, Peter. "Popular Music." Grove Music Online. Oxford Music Online. 2010 (Disponível em <http://www.grovemusic.com 03/ 04/2010>).

Miñana Blasco, Carlos. "Entre el folklore y la etnomusicología. 60 años de estudios sobre la música popular tradicional en Colombia." A contratiempo. Revista de música en la cultura. v. 11, 2000, pp. 36-49.

Moraes, José Geraldo Vinci de. "E «Se você jurar», «Pelo telefone», que estou na Missão de Pesquisas Folclóricas?" Revista USP. v. 87, 2010, pp. 172-184.

Moraes, José Geraldo Vinci de. "História e historiadores da música popular no Brasil." Latin American Music Review. v. 28, no. 2, (december) 2007, pp. 271-299.

Moraes, José Geraldo Vinci de. Metrópole em sinfonia. História, cultura e música popular na São Paulo dos anos 30. São Paulo: Estação Libertade, 2000.

Moraes, José Geraldo Vinci de. "Modulações e novos ritmos na oficina da História." Revista galega de cooperación científica iberoamericana. no. 11, 2005, pp. 49-56.

Moraes, José Geraldo Vinci de. "O Brasil sonoro de Mariza Lira." Temas \& Matizes. no. 10, (2 semestre) 2006, pp. 29-36.

Moraes, José Geraldo Vinci de. "«Samba tem cadência. Digo a verdade. E até já chegou na universidade»." Francisco José Gomes Damasceno (ed.) Experiencias musicais. Fortaleza: Prefeitura Municipal de Fortaleza - PMF / EDUECE, 2008.

Moraes, José Geraldo Vinci de, e Machado, Cacá. "«Música em conserva»: memória e história da música no Brasil." La memoria histórica y sus configuraciones temáticas. Una aproximación interdisciplinaria. Montevideo: Ediciones Cruz del Sur, 2011. pp. 1-24.

Moraes Neto, Prudente de. "História da Música Brasileira, Renato de Almeida, Livraria Briguiet, Rio, 1926." Revista do Brasil. v. 1, no. 1, (setembro) 1926, p. 29. 
Moraes Silva, Antonio de. Diccionario da lingua portugueza - recopilado dos vocabularios impressos ate agora, e nesta segunda edição novamente emendado e muito acrescentado. Lisboa: Typographia Lacerdina, 1813 (Disponível em $<$ http://www.ieb.usp.br/online/index.asp $>$ ).

Morais, Eduardo Jardim. A brasilidade modernista: sua dimensão filosófica. Rio de Janeiro: Edições Graal, 1978.

Moreno, Segundo Luis. "La musica en el Ecuador." El Ecuador en 100 años de independencia. Quito: [s.e.], 1930.

Murakawa, Clotilde de Almeida Azevedo. Antonio de Morais Silva: lexicografo da lingua portuguesa Araraquara, SP Laboratorio Editorial da FCL, UNESP, 2006.

"La música en Cuba (breve monografía histórica)." José Calero, et al. (ed.) Cuba musical. Album-resumen ilustrado de la historia y de la actual situación del arte musical en Cuba. La Habana: Imprenta de Molina, 1929. pp. 19-45.

A música popular brasileira na vitrola de Mário de Andrade. Flávia Camargo Toni (ed.) São Paulo: SESC SENAC, 2004.

Nascentes, Antenor Dicionário etimológico da língua portuguesa. Rio de Janeiro: F. Alves, 1932.

Naves, Santuza Cambraia. O violão azul: modernismo e música popular. Rio de Janeiro: Brasil Fundação Getulio Vargas Editora, 1998.

Newton, Isaac. Diccionario musical. Maceió: Typ Commercial 1904.

Nogueira, Maria Guadalupe Pessoa. Edição anotada da correspondência Mário de Andrade e Renato de Almeida. (Dissertação) São Paulo: Universidade de São Paulo, Teoria literária e Literatura Comparada FFLCH, 2003. 362 pp.

Ortiz, Fernando. La africanía de la música folkórica de Cuba. [1950], Havana: Letras Cubanas, 1993.

Ortiz, Fernando. Los bailes y el teatro de los negros en el folklore de Cuba. [1951], Madrid: Editorial Música Mundana Maqueda, 1998.

Ortiz, Fernando. Los instrumentos de la música afrocubana. [1952], Madrid: Editorial Música Mundana Maqueda, 1996.

Ortiz, Renato. Cultura popular: românticos e folcloristas. São Paulo: Programa de Estudos Pós-Graduados em Ciências Sociais Pontifícia Universidade Católica de São Paulo, 1985.

Osorio, Juan Crisóstomo. Diccionario de música, precedido de la teoría jeneral del arte i especial del piano. Bogotá: Imprenta de Gaitán, 1867.

Osorio, Juan Crisóstomo. "Breves apuntamientos para la historia de la música en Colombia." Repertorio colombiano. v. III, no. 15, 1879, pp. 162-166.

Pereira Salas, Eugenio. Los orígenes del arte musical en Chile. Santiago de Chile: Imprenta Universitaria, 1941. 
Pereira Salas, Eugenio. Notas para la historia del intercambio musical entre las Americas antes del año 1940. Washington: Pan American Unión, Music Division, 1943.

Pérez González, Juliana. "Génesis de los estudios sobre música colonial hispanoamericana: un esbozo historiográfico." Revista Fronteras de la Historia. v. 9, 2005, pp. 281-321.

Pérez González, Juliana. Las historias de la música en Hispanoamérica. Bogotá: Facultad de Ciencias Humanas. Universidad Nacional de Colombia, 2010.

Pinto, Alexandre Gonçalves (Animal). O Choro, Reminiscências dos chorões antigos. [1936], Rio de Janeiro: MPB reedições Funarte, 1978.

Plaza, Ramón de la. Ensayos sobre el arte en Venezuela. [1883], Caracas: Imprenta al Vapor de "La Opinion Nacional", 1983.

Porter, James. "Documentary Recordings in Ethnomusicology: Theoretical and Methodological problems." Association for Recorded Sound Collections Jornal, v. 4n, no. 2 (1974) Disponível em <http://www.arsc-audio.org/ journals/v6/v06n2p3-16.pdf> (

Ramírez, Serafín. La Habana artística. Apúntes históricos. Habana: Imp. del E.M. de la Capitanía General, 1891.

Real Academia Española. Diccionario de la lengua castellana por la Real Academia Española. $12^{\text {a }}$ ed Madrid: Imprenta de D. Gregoria Hernando, 1884 (Disponível em $<$ http://buscon.rae.es/ntlle/SrvltGUILoginNtlle>).

Real Academia Española. Diccionario de la lengua castellana compuesto por la Real Academia Española, reducido a un tomo para su más fácil uso. Madrid: Joaquín Ibarra, 1780 (Disponível em <http://buscon.rae.es/ntlle/ SrvltGUILoginNtlle>).

Real Academia Española. Diccionario manual e ilustrado de la lengua española. Madrid: Espasa - Calpe, 1950.

Sáenz Poggio, José. "Historia de la música guatemalteca desde la monarquía española hasta fines del año 1877." [1878] Anales de la Sociedad de geografía e historia de Guatemala. v. 22, no. 1-2, (marzo - junio) 1947.

Saldívar, Gabriel. Bibliografía mexicana de musicología y musicografía. Vol. 2, México: INBA CENIDIM, 1992.

Saldívar, Gabriel. Historia de la música en México: épocas precortesiana y colonial. México: Editorial Cvltvra, 1934.

Sánchez de Fuentes, Eduardo. El folk-lor en la música cubana. La Habana: Imprenta "El Siglo XX" 1923. (Disponível em <http://ufdc.ufl.edu/UF00073996>).

Sánchez de Fuentes, Eduardo. Folklorismo; artículos, notas y criticas musicales. La Habana: Imprenta Molina y compañía, 1928. 
Santos, Alcino, de Azevedo, Miguel Ângel, Barbalho, Grácio, et al. Discografia brasileira 78 rpm 1902-1964. Vol. 5, Rio de Janeiro: Funarte, 1982. (Disponível em $<$ http://www.canalvirtual.org/servicos.php?uid=21>).

Santos, Gustavo. "De la música en Colombia." [1916] In: Hjalmar de Greiff, et al. (ed.) Textos sobre música y folklore. Bogotá: Instituto Colombiano de Cultura, 1978. pp. 292-302.

Schelling, Vivian. A presença do povo na cultura brasileira: ensaio sobre o pensamento de Mário de Andrade e Paulo Freire. Campinas: Universidade Estadual de Campinas, 1991.

Schianca, Arturo. Historia de la música argentina. Orígen y características. Buenos Aires: Establecimiento gráfico argentino, 1933.

Shawe-Taylor, Desmond. "Recording." Grove Music Online. Oxford Music Online, 2011 (Disponível em <www.oxfordmusiconline.com>).

Slonimsky, Nicolas. South American Composers. New York: Musical America, 1940.

Sooy, Harry O. "Memoir of my Career at Victor Talking Machine Company (1898-1925)." Nicholas Pensiero Collection at the Hagley Library, Disponível em $<$ http://www.davidsarnoff.org/sooyh.html $>$, (8 dez. 2011)

Sooy, Raymond "Memoirs of my Recording and Traveling Experiences for the Victor Talking Machine Company." David Sarnoff Library, Disponível em $<$ http:// www.davidsarnoff.org/soo-maintext.html>, (8 dez. 2011)

Souza, Márcio de. Mágoas do violão: mediações culturais na música de Octávio Dutra (Porto Alegre, 1900-1935). (Teses) Porto Alegre: PUCRS, Facultade de Filosofia e e Ciências Humanas, Doutorado em História, 2010.

Stevenson, Robert. "Vicente T. Mendoza." Journal of the International Folk Music Council. v. 18, 1966, pp. 79-80.

Teixeira, Mauricio de Carvalho. Música em Conserva. Arranjadores e modernistas na criação de uma sonoridade brasileira. (Dissertação) São Paulo: Universidade de São Paulo, Facultade de Filosofia, Letras e Ciencias Humanas, 2001. 160 pp.

Toni, Flávia Camargo. Missão: as pesquisas folclóricas. Mário de Andrade. Missão de Pesquisas Folclóricas. [Sao Paulo]: Sesc; Centro Cultural São Paulo; Secretaria de Cultura, Prefeitura de São Paulo, 2007.

Travassos, Elizabeth. Os mandarins milagrosos. Arte e etnografia em Mário de Andrade e Béla Bartok. Rio de Janeiro: Funarte e Jorge Zahar Editor, 1997.

Uribe Holguín, Guillermo. Vida de un músico colombiano. [1941] 2a ed., Bogotá: Fundación Editorial Epígrafe, 2010.

Valentini, Luisa. Um laboratório de antropologia: o encontro entre Mário de Andrade, Dina Dreyfus e Claude Lévi-Strauss (1935-1938). (Dissertação) São Paulo: Universidade de São Paulo, Faculdade de filosofia, letras e ciencias humanas, 2010. $242 \mathrm{pp}$. 
Vega, Carlos. "Cantos y bailes africanos en el Plata." La Prensa, (16 de octubre, 1933).

Vega, Carlos. Danzas y canciones argentinas. Teorías e investigaciones, un ensayo sobre el tango. Buenos Aires: Establecimiento Gráfico de Eugenio Ferrero, 1936.

Vega, Carlos. "Mesomúsica. Un ensayo sobre la música de todos." Revista Musical Chilena. v. 51, no. 188, (julio) 1997, pp. 75-96.

Vega, Carlos. La música de un códice colonial del siglo XVII. Buenos Aires: Imprenta de la Universidad de Buenos Aires, 1931.

Vega, Carlos. La música popular argentina. Canciones y danzas criollas. Buenos Aires: Imprenta de la Universidad de Buenos Aires, 1941.

Vega, Carlos. Panorama de la música popular argentina. Con un ensayo sobre la ciencia del folklore. Buenos Aires: Lozada S. A., 1944.

Veyne, Paul. "A história conceitual." Jacques Le Goff, et al. (ed.) História: Novos Problemas. Rio de Janeiro: Francisco Alves, 1995. pp. 64-88.

Viana, Hermano. O mistério do samba. Rio de Janeiro: Jorge Zahar Editor, 1999.

Vilhena, Luis Rodolfo. Projeto e Missão. O movimento folclórico brasileiro 1947-1964. Rio de Janeiro: Funarte e Fundação Getulio Vargas Editora, 1997.

Wisnik, José Miguel. Machado maxixe: o caso Pestana. São Paulo: Publifolha, 2008.

Wisnik, José Miguel. O coro dos contrários: a música em torno da Semana de 22. São Paulo: Livraria Duas Cidades, 1977.

Wisnik, José Miguel. "O ensaio impossível." Sergio Miceli, et al. (ed.) Gilda, a paixão pela forma. Rio de Janeiro: Ouro sobre azul, 2007. pp. 209-235.

Zañartu, Sady. El camino de la música chilena: La interesante labor del compositor Carlos Lavin. s.l.: s.n., s.d. 


\section{ANEXO \\ CONTEÚDO DISCO COMPACTO}

1. Piacito de cielo. Bambuco interpretado por Pilar Arcos e Fortunio Bonanova com orquestra, discos Brunswick N40315, de autoria de Emirto de Lima, gravado em 1928.

2. Tú. Habanera interpretada por Claudio García Cabrera e Orquestra, discos Victor No62235, de autoria de Eduardo Sánchez de Fuentes, gravado em 1909 em Havana [Col. Diaz-Ayala FIU].

3. O que há contigo. Samba interpretado por Mário Reis, discos Odeon No10569, de autoria de Ernesto do Santos (Donga), gravado em 1930 [Arquivo IEB-USP / IMS].

4. Toada de mutirão, interpretado por Cornélio Pires com Zé Messias e Parceiros, discos Columbia №20033, gravado em 1930 [Arquivo IEB-USP / IMS].

5. Folia de Reis, interpretado por Cornélio Pires e Foliões de Zé Messias, discos Columbia N²0032, de autoria de Angelino de Oliveria, gravado em 1930 [Arquivo IEB-USP / IMS].

6. Canto de Echu. Macumba interpretada por Getúlio Marinho e Conjunto africano, discos Odeon No10690, de autoria de Elói Antero Dias, gravado em 1931 [Arquivo IEB-USP / IMS].

7. Canto de Ogum. Macumba interpretada por Getúlio Marinho e Conjunto africano, discos Odeon $\mathrm{N}^{\mathrm{o}} 10690$, de autoria de Elói Antero Dias, gravado em 1931 [Arquivo IEB-USP / IMS].

8. Carinhoso. Choro orquestral interpretado por Orquestra Victor Brasileira, discos Victor N³3209, de autoria de Alfredo da Rocha Vianna (Pixinguinha) e João de Barro (Braguinha), gravado em 1929 [Arquivo IEB-USP / IMS].

9. Suspiros. Choro orquestral interpretado por Orquestra Victor Brasileira, discos Victor N³3209, de autoria de Gerald Desmond, gravado em 1929 [Arquivo IEB-USP / IMS].

10. Soñando en mi rondador. Fox-incaico interpretado por Orquestra Terig Tucci, discos Columbia No5459X, de autoria de Julio Cañar gravado em 1936 em Nova Iorque [Col. Diaz-Ayala FIU].

11. Mulambo. Samba interpretado por Silvio Caldas, discos Victor No33301, de autoria de Carlos Cardoso, gravado em 1930 [Arquivo IEB-USP / IMS]. 
12. Mamãe não quer. Samba-canção interpretado por Carmen Miranda e Choro Victor, discos Victor No33263, de autoria de Américo de Carvalho, gravado em 1930 [Arquivo IEB-USP / IMS].

13. Nêgo bamba. Samba-batuque interpretado por Otília Amorim, discos Victor No33413, de autoria de José Aymberê de Almeida, gravado em 1930 [Arquivo IEB-USP / IMS].

14. São Benedito é ôro só. Jongo interpretado por Mota da Mota, discos Victor No33380, de autoria de Mota da Mota, gravado em 1930 [Arquivo IEB-USP / IMS].

15. Mia tu sei (ópera Carmen). Aria interpretada por Antonio Paoli, discos Victor N²92035, de autoria de Georges Bizet, gravado em 1905 em Porto Rico [Col. Diaz-Ayala FIU].

16. Sinhô do Bonfim. Maxixe interpretado por Elpidio L. Dias (Bilu) com Orquestra Victor, discos Victor N 33211 , de autoria de Juracy Camargo, gravado em 1929 [Arquivo IEB-USP / IMS].

17. Pleito en un gramofono. Duo masculino com violão interpretado por Ábrego e Picazo, discos Victor $\mathrm{N}^{\circ} 62037$, de autoria de Ábrego y Picazo, gravado em 1907 em México [Col. Diaz-Ayala FIU].

18. Ô de casa!, interpretado por Batista Jr., discos Columbia №5030, gravado em 1929 (São Paulo) [Gonçalves, 2006]

19. Guaritã de coqueiro. Cantiga do norte do Brasil interpretada por Severino Rangel com os Batutas do Norte, discos Odeon N¹0656, de autoria de Severino Rangel (Ratinho), gravado em 1930 [Arquivo IEB-USP / IMS].

20. Vamos apanhar limão. Toada nortista interpretada por Calazans com coro e seu grupo, discos Odeon $\mathrm{N}^{\circ} 10398$, de autoria de José Luis Rodrigues Calazans (Jararaca), gravado em 1929 [Arquivo IEB-USP / IMS].

21. Escoiêno noiva. Moda da viola interpretada por Cornélio Pires e Caipirada Barretense, discos Columbia N²0.021, de autoria de Cornélio Pires, gravado em 1929 [Arquivo IEB-USP / IMS].

22. Gato cabeçudo. Embolada interpretada por José Luiz Rodrigues Calazans (Jararaca), discos Odeon $\mathrm{N}^{\circ} 10398$, de autoria de Calazans, gravado em 1929 [Arquivo IEB-USP / IMS].

23. Cuidadito compay gallo. Son interpretado por Panchito Riset e Quarteto Caney, discos Columbia No5514-X, de autoria de Antonio Fernandez (Ñico Saquito), gravado em 1936 em Nova Iorque [Col. Diaz-Ayala FIU].

24. Yo no le dije ná. Bolero interpretado por Grupo Victoria y Pedro Ortíz-Dávila, discos Victor $\mathrm{N}^{\mathrm{o}} 32522$, de autoria de Rafael Hernandez (El Jibarito), gravado em 1935 em Nova Iorque [Col. Diaz-Ayala FIU].

25. O que é que a bahiana tem. Samba interpretado por Carmen Miranda, discos Odeon No11710, de autoria de Dorival Caymmi, gravado em 1939 [Arquivo IEB-USP / IMS]. 
26. The peanut vendor. Rumba fox-trot interpretado por Antonio Machin, Don Azpiazu e sua orquestra Casino Havana, discos Victor No22483, de autoria de Moises Simons, gravado em 1929 (Nova Iorque) [Arquivo IEB-USP / IMS].

27. El manicero. Pregón-son interpretado por Trio Matamoros, discos Victor No46401, de autoria de Moises Simons, gravado em 1930 em Nova Iorque [Col. Diaz-Ayala FIU].

28. Tava na roda do samba. Samba interpretado por Almirante e o Bando de Tangerás, discos Victor $N^{0} 33524$, de autoria de Salvador Correira, gravado em 1932. [Arquivo IEB-USP / IMS].

29. Deixa a Nêga Pená. Samba interpretado por Almirante e o Bando de Tangerás, discos Victor No33524, de autoria de Paulo Cardoso, gravado em 1932 [Arquivo IEB-USP / IMS].

30. Morena que dorme na rede. Samba-canção interpretado por Floriano Belham e Grupo do Canhoto, discos Victor No 33951, de autoria de Roberto Martins e Wilfrido Silva, gravado em 1935 [Arquivo IEB-USP / IMS].

31. Saudades de meu barração. Samba-canção interpretado por Floriano Belham e Grupo do Canhoto, discos Victor No33951, de autoria de Ataulfo Alves, gravado em 1935 [Arquivo IEB-USP / IMS]. 